\title{
The Ethics of Treaties
}

\section{A Humean Account}

By

Steven Guy Riley

A thesis

submitted to the Victoria University of Wellington

in fulfilment of the requirements for the degree of

Doctor of Philosophy

VICTORIA UNIVERSITY OF WELLINGTON 

For Laura and the love, patience, and the many other virtues she was called upon to exemplify and which I sorely tested whilst writing this thesis. 



\section{$\underline{\text { Abstract }}$}

This thesis concerns the reasons that states have to comply with their treaty commitments. It aims to answer two questions. Firstly, what reason does signing a treaty give to a state to act in accordance with the treaty? Secondly, assuming that there is such a reason, how does entering into a treaty generate that reason?

One answer to these questions is to say that treaties are kinds of promises between states. To enter into a treaty is to make a promise and promises should be kept. But promises are a puzzling way of generating reasons for action. It is not clear how it is possible to create a reason to do something merely by communicating an intention to create a reason. So, to say that treaties are promises seems merely to transpose this puzzle from the relations between individual persons to international affairs and the relations between states.

In this thesis I endorse a view of treaty making that understands treaties as promises as the philosopher David Hume understands them. I argue that this provides a plausible account of treaty making. I suggest that the resulting view, which I label 'Treaty as Humean Promise,' provides plausible and appealing answers to the two questions mentioned above.

Treaty as Humean Promise claims that states entering treaties create self-interested reasons to comply with those treaties. They do this by invoking an independent social convention of treaty making one of the rules of which is that treaties must be kept. Continued access to this social convention is important to states. They jeopardise this continued access by violating their treaties and giving their treaty partners, and potential treaty partners, reason to withdraw future trust in them. I set this out in chapters 1 and 
2. In chapter 3 I claim that Treaty as Humean Promise can make sense of the intuition that there are moral reasons to comply with treaties. In chapter 4 I look at what Treaty as Humean Promise has to say about different types of treaty.

In chapters 5 and 6 I discuss Hume's own views on treaty making. I offer a charitable reading of some puzzling remarks by Hume from a section of $A$ Treatise of Human Nature called 'Of the laws of nations'. In doing so, I defend Hume against a number of his critics.

In the final two chapters I discuss a 'political realist' account of treaties. I distinguish between 'act' and 'rule' variants of political realism. Political realists, I suggest, should be rule realists at least about treaties. This means that they should endorse and follow the rule that treaties should be kept all else being equal. 


\section{Acknowledgements}

I would like to thank my supervisor Simon Keller for helping me in numerous ways with this project. In particular I would like to thank him for his generosity with his time and expertise. This thesis is a lot better, and certainly a great deal clearer, for that input. I would also like to thank my secondary supervisor, Ramon Das, for being available especially during the second year of my PhD when Professor Keller was overseas.

I would also like to thank my three examiners, Lisa Ellis, Chandran Kukathas, and Edwin Mares for the time, effort, and careful thought they each put into their critical comments on the original version of this thesis. All three made a number of incisive points and these have helped me realise how much more I want to say about both treaties and Hume's thoughts on international affairs. I hope one day to be able to adequately address all their many excellent comments.

Thanks must also go to my friends and colleagues amongst the postgraduate students at Victoria University of Wellington. I have gained from discussions with many of them. In particular I would like to thank Agata Orłowicz. Discussions with Agata about the similarities between some of Hume's ideas on justice (and promises) and the work of the later Wittgenstein were both enjoyable and fruitful, at least for me.

Finally, I must thank my partner Laura McCarthy. Firstly, I must thank her for reading the whole of this thesis, spotting errors I had missed, pushing me to further explain myself when I had not been sufficiently clear, and for helping me (i.e., clearing up the mess I had made) with formatting. More importantly, however, I would not have been able to write any of this without her love, support, and encouragement. Thank you.

All remaining errors, of course, are entirely my own. 



\section{CONTENTS}

INTRODUCTION............................................................................................................. 1

CHAPTER 1: FARMING, NUCLEAR DETERRENCE, CARTEL FORMATION AND THE PROBLEMS OF CREDIBLE COMMITMENT .................................................................17

CHAPTER 2: TREATY AS PROMISE AND TREATY AS HUMEAN PROMISE.

CHAPTER 3: TREATIES AND MORALITY

CHAPTER 4: CONTRACT, INTERDEPENDENT, AND NORMATIVE TREATIES 131

CHAPTER 5: WHO SHOULD COMPLY WITH A TREATY? TREATISE 3.2.11 171

CHAPTER 6: THE SHOCKING MAXIM. TREATISE 3.2.11 - 3.2.12 187

CHAPTER 7: POLITICAL REALISM. 227

CHAPTER 8: ACT AND RULE REALISM. 255

CONCLUSION 303

BIBLIOGRAPHY 310 



\section{Introduction}

\section{The story of Israel and Gibeon}

In the Book of Joshua, in the Old Testament, a treaty is made between Joshua, on behalf of the people of Israel, and the Gibeonites, Canaanite enemies of Israel. The Gibeonites trick the Israelites who are planning to smite them. Thanks to the treaty, however, the Israelites find they cannot smite the Gibeonites after all. We are told that this is because "the princes...had sworn unto them by the Lord God of Israel. And all the congregation murmured against the princes. But the princes said unto all the congregation, We have sworn unto them...now therefore we may not touch them" (Jos. 9: 18 - 19). Indeed, the community of Israel, led by Joshua, comes to the aid of the Gibeonites when they are attacked (Jos. 10:1 - 15). Nevertheless, we are told that King Saul later violates the treaty by trying to wipe out the Gibeonites (2 Sam. 21:2). A famine that afflicts Israel under a later ruler still (David) is attributed to this act of treaty violation (2 Sam. 21:1).

Treaty making and keeping were clearly considered very serious undertakings. After all, God had instructed the Israelites to smite the Canaanites (including the Gibeonites) and had instructed the Israelites not to make treaties with the Canaanites (Exodus 23:32). The Gibeonites tricked the Israelites into signing the treaty. Despite all this, the fact that a treaty was concluded was considered sufficient to give Israel a new reason, one they previously lacked, not to attack, and in fact to defend, the Gibeonites: incredibly, a reason sufficient to overrule God's own command not to make the treaty in the first place. And, as Jeremy Waldron has noted, we still sometimes talk of the 'sanctity' of treaty commitments today, even if many of us no longer share the Israelite faith in a providential God willing to act as security (Waldron 2011, 65). 
The treaty between Israel and Gibeon illustrates some important features of treaty making. Firstly, this treaty is entered by distinct political communities, Israel and Gibeon. Most modern treaties are made between states although sometimes other international organizations (such as the EU) also enter into treaties. Historically, however, treaties could be made between entities other than political communities. For example, during the English Civil War King Charles I entered into a treaty with the English parliament. For the purposes of this thesis, however, I shall have in mind international treaties between states or, at least, self-governing communities which possess the power to create law for themselves.

Secondly, the treaty is entered into by appropriately appointed representatives of the community in question. Joshua speaks on behalf of Israel. Although the people of Israel are unhappy with the treaty with the Gibeonites they are told that they must comply with it nonetheless. In this respect Israel's treaty with Gibeon differs from the covenant made between David and Jonathon (1 Sam. 20: 17). The latter covenant binds only David and Jonathon because they make it as individuals and not in any official capacity. This is unlike the treaty that Joshua enters on behalf of Israel. Likewise, modern treaties are entered by governments that claim, with varying degrees of credibility, to speak on behalf of the people of the state they represent.

Thirdly, the treaty in question is supposed to bind not only Joshua and the current people of Israel, but also future rulers, such as Saul and David, and the future population of Israel. The purported punishment for violation of the treaty, after all, is for violation under a different ruler (Saul) and the punishment for violation afflicts Israel under a different ruler still (David). That is, the treaty in question is supposed to bind future rulers and inhabitants of Israel, not just those alive when the treaty was made. Again, the same is 
true of modern treaties, although treaty makers are now normally careful to include terms of acceptable treaty termination as part of the treaty itself.

Finally, the parties to the treaty use it to exchange rights, obligations, and benefits with one another. Although this is not made very clear in the text, Israel clearly undertakes not to attack Gibeon. It also appears, as we have seen, that Israel undertakes to protect Gibeon from other enemies. And Gibeon, we can assume, makes various undertakings to Israel in return. As we shall see in chapter 4, many modern treaties are like this.

The treaty between Israel and Gibeon, then, shares a number of features with many modern treaties. ${ }^{1}$ Now, as it turns out, complying with the treaty is politically inexpedient for the rulers of Israel. The people of Israel, certainly, are unhappy with the treaty and, as I have noted above, King Saul "in his zeal to the children of Israel" later violates it (2 Sam. 21:2). Leaving aside the famine that is alleged to result from violation of the treaty we can ask, what reason does Israel have to comply with this treaty?

\section{Two questions}

In his account of treaty making David Hume offers us a seemingly straightforward answer. Hume argues that "as princes do actually form treaties among themselves, they must propose some advantage from the execution of them." It is this advantage, Hume

\footnotetext{
${ }^{1}$ It is unlikely, however, that most people would think that a treaty premised on fraud would be binding. On the other hand, it is also unlikely that most people now would think that Israel had any right to smite the Gibeonites in the first place. The Gibeonites' 'wrong' may be justified in the circumstances.
} 
suggests, which leads princes to comply with their treaties $(\mathrm{T} 3.2 .11,568)^{2}$. But if Hume means that execution of the terms of the treaty is always advantageous to the treaty maker then he seems to be wrong. Israel's treaty with Gibeon does not appear to be advantageous to Israel at all. Complying with the treaty is a burden to Israel, especially when it involves sending military aid (and Israelite lives) to the defence of Gibeon. They only keep it (as far as they do) because they fear the sanctions that would result from its violation. Now, of course, Joshua may have believed, ex ante, that some advantage would come from the execution of the treaty. That is, Joshua may have proposed, in Hume's terms, some advantage to Israel from making the treaty. But, given that he later discovered he was wrong about this, what reason do Joshua and Israel, or Saul or David, have to comply with the treaty at all? Keeping this treaty does not seem to be in the interests of Israel, its people, or its rulers.

We can distinguish two interrelated questions here:

(1) What, if any, reason does the mere fact that a treaty has been made give to the Israelites to do something that they otherwise saw no reason to do?

(2) Assuming that there is some such reason, how does entering into a treaty create such a reason?

\footnotetext{
${ }^{2}$ References to Hume's Treatise of Human Nature in the text take the following form: 'T' followed by the number of the book, then the part of the book, and then the section. This is followed by the relevant page number. References to the second Enquiry take the following form: 'EPM' followed by the number of the section and then the part (if relevant). The number following this refers to the marginal sections of the text.
} 
These are the two questions - extended to treaties in general - which I want to answer in the chapters that follow.

I approach these two questions by adopting a broadly Humean approach to treaties. Just now I noted that Hume claims that leaders (like Joshua) form treaties because they expect to gain from doing so. The immediate problem with this claim is that many treaties turn out to be burdensome. In many cases the benefits to each party to a treaty come not from their own actions but from the actions of their treaty partners (Gauthier 1970, 170 - 171). States might all agree, by way of treaty, to reduce their $\mathrm{CO} 2$ emissions. Ageneral reduction of $\mathrm{CO} 2$ emissions, let us assume, would be good for every state. But cutting $\mathrm{CO} 2$ emissions is costly. The benefit for each state of cutting emissions does not arise from its own actions (which, taken in isolation, may make only a small difference to overall CO2 levels) but, rather, from the actions of other states. But if each state acts in its own apparent interests, by not cutting $\mathrm{CO} 2$ levels, the collective result will be that the treaty will fail and CO2 levels will continue to rise.

Collective ventures, like getting all states to cut $\mathrm{CO} 2$ levels, can be very hard to initiate and maintain. Each party may worry that each other party will fail to do its part. The collective venture may never get going in the first place. In these situations there may be no way of assuring the parties who must act without knowledge of what every other party is going to do, without first giving a promise (Rawls 1971, 346 - 347; see T 3.2.5, 520 521). By giving a promise each party makes a voluntary commitment to reduce its $\mathrm{CO} 2$ levels. In so doing they appear to put themselves under an obligation to reduce $\mathrm{CO} 2$ levels even if doing so proves burdensome to them. If states can create obligations in such a way then their collective venture can be made secure enough that each can expect to gain from the cooperative actions of others. In this way, as Hume has it, princes propose some 
advantage from the execution of their promises. The kind of promises that states typically enter into are typically called treaties.

But to say that treaties are kinds of promises does not answer either of our two questions. Just as each state has reasons not to reduce its $\mathrm{CO} 2$ levels in the absence of a treaty so, too, does each state have reason to violate its treaty by not reducing $\mathrm{CO} 2$ levels. If it was true that each state could benefit more by not cutting $\mathrm{CO} 2$ levels, whatever every other state did, prior to entering the treaty, it still seems to be true that each state could benefit more by not cutting $\mathrm{CO} 2$ levels than they would by cutting them. That is, it is not clear how entering a treaty has made cutting $\mathrm{CO} 2$ levels any more valuable or desirable than it ever was.

\section{Mapping the terrain: views that see treaties as not being reason giving}

Someone might hold that treaties simply do not give states additional reasons for action. Treaties would not, then, be kinds of promises after all (unless promises are, in fact, very unlike how we normally think of them ${ }^{3}$ ).

Take, for example, International Relations scholar John Mearsheimer's discussion of the complex series of treaty arrangements that constitute NATO. During the Cold War the USA and its allies cooperated to oppose the Soviet Union and its allies. Mearsheimer argues, however, that the NATO agreements did not give the USA and its allies any additional reason to cooperate with one another. Instead, the NATO agreements were

\footnotetext{
${ }^{3}$ Patrick Atiyah, for example, considers promises to be to an admission of what the promisor ought to have done independently of the promise (see Atiyah 1981, chap. 7). We might extend this account to treaties too. Treaties would be like promises, then, but promises would be quite unlike how we normally think of them. See Raz 1982 for an incisive critique of Atiyah's account of promising.
} 
simply "a manifestation of the bipolar distribution of power in Europe during the Cold War ... it was that balance of power, not NATO per se, that provided the key to maintaining stability on the continent" (Mearsheimer 1994/95,14). In other words, the consent of states to the terms of a treaty does not, in itself, give the parties to the treaty a reason to act. What gives them a reason to act is the continuing existence of the conditions that led them to give that consent in the first place. Once those conditions disappear, and if they are not replaced by new reasons, the reasons to act as the treaty requires also disappear (see, also, Goodin 2000, 322).

My aim is not to discuss Mearsheimer's views in detail here. (I do discuss Mearsheimer and other so-called 'political realists' in more detail in chapters 7 and 8). I do, however, want to point to the fact that Mearsheimer supports his position by pointing to the fact that treaty commitments "are based on the self-interested calculations of great powers" (Mearsheimer 1994/95, 7). Because treaties are based on self-interested calculations, when they no longer serve that self-interest, states (or, at least, the "great powers") will renege on their treaty commitments. Treaties, then, cannot constrain the self-interest of states because treaties themselves are based upon and reflect the self-interested calculations of the parties to the treaty. The NATO agreements simply indicated where the self-interest of the parties lay at a particular time and place, nothing more.

That some agreements are grounded in self-interested calculations should not surprise us. In chapter 1 I introduce a version of Hume's story of two farmers who make promises to one another in order to realise self-interested ends. When we sign employment contracts, obtain a mortgage, or promise to walk the dog if our housemate does the dishes, we often employ promises to better realise our own ends. But from the mere fact that our self-interest leads us to make promises it does not follow that our promises do 
not give us some new, additional reason to do what we have promised. We typically think that they do. We say that we ought to keep our promises, at least all else being equal.

If we can find a plausible explanation of how promises can lead self-interested people to act against their apparent self-interest, we can hope to extend this account to Mearsheimer's self-interested states and their treaty agreements. The broadly Humean account of promising which I outline, and extend to treaties, in chapters 1 and 2 offers one such explanation. This explanation holds even if we accept Mearsheimer's characterization of states as self-interested.

\section{Mapping the terrain: views that see treaties as creating new moral obligations}

One approach that is very different from that of Mearsheimer claims that treaties are promises in a quite straightforward way. Just as a promise maker is typically thought to create a new moral obligation by making a promise so, too, a state might be thought to create a new moral obligation by entering a treaty. So, for example, each state that enters a treaty to reduce its $\mathrm{CO} 2$ levels thereby has a moral obligation that it previously lacked to reduce its $\mathrm{CO} 2$ levels. By entering the treaty each party transfers to each other party to the treaty the moral right to decide whether or not it must reduce its $\mathrm{CO} 2$ levels. Other parties to the treaty can demand performance from every other state. They can, if they wish, also waive or excuse the obligation of performance.

On this account states ought to comply with their treaty commitments because it is the right thing to do, morally speaking. So, for example, we do not need to ask whether treaty compliance is in the interest of the state in any way. As Fernando Teson puts it, we "assert the obligation to honor treaties because we realize that the contrary rule ... is morally intolerable" (Teson 1998, 90). For others, such as Janna Thompson, the claim that states 
have merely prudential, or self-interested, reasons to comply with their treaties must be rejected precisely because to do so is to fail to "treat treaties as promises" (Thompson $2002,6)$.

The picture of treaty making presented by Teson and Thompson (and others) draws upon an intuitively plausible picture of promising. We can, according to this picture, create a moral obligation to do something simply by successfully communicating our intention to create that moral obligation ( $\operatorname{Raz} 1977,218)$. Because it draws upon an intuitive picture of promising, I call this view in the chapters that follow 'Treaty as Promise'. I contrast it with the broadly Humean picture which I endorse and which I call 'Treaty as Humean Promise.'

I should quickly note the role that Treaty as Promise plays in the arguments of the chapters that follow. The view I identify as Treaty as Promise is rarely explicitly stated in the literature. When it is, it is often not defended at any great length. Perhaps the nearest thing to a detailed defence that we have is to be found in the natural law writers of the seventeenth and eighteenth centuries, such as Hugo Grotius, Samuel Pufendorf, and Emer de Vattel. I do draw upon these accounts but they are more complex than I can do justice to in what follows. In particular, all three writers base their account of treaty keeping (and promising) partly upon the kind of prudential concerns which I try to exclude from Treaty as Promise. Instead I try to present Treaty as Promise as a plausible, and in some ways appealing, view with elements drawn from various authors rather than as the fully worked out view of any one author. 


\section{Mapping the terrain: Treaty as Humean Promise}

Falling somewhere in between the two aforementioned pictures of treaty making is the view that I call 'Treaty as Humean Promise'. This is the account of treaty making, and keeping, that I endorse in the following chapters. Let me here give a quick statement of its main claims.

Treaty as Humean Promise claims that treaties play two important and distinct roles (see Gauthier 1990a, 124). Firstly, treaties are a device for facilitating coordination amongst states. For example, two states may want to adopt the same units of weights and measures. It does not matter much to either of them which units of weights and measures they adopt so long as they adopt the same ones. A treaty can facilitate selection of one common set of weights and measures. Once the parties have successfully coordinated there is little incentive for either to unilaterally act contrary to the treaty.

Secondly, a treaty can facilitate cooperation between states. Unlike with coordination, states often do appear to have incentives to unilaterally act contrary to treaties that aim at securing cooperation. Treaties, then, can be a device for making credible commitments. In some cases, before one state will keep its part of an agreement it will seek assurance that other states will do their part. States seeking assurance want to know that their treaty partners will not simply reassess whether or not to do their part when given that option. That is, they want to be sure that other states will not renege because doing so would enrich that state or better serve overall utility or realise some other end. The treaty is successful, and effective, insofar as it induces the belief in the parties to the treaty that other states will indeed do their part. In signalling a credible commitment a treaty can facilitate cooperation between states. 
To say that treaty making - and keeping - can fulfil valuable roles is not to give an account of how treaties can enable agents to coordinate or cooperate. For that we need an account of how treaties create reasons for action even where none existed before. Adapting Annette Baier's account of Humean promises we can note that there are four parts to the account of how treaty making can create such reasons according to Treaty as Humean Promise (see Baier 1985, 178). They are as follows:

Firstly there is some expression by an agent, on behalf of a state, of what that state binds itself to do. Typically this expression takes the form of publicly signing a formal treaty document although it may take other forms such as an exchange of notes, a telephone call, or even an email exchange. Treaty making may also involve some sort of ratification process whereby legislators or judges belonging to the signatory state consent to or otherwise implement the terms of the treaty.

Secondly, there is a social convention which recognizes certain kinds of actions (such as signing and ratifying a treaty) as the acquisition of a conventional obligation to act in certain ways. In particular there is a conventional obligation to comply with a treaty, at least all else being equal. This conventional obligation sometimes goes by the name of 'pacta sunt servanda'. The rules of the convention also grant other parties to the treaty the right to apply penalties, such as a withdrawal trust, if there is breach of that obligation.

Thirdly, and as a consequence of invoking the convention, that state is subject to a penalty for noncompliance with the rules of the convention. One way of not complying with the rules is by violating a treaty. The penalty, as suggested above, is that other states may withdraw their trust in the treaty violating state. This affects the treaty violator's reputation and makes future treaty making more difficult and costly for that state. 
Finally, this penalty provides those acting on behalf of a state with some motivating reason to avoid that penalty.

Treaties can create new reasons for action for even the most self-interested states, giving us additional reason to discount the kind of view of treaties offered by Mearsheimer, above. With the Humean account in place, however, we are in a position to explain why states may also be said to have a moral obligation to comply with their treaty commitments. That is, we do not have to limit ourselves (or our states) to self-interested concerns. It is in this way that Treaty as Humean Promise can be said to fall between the two accounts of treaty making outlined earlier.

As we shall see in chapter 3 , there is no single moral obligation that all states have to comply with all of their treaties all of the time. Some treaties ought not to be broken because doing so will undermine the peace and security of international affairs. Others ought not to be broken because others, states and other actors, will have come to rely on the treaty being kept. Some treaties ought to be kept for the simple reason that what is promised ought to be done, morally speaking, in any case. Human rights treaties are like this (see chapter 4 ).

\section{A broadly Humean account}

David Hume's comments on international affairs are often overlooked by theorists. It is common to find theoretical treatments of international affairs that draw upon the work of Thomas Hobbes, Immanuel Kant, and Hugo Grotius. But there is little work on Hume. In part this is because Hume did not write a book on international affairs, unlike Kant (Perpetual Peace) or Grotius (The Laws of War and Peace). Nor has Hume directly inspired other people's theories of international affairs in the same way that Kant can be seen in 
the work of John Rawls, Hobbes in Hans Morgenthau and the 'realist' tradition, and Grotius in the work of Hedley Bull and the so-called 'English School.'

Hume does discuss international affairs in many of his writings, from the Treatise to The History of England. He wrote a series of political essays which are mainly reactions to contemporary events and in which he discusses ideas such as the balance of power, the importance of free trade between states, national identity, and justifications for war. Both the Enquiry Concerning the Principles of Morals and the Treatise of Human Nature contain sections where Hume applies his broader theory of morality (and, in particular, justice) to international affairs.

Hume's various and scattered remarks on international affairs are rich and, in some cases, a little puzzling. I do not aim to present an overview of all of Hume's remarks in this thesis although I do note some of them, when they seem of interest, in various footnotes. ${ }^{4}$ In chapter 6 (and to a lesser extent in chapter 5) I do offer an account of Hume's views as expressed in Book 3, Part 2, Section 11 of the Treatise, called 'On the Laws of Nations.' The reason for this is that Hume applies his account of promising to treaty making between states, which is the approach I adopt and label Treaty as Humean Promise. But Hume draws a conclusion that a number of commentators have found puzzling and, for the most part, unacceptable. Hume claims that international morality is the same as

\footnotetext{
${ }^{4}$ Recent explorations of Hume's views on international affairs can be found in the work of Renee Jeffrey, who focuses on Hume's moral sentimentalism (Jeffrey 2009, 49 - 69), and Edwin van de Haar, who looks at Hume's work from the perspective of the discipline of International Relations (van de Haar 2008, 225 242). Further historical work on Hume's international theory, comparing Hume with Machiavelli this time, can be found in Frederick Whelan's Hume and Machiavelli: Political Realism and Liberal Thought
} (2004). 
morality for individual persons except that the former lacks the force possessed by the latter. In chapter 6 I aim to offer a charitable reading of Hume's argument.

Generally, however, the view I call Treaty as Humean Promise might accurately be said to be broadly Humean. That is, it takes as its inspiration Hume's theory of promising and his application of that account to treaty making (and keeping). It does not aim to give a full account of that theory. Nor does it aim to defend all of Hume's own commitments. For example, I express scepticism about Hume's claim that the moral wrong of promise (and treaty) breaking can be grounded in the harm done to the useful social convention of promising. I also do not discuss Hume's moral sentimentalist theory or his apparent commitment to the idea that the wrongness of an act is always derivative of the character (i.e., stable sentiments and dispositions) of the agent. ${ }^{5}$

The theory of promising upon which Treaty as Humean Promise is based owes as much to the more recent work of Annette Baier and Hanoch Sheinman as it does, directly, to Hume. Both Baier and Sheinman's accounts of promising are themselves inspired by Hume and so I refer, generally, to Hume's theory of promising. I try to make it clear in the text where I draw specifically upon these other authors.

The Humean theory of promising which I apply to treaties is, in many ways, a theory of promising which applies to a fairly limited class of promises. It may not turn out to be a fully satisfactory account of the value of promising in the life of individual persons. In chapter 3, in fact, I offer some considerations concerning the value of individual

\footnotetext{
${ }^{5}$ For detailed discussion of Hume's account of the 'artificial virtues', and some of the problems with this account, see Baron 1982, Gauthier 1992, and Baier 1992. For a specific discussion of Hume's theory of promising see Haakonssen 1981 (ch. 2) and Cohon 2006.
} 
autonomy which suggest that promises are more central to the sense of self held by individual persons than treaties are for political communities such as states. This is not a troubling conclusion for Treaty as Humean Promise. What is important, ultimately, is to understand how treaties create reasons for action and what kind of reasons these might be. Treaty as Humean Promise, I claim, offers us a plausible account.

Finally, I mainly discuss treaties made between states. This is not to say that other political communities cannot enter into treaties. In the past they certainly have done so, as treaties with indigenous peoples attest. When I talk about states I am using a kind of short-hand. I have in mind self-governing communities that possess the power to make laws for themselves (Thompson 2002, 5). Modern sovereign states are the obvious candidates but there are clearly many borderline, and disputed, cases such as the Palestinian territories, Taiwan, or the Turkish Republic of Northern Cyprus. My aim is to focus on the (hopefully) clear cut cases rather than the borderline ones. The account of treaties offered could then be extended to include other, more marginal cases.

Strictly speaking, states as such do not do things like sign or ratify treaties. Governments (or individual members of governments) sign treaties and, in some jurisdictions at least, legislatures (or individual members of legislatures) ratify them. In early chapters in particular I talk about states, as such, doing things like entering into treaties and having interests. This is, again, a kind of short-hand for the interests of particular groups (such as governments or citizens) within the state. In chapters 3 and 5 , in particular, the implications of accepting this short-hand are questioned. 


\section{$\underline{\text { A wide range of treaties }}$}

The central conclusion of this thesis is that there is something that links a very wide range of international agreements. What links them all is that they can be usefully understood as certain kinds of promises: Humean promises. Sometimes this may be all that there is to say about a particular treaty. In other cases, such as human rights treaties, there may a great deal more that we should say.

That there are different moral reasons to comply with different treaties at different times should not be too surprising. Treaties, after all, can, and have, been used to realise all sorts of goals in international affairs. For Gibeon and (reluctantly) Israel, a treaty was used to secure peace. Historically many treaties have had this aim and we shall come across some of them in the chapters that follow. But we will also see treaties that aim to fix the names of cheeses, secure basic human rights, found international organizations such as the UN and WTO, build dams, free up trade, cede sovereignty, and disarm nuclear stockpiles. Some treaties are important, others are trivial. It would be surprising to discover that they are all equally important from a moral point of view.

Nevertheless, there is something that all these different treaties have in common. They can all be usefully understood as kinds of promises. In particular they can all be usefully understood as promises in the sense that Hume understood promises. This is, of course, the central claim of Treaty as Humean Promise. It is the claim I aim to explore, and support, in the chapters that follow. 


\section{Chapter 1: Farming, nuclear deterrence, cartel formation and the problems of credible commitment}

The purpose of this chapter is to set the scene for the Humean theory of promising and, by extension, treaty making. It does this by introducing Hume's story of two farmers who need to find some way of cooperating with one another but where this cooperation must be asynchronous. This causes difficulties for the two farmers. The two farmers can overcome their difficulties, it seems, by promising to help one another. But promising gives rise to its own puzzles, not least how communicating an intention to create a reason to do something actually gives someone any reason to do that thing. I note that problems similar to that faced by Hume's two farmers can be found in international affairs between states. States, too, it appears, can overcome difficulties they face in successfully cooperating by making promises, typically in the form of treaties, with one another. The same puzzle, of how doing this can create reasons for action, arises for states as for farmers. I introduce two approaches that address this problem. One I label 'Treaty as Promise'. The other, insofar as it follows Hume's account, I label 'Treaty as Humean Promise'. In future chapters I endorse the latter.

\section{Introduction}

In this chapter I introduce Hume's story of two farmers. These farmers, with little kindness for one another, need to find some means of cooperating. The problem that they face is that one farmer must help the other first and then trust in the other farmer to reciprocate in kind. But, as we shall see, the other farmer appears to lack any reason to 
do so. Because of this the two farmers fail to cooperate even though they both prefer cooperation to neither helping the other. But there does appear to be one way in which they can secure mutual cooperation and that is by promising to help one another. By promising to help one another the two farmers seem to be able to commit themselves to help one another. But promise making is a strange form of commitment. It is strange because it appears to involve the creation of a reason to do something merely by successfully communicating an intention to create just such a reason. But reasons just do not seem to be the sort of things that we can create merely by intending to do so (T 3.2.5, 524; Prichard 2002, 257; Anscombe 1981, 100; and Sheinman 2008, 307 - 308).

The same kind of problem that the two farmers face is also faced by states in international affairs. As we shall see, the same kind of means for overcoming that problem is available to states as is available to the two farmers. That is, states seem to be able to commit themselves to some future action by promising to do it. The promises made by states are usually called treaties. But treaties are a strange form of commitment for the same reasons that promising is a strange form of commitment. Like promises more generally treaties seem to involve the creation of a reason to do something merely by successfully communicating an intention to create that reason.

There are two general ways of addressing the problem that promises and treaties both seem to require the creation of reasons for action where none existed previously. The first view I call 'Treaty as Promise'. It claims, roughly, that treaties should be kept because they are promises and promises should be kept because, in making a promise, an agent incurs a moral obligation to do that which is promised. The second view I shall call 'Treaty as Humean Promise'. It too claims that treaties should be kept because they are promises. But it explains the reason to keep a promise by reference to the self-interested reasons 
that an agent has not to violate an independent social convention of promising. This chapter ends, then, by setting out the basic features of these two, rival, accounts.

\section{The story}

In A Treatise of Human Nature Hume presents a story about two farmers (T 3.2.5, 520 521). For ease of reference let's call them Anita and Bob. Anita and Bob own neighbouring farms. They face a dilemma. Anita has been growing corn which will ripen ready for harvest in April. Bob has been growing corn too. But Bob's fields are in the shade and his corn will ripen ready for harvest in May. Anita cannot possibly harvest all of her corn on her own before it rots. And Bob cannot possibly harvest all of his corn on his own either.

Each farmer can choose to spend a day helping the other harvest their corn. That is, in April Bob can help Anita harvest her corn. In May, Anita can help Bob harvest his corn. If they cooperate in this way Anita and Bob can both harvest all of their corn. This would be a good result from the perspective of each farmer. Each would have as much corn, and be able to make as much money from selling that corn, as possible. Alternatively, each farmer could choose not to spend a day helping the other. Each could choose to work independently of the other. Each would incur a loss of corn, and hence income, from doing so. Let us assume that Anita and Bob want as much income as possible. Each would prefer to cooperate and help the other for one day to incurring the loss of income that would result from working independently of one another. 


\section{The general problem}

So, why does Hume think that there is a problem? The short answer is that Anita and Bob have a problem because their cooperation is asynchronous. This means that Bob must help Anita in April and then Anita must, in turn, help Bob in May if they are to cooperate. If Bob helps Anita in April then Anita will have harvested all of her corn by May without having to lift a finger to help Bob in return. Why, then, would she help Bob in May? Remember that Anita just wants to get her corn harvested and to sell it for as much money as she can. If Bob helps her and then she does not help Bob in return then Anita still gets what she wants out of the deal. Furthermore she can get on with the job of actually selling her corn without having to sacrifice a day helping Bob. And, as a bonus, she does not have to worry so much about Bob competing with her at the corn market. But if Anita can be expected to betray Bob's trust in this way then Bob would be wise not to help Anita in the first place. Even though he prefers that each spend one day helping the other to each working independently, Bob does not want to spend a day helping Anita without getting any help in return. This would be the worst possible outcome for Bob. The whole point of helping Anita, from Bob's perspective, is so that Bob can harvest all of his corn in May. In order to avoid the worst outcome, from his point of view, Bob should not help Anita in April. So, it looks like Anita and Bob should work independently of one another and simply accept the resultant loss.

This is a less than ideal outcome from Anita and Bob's perspective. ${ }^{6}$ Can Anita and Bob cooperate, avoiding the losses of working independently, despite the asynchronous

\footnotetext{
${ }^{6}$ One way of thinking about this is in terms of 'Pareto improvements'. In this example nobody (neither Anita nor Bob) prefers working independently (I) to working cooperatively (C). Bob prefers C to I. And
} 
character of their interaction? Well, let's look at this from Anita's perspective. Anita wants to influence Bob's behaviour such that Bob will help her harvest in April. But it appears that she is only going to succeed in doing this if she can get Bob to believe that she will help him in May. In order to try to achieve this Anita can commit to helping Bob in May (in return for Bob helping Anita in April). By committing herself Anita selects one option for action, helping Bob in May (if Bob helps her in April), from all of the options for action that she has (Fessler and Quintelier 2013,460). By committing to this Anita attempts to signal to Bob her intention, which she may or may not in fact have, to eliminate future alternative courses of action however attractive they might seem come May. So, in this case, Anita attempts to signal her intention to eliminate the option of not helping Bob in May. If Anita can successfully communicate this intention to Bob and if Bob believes Anita then Anita can reasonably expect to get Bob's help after all. This is because Bob will believe that Anita will help him in May so long as he helps Anita in April. Given that Bob prefers cooperation to both working independently of one another he can be expected to help Anita in April.

Anita prefers C to I. C is a Pareto improvement over I. Although Anita prefers not helping Bob, whilst Bob helps Anita, to C (let us call this state of affairs X) (and Bob prefers not helping Anita, whilst Anita helps Bob, to C (let us call this state of affairs $\mathrm{Y}$ )), Bob (Anita) prefers $\mathrm{C}$ to $\mathrm{X}(\mathrm{Y})$. X (Y) is not a Pareto improvement over C. As this exhausts the outcomes in this simple example, $\mathrm{C}$ is Pareto optimal. That is, there are no possible Pareto improvements over C (Hausman and McPherson 2006, 136 - 140).

The problem that Anita and Bob have is that, given that they are both most interested in getting all of their corn harvested and sold with minimum effort, Anita's 'best response' to whatever Bob decides to do is to not help Bob in May. And, given this, Bob's 'best response' is to not help Anita in April. Neither can do better in terms of satisfying his or her own preferences given the choice made by the other. In this instance state of affairs I will result even though there is a Pareto improvement (C) available. 
Now Anita faces a new problem. How can she commit herself in this way? In particular she needs her commitment to be credible if Bob is going to believe it and help her harvest in April. Bob needs to have good reason to believe that the commitment is genuine and that Anita will follow through with it despite future temptations not to do so. If her commitment is not credible then it will be unlikely to serve the purpose of getting Bob to help her in April. Bob is on his guard. He stands to lose out if Anita does not go through with her commitment. For example, it will not be enough for Anita to merely communicate her present intention now, in April, to help Bob in May. After all, people alter their intentions all of the time. Anita needs to demonstrate to Bob that she has some compelling reason to keep her commitment to him. Anita faces a commitment problem (see Schelling 1960, 43 - 44). How is she supposed to make, and demonstrate, a credible commitment to help Bob?

There are multiple ways in which Anita might make, and signal to Bob, this commitment. ${ }^{7}$ If she and Bob are close friends she might place a high value on helping her friends, for its own sake, leading her to commit to helping Bob in May. And she might appeal to this fact, and the shame she will feel if she does not help Bob, in order to get Bob to believe that she will help him in May. Still, the bonds of friendship are not always sufficient to lead people to actually keep their commitments. Sometimes, for example, the lure of money proves too strong. And, of course, if Anita and Bob are not friends then the appeal to friendship will be of no use to Anita. Following Hume's formulation of the case we can assume that Anita and Bob are not friends. Hume assumes that his two farmers have little

\footnotetext{
${ }^{7}$ There is a wide literature on signalling amongst humans and other animals. See, in particular, the work of Brian Skyrms, especially Evolution of the Social Contract (1996) and Signals: Evolution, Learning, and Information (2010).
} 
kindness for one another. ${ }^{8}$ Neither expects the help of the other out of generosity nor, even, as a return for a favour rendered $(\mathrm{T} 3.2 .5,520)$. Anita and Bob, at least with respect to their dealings with one another, are focussed only on getting as much of their own corn harvested as they can.

Now, imagine, instead, that Anita and Bob are members of the local Farmer's Union. One of the rules of the Farmer's Union is that when one farmer publicly states her intention to help another farmer then she must help the other farmer on pain of ostracism from the Farmer's Union. If Bob believes that ostracism from the Farmer's Union would be costly for Anita then Anita might pledge herself, according to the rules of the Farmer's Union, to help Bob (in return for Bob helping Anita) by publicly stating her intention to help Bob. In this case Anita has made a credible commitment insofar as she has made it the case that she will incur significant costs if, in May, she chooses a different course of action (Fessler and Quintellier 2013, 461). These costs are not like the internal feelings of shame that Anita claims she will feel if she lets down a friend which, in any case, she might hope to fake. They are costs imposed by the Farmer's Union upon Anita. They are costs that she will suffer even if she feels no shame at the prospect of taking Bob's help in April and not returning it in May. ${ }^{9}$

\footnotetext{
${ }^{8}$ Hume claims that people are, generally, "endow'd only with a confin'd generosity" and that if we were to "follow the natural course of our...inclinations, we shou'd perform but few actions for the advantage of others, from disinterested views; because we are naturally very limited in our kindness and affection" (T $3.2 .5,519)$.

9 The credibility of Anita's pledge according to the rules of the Farmer's Union will depend upon the costs of not helping Bob in May. These costs might be worth paying if the corresponding benefits are
} 


\section{A particular problem: credible promise making}

But, of course, an appeal to a Farmer's Union is only of use to Anita if she and Bob actually belong to a Farmer's Union. Rather than run through other ways in which Anita might try to commit herself but which may not be open to Anita (or may not be credible) let us turn to one particular means by which Anita can try to signal a credible commitment. It is the means of commitment with which Hume is concerned when he tells the story of the two farmers. Anita can promise Bob that if he helps her harvest in April she will help him harvest in May. The commitment device of promising seems to be open to Anita even if she is not friends with Bob and is not a member of the Farmer's Union, and, indeed, if she has absolutely no prior reason to help Bob. Because it does not rely upon these prior reasons to act, promising is potentially very useful.

So Anita says, "Bob, I promise to help you harvest your corn in May if you will promise to help me harvest mine in April". Has Anita credibly committed herself to helping Bob in May sufficient to get Bob to help her in April? Well, if Bob agrees, it might look like she has. But why would Bob agree to this deal just because Anita has used a certain form of words? After all, making the promise does not appear to make actually helping Bob in May any more desirable for Anita than it was before making the promise. Almost anyone

\footnotetext{
sufficiently large. Or Anita might hope to get away with breaking her pledge as a member of the Farmer's Union. Perhaps she has a stellar record as a member, whilst Bob is a new member, and she thinks her word will carry much more weight than Bob's. Finally, it is worth noting that Anita is appealing to the costs of ostracism from the Farmer's Union rather than her having made a pledge to the Farmer's Union to uphold future pledges to other farmers. If she appealed to the latter then she merely pushes her commitment problem back a step. What is it that makes her pledge to the Farmer's Union credible?
} 
can make a promise. That is the easy part. ${ }^{10}$ But what is important about the promise, at least from Bob's perspective, is keeping it and it is not yet clear why Anita has any additional reason to help Bob in May.

It certainly looks as though we can credibly commit ourselves to a course of action by promising to do it. Indeed, we do this a great deal. Like Anita and Bob most of us use promises to commit ourselves to mutually beneficial cooperative schemes. We also use them to coordinate our activities such as when we arrange to meet a friend for lunch. We use them, too, in order to commit ourselves to worthwhile relationships, say when we marry or pledge ourselves as new citizens of a state. Sometimes we simply seek to offer reassurance to those who for some reason want that assurance as when we promise our loved ones that we will drive home safely. Promising, in short, plays some role in a wide range of human relationships. Our lives would be significantly poorer if we were not able to commit ourselves in this way. ${ }^{11}$

\footnotetext{
${ }^{10}$ This way of phrasing the matter is taken from an episode of the comedy Seinfeld ('The Car Reservation'). Jerry Seinfeld is referring to car reservations rather than promises.
}

\footnotetext{
${ }^{11}$ Hume here generalises the account of the two farmers to most everyone so that, without promises, "the mutual commerce of good offices [is] in a manner lost among mankind, and every one reduc'd to his own skill and industry for his well-being and subsistence" (T 3.2.5, 520). Hume's focus is largely on commercial transactions. He does, however, recognize that promises often play a role in other human relationships such as friendship (ibid, 521). However Hume wants to distinguish between the reasons that we have to keep a promise because we have made a promise and the reasons that we might have to do that which we have promised out of, say, friendship or love. This seems to me an important distinction to make although it is one that is not always clearly made by philosophers writing about promising, some
} 
But this commitment does not appear to rely upon any prior reason that the actor has to do that which is promised. Indeed such a reason may not even exist or, even if it does, we often seek to offer some additional reason to do that which is promised, as we do when we promise our loved ones that we will drive home safely. But if promises are detached, in this way, from prior reasons to do that which is promised, how can merely making a promise signal a credible commitment to others?

Here is another way of putting the problem. By making a promise Anita seems to communicate her intention to give herself a credible reason to help Bob harvest his crops in May by the very act of communicating her intention to give herself that reason. If Anita

of whom argue that normal, that is, paradigmatic, promises gain their normative force because they promote and reinforce close relationships based upon trust (see Kimel 2003, 20, 29).

Even though some promises can help to reinforce the trust that already exists in a relationship (perhaps some marriages are like this) this does not seem to be central to promising at all. Hume's two farmers, for example, seem to make perfectly good promises to one another despite the lack of mutual trust. The promise functions in this instance as a reason to trust.

It is also the case that demanding, and making, promises in a close personal relationship based upon trust can undermine, not strengthen, the bonds of the personal relationship. If I know that my close friend wants something badly and I tell him that I will get it for him, I would most likely bemoan the lack of trust in our relationship if he then requested that I also promise to get that thing for him. By asking for a promise my friend would be indicating that he requires some additional reason to believe that I will act in his interests (see Simmonds 2004, 508 - 9). I think that we lose sight of something important about promises (and treaties) if we conflate them with other relationships within which they may play some role. This is that they (somehow) give us some reason to act that we lacked prior to making the promise (or entering into the treaty). 
communicates such an intention to Bob then Bob can still sensibly ask why he should believe that Anita has succeeded in giving herself a reason in this way. After all, reasons to do things do not seem to be the kind of things that we can bring into existence merely by intending to do so (see, for example, T 3.2.5, 524; Prichard 2002, 257; Anscombe 1981, 100; and Sheinman 2008, 307 - 308). And yet this is just what seems to happen when we make promises. So, although we each make, and rely upon, many promises throughout our lives, there is an air of mystery surrounding them. Somehow, by saying certain words and having a particular intention, we change the world in such a way that we have a reason to do something that we lacked prior to making the promise.

\section{From farmers to sovereign states}

Let us assume, for the moment, that promises do create credible commitments although it is unclear just how they do this. That is, promises represent one way in which individual people can cooperate, and do the other things we use promises for, even in circumstances where they lack a prior reason to do so. I want to now briefly indicate how Hume's story of the two farmers applies to international affairs. Hume notes that different states are, in important respects, like individual persons. ${ }^{12}$ Like Anita and Bob, for example, they often "require mutual assistance". And, again like Anita and Bob, they typically cannot always rely upon the goodwill of other states. This is a fact which leads them into "war and discord" with one another. Like Anita and Bob they have some need of a device to

\footnotetext{
${ }^{12}$ Hume notes that states are "very different" from individual persons in other respects $(\mathrm{T} 3.2 .11,567)$. I return to this, briefly, in chapter 3 and also in chapter 5 .
} 
signal credible commitment to one another. This includes a form of promising; treaty making (T 3.2.11, 567).

At an international level we typically see particular associations of persons, usually states, interacting with one another. So, for example, we see New Zealand (or, at least, its representatives) signing a treaty, threatening sanctions, or joining (perhaps leaving) international organizations such as the UN or WTO. When we see this we typically say that New Zealand is exercising its sovereignty. When we talk about sovereignty we might mean one of two things. Sovereignty might be understood as a feature of an institution, or person, within a state that is supposed to embody the overall unsupervised authority and unity of that state (see Pogge 2008, 57). So, in New Zealand we might say that parliament is sovereign. When we talk about sovereignty in this sense we are talking about internal sovereignty. But when sovereign New Zealand signs a treaty with another state its appointed representatives are understood to be acting for the whole of New Zealand in its interactions with that other state. This is external sovereignty.

I am interested in external sovereignty. Whether a state actually has some one entity which possesses internal sovereignty is an open question. In principle internal sovereignty might be dispersed among a range of different entities which nonetheless act together, expressing external sovereignty, in their international interactions. In Switzerland, for example, sovereignty is dispersed amongst the various Cantons. Nonetheless Switzerland, as such, exercises external sovereignty. So, Switzerland and 
New Zealand, for example, might make threats or promises to one another despite differing in the degree of unified, internal sovereignty that they possess. ${ }^{13}$

States are not the only agents that operate in international affairs. Multinational companies, such as Microsoft, religious organizations, such as the Catholic Church, NGOs, such as Oxfam, and collections of states, such as the EU, are all international actors. I focus, for the most part, on states in what follows. Part of the reason for this is simply that, for better or worse, and in present circumstances, states remain significant, and powerful, actors in international affairs. They typically, but not always, possess more independence from other actors and forces, and have wider capacity for action, than do other groups in international affairs (O’Neill 1986, 65 - 66). It may be desirable, for many reasons, to move beyond a world of states. For example we may want to see a more powerful UN or some other interstate institution such as a Kantian inspired federation of democratic states (Kant 1963, 93 - 102; Doyle 1983, 226; and Teson 1998, 2). ${ }^{14}$ If this is to be realised,

\footnotetext{
${ }^{13}$ Hume attacks the view that each state must necessarily have only one internal sovereign by pointing to the "disjointed, irregular government" of the Roman Republic which was also "the most active, triumphant, and illustrious commonwealth, that ever yet appeared" (Hume 1987d, 371).
}

\footnotetext{
${ }^{14}$ Kant may not have believed that the federation should be comprised of liberal democratic states. He certainly does think that "republican" governments are superior to other forms of government but republican government is not the same as democratic government (Kant 1963, 96).
}

Hume's view appears to be that what is important is not, ultimately, regime type (it being an open question whether a 'civilized monarchy' is better or worse than a republic) but, rather, the degree to which power is centralized in the sovereign. So, for example, Hume thinks that the power to create significant levels of public debt, where rulers can simply pass on the costs of repaying that debt to the populace (or 'state'), will result in “a degree of despotism, which no oriental monarchy has ever yet 
however, it will most likely be realised by states making agreements, in the form of treaties, with another. ${ }^{15}$

Tasks like ensuring that refugees are safely harboured, regulating the use of force in international warfare, and combatting devastating climate change are tasks that would be both immensely difficult for a collection of individuals to solve and which are pressing (Waldron 2011, 37). These tasks are pressing in the sense that significant harm is likely to befall individuals, and possibly groups, unless timely action is taken (ibid, 38). The responsibility for fulfilling these tasks, for better or worse, and in present circumstances, largely falls upon sovereign states. Some tasks, of course, are not so pressing. Nonetheless many of these are desirable and seem to require some degree of international cooperation and coordination. So, states agree terms for trade, migration, travel, and communication across state borders (ibid, 37). In order to address both pressing and less pressing issues states use treaties and thereby undertake

attained" because "the whole income of every individual in the state must lie entirely at the mercy of the sovereign" (Hume 1987e, 358 - 359; for a modern discussion of the power of sovereigns to run up public debts, often for their own ends, whilst passing on the burden of repaying those debts, and the role of global institutions in facilitating this, see Pogge 2002, 114 - 116).

15 Kant's essay, Perpetual Peace, for example, is comprised of various articles just like a treaty (Kant 1963, 85 -116). Kant wants governments to actually act as he suggests and so draws up a kind of ideal treaty that they might agree to. (His aim is also to say something about the proper moral relations between states irrespective of any treaty). I am interested in the question of what would make this treaty binding. How does agreeing to the nine articles, and two Addenda, give signatories any reason to actually do what they said they would do that they did not possess before signing? This, I think, is also the question that interests Hume. 
commitments to one another and, sometimes, also to individual persons. ${ }^{16}$ It is the reasons that states have to comply with their treaties, despite temptations not to do so, in which I am interested. ${ }^{17}$

\section{From farming to nuclear war, cartels, and climate change}

States, like individual persons, face commitment problems. ${ }^{18}$ That is, they face situations in which they seek to influence the expectations of some other state so that that state acts in a certain way. As with individual persons (but not Anita and Bob) it is possible that states will seek to influence the expectations of some other state solely, or mainly, for the benefit of that other state or for some third party. Often, however, one state (A) will seek to influence the expectations, and hence behaviour, of another state (B) so that B's subsequent actions are in A's interests. When states try to do this they are in a situation very much like that faced by Anita and Bob. Earlier we saw that Anita could expect to influence Bob's expectations and behaviour, in the way desired by Anita, to the extent

\footnotetext{
16 Of course treaties will not always be used to achieve noble ends like sheltering refugees. Indeed, below I offer the example of OPEC, in effect an economic cartel.
}

${ }^{17}$ In chapter 5 I discuss the fact that states require representatives to act on their behalf. In some cases it may be difficult to distinguish the purported representatives of the state from the state itself. In these kinds of cases it may seem less than plausible to suggest that 'the state' as such is entering into a treaty.

${ }^{18}$ The classic modern account of such commitment problems in international affairs can be found in Schelling 1960. It has influenced the following discussion. 
that she could credibly commit herself to helping Bob in return. ${ }^{19}$ Let us look, briefly, at two examples of commitment problems in international affairs.

\section{Example 1: North Atlantic Treaty Organization (NAT0)}

During the Cold War the USA, fearful of Soviet encroachment into Western Europe, sought to commit itself to defend Western Europe against Soviet attack by adopting a policy of Massive Deterrence. This meant that any Soviet invasion of Western Europe would be met by a nuclear response by the US against the USSR. The USA faced two commitment problems.

The first was getting its Western European allies to believe that the USA would defend it in this way (see Schelling 1966, 35). One way of doing this was to commit to doing so by means of treaty commitments, in this case NATO. As it happens the French did not think the USA's commitment was credible. They did not think that the US would risk nuclear war and the destruction of Washington in order to save Paris. And so France left NATO and developed its own nuclear forces. The USA failed to credibly commit itself to France.

The second commitment problem was a corollary of the first. If the USA could not credibly commit itself to defend its allies, because the costs of acting on its commitments, if required, were so high, then it would struggle to influence the expectations of its opponent, the USSR, too. If called upon to carry out its nuclear threat it seemed as though the USA would have no reason to do so.

\footnotetext{
${ }^{19}$ Or credibly commit to doing Bob some harm if he does not help her harvest her crops. Anita would, in this instance, be threatening Bob.
} 


\section{Example 2: Organization of Petroleum Exporting Countries (OPEC)}

Imagine that Anita and Bob cooperate and harvest all of their corn. They each now hold a substantial quantity of corn ready to go to market. They now face a new opportunity to cooperate as well incentives not to cooperate. This new interaction is reflected in international affairs with the example of OPEC countries.

Here is the new situation faced by Anita and Bob. It is adapted from a case discussed by Joseph Heath (2001, 104 - 105). Imagine that if both Bob and Anita charge $\$ 10$ per bushel of corn then they can expect buyers to buy 100 bushels (most likely 50 from Anita and 50 from Bob). If one charges $\$ 8$ per bushel instead, then he or she can expect buyers to buy 120 bushels. (If both drop their price then buyers will buy 60 from each). Imagine that, either way, their costs are $\$ 5$ per bushel. If Anita lowers her prices and Bob does not then she will make a profit of $\$ 360$ (and Bob will make $\$ 0$ ). If neither lowers their prices then each will make a profit of $\$ 250$. If both lower their prices then each will make a profit of \$180. If only Bob lowers his prices then Anita makes $\$ 0$ (and Bob makes $\$ 360$ ) (see Heath $2001,104-105)$

From the perspective of Anita and Bob this looks similar to the problem that they faced in cooperating to harvest their corn. If they can credibly commit to price collusion in order to keep corn prices at $\$ 10$ per bushel then they can avoid both lowering their prices (and receiving only $\$ 180$ each). As corn buyers the rest of us will hope that at least one of 
them will attempt to get an advantage by breaking the commitment and lowering prices. Promises are not always used to achieve noble ends. ${ }^{20}$

Anita and Bob's new, collusive, commitment problem is mirrored in international affairs. OPEC is an international organization and economic cartel. It is comprised of 12 oil producing states that attempt to set the world price of oil in favour of the members of the organization. This is achieved through manipulation of production quotas. So, for example, if the cartel members want to raise the price of oil they cooperate on decreasing the production of oil. But there are opportunities for individual members to benefit if every other member decreases oil production, pushing up oil prices, whilst they continue to secretly produce and sell oil at the previous rate. OPEC states thus face a problem in making credible commitments to coordinate in pushing up oil prices.

\footnotetext{
${ }^{20}$ We may, of course, think that a promise to realise some independently immoral end is not a genuine promise. So, if I 'promise' to kill your landlord I will not, on this view, really have made a genuine promise at all. I am not bound to kill your landlord because I ought not to kill your landlord in any case.
}

It is a difficult question as to whether or not immoral promises are genuine promises. I may, for example, be able to make a perfectly good promise to kill your landlord but, on the balance of reasons, lack sufficient reason to keep the promise. I may owe you something, say an apology, for not keeping the promise. That I entered into such a promise which (on the balance of reasons) I ought not to keep may also reflect badly upon me and my credibility (and competence) as a promisor. That is, it may reflect negatively upon my reputation.

Colluding to fix corn (or oil) prices, in any case, does not seem to be as clearly immoral as promising to kill your landlord. 


\section{Other examples}

Other examples of commitment problems in international affairs are not difficult to find. When Ukraine agreed to give up its share of the nuclear arsenal in exchange for respect for its international borders how could it be sure that the other parties to the agreement would continue to respect it in the future? How can states successfully cooperate to substantially limit dangerous greenhouse gas emissions? New Zealand, for example, has agreed to reduce its greenhouse gas emissions by 2020 just so long as other "developed countries make comparable efforts to those of New Zealand"(Barrett 2012, 31). But so long as other developed countries premise their efforts on similar provisos, even states wanting to cooperate on averting climate change face significant commitment problems in doing so. Remember that Anita and Bob preferred cooperation to each attempting to harvest their corn on their own. Nevertheless because Bob wanted to avoid the worst outcome of all, from his perspective, he was unwilling to help Anita in April. Despite both preferring cooperation to working independently, Anita and Bob ended up working independently. States sometimes face much the same problems.

\section{Treaties and other commitment devices}

There are a number of ways in which states can signal their commitment to other states in an effort to alter the expectations, and behaviour, of those others. These mirror the ways in which Anita and Bob can try to signal their commitments to one another. Just as Anita could, under certain circumstances, appeal to her friendship with Bob, and the psychological costs of shame she would feel on betraying that friendship, so too might a state commit itself by invoking some kind of close relationship with another state. The USA faced with British, rather than French, scepticism about its willingness to defend 
Western Europe might appeal to the so-called 'special relationship' between the two states to signal its commitment to Britain's defence. ${ }^{21}$ Still, it can be difficult for other parties to accurately ascertain the strength of such a commitment. And to the extent that such a commitment relies upon the psychological dispositions of particular individuals, such as decision-makers, within states, the force of the commitment will alter as particular decision-makers leave and enter office. For example, British Prime Minister Edward Heath did not place much importance upon the special relationship with the USA, preferring to move Britain closer to Europe. The force of British commitments to the USA which were premised upon that special relationship was subsequently weakened. Finally, of course, states may have no such special relationship, or anything like it, to fall back upon.

Anita, we saw, might have belonged to the Farmer's Union, membership of which gave her some reason to help Bob if Bob helped her. Her commitment to help Bob, in exchange for Bob's help, would be credible insofar as the likely costs that would be incurred through punishment (e.g., ostracism) by the organization would outweigh the gains to Anita of taking Bob's help and not reciprocating.

States, too, are often members of international organizations. NATO and OPEC are two such organizations that we have already encountered. However with regard to both NATO and OPEC the commitment problem arose within the organization itself. That is, it is the commitment of the USA to NATO and the individual members of OPEC to the collective decisions of OPEC itself that are open to doubt. Still, if the costs of being

\footnotetext{
${ }^{21}$ This supposed 'special relationship' was, in fact, a further reason for France to pull out of NATO (see Wenger, Nuenlist, and, Locher, 2007).
} 
ostracised from the organization are high enough, as is arguably the case with the $\mathrm{EU},{ }^{22}$ then commitments that carry the cost of being ostracised from that organization, if broken, can be credible just so long as other members of the organization can be expected to enforce the ostracism. But such enforcement is itself costly and other members of the organization may be reluctant to bear those costs (Brennan and Pettit 2004, 270 - 274).

Anita and Bob apparently had at their disposal another means of committing themselves. They made a promise to each other. It is a strange form of commitment because it involves creating a reason to do something by successfully communicating an intention to create just such a reason. States, which also face commitment problems, have at their disposal a similar commitment device in the form of treaties. Just as Anita and Bob might hope to successfully cooperate by making promises so, too, can states attempt to cooperate with one another by means of treaty making. Promises and treaties are widely held to be closely and conceptually related (Sheinman 2011c, 3). But insofar as this is the case, the ability of both treaties and promises to credibly commit actors stands in need of explanation. It is to this task that we must now turn.

${ }^{22}$ See, for example, Springford, Tilford, and Whyte (2014). 


\section{Social Conventions ${ }^{23}$}

Here is how Anita's promise to Bob might go. Anita may employ a certain form of words to communicate her intention to give herself a reason to help Bob harvest his crops in May (if Bob helps Anita harvest her crops in April). So, Anita might say "Bob, I promise to help you harvest your crops in May (if you help me harvest my crops in April)". Bob: “Agreed!"

In doing this Anita and Bob have made use of certain shared social conventions. For example, both Anita and Bob may understand that, upon saying the words "I promise to" followed by a description of some action, in certain circumstances, Anita has communicated an intention to give herself a reason to do whatever it is that is promised. Anita has made use of certain words that indicate to both parties that a commitment has been made. These conventional features may differ in different societies or there may be other conventional ways in which Anita could communicate a promise to Bob.

A social convention of promising may not merely consist of rules for the use of language (Sheinman 2008, 299). When Anita makes a promise to Bob she may be invoking a social convention, or rule, that, having made a promise to do $x, x$ must be performed all else being equal. This social rule may not be written down anywhere (although it might be). And it need not be a rule that anyone has explicitly agreed to. Instead what is notable

\footnotetext{
${ }^{23}$ Other than Hume's account of social conventions (see, for example, T 3.2.2, 489 - 492), the classic account of conventions is given by David Lewis (who acknowledges his debt to Hume) (see Lewis 1969, 42 - 51). A more recent account of conventions, which I draw upon in chapter 6 , has been offered by Andrei Marmor (Marmor 2009, 2 - 19). See, also, Russell Hardin's discussion of Hume on social conventions $(2007,81-104)$ and that offered by David Gauthier (1990b, 47 - 52).
} 
about social conventions is that they are a regularity of behaviour that is understood to be binding by members of the group whose convention it is. ${ }^{24}$ If Anita makes a promise, and Bob knows that Anita is aware of the social rule that promises must be kept (and Anita knows that Bobs knows this, and Bob knows that Anita knows that Bob knows this, and so on), then Bob will have some reason, but maybe not a decisive reason, to expect Anita to keep her promise.

A social convention of promising can be compared with other social conventions. Take, for example, the convention that, in New Zealand, drivers drive on the left hand side of the road. Although this is a legal rule, in New Zealand, if, for some reason, the law was to be rescinded and not replaced, drivers would still have reason to drive upon the left hand side of the road. The rule is a social rule insofar as it is a widely recognized regularity of behaviour amongst drivers in New Zealand. And part of the reason that each driver has to continue driving on the left is the fact that (most) everyone else complies with the social convention. If they did not, and most others started driving on the right, then each would instead have reason to drive on the right instead. In fact, it does not much matter whether drivers drive on the left (as in New Zealand) or the right (as in France) so long as they all do the same (Hardin 2007, 88).

The social convention of driving on the left determines how drivers in New Zealand behave, just as a social rule that promises must be kept will determine how promisors behave. Of course, the social convention that drivers will drive on the left is a nice and

\footnotetext{
${ }^{24}$ A social convention is a regularity of behaviour amongst a group of agents in some situation(s) where part of the reason that most of those agents conform to the regularity of behaviour in that situation is their awareness that most other agents conform and that most other agents expect most agents to conform. See Lewis $(1969,78)$ for a more precise account.
} 
neat one in ways that the social convention of promising is not. In particular Anita, for example, has no reason to drive on the right in New Zealand assuming that she does not want to crash her car. But, as we have seen, she does appear to have some reason to break her promise. So, noting that there is a social convention of promising does not, itself, explain why Anita will follow the rules of that convention on each occasion.

One reason that Anita would have to follow the rules of the social convention of promising is if violations of those rules would be met with sanctions or disapproval by others. If Anita is foolish enough to drive on the right hand side of the road in New Zealand, the rest of us may impose some sanction upon her. For example, we might take her car keys off her (or get the magistrate to do it for us if that is an option) or, if that is not an option, for example if no-one wants to bear the costs associated with trying to take Anita's car keys off her, we may express our disapproval in other ways. Likewise a failure to keep a promise, contrary to the social rules of promising, may be met by sanctions (for example, not having her promises accepted in the future) and disapproval (Sheinman 2008 - 302; T 3.2.5, 522).

In much the same way there are social rules of treaty making. Some of these rules will be like the particular linguistic rules by which Anita made her promise to Bob in the sense that they fix, for the society of states, commonly understood ways of making a promise. So, for example, there may be a social rule that a state has entered into a treaty once it has been definitively signed ${ }^{25}$ by a duly appointed representative of that state (Aust 2007, 96 -97). But there may be other conventional ways of entering into a treaty too such as,

\footnotetext{
${ }^{25} \mathrm{~A}$ 'definitive signature' is to be opposed to a 'simple signature'. The latter is subject to further ratification whilst the former is not. So US President Bill Clinton gave a simple signature to the Rome Statute (1998). As this was never ratified by the Senate, he did not definitively sign it.
} 
for example, an oral agreement between ministers. ${ }^{26}$ Some of these rules will concern the behaviour of the state, just as the social rule that promises must be kept concerns the behaviour of individual persons. So, for example, there is a widely known, and accepted, social rule that goes by the Latin name of pacta sunt servanda, which means simply that promises made must be kept, all else being equal. As with the example of the rules of the road the social convention of treaty making may also be made a matter of positive law. This has, in fact, been done in the form of a treaty about treaties, the Vienna Convention on the Law of Treaties (1969). Although the Vienna Convention has coordinated some expectations amongst states it, itself, has not created the social rule that treaties must be kept.

That most, perhaps all, societies, including the society of states, have such social conventions of promising is not widely disputed. What is disputed, however, is what role the social convention of promising plays in allowing agents to create reasons for action where none existed prior to the promise being made. There are, roughly, two approaches. We can call them the non-conventionalist and conventionalist accounts of promising.

\section{8a. Non-conventionalism}

The non-conventionalist account of promising does not deny that social conventions are often useful ways of making promises. Without widely understood social conventions of promising there would be a great deal more scope for confusion and misunderstanding. It would be far more difficult to make promises. But it would not be impossible to make

\footnotetext{
${ }^{26}$ A dispute between Denmark and Finland was settled in 1992 by a telephone conversation between the Danish and Finnish Prime Ministers (Aust 2007, 9).
} 
promises. This is because we can commit ourselves by means of making a promise, in principle at least, without the aid of a social convention at all. When we make a promise what is important, on this view, is that we create a moral obligation to do that which is promised.

Proponents of non-conventionalist accounts of promising differ as to how it is possible to create a moral obligation by communicating our intention to create that moral obligation. Some, such as John Locke and, more recently, Joseph Raz and Seana Shiffrin, posit a kind of inherent normative power that we have to alter our obligations by a suitable act of will (Locke 1746, bk, 2, chap 2, para. 14; Raz 1972, 96 - 98: and Shiffrin 2008, 502 - 510). Other accounts, notably that of T.M. Scanlon, ground the moral obligation to keep a promise in the expectations generated in the promisee as a result of the promise being made (Scanlon 1998, 295 - 327). Such expectations, on this view, can be intentionally created even in the absence of a social convention.

We can apply the non-conventionalist approach to promising to treaty making too. Marshall Cohen, for example, tells us that he endorses Scanlon's view of promises and applies this to the relations between states (Cohen 1984, 333). More recently Fernando Teson has grounded the moral obligation to keep a treaty in Kant's Categorical Imperative (Teson 1998, 101 n.66). We can sum this view up as follows. I shall call it Treaty as Promise and I say more about it in the next chapter. 


\section{Treaty as Promise}

A treaty should be kept because it is a promise. And promises should be kept because the promisor has undertaken a moral obligation to do that which is promised. The moral obligation is created by means of communicating to the promisee an intention to undertake just such an obligation. If the promisor fails to do that which is promised then the promisor has done something morally wrong.

The promise will motivate the promisor to do that which is promised insofar as the promisor feels moved, to some extent, to act from a sense of duty.

A promise, and hence a treaty, can be made even in the absence of a social convention of promising.

Treaty as Promise, then, answers the problem raised earlier about how making a promise can give an agent a reason to act that they lacked prior to making the promise. It does this not by pointing to a social convention of promising but by pointing to a moral obligation to keep a promise.

\section{8b. Conventionalism}

The non-conventionalist account of promising differs from the conventionalist account. In particular the conventionalist account of promising denies that promises can be made, even in principle, without invoking some social convention of promising. Acts of promise making, and keeping, are, on this view, essentially conventional acts. They are essentially conventional in the sense that we cannot even engage in the activity of promising without using a pre-existing social convention of promising to do so (see T3.2.5, 519; Rawls 1955, 24 - 29; Sheinman 2008, 307 - 308; and Nardin 1983, 15). 
Take, for example, a case developed by Scanlon and discussed by Sheinman. Scanlon, as we have seen, advocates a non-conventionalist account of promising. Scanlon asks us to imagine two hunters, A and B, who are on opposite banks of a river. A has mistakenly thrown his spear which is now on B's side of the river. B has mistakenly thrown his boomerang, which is now on A's side of the river. A and B cannot cross the river. They are perfect strangers and do not speak the same language. And they do not share a social convention of promising. Despite this A gets B to believe that if B returns the spear A will return the boomerang. Although B returns the spear, A does not return the boomerang. Scanlon's view is that A has committed the same kind of wrong as that involved in breaking a promise (Scanlon 1998, 297; see, also, Sheinman 2008, 310).

Someone committed to a conventionalist account of promising will question whether the situation described by Scanlon is possible. For example, Hanoch Sheinman offers the following line of reasoning. It is unclear how A can get B to have the requisite belief that A will return the boomerang if B first returns the spear. B lacks evidence that A has any intention to return the boomerang if B returns the spear. Should A have the relevant intention at T1, moreover, B lacks evidence that A will not just decide at T2 to keep the spear and the boomerang after all. What B does know is that A has some reason to keep both the spear and the boomerang. B does not know what social rules A may or may not be committed to or whether A will incur any costs at all in failing to return the boomerang. If $B$ does not return the spear then A does not obviously do anything morally wrong in not returning the boomerang. Still less does A break a promise to B (Sheinman 2008, 310 $-311)$.

On the conventionalist account A can make a promise to B only if they share some social convention of promising with one another. In particular A can invoke the social 
convention with its rule that promises must be kept. In so doing A, on the conventionalist account, creates a reason to return the boomerang (if B returns the spear). As was the case with the non-conventionalist account, different conventionalists offer different accounts of what this reason might be. According to the Humean account by making a promise A thereby creates a self-interested reason to return the boomerang (if B returns the spear). We have already seen how this self-interested reason might be accounted for when I noted, earlier, that sanctions and disapproval will often attach to those who violate social rules. I return to this in chapter 2 .

This conventionalist picture of promising can also be applied to treaty making. Indeed, Hume directly applies his conventionalist theory of promising to international affairs ( $\mathrm{T}$ 3.2.11). We can sum this view up as follows. I shall call it Treaty as Humean Promise and I say more about it in the next chapter.

\section{Treaty as Humean Promise}

A treaty should be kept because it is a (Humean) promise. And promises should be kept because keeping promises is in the self-interest of the promisor. Keeping a promise is in the self-interest of the promisor in part because failing to keep the promise is contrary to the rules of a social convention of promising and because acting contrary to the rules of a social convention of promising is contrary to the self-interest of the promisor. By making a promise a promisor thereby creates a self-interested reason to keep the promise, which the promisor does by successfully communicating to the promisee her intention to give herself just such a reason.

The reason she creates is motivating insofar as the promisor feels moved, to some extent, to keep the promise by recognition of that self-interested reason (Sheinman 2008, 297). 
A promise, and hence a treaty, requires the existence of an independent social convention of promising if it is to be made at all.

Treaty as Humean Promise, then, answers the question raised earlier about how making a promise can give an agent a reason to act that they lacked prior to making the promise. It does this by pointing to the existence of a social convention of promising, by means of which a promisor can commit herself, and then by explaining the reason the promisor has to actually follow the convention, and keep the promise, in terms of the promisor's self-interest.

\section{Conclusion}

Hume introduces a story about two farmers to illustrate some of the problems that any complete account of promising must find some way of dealing with. As we saw, one of our two farmers, Anita, wanted to find a way of giving herself a reason to help the other, Bob, even though she lacked any prior reason to help him. She wanted to do this in order to get Bob to alter his expectations regarding her future behaviour and, in particular, to get Bob to help her harvest her corn before she helped harvest his. Bob, being wary and concerned about the prospect of helping Anita and receiving no help in return, was looking for a credible commitment from Anita. One way that looks to be open to Anita is to make Bob a promise. But this left us with a puzzle. How is that merely making a promise can give Anita, who otherwise lacks a reason to help Bob, a reason to help Bob?

Similar problems of making credible commitments face states in international affairs. I gave the example of the USA's NATO commitments and also the economic cartel of OPEC. Where the same problem exists we can look to find the same solution. Just as Anita and Bob can make promises to one another so, too, states can enter into treaties with one 
another. These treaties are ways in which states can, apparently, give themselves reasons to act which they previously lacked or which they think they might lack in the future. But appealing to treaties as a credible commitment device leaves us with the same puzzle as did Anita and Bob's promise. How is that merely signing a treaty can give a state, which otherwise lacks a reason, a reason to do that which is promised?

I finished with two possible answers. The first I called Treaty as Promise. According to this view, to make a promise just is to create, somehow, a moral obligation to do that which is promised. If Anita makes a promise to help Bob then she has a moral obligation to help Bob. Insofar as Bob believes that Anita takes her moral obligations seriously he will be reassured that she will help him if he helps her first. A treaty should be kept, on this view, because it is a promise. And, as we have seen, promises should be kept because there is a moral obligation to do so. There is no need to appeal to any pre-existing social convention of promising to explain this.

The second answer I called Treaty as Humean Promise. According to this view, social conventions, that is, regularities of behaviour amongst members of a group that are treated as binding, are essential to making promises. To make a promise is to invoke the rules of a social convention of promising including the rule that promises must be kept. To violate the social convention, by breaking the promise, is to leave oneself open to social sanction and disapproval. This, it is claimed, is not in the self-interest of the promisor and hence she has reason to keep the promise that she lacked prior to making it. If Anita makes a promise to Bob then she gives herself a self-interested reason to help Bob. Insofar as Bob believes that Anita is aware of this self-interested reason and is motivated to act by recognition of that reason, he will be reassured that she will help him if he helps 
her first. A treaty should be kept, on this view, because it is a (Humean) promise. And promises should be kept because it is in the self-interest of the promisor to do so.

So, we have two general ways of accounting for the ability of promises, and by extension treaties, to create credible commitments. Having got this far we must now turn to look at these two accounts in more detail. I turn to this task in the next chapter. 


\section{Chapter 2: Treaty as Promise and Treaty as Humean Promise}

In the previous chapter I introduced a version of Hume's story of two farmers, now called Anita and Bob, and noted how despite cooperation being in the interests of each they struggled to actually cooperate with one another. Focusing on Anita, in particular, I noted that she faces the problem of getting Bob to change his expectations and behaviour so that he will help her. This is the commitment problem faced by Anita and Bob. And, I noted, it applies to the interactions of states too. I offered a couple of examples. In this chapter we will come across some more. I expand upon the two accounts of treaty making, 'Treaty as Promise' and 'Treaty as Humean Promise', introduced at the end of the previous chapter. I identify some strengths of each theory but, ultimately, endorse 'Treaty as Humean Promise'. I note that one possible point of weakness of 'Treaty as Humean Promise' is that it does not appear to make treaty keeping a matter of moral concern.

\section{Introduction}

In the previous chapter I introduced different ways of making a credible commitment. My focus was on one: promising. Anita and Bob could promise to help one another. And, by extension, states facing similar commitment problems can make promises to one another. After all, people make promises all the time. And so, it appears, do states. Since 1945 over 50,000 treaties have been registered with the United Nations (Aust 2007, 1). As Hume notes, such treaties "would only be so much waste of parchment, if they were not found by experience to have some influence and authority" (EPM 4, 206, emphasis in original). 
But it is unclear where this "influence and authority" might come from. I sketched two different ways of understanding treaties which I called Treaty as Promise and Treaty as Humean Promise. It is time to look at them in more detail and to see whether they can help us to discover how promises, and treaties, can help agents create credible commitments to one another and thus overcome their commitment problems.

I endorse Treaty as Humean Promise. In what follows I suggest that Treaty as Promise struggles to explain how treaties (or promises) can be used to give credible commitments to others. From the promisee's perspective, that is, from the perspective of Bob, say, or France, it is difficult to assess the reliability of the promisor's commitment. This is because Treaty as Promise struggles to give a convincing account of the motivation to keep promises (and hence treaties). I then present Treaty as Humean Promise in more detail and argue that it does a better job of explaining how promises and treaties can be used to create credible commitments.

\section{Treaty as Promise}

Here I present the view I call Treaty as Promise. Perhaps the best known advocates of this view are the $17^{\text {th }}$ and $18^{\text {th }}$ century theorists of natural law, such as Hugo Grotius, Samuel Pufendorf, and Emer de Vattel. These thinkers each adopted some version of what is often called a 'normative power' view of promising (Habib 2014, sec. 5.1). According to this view agents (such as individual persons and states) are able to alter their normative situation (by, for example, creating obligations and reasons or conferring rights) by performing acts intended to achieve just such an alteration. Promises and treaties, on this view, derive their binding force from the intentions of those making the promise. It is this view that Hume has in mind when he says that it is "entirely conformable to our common 
ways of thinking and of expressing ourselves, when we say that we are bound by our own consent, and that the obligation arises from our mere will and pleasure" $(\mathrm{T} 3.2 .5,517)$. Hume, however, rejects this view.

What explains this power, for the natural law defenders of Treaty as Promise, is, unsurprisingly, some feature of the natural law itself. For Grotius, for example, the obligation "to perform Promises is a Duty arising from the Nature of immutable Justice, which as it is in GOD, so it is in some Measure common to all such as have the Use of Reason" (Grotius 2005, bk. 2, chap. 11, sec. 4). ${ }^{27}$ He tells us that reason requires promise (and treaty) keeping because "nothing is so agreeable to human Fidelity, as to observe whatsoever has been mutually agreed upon...the free Consent of the Promisor, is said to be agreeable to natural equity" (ibid, bk. 2, chap. 11, sec. 1.4). Likewise Pufendorf tells us that natural law commands that we enter into, and keep, our promises in order to escape the state of nature (Pufendorf 2005bk. 1, chap. 7, sec.7). Often such arguments were supported further by appeal to God but, in principle, the requirements of the natural law are discoverable and binding absent divine sanction. Both Grotius and Pufendorf, for example, point to the desirability that having such a normative power has for agents such as ourselves.

Modern advocates of the normative power view likewise claim that the ability that agents have to change their normative situation by communicating an intention to change their normative situation is grounded in, or justified by, the desirability of those agents

\footnotetext{
${ }^{27}$ This is also the view of Locke who explicitly equates the "Law of Nature" with "Reason" (Locke 1746, bk. 2,chap. 2, para 6).
} 
possessing that ability. ${ }^{28}$ One influential modern version of this view, for example, argues that a moral rule requiring promise keeping is justified by the desirability of being able to enter into, and strengthen, special relationships with others (Raz 1972, 101; Kimel 2003, 29; Shiffrin 2008, 502 - 510).

Unlike the natural law theorists, most modern proponents of the normative powers account of promising have not explicitly extended their account of promising to treaty making amongst states. Part of the reason for this is the result of some uneasiness at the prospect of extending the interest that individual persons have in developing close, meaningful relationships with others to large-scale institutions like states. The value of having the normative power to make promises may, then, require a slightly different explanation when the power is held by some institution, such as a state (Raz 2011, 6). I see no reason to think that such an explanation could not be offered. Our two farmers, after all, were not interested in strengthening or even securing a meaningful, special relationship with one another (other than in terms of their labour transaction). And yet it seems clear that it is desirable even for agents like this to have the power to make promises to one another. The same, I suggested, is true of states. In any case what is most important, on the normative powers view, is that agents, whether people or states, are able to create moral obligations to do something by communicating their intention to create those moral obligations. It is such a power that lies at the heart of Treaty as Promise.

\footnotetext{
${ }^{28}$ So, for example, Joseph Raz tells us that "promises are binding because it is desirable to make it possible for people to bind themselves...if they so wish" (Raz 1972, 101).
} 
Not all of those who argue that treaties are kinds of promises understand themselves as being in the tradition of the natural law theorists. For some, like Fernando Teson, the moral obligation to comply with a treaty can be best explained by an application of Kant's Categorical Imperative regarding the moral wrong of lying promises (Teson 1998, 90, 101 n.66). Janna Thompson, on the other hand, argues that it would be hypocritical, and morally wrong, to hold our successors bound to comply with any treaties that we enter into whilst refusing, ourselves, to honour the treaty commitments of our predecessors (whether or not we actually do make any treaties) (Thompson 2002, 15 -18). Others are less clear about the moral theory underpinning their account of treaty making and keeping. Marshall Cohen, for example, cites both John Locke and T.M. Scanlon in support of his view that international promises are binding (Cohen 1984, 333). Locke holds something like the view I attributed to Grotius, above. Scanlon, on the other hand, locates the moral obligation to keep a promise in the expectations of the promisee, rather than the exercise of some inherent normative power, although, to be sure, the promisor must "voluntarily and intentionally" lead the promisee to have that expectation (Scanlon 1998, 304). So, the view that I am calling Treaty as Promise can perhaps best be thought of a family of views that share certain, but not all, features in common. I think that we can identify four such central features of Treaty as Promise. I shall say a little about each.

\section{2a. Promises and treaties create moral obligations}

We make promises, and states enter into treaties, for all kinds of reasons. I have focused on one kind of reason so far. Promises and treaties are sometimes, perhaps often, made in order to commit the promisor to some future course of action in order to realise some 
end that the promisor has such as getting the promisee to act in the promisor's interest. ${ }^{29}$ That is, the selected option for action, say helping Bob harvest his corn in May, is chosen because it is instrumentally superior to other ways of getting Bob to harvest the promisor's corn in April. The problem, of course, is that the promisor may in fact lack a reason to uphold the commitment once it comes time to perform (that is, once the instrumental purpose of the promise has been served or is, for some other reason, no longer desired by, or in the interests of, the promisor).

What Treaty as Promise suggests is that when we commit ourselves to some course of action by means of making a promise, or signing a treaty, we thereby make performing that action morally obligatory. And having a moral obligation gives the promisor an especially stringent kind of a reason to act. In the words of Grotius, keeping the promise is a matter of "moral necessity" (Grotius 2005, bk. 2, chap. 11, sec. 4.3). So, although we might make the promise in order simply to get something that we want, once we have made the promise the consideration of reasons for and against doing what we have promised to do are, except perhaps in certain extreme circumstances, irrelevant. Having made a promise the promised course of action is simply morally required of the promisor.

\section{$\underline{2 b}$. These obligations are self-imposed}

The obligation to do that which is promised is an obligation that is imposed upon the promisor. However, unlike obligations imposed by God, say, or society, the obligations that are imposed upon the promisor are self-imposed. This should not be understood to mean that the obligation is merely avoidable (Pratt 2007, 538). I can avoid the obligation

\footnotetext{
29 Or, at least, the promisor's perceived interest.
} 
that I have to care for my children by not having any children, but my obligation to care for my children is not, for that reason, self-imposed. Rather, by calling an obligation selfimposed, we mean that the intention to create for ourselves an obligation to act in a certain way, by means of making a promise, plays some role in justifying our actually having that obligation (ibid, 535 - 539). I have an obligation to look after my children whether I intended to have children, or the obligation, or not. ${ }^{30}$ It is in this sense that the obligation is avoidable but not self-imposed. But I do not have an obligation to take my children to Disney World unless I communicate to them my intention to incur an obligation to take them to Disney World. I can do this by making them a promise. So whilst the obligation to care for my children is not self-imposed, though it is avoidable, my obligation to take them to Disney World is self-imposed. I would not have it were it not for my promise.

We can apply this line of thought to treaties too. We might hold, for example, that Australia has a moral obligation to explain, apologize for, and perhaps compensate, the wrongful theft of aboriginal land despite there being no treaty promising not to steal that land. If this is so, and insofar as it is guilty of the same kind of acts, then New Zealand would also have the same kind of obligation to explain, apologize for, and perhaps compensate, the wrongful theft of Māori land. But in New Zealand there is also a treaty whereby one party promised not to steal Māori land (or allow it to be stolen). ${ }^{31}$ According

\footnotetext{
${ }^{30}$ I have this obligation to look after my children whether or not I intended to have children in order to fulfil my obligations to my children. That is, my intentions do not play a justificatory role in my having the obligation (although they do play a causal role).

${ }^{31}$ I refer to the Treaty of Waitangi (1840). This is a very much simplified account of what the treaty actually promises.
} 
to Treaty as Promise, Australia has violated one obligation not to steal land. New Zealand has violated this obligation and has violated a self-imposed obligation. New Zealand has done (at least) two things wrong. It has stolen land and broken a (self-imposed) promise.

\section{$\underline{2 c . \text { Social conventions are useful but not essential }}$}

Now, making a promise can be greatly facilitated by the existence of certain shared conventional rules (Dworkin 2011, 309). I have already noted that this might take the form of a certain form of words understood by both promisor and promisee to signal that a promise is being made. Without this there is the potential for confusion and mutual misunderstanding. Anita might perform an act, such as driving around her farm fifteen times on her tractor, which she believes communicates to Bob her intention to undertake an obligation to help Bob in May. If Bob is not aware that Anita's act of driving fifteen times around her farm on her tractor is supposed to communicate an intention to undertake an obligation to Bob then Bob will not alter his expectations of Anita's behaviour. He will not then help her in April. Alternatively, Anita might understand Bob waving to her as she drives around her field as communication of his intention to undertake an obligation to help her in April when, in fact, Bob lacks any such intention and is merely being polite.

Such miscommunication happens in international affairs too. In 1919, for example, Denmark believed that Norway had incurred an obligation to recognize Danish sovereignty over Greenland in return for Danish recognition of Norwegian sovereignty over Spitzbergen. Denmark believed this on the basis of a conversation between the Danish foreign minister and the Norwegian foreign minister. Denmark believed that Norway had obligated itself by means of the conversation. Norway did not (Harris 1991, 736). 
Clearly some shared convention regarding which acts count as the communication of an intention to undertake an obligation would have been useful to Anita and Bob and Denmark and Norway. But, according to Treaty as Promise, the existence of such a shared social convention is not necessary for Anita and Bob or Denmark and Norway to make promises to one another. Whether Anita has an obligation to Bob or Norway to Denmark, in the cases above, turns upon whether or not they communicated to the other their intention to undertake, by that act of communication, an obligation to act in a certain way and whether or not Bob, in the first case, and Denmark, in the second, believed that this is what they had done. In principle a promise, and hence a treaty, could be made even in a society that lacked any social convention of promising at all. ${ }^{32}$

\section{2d. Moral motivation, not self-interest}

If breaking a promise is to violate a moral obligation then we may expect others to express disapproval of our actions and also, perhaps, to apply sanctions. The disapproval of others and the possibility of sanctions may move us to keep our promises. The promise breaker may also feel a sense of shame at having failed to discharge their obligation irrespective of the attitudes and actions of others. The would-be promise breaker may be anxious to avoid experiencing such shame.

The actions of states, too, can be the subject of disapproval by others. NGOs such as Amnesty International, or governments of other states, might condemn a state like the

\footnotetext{
32 Grotius, for example, makes a clear distinction between the "Stipulation in Form", that is, particular widely accepted rules of promising, and the act of a "deliberate Mind" which is what is central to making a promise. The formal stipulation is, says Grotius, useful as an "undoubted Sign" of the intentional act. But it is not essential (Grotius 2005, bk. 2, Chap. 11, sec. 4.2- 3). Locke and Scanlon, cited by Marshall Cohen as I note above, both think that promises can be made without the use of social conventions.
} 
USA for failing to live up to its human rights commitments. And states, too, can be the subject of sanctions. As a large-scale organization, or association, of people it may make little sense to say that a state can, itself, feel an emotional state like shame. Nevertheless, individual members of the state, including those who represent the state, may feel shame and it is not unknown for states to alter their behaviour based upon notions of 'national honour' (Appiah 2010, 62 - 65).

All of this may be true but, even if it is, it does not capture what is important, according to Treaty as Promise, about having a moral obligation and acting just because one recognizes that one has a moral obligation to do so. That is, Treaty as Promise distinguishes clearly between self-interested motivating reasons to act and moral motivating reasons to act. A promisor who keeps a promise because she recognizes that she has a moral obligation to do so does not keep her promise because she has calculated that she will be better off doing so. Indeed, in some cases she will do her duty even when doing so runs contrary to her self-interested reasons for action (Teson 1998, 79).

So, as we have seen, Anita's self-interest would seem to lead her to break her promise to Bob in May. But if she has made a promise she has a moral obligation to help Bob. This moral obligation overrides other alternative courses of action including those that are in Anita's self-interest. If Anita acts based upon moral considerations then she will help Bob in May simply because doing so is the correct thing to do (ibid). Likewise states (or the governments that represent them) can choose to act in a certain way simply because they believe that doing so is morally right. If they do then they are responding to a moral motivation which cannot be reduced to considerations of self-interest (ibid, $79-80$ ). Indeed, for some authors, such as Janna Thompson, to say that the reason to comply with 
a treaty is primarily prudential, rather than moral, is to say that treaties are not promises at all (Thompson 2002, 6). ${ }^{33}$

\section{What Treaty as Promise gets right}

There is, I think, much that it is appealing about Treaty as Promise. In particular it captures much that is of importance when we talk about treaties as being closely related to promises. I think that there are three intuitively plausible features of treaty making that Treaty as Promise captures well.

\section{$\underline{\text { 3a. Treaty compliance and violation is a moral issue }}$}

Firstly, Treaty as Promise draws attention to the moral significance of treaty making and treaty keeping (and violation). Despite the scepticism of some political realists ${ }^{34}$ we typically do consider treaty keeping to be a matter of moral duty (and treaty violation, all things being equal, to constitute a moral wrong). For example, Hume is criticised by Marshall Cohen for apparently holding that "it would be acceptable for a prince to repudiate his obligations under a treaty" (Cohen 1984, 337). Cohen here appeals to the moral force of treaty commitments and (contra Cohen's reading) Hume agrees, telling us that "no one of ever so corrupt morals will approve of a prince, who voluntarily, and of his own accord...violates any treaty" (T 3.2.11, 568 - 569). It is not uncommon to see

\footnotetext{
${ }^{33}$ As I note in the introduction, the natural law tradition does not always make such a clear distinction between moral and prudential concerns. Grotius, for example, notes that a concern for reputation will lead promisors to keep their promises in addition to recognition of the "moral necessity" of promise keeping (Grotius 2005, bk. 2, chap. 11, sec. 4.3).
}

${ }^{34}$ See chapters 7 and 8 for discussion of political realism. 
appeal made to the 'sanctity' of treaty commitments implying particularly serious and weighty moral reasons not to violate treaty commitments (Waldron 2011, 66). Treaty as Promise explicitly addresses, and captures, these intuitions.

\section{$\underline{\text { 3b. Treaty commitments are self-imposed }}$}

Secondly, Treaty as Promise highlights the self-imposed character of treaty commitments. Anita seems to have no reason to help Bob in May prior to promising to do so. It is the promise that Anita makes that creates such a reason for Anita. States, too, may often find themselves in situations where they have no prior reason to act in a particular manner. By entering into a treaty, however, they appear to self-impose a reason. Treaty as Promise points towards a plausible explanation for this. Because treaties are promises, and promises allow us to generate moral obligations, treaties, too, allow states to generate moral obligations. The idea that reasons for action can be self-imposed in this way by states also comports well with the understanding of treaty making of many international lawyers and diplomats. The idea that sovereign states can bind themselves by making a kind of promise fits well with the actual practice of treaty making (see Robertson 2006, $89-90)$.

\section{3c. Promises are not the whole of morality}

Finally, Treaty as Promise does not commit us to the idea that all of the moral (or other) commitments of states must be self-imposed by states. Some writers worry that thinking about treaty commitments as being closely analogous to promises and contracts in fact corrupts some of the important goals pursued by some treaties, particularly those dealing with human rights. So, for example, Jans Klabbers complains that the "contractual perspective [of treaties]...fails to satisfy the sense of idealism and progress...bound up 
with human rights" (Klabbers 2004, 181 n.42). Treaty as Promise allows us to capture the sense in which states that sign up to human rights treaties thereby seem to self-impose an additional moral reason they lacked prior to signing the treaty whilst denying that this is the only reason that states have to respect human rights. By distinguishing self-imposed reasons from other reasons for action, Treaty as Promise can capture the idea that a human rights treaty is a promise but, as Klabbers' complaint suggests, that this is not the only, or even most important, moral fact about such a treaty.

\section{Commitment Problems}

Let us return to the topic of chapter 1 . How does Treaty as Promise help promisors to change the expectations of promisees? That is, how does a treaty, on this account, signal a credible commitment to others? According to Treaty as Promise, a promisor incurs a moral obligation by successfully communicating her intention to incur that moral obligation. If she succeeds in thereby incurring a moral obligation, and if the promisee believes that she has succeeded in doing so and also believes that the promisor is disposed to act from a sense of duty, then the promisee has reason to change her expectations of the promisor's future behaviour. When these conditions are met a promise will, it seems, be credible.

But there are problems with this account. In the first place it is not yet clear how it is possible to create an obligation, or any other reason, by communicating an intention to do so. If a promisor, whether a person or a state, communicates an intention to give themselves an obligation, it can always be asked by the promisee (or anyone else) whether, and how, the promisor actually has the obligation. A convincing answer to this question, especially from the perspective of the sceptical promisee looking for reasons to 
take the commitment seriously, will need to point to something other than the fact that an intention to be so bound has been communicated (Sheinman 2008, 307 - 308).

Now, I mentioned above that defenders of the normative powers view, including the natural law theorists who explicitly extended it to treaties, suggest that it is the desirability of agents having an ability to create moral obligations that explains the moral force of promises. Promises should be kept, on this view, because there is a moral rule (or natural law) that requires that promises to be kept. This moral rule, itself, is justified by appeal to the important interests that it serves. So, on this view, it would be valuable for promisors to be able to give themselves an obligation to do something by communicating an intention to give themselves that obligation. And this seems right. It would be desirable to be able to create obligations simply by communicating an intention to create obligations. But, unfortunately, the fact that it would be desirable to have an ability to create obligations in this way does not show that agents actually possess this ability (Pratt 2007, 566 - 570). Such an account does not seem to help us explain how promises can act as credible commitments.

From the perspective of the promisee one significant problem is that promises are open to deceptive manipulation. That is, it is generally easy enough for a promisor to make a promise whilst having no intention of actually keeping that promise. Assuming that the promisor can get the promisee to understand that she is making a promise at all, the promisee cannot directly observe the promisor's willingness to comply with the promise. The promisee typically knows that the promisor has some reason not to comply with the promise and is looking for some reason that cancels or counterbalances this reason (Sheinman 2008, 306). The promisor, of course, attempts to furnish such a reason by communicating her intention to undertake a moral obligation. But the promisor may lack 
any intention to actually keep the promise. After all, we know that she has some reason not to keep the promise. This offers promisors the opportunity to deceive promisees by making insincere promises.

Of course, that a promise is insincerely made does not mean that it thereby fails to create a moral obligation for the promisor. Although the promisor does not have the intention of keeping the promise she nonetheless intends to get the would-be promisee to believe that she will do that which she is promising to do (Sheinman 2011c, 11). This is why she makes the promise in the first place. The intention, we might say, is to make a genuine promise in order to later break a perfectly good moral obligation. So, if we can explain how it is possible to create a moral obligation by communicating our intention to create that obligation ${ }^{35}$ we may not need to be unduly worried about instances in which some agents ignore their moral obligations.

From the perspective of the promisee looking for a credible commitment, however, the problem posed by the existence of insincere promisors is a significant one. It is one thing to identify a moral obligation and another to show how the existence of that obligation can be used to create a credible commitment. Some people (including, presumably, statesmen) will be moved to keep their promises from a sense of duty. But not everyone is reliably moved to keep their promises from a sense of duty. Bob seeks reassurance that Anita will actually help him harvest his corn as he knows that she has some reason not to help him. What Bob really wants is for Anita to actually help him harvest his corn not an

\footnotetext{
35 Perhaps, as some philosophers think, we just do possess an inherent normative power to create obligations by communicating our intention to create obligations (Searle 2001, chap. 6). I share Hume's intuition that this is quite mysterious.
} 
obligation on Anita's part to help him harvest his corn (Pink 2009, 392). Of course, it might be pointed out that Bob is interested in Anita's obligation because that obligation is what will motivate Anita to help him. But Anita may be being deceitful when she makes her promise. She may not be moved in this instance by a sense of moral duty. From Bob's perspective, then, it is not clear that Anita has made a credible commitment at all even if we accept that, by making a promise, she somehow creates a new moral obligation.

The point of making a promise, or, according to Treaty as Promise, signing a treaty, is that it is supposed to give the promisor a sufficient reason and motivation to do that which she has promised to do. And the promise is supposed to do this whatever other, countervailing reasons she might possess not to do what she has promised (Scanlon $1998,322)$. Usually a promise is offered or requested in situations where doubt exists as to whether the promisor possesses sufficient motivation to do the thing that is promised. This is the case with Hume's two farmers. It is also the case with France and the USA and the members of OPEC. But other than being told that somehow the communication of an intention to incur an obligation actually incurs an obligation, which may or may not motivate the promisor, it is hard to see how promises are supposed to provide sufficient reason or motive to keep the promise.

Now, the promisor might possess some prior motivating reason to do that which is promised. For example, protecting France by launching a nuclear attack on the USSR might have been in the USA's interests irrespective of the treaty. Or, just as we saw that Anita may have been a member of the farmer's union, membership of NATO might motivate the USA to protect France in this way irrespective of any explicit promise to do so. But these reasons are nothing to do with the promise itself. Should these reasons disappear for some reason, or not be thought to be adequate, the promise itself is 
supposed to provide the reason instead. We are back with the original problem of explaining how promises can be used to make credible commitments. Furthermore, it looks as though we cannot appeal to the existence of a social convention of promising to generate a motivating reason as Treaty as Promise denies that these are essential to making promises or creating moral obligations by means of making a promise.

So, it is unclear how Treaty as Promise can help agents solve their commitment problems. This is partly because it is relatively easy to make insincere promises and that recipients of the promise cannot observe the promisee's willingness to comply with the promise. The more general problem is that it is not clear how a treaty is supposed to provide the promisor with sufficient reason and motivation to do what is promised regardless of whatever reasons she may already have independently of the promise.

\section{Treaty as Humean Promise}

I now want to set out a slightly different position, the position I earlier called Treaty as Humean Promise. I think that it can explain how agents can overcome the kind of problematic commitment problems we have encountered whilst retaining the intuition that treaties are a kind of promise. I shall not provide an overview of who holds, or has held, this view as I did with Treaty as Promise except to say that, as the name suggests, Hume endorses some version of this view (see T 3.2.11; see chapters 5 and 6 for a more detailed discussion of Hume's own application of this view). ${ }^{36}$

\footnotetext{
${ }^{36}$ Although only Hume explicitly applies this view of promising to treaties, others endorse and expand upon the Humean theory of promising more generally. In particular Hanoch Sheinman has developed, and defended, a sophisticated version of the Humean theory of promising in a number of articles (see, in
} 


\section{$\underline{5 a . P r o m i s e s ~ a n d ~ t r e a t i e s ~ c r e a t e ~ s e l f-i n t e r e s t e d ~ m o t i v a t i n g ~ r e a s o n s ~}$}

By making a promise or signing a treaty an agent, say the USA, thereby creates what Sheinman calls a self-interested motivating reason to do that which is promised $(\phi)$ (Sheinman 2008, 297 - 298). What does this mean? The USA has a reason to $\phi$ insofar as there is some fact that counts in favour of the USA $\phi$-ing. One fact that would count in favour of the USA $\phi$-ing would be that $\phi$ is in the interests of the USA. The reason is, then, a self-interested one insofar as $\phi$-ing is in the USA's interest. This means that it is beneficial to the USA or good for USA to $\phi$. The USA is motivated to $\phi$, or, perhaps, those representing the USA are motivated to $\phi$, insofar as the USA is (or its representatives are) moved to $\phi$ to some degree. The USA has a motivating reason to $\phi$ insofar as the USA has both a reason to $\phi$ and the USA is moved to some degree by recognition of that reason (ibid, 297).

So if the USA has signed a treaty promising to protect human rights then, on this account, the USA has a self-interested motivating reason to protect human rights. It has this reason in virtue of having promised to protect human rights. (The USA might well have many other reasons, perhaps motivating reasons, to protect human rights. These reasons are not necessarily self-interested).

\section{$\underline{5 b}$. These self-interested reasons are self-imposed}

The self-interested motivating reason to keep a promise or comply with a treaty is selfimposed. This means something like the following. The intention of the promisor to

particular, Sheinman 2008, 287 - 318 and Sheinman 2011b, 463 - 492). I have also been influenced by Annette Baier's work (see, Baier 1985). 
acquire the motivating reason plays some role in explaining how the promisor ended up with such a motivating reason. Without having the intention to acquire the reason the promisor would lack the reason (although she might have other reasons to do that which is promised) (Pratt 2007, 538 - 539; see, also, section 3b, above).

So, I have a self-interested motivating reason to drive on the left hand side of the road in New Zealand. Insofar as I have this reason, my intention to acquire it is neither here nor there. Assuming that I do not wish to crash my car or be punished for reckless driving (and I am aware of the relevant rule), it is in my self-interest to drive on the left hand side of the road in New Zealand. Even if I decided to drive in New Zealand simply in order to have this self-interested reason my intention to do so need play no role in explaining how it is that I ended up with that self-interested reason which would apply in any case (Pratt 2007, 538). This is not so for self-imposed reasons like the reasons that we incur by making promises and signing treaties. If I promise to help harvest your crops in May, and I would otherwise lack a self-interested motivating reason to do so in May, then I create a self-interested motivating reason to help you harvest your crops in May that I previously lacked. In order to explain why I have this reason we must point to my intention to acquire it.

\section{5c. These self-interested reasons are self-imposed by means of invoking a social convention}

Treaty as Humean Promise is concerned with the question of how it is possible to create a reason to do something simply by communicating an intention to create that reason. This is a feature that remains unclear with respect to Treaty as Promise, according to which we create a specific kind of reason, a moral obligation. Treaty as Humean Promise questions just how such a feat is possible. The short answer, according to Treaty as 
Humean Promise, is that it is not. The slightly longer answer is that it is not possible without also (intentionally) invoking an independent social convention of promising (Sheinman 2008, 308). The rules of the social convention are intended to govern the behaviour of the members of the group that use that social convention. One of the rules of this social convention will be that promises, and treaties, must be kept. To break a promise, or violate a treaty, is to act contrary to the rules of the social convention (just as, say, passing the bottle of port to the right is to act contrary to the rules of a social convention of dinner party behaviour amongst some groups).

To violate a treaty, or break a promise, is not only to act contrary to the rules of a social convention but also to behave in a way that is, in some way, detrimental to oneself in acting contrary to those rules. That is, actions contrary to the rules of a widely accepted social convention will be in some way detrimental to the actor. For example, failing to pass the bottle of port to the left may, in certain circles, see you ostracised from polite dinner parties and subject to the negative judgments of other members of the group. Likewise to make a promise, or sign a treaty, is to intentionally create a self-interested reason to do that which is promised. It is to be subject to some sanction by others if one fails to keep the promise or comply with the treaty.

\section{$\underline{\text { 5d. Self-interested motives, not (necessarily) moral motives }}$}

As we have seen, according to Treaty as Humean Promise, to sign a treaty (or make a promise) is to create a self-interested motivating reason to do that which is promised. This looks like a good thing so far as Anita and Bob are concerned as they are primarily motivated by self-interested concerns, at least with respect to their interactions with one another. 
Such self-interested reasons look appropriate in many commercial transactions. But they may appear to some to be less appropriate with regard to other kinds of promises and treaties. For example, such self-interested motives may strike some as inappropriate in the context of a marriage promise or with respect to treaty commitments that seek to realise important humanitarian goals such as securing human rights or punishing tyrants. After all, promises and treaties can both, sometimes, be made out of concern or kindness for the interests of others (Melden 1977, 93 - 94).

However, it is important to distinguish between the purposes for which a promise or treaty is made and the reasons to keep the promise that are subsequently created. It is perfectly possible for the USA to enter into a human rights treaty merely because its leaders and citizens are committed to the cause of protecting human rights. This commitment amongst the leadership and citizenry of the USA may also continue to motivate compliance with the terms of the treaty irrespective of considerations of selfinterest. And insofar as it is important to uphold global human rights the USA will continue to have a reason to do so even if the leadership or citizenry cease to be motivated to do so.

But the USA may also find itself in circumstances in which it has self-interested motivating reasons to abuse human rights. This is exactly what happened following 9/11 when the USA wanted not to be bound in its treatment of supposed al-Qaeda prisoners by an earlier commitment to Common Article 3 of the Geneva Conventions. Whatever the motives for entering into the Geneva Conventions in the first place, Treaty as Humean Promise argues that the USA (and other signatories) nonetheless created self-interested motivating reasons to comply with those Conventions. That is, actors, even good and conscientious ones, often have self-interested reasons not to do that which is promised 
(Sheinman 2008, 307). By entering into the Geneva Conventions, the USA created selfinterested motivating reasons that act to counterbalance their self-interested reasons to ignore such constraints. There is, of course, nothing in all of this stopping the USA from also upholding the Geneva Conventions because it is the right thing to do.

\section{5e. Protecting reputational capital as self-interested reason}

Hume argues that by promising to do something the promisor "subjects himself to the penalty of never being trusted again in case of failure" (T 3.2.5, 522). By making a promise the promisor grants to the promisee the right to withdraw his trust if the promisor breaks her promise (Baier 1985, 178). Interested third parties, too, may withdraw their trust in the promisor.

If Hume is correct then we do indeed have powerful self-interested reasons to keep our promises. Promise breaking is harmful to the promisor. Why? Because promise breaking, according to Hume, has the result that the promise breaker loses access to the social convention of promising. She will no longer have her promises accepted and no-one will wish to enter into cooperative arrangements with her in the future. Access to the social convention of promising is an extraordinarily useful way of interacting with others, whether it is in order to get one's corn harvested, to forge an alliance, to put an end to conflict, or to commit to, and sustain, worthwhile emotional relationships. Promises are central to many areas of human interaction. Because of this the penalty of never being trusted again is a significant one.

However, the most obvious objection to Hume's claim is that it just does not seem to be true. People break promises, and states violate treaties, without thereby losing all of their 
ability to make future promises. And even if they did lose their ability to make future promises, this is rarely irreversible.

Nevertheless it is possible to lose the trust of others to some extent and for this to do some damage to one's ability to enter into future promises. We can put this in terms of the costs to an agent's reputation. Here we can understand an agent's reputation in a straight forward manner in terms of the judgments that others make about an actor's past behaviour in order to predict their future behaviour (Guzman 2008, 33). Anita, remember, wanted to alter Bob's expectations of her future behaviour in order that Bob would help her to harvest her crops in April. Her ability to do this will depend, at least in part, upon her reputation as a promise keeper and Bob's subsequent judgment of her trustworthiness. If Bob judges Anita to be a reliable promise keeper he will be more likely to alter his behaviour, and help Anita, than if he believes Anita to be unreliable. And what gives reputation its motivating force for Anita is the knowledge that her immediate actions, for example keeping this particular promise to Bob, will affect future judgments by others. The promise breaker loses a valuable ability to enter into future promises. So, in her dealing with Bob, Anita is constrained at least to the extent that others can reliably determine whether or not she has kept her promise. That is, insofar as Bob would know that Anita has cheated him and can communicate this to others, she faces some loss of reputational capital (and, as a result, potential future promises).

We can apply this to states too. Here is a simple model. States that comply with their treaties acquire reputational capital. This is good for states as it allows them to more easily alter the expectations of would-be treaty partners in the future. States that violate treaties, on the other hand, lose reputational capital. This is not good for states as in cases where their reputation is poor, where others anticipate violation of treaty commitments, 
the ability of the state to alter the expectations and behaviour of other states will be relatively weak. ${ }^{37}$ In order to make credible promises, then, such a state will typically need to make more costly concessions to other parties than they would otherwise need, or like, to do. ${ }^{38}$

Take, for example, the Intermediate Nuclear Forces Treaty (INF). This treaty aimed to reduce the nuclear capabilities of the USA and USSR. The problem faced by the USSR was that the USA did not trust them to comply with the treaty and disarm. In order to overcome this problem, and alter the USA's expectations, the USSR needed to make a

\footnotetext{
${ }^{37}$ The model is surely too simple as it stands. It pays no attention, for example, to the costs to a state of keeping a treaty. So, landlocked Luxemburg might sign up to a series of treaties promising to keep its harbours open to all foreign vessels and, on the simple model, might expect to see its reputational capital increased as a result of not violating those treaties. But this is absurd. Clearly the difficulty, and the costs, involved in complying with a treaty will also affect the reputation of a treaty complier or violator. A more sophisticated model, then, would take this into account. An example of a more detailed model, intended to predict state behaviour with respect to international law in general, can be found in Guzman 2008 (73 74). Another interesting account, related to international borrowing specifically, can be found in Tomz
} 2007.

\footnotetext{
${ }^{38}$ There may, however, be some instances in which the rewards of treaty violation seem so great or the risks of discovery so low, that it looks as though the calculation of long-run self-interest would counsel treaty violation. In those situations it may be urged considerations of self-interest should surely lead states to violate their treaties. Such, it seems, would be the reasoning of a figure like Hobbes' Foole (Hobbes 1965 chap. 15). It would be a mistake, I think, to argue that treaty violation never benefits the violator. One thing we can say against the Foole is that, ex ante and at the moment of decision, the wouldbe violator is not in a position to determine whether this particular opportunity for violation is one that would be beneficial or not. I develop this argument, which is inspired by an argument by Gregory Kavka, in more detail in Chapter 8 of this thesis.
} 
series of concessions more significant than any they had accepted previously, including invasive monitoring of treaty compliance (Kydd 2000, 344; see, also, Guzman 2008, 38).

When entering into a treaty states want their promises to be credible. The reputation of that state determines the extent of that credibility. Furthermore, as the anticipated costs of doing what is promised increase states need greater credibility. As the amount of credibility required increases the state in question requires a stronger reputation for treaty compliance if their promises are to be believed (Guzman 2008, $74-76$ ). In short, it is of value to a state to have a good reputation. The better the state's reputation the more credible are its treaty commitments. And the more credible its treaty commitments the more it can expect to gain in the future.

\section{Commitment problems}

I think that Treaty as Humean Promise offers a good account of how actors can make credible commitments to one another by making promises to one another. We have already seen how. By entering into a treaty a state alters the costs to that state of undertaking action contrary to that treaty. Once the commitment is made it is sustained by factors that are external to the actor (Fessler and Quintellier 2013, 469). In this way entering into a treaty is like Anita's commitment by means of the Farmer's Union. In that instance the costs of a failure to help Bob did not depend upon the extent of Anita's psychological commitment to helping Bob, the sincerity of Anita's intention to help Bob, or Anita's recognition of a moral duty to help Bob. Because Bob does not need to directly observe Anita's willingness to comply with her commitment in order to predict her future behaviour, but can directly discern the costs to Anita of failing to help him, Bob can more confidently predict Anita's future behaviour. In the same way by entering into a treaty 
states alter the costs of taking alternative action. Failing to comply with a treaty negatively impacts upon the reputation of that state. Other states can more accurately predict how that state is going to behave in the future based upon their judgment of that state's reputation for treaty compliance. If a state has a very poor reputation then others might refuse to enter into treaties with it at all. The state in question might become a kind of global pariah. Or, if this is not feasible, then other states might demand significant concessions of the state as a condition of making the treaty at all just as we saw the USSR had to do with respect to the INF Treaty. Furthermore these other states have an incentive to bear any costs associated with punishing a treaty violator in this way. In so doing they avoid undertaking potentially expensive commitments to unreliable treaty partners.

By making a promise an actor can create costs that they will bear should they break the promise. Although they still have self-interested reasons to break the promise they nonetheless create other self-interested reasons to do that which is promised. It is possible, of course, that some states will place little value on maintaining a reputation for treaty compliance. For example, North Korea could almost certainly improve its reputation by entering into, and being seen to comply with, treaties limiting the development of its nuclear programmes. But North Korea has very little reputational capital to begin with and building it, at least from such a baseline, can be a costly, and slow, process (Guzman 2008, 81). Given these facts North Korea may believe, and may be correct to believe, that they would do better to cultivate a reputation for motivational instability instead. (The USA, for example, may be unwilling to attack North Korea if there is a reasonable chance that North Korea will launch a deadly assault upon Seoul). But the low costs to North Korea of an act of treaty violation can typically be easily understood 
and observed by would-be treaty partners. Promises from North Korea are, then, relatively unreliable.

Earlier I noted that promises are subject to deceptive manipulation. This is as true for Treaty as Humean Promise as it is for Treaty as Promise. For Treaty as Promise the problem was that promisees could not directly access the intentions of promisors. This is, of course, equally true if we accept Treaty as Humean Promise. However, the costs to the state of any act of treaty violation are typically observable. It is in this way that treaties from North Korea, in the example used above, will be considered relatively unreliable.

That states, and their representatives, can use promises to mislead is clear enough. Take, for example, the Munich Agreement (1938). This agreement between Germany, Italy, France, and the UK allowed Germany to annex the Sudetenland in return for German promises not to annex other parts of Europe. But Germany later went on the annex the rest of Czechoslovakia and to attack Poland. German ambitions were such that they attached little value to cultivating a good reputation for treaty compliance. Although Germany's reputational capital did suffer as a result of violating the Agreement it nonetheless calculated that it could gain more through violation, and misleading Britain and France, than it could by complying with the treaty.

Now, perhaps German failure to comply with the Munich Agreement was reasonably foreseeable. There were certainly those in Britain who seemed to see through the deception. ${ }^{39}$ Nevertheless, whether through miscalculation, incorrect prior beliefs about

\footnotetext{
${ }^{39}$ Winston Churchill, in a speech in the House of Commons, denounced the agreement as placing no real boundaries on German expansionism at all. (Speech available at
} 
the Nazi government, or wishful thinking on the part of Britain and France, the Munich Agreement illustrates that we should not expect treaty making to be immune to deceptive manipulation even when we understand treaties as Humean promises. Treaty as Humean Promise must make a more modest point and that is that on the account offered here treaties, and promises more generally, can be more easily subjected to systematic inspection by interested third parties than can the moral obligations identified by Treaty as Promise and it is this fact that increases the reliability of treaty commitments (see Fessler and Quintelier 2013, 469 - 470).

It is important to be aware that there are limits to the effectiveness of reputational sanctions in shaping the behaviour of states. There are means that can be (and have been) employed to increase state compliance with treaties. Once we have identified the selfinterested motivating reason generated by most treaties we can put institutions and instruments in place to strengthen the motivating power of these reasons. For example, once treaties come into force they are registered and made public by publication through the United Nations (Aust 2007, 347 - 348). The more widely a treaty commitment is publicised the greater the chances are that other parties will become aware of its violation. Alternatively states can build monitoring and reporting requirements into their treaties. The point of these kinds of requirements is to try and increase the force of reputational sanctions on the grounds that better information will, generally, promote treaty compliance.

http://www.winstonchurchill.org/learn/speeches/speeches-of-winston-churchill/101-the-munichagreement, accessed 20/05/2014.) Churchill was, in 1938, if not a solitary voice of caution, in a minority. 
I think, then, that Treaty as Humean Promise offers a plausible explanation of how promises generally, and treaties in particular, can create credible commitments. It does so by offering an explanation of how it is possible to generate a reason to keep a promise by communicating an intention to create that reason. It explains this by arguing that, in making a promise, an agent invokes a social convention of promising such that failure to keep the promise is contrary to the rules of the social convention. Failure to keep the promise is contrary to the rules of the social convention of promising and acting contrary to these rules is not in the interests of the promisor insofar as it affects her reputation. It is in this way, then, that Hume's two farmers can hope to overcome their commitment problem by promising to help one another. And it is in this way that states, too, can hope to overcome their commitment problems by entering into treaties with one another.

\section{What about moral reasons?}

Treaty as Humean Promise, then, offers an account of how treaties can create credible commitments. I think that it does so better than Treaty as Promise which, I suggested, struggles to account for the motivating reason that promisors have to do what is promised and hence for the promise recipient's expectation that the promisor will keep the promise. However it might be thought that Treaty as Humean Promise fails to capture what is important about calling a treaty a promise at all.

When I presented Treaty as Promise I noted three advantages that I thought that the account possessed. These are that it captures the sense that treaties create reasons to do what is promised where no such reason existed previously, that there may be numerous reasons to comply with a treaty other than the fact that it is a promise, and, finally, that treaties create moral reasons to what is promised. I think that Treaty as Humean Promise 
captures the first and second of these. But there seems to be little room in Treaty as Humean Promise for the notion that treaties create moral reasons to act or that Germany, say, acted morally wrongly in violating the Munich Agreement.

I think that Treaty as Humean Promise can offer a plausible account of the moral reasons that states have to keep their treaties. However, I turn to look in more detail at the different reasons, including moral reasons, which states have to keep their treaties, according to the Humean account, in the next chapter. 


\section{Chapter 3: Treaties and morality}

In previous chapters I presented Hume's example of the two farmers and extended this example to structurally similar situations faced by states in international affairs. I set out the Humean account of the reasons that promisors have to keep their promises to one another despite the fact that it does not seem to be in their self-interest to do so. The Humean account argues that it is in fact in their self-interest, a fact that we can understand once we realize how promising involves the intentional invocation of an independent social practice of promising.

In this chapter I take up the worry that 'Treaty as Humean Promise' seems to be troublingly silent about the moral obligation to comply with a treaty. I do so by discussing and assessing three common accounts of the moral obligation to keep a treaty. I conclude that there is not one source of the moral obligation to comply with a treaty per se. There are different moral and non-moral considerations that tell in favour of or against treaty compliance or violation in different circumstances.

\section{Introduction}

The ability to make a credible commitment is often required when there is doubt regarding the future behaviour of a state. Entering a treaty to reduce $\mathrm{CO} 2$ levels, for example, is supposed to give states a reason to reduce $\mathrm{CO} 2$ levels which they previously lacked. Insofar as the treaty achieves this purpose, it also provides other states with some reason to expect that their treaty partners will reduce $\mathrm{CO} 2$ levels. The challenge is to give some account of what reason entering a treaty gives states. The answer to this challenge offered by Treaty as Humean Promise is to say that by invoking a social conventional rule 
of treaty making, a state creates a self-interested reason, grounded in reputational concerns, to comply with the treaty.

Despite offering an account of the value of the practice treaty making, Treaty as Humean Promise is not, as things stand, committed to the claim that treaty compliance is a matter of moral obligation. In principle a society of entirely amoral agents can make and often be expected to keep their treaty promises to one another. In this sense it differs from the view I called Treaty as Promise. For Treaty as Promise, the reason that a state has to comply with a treaty is first and foremost a matter of moral obligation.

\section{Morality}

Many philosophers deny that we have merely self-interested reasons to keep our promises. This is due to two related features they discern in promises. Firstly, promises seem to have peremptory normative force. There is an obligation to keep a promise, not merely a (self-interested) reason to do so. Secondly, this obligation is a moral obligation. Let me say a little about each of these features in turn. When applied to treaties, the first feature is not really a problem for Treaty as Humean Promise. The second feature may be. It will be the focus of the remainder of this chapter.

In the first place, promise keeping appears to be obligatory. That is, the reason that we have to keep our promises is normally thought to possess peremptory normative force. If I make you a promise I no longer seem to be free to decide whether or not doing keeping the promise is really in my best interest. I am required to act as I have promised, at least all else being equal. The peremptory force possessed by promises is recognized even by those who hold that we have prudential reasons to keep our promises. Thus Thomas Hobbes says that "when a man hath (by covenanting, i.e., promising) abandoned or 
granted away his right, then he is said to be OBLIGED or BOUND...and that he ought, and it is DUTY" (Hobbes 1965, chap. 14).

Treaty as Humean Promise does not deny that there are obligations to comply with a treaty or keep a promise. By making a promise, or entering a treaty, the promisor makes the promised action obligatory. She is no longer free to decide whether or not to do it. She cannot simply change her mind (as she is usually thought to be able to do if she merely states an intention to do that thing). What gives the promise or treaty its force is the recognition of the obligation by other members of the relevant community. Moreover, the promisor transfers to the promisee, by means of the social convention, the right to diminish, and perhaps destroy, her reputation and future promising power in case of nonperformance (Baier 1985, 198 -199). Typically, the promisee also has the right to waive the requirement that the promisor keep her word.

Secondly, however, the obligation to keep a promise is typically considered to be a particular kind of obligation. It is not (merely) a social obligation but, rather, a moral obligation. Someone who breaks a promise does something morally wrong. By breaking a promise they may also be morally blameworthy. They are not thought to be merely imprudent or unwise, or guilty of a social wrong-doing, as the Humean account suggests. For example, H.L.A Hart claims that "[p]romises constitute the obvious case of moral obligation. When we promise we make use of specified procedures in order to change the moral situation...we exercise a "power" conferred by rules to change moral relations" (quoted in Sheinman 2008, 294).

So, promises are widely taken to impose moral obligations on promisors. Treaty as Promise claims, as we saw, that treaties impose moral obligations on states. The claim 
that treaties impose moral obligations has struck many as highly plausible, perhaps even obvious.

I have noted in previous chapters that a number of philosophers think that treaty keeping is morally obligatory. For some philosophers, states, like individual persons, possess a normative power to create obligations by successfully communicating their intention to create that obligation. This was the view, for example, of Hugo Grotius ${ }^{40}$ (Grotius 2005, bk. 2, chap. 14, sec. 4), Samuel Pufendorf (Pufendorf 2005, bk. 2, chap. 3, sec. 23; bk. 3, chaps. 3 and 4, secs. 1 and 2), and Emer de Vattel (2008, bk. 2, chap. 12, sec. 163). All three understood the moral obligations of states as closely analogous to the moral obligations of individual persons to keep their promises. ${ }^{41}$

Some contemporary philosophers also consider treaty compliance to be morally obligatory. For John Rawls, for example, that rule that "[p]eoples are to observe treaties and undertakings" is not just a good rule of thumb but a principle of justice, at least “among free and democratic peoples" (Rawls 1999, 37). And, as I have previously noted, both Fernando Teson and Janna Thompson have recently argued that there is a moral obligation to observe treaties and that this moral obligation is ultimately derived from

\footnotetext{
${ }^{40}$ Strictly speaking Grotius is talking about treaties made by a "King" but in his public, rather than private, capacity. The King makes promises on behalf of the political community as a whole as is made clear by the rest of Grotius' discussion.

${ }^{41}$ As Richard Tuck has argued, these authors would have understood the obligations of individual persons by reference to the obligations they understood to be possessed by sovereign states. That is, they developed their account of promises amongst individual persons from their account of treaty making
} (Tuck 1999, $84-85$ ). 
the fact that treaties are kinds of promises (Teson 1998, 90. 101 n. 66; Thompson 2002, 6).

It is not only philosophers who think that treaty compliance is morally obligatory. It is common for politicians, courts, jurists, and others to refer to the moral obligation to comply with treaties. For example, Woodrow Wilson claimed that even if some of the terms of the Treaty of Versailles (1919) were not legally binding they were, nonetheless, morally binding (Woodrow Wilson, cited in Klabbers 1998, 145). Arnold McNair, in The Law of Treaties, assumes that there is a moral obligation to comply with treaties in addition to the legal obligation to do so (McNair 1961, 6). Hans Wehberg goes as far as to claim that the moral wrong involved in violating a treaty "is so immense that...material amends cannot possibly give the wronged party a true reparation" (Wehberg 1959, 783).

There seems to be a widely held intuition, then, that both promise making and treaty making involve incurring a moral obligation to act. To violate a treaty, on this view, is to commit a moral wrong. In this chapter I discuss what this moral wrong could be.

\section{Three accounts of the moral obligation to comply with a treaty}

In the remainder of this chapter I will state and assess three common accounts of the moral obligation to comply with a treaty. They are as follows:

Firstly, I will discuss a widely held view that the moral wrong of violating a treaty is the moral wrong of acting contrary to the valuable social convention of treaty making. I will call this view the 'practice-consequentialist' view (see, also, Sheinman 2008, 316). There are, roughly, two forms that it can take.

According to the most popular form of the argument, the moral wrong of treaty violation consists in undermining the valuable social convention of treaty making. The other form 
that the practice-consequentialist argument can take is to say that a treaty violator freerides on the useful social convention.

I shall argue that the first form of the argument is only plausible for some treaty violations in certain circumstances. It does not offer an account of a moral obligation to comply with every treaty. The free-rider argument, I shall argue, is ultimately question- begging. It relies upon a prior claim about the moral responsibility to comply with a treaty, which is what we want to establish.

Secondly, I will discuss the view that the moral wrong of treaty violation consists in undermining the legitimate and deliberately cultivated expectations of others. These others may be other governments, groups of citizens (including the citizens of the treaty making state), or individual persons who come to rely in some way upon the treaty being kept.

I shall argue that it is plausible to claim that treaties raise the expectations of others, whether foreign governments, companies, individual persons, or other agents. Indeed, this is part of the purpose of many treaties. Treaty as Humean Promise offers a plausible explanation of how making a treaty can achieve this purpose. It may, furthermore, be morally wrong to disappoint those deliberately cultivated expectations. However, not every treaty generates or is intended to generate such expectations.

Finally, I will discuss the view that the moral wrong of violating a treaty follows from the moral importance of treating states as autonomous entities. This view is suggested by a disagreement between Hugo Grotius and Robert Goodin who employ it in order to draw very different conclusions. The plausibility of the view relies upon the success of an analogy with the value of autonomy for individual persons. 
The analogy between states and individual persons is, however, imperfect. Ultimately, the value of political autonomy is merely instrumental. Insofar as members of treaty-making groups want to be taken seriously they will have reason to comply with treaties, even those made by members of previous generations. This is the same kind of argument offered by Treaty as Humean Promise. The focus on the political autonomy enjoyed by some states, then, ultimately complements Treaty as Humean Promise.

Before I begin, however, let me note that sometimes states enter treaties to do what they already seem to have a moral obligation to do. So, states can enter into treaties promising not to commit genocide or abuse human rights. In these instances the moral obligation can be derived straightforwardly from the content of the treaty. However, what I am interested in in this chapter is what additional moral obligation, if any, arises from the fact that the state in question has entered a treaty.

\section{Practice-consequentialism}

Hume's discussion of promise-breaking leads him to note that, due to broken promises, "the violations of equity must become very frequent in society, and the commerce of men, by that means, be render'd very dangerous and uncertain" ( $\mathrm{T}$ 3.2.7, 535). That is, individual broken promises serve to undermine the general trust, and by extension the social convention of promising, which makes particular promises possible. Your broken promise helps to show to me "that I should be the cully of my integrity, if I alone shou'd impose upon myself a severe restraint among the licentiousness of others" (ibid). Each keeps her promises, according to Hume, partly because she expects her fellows to do likewise (see T 3.2.5, 522). 
According to Hume, then, each person will keep her promises if she is assured that others will do likewise but will break her promises if she is not so assured. Furthermore, her promise breaking (and that of each of her fellows) will predictably lead to a situation in which all break their promises. A situation in which no-one keeps her promises is, moreover, very dangerous and uncertain.

Assuming that no-one wants to face such a very dangerous and uncertain situation, we have two additional reasons, on Hume's account, to keep a promise. The first is a selfinterested reason which is additional to the penalty of never being trusted again. If we are self-interested we will want to avoid the very dangerous and uncertain situation in which promises cannot be relied upon (unless we are sure that we are strong or clever enough to benefit from it). The second is a moral reason. Given that everyone wants to avoid the very dangerous and uncertain situation, it is morally wrong to act in a way that undermines the general trust, and the social convention that makes promises possible. Promise breaking undermines the general trust and social convention and in doing so the promise breaker harms everyone who relies upon the social convention by making their lives dangerous and uncertain. In this way, Hume tells us, self-interest and moral considerations concur in requiring that promises be kept (ibid, 523).

Hume, then, arrives at a moral reason to keep a promise. Let us call the argument which leads to this reason the 'danger and uncertainty argument.' Whatever its prospects for accounting for the moral reasons individual persons have to keep their promises ${ }^{42}$ our concern is with treaty obligations. Is the 'danger and uncertainty argument' plausible with respect to treaty obligations?

\footnotetext{
${ }^{42}$ David Gauthier has called the argument "preposterous" (Gauthier 1992, 418).
} 


\section{Danger, uncertainty, and treaties}

The 'danger and uncertainty argument', applied to treaty relations, has appeared plausible to many people in one form or another. Take, for example, the following statement by the Atlantic Council responding to the Soviet withdrawal from the terms of the Inter-Allied Agreement on Berlin in 1958:

"no state has the right...to free itself unilaterally from its contractual obligations... such a procedure destroys the mutual trust between nations which represents one of the foundations of peace" (Atlantic Council, quoted in Wehberg 1959, 784).

A similar account is offered by Hume's contemporary, Emer de Vattel:

"As all nations are interested in maintaining the faith of treaties, and causing it to be every-where considered as sacred and inviolable, so likewise they are justifiable in forming a confederacy for the purpose of repressing him who testifies a disregard for it, - who openly sports with it,- who violates and tramples it underfoot. Such a man is a public enemy who saps the foundations of the peace and common safety of nations" (Vattel 2008, bk. 2, chap. 15, sec. 222).

The same point can be found in the text of treaties. For example, the preamble to the Covenant of the League of Nations explicitly notes that, in order to secure international peace and mutual security, states must show "scrupulous respect for all treaty obligations." 43 When Hitler reintroduced universal military training in Germany, contrary to the terms of the Treaty of Versailles, the Council of the League of Nations cited the role

\footnotetext{
${ }^{43}$ See 'The Covenant of the League of Nations,' http://avalon.law.yale.edu/20th century/leagcov.asp, accessed 17/09/2014.
} 
of treaty compliance in promoting mutual security between states as a reason for Hitler not to violate the treaty (Wehberg 1959, 784 n.44). On the account offered here it was morally wrong of Hitler to undermine international peace and security by violating Germany's treaty commitments.

\section{Assessing the 'danger and uncertainty argument'}

The 'danger and uncertainty argument' argument looks quite plausible when we are talking about German re-armament prior to World War II (at least with the benefit of hindsight). It also seems plausible when we are talking about Soviet withdrawal from a form of international cooperation during the Cold War and just two years after Khrushchev had publicly predicted that the USSR would "bury" its enemies. But the argument lacks plausibility in many other cases.

Take, for example, Article 246 of the Treaty of Versailles. ${ }^{44}$ Article 246 required Germany to hand over the skull of the Sultan of Mkwawa to the British. Germany did not hand over the skull. However, The Council of the League of Nations did not see fit to remind Germany that international peace and security depended upon Article 246 being kept. Handing over the skull of the Sultan of Mkwawa was just not very important, not even to the British. The Article was ignored without any apparent unpleasant consequences. The social convention of treaty making was not obviously undermined and peace was not, apparently, jeopardised.

So, the 'danger and uncertainty argument' seems plausible enough in some instances. But these are likely to be instances of treaty violation within a hostile and volatile international situation or of the violation itself threatening war or in cases where what

\footnotetext{
${ }^{44}$ See 'The Versailles Treaty,' http://avalon.law.yale.edu/imt/partviii.asp, accessed 23/09/2014.
} 
the treaty requires is considered important by the other party or parties. It is, on the face of it, implausible when these kinds of circumstance do not exist or where the Article of the treaty breached appears unimportant to the treaty partners.

\section{Transgressions and violations}

Defenders of the 'danger and uncertainty argument' may wish to draw a distinction between transgressing particular provisions (or Articles) of a treaty and violating a treaty as a whole. Danger and uncertainty, they might say, arises when a treaty as a whole is undermined. For example, Article 246 was a particular provision of the Treaty of Versailles but its transgression by Germany did not threaten to subvert the purpose of the treaty as a whole. Article 246 was, we might say, incidental rather than central to the treaty. The re-introduction of universal military training in Germany, contrary to other provisions of the treaty, did threaten to subvert the treaty as a whole. Part of the purpose of the Treaty of Versailles was to ensure peace in Europe and for that reason seems to be much more serious.

Some transgressions of particular provisions of a treaty undermine the integrity of the treaty as a whole whilst others do not. The former kind of transgression, we might say, is more serious than the latter. A serious transgression often goes by the name of a 'material breach' of a treaty. Let us call the failure to comply with a particular provision of a treaty a transgression. A transgression that results in a material breach of the treaty, thus threatening to undermine the integrity of the treaty as a whole, we can call a violation of the treaty. Treaty violations are, generally, more serious than mere transgressions. Violations threaten to undermine the very purpose of a treaty. In doing so, treaty violations might appear to threaten the relations between states grounded in that treaty in a way in which mere transgressions do not. By failing to return the Sultan of Mkwawa's 
skull, Germany did not undermine the other provisions of the Treaty of Versailles or the relationships built upon them. The same is not true of German rearmament, which violated the treaty.

\section{Some violations are more important than others}

The distinction between transgressions and violations is an important one. However, even accepting the distinction, some treaties, taken as a whole, are more important than others. A violation of the Inter-Allied Agreement on Berlin plausibly threatens the foundations of peace between states. It is difficult to believe that a violation of the Stresa International Convention for the Use of Appellations of Origins and Designations of Cheeses (1951) would have the same outcome. Or consider a violation by Italy of the Agreement on Cooperation in the Field of Tourism (1991) with Brazil. Whilst no doubt important to the parties involved, Italy's violation does not credibly threaten the foundations of peace between states. Indeed, if Treaty as Humean Promise is correct then Brazil, and third party states, can isolate and impose a penalty on Italy without the need for force or the threat of force. ${ }^{45}$ The parties to the Inter-Allied Agreement on Berlin, on

\footnotetext{
${ }^{45}$ One of the examiners of this thesis, Edwin Mares, rightly points out that Brazil can retaliate even if Treaty as Humean Promise is false. When I say that Brazil can retaliate I am making a claim about some kind of entitlement but, asks Mares, what kind of entitlement do I have in mind? Surely not a moral entitlement if treaties are, in principle at least, independent of moral norms.
}

So, what kind of entitlement do I have in mind? Well, according to Treaty as Humean Promise, there are certain conventionally defined rules that a treaty maker must fulfil if she is to comply with a treaty. By entering a treaty she grants, by means of the relevant convention, the other parties to that treaty the power to do damage to her reputation by making it known that she has violated the treaty. Now, what counts as appropriate exercise of the power of reputation damaging on the part of the other parties to the 
the other hand, have demonstrated some willingness to resort to force to support their claims. As some of the parties are nuclear states, a threat of force should be taken very seriously. It is this fact, rather than treaty violation per se, that renders Soviet violation of the treaty a threat to international security and a plausible moral wrong.

\section{What if every state violated its treaties?}

Proponents of the 'danger and uncertainty argument' might point out that it is a mistake to view individual acts of treaty violation (and even transgression) in isolation from the total pattern of treaty violations. This is the line of argument that Hume adopts in the Treatise. It is only the "steady prosecution of the rule" which leads to "peace and order...in society" (T 3.2.2, 497). Hume is talking about a society of people here but he also thinks his argument applies to the society of states (T 3.2.11, 567 - 569). So, for example, Italy's violation of the Agreement on Cooperation in the Field of Tourism may not seem very important in itself but it is important insofar as it contributes to increasing levels of distrust between states. Each act of treaty violation chips away, as it were, at the mutual trust between states and it is this, ultimately, that results in international security being undermined.

This argument, if correct, is important for the following reason. Sometimes an individual act of treaty compliance may not seem to be desirable or valuable. It may, in other words, seem to serve no purpose or even be pernicious. What does it really matter if France gives

\footnotetext{
treaty will, itself, be determined by the rules of the convention. To say that Brazil can retaliate is, then, to say that Brazil is justified in retaliating in a particular way according to a set of widely understood conventional rules. This suggests that there are important (conventional) duties for promisees as well as for promisors.
} 
some cheese a different name, contrary to the Stresa Convention, Germany does not hand over a skull, or Italy does not share promotional tourism materials with Brazil? But, on the view canvassed here, it would be a mistake to think that treaty compliance even in these instances serves no purpose. Treaty compliance, as a part of a broader pattern of treaty compliance, helps to secure international peace and order.

The relevant undesirable consequences are, then, those that result when every state violates its treaties, rather than the particular consequences of each and every state violating its treaties on particular occasions. So, Italy's violation of its treaty commitments may or may not have undesirable consequences taken in isolation. But if every state acted as Italy did, this would have undesirable consequences. However, this raises the following question. How can we get from a claim about the consequences of every state (collectively) violating its treaties to a claim about what all states (individually) ought to do(see Holmes 1963, 319)?

Let us accept that if all states collectively violated their treaty commitments the consequences would be worse than if all states complied with their treaty commitments. In other words, let us accept that it would not be right for all states collectively - that is, at roughly the same time - to violate their treaties. It is plausible to claim that where the consequences of every state's actions are undesirable, not every state ought to perform those actions (at least if not doing so would mitigate the harmful consequences) (ibid). But this just means that some states (but not necessarily all) ought not to violate their treaty commitments at roughly the same time. It is not necessarily wrong for any one state to violate its treaty obligations just so long as one condition is met. This condition is that it is wrong of that state to violate its treaty commitments whenever this coincides 
with treaty violation by every other state (or, at least, enough states to result in the undesirable consequences occurring) (ibid, 321 - 322).

On the view sketched above, the justification of any particular state's treaty violation turns upon what every other state can be expected to do. If Italy reasonably expects other states not to violate their treaty commitments and (importantly) if Italy's violation does not encourage them to violate their treaty commitments, the supposed consequences of all states collectively violating their treaties does not tell us whether or not Italy is wrong to violate this particular treaty.

However, against this conclusion, it might be claimed that Italy does undermine the mutual trust between states so that other states become more likely to violate their treaties, further undermining the mutual trust between states and thus leading more states to violate their treaties in turn. This is Vattel's point when he claims that the treaty violator "saps the foundations of peace" (Vattel 2008, bk. 2, chap. 15, sec. 222).

\section{Can Italy undermine the foundations of peace?}

Perhaps, then, Italy's treaty violation will, indeed, encourage other states to follow suit. If Italy violates its treaty commitments then other states will violate their treaty commitments. The supposed undesirable consequences arise when all (or, at least, enough) states violate their treaties. By leading other states to violate their treaties Italy will have acted wrongly. Italy's violation not only coincides with treaty violation by every other state but, on this account, is responsible for those violations.

This argument is not very convincing for a couple of reasons. Firstly, if Italy violates the Agreement on Cooperation in the Field of Tourism, it gives Brazil, and other states, a reason to distrust Italy in the future. But this distrust can be effectively directed against 
Italy in particular. It need not involve general distrust of any other state or the generalized distrust upon which the 'danger and uncertainty argument' depends. Indeed, distrust of Italy with respect to its tourism commitments need not even generate distrust of Italy with respect to the content of any other treaty. Italy may continue to be seen as trustworthy with respect to military or environmental treaties but untrustworthy with respect to tourism treaties. Distrust, like trust, does not seem to be diffuse in the way required by the 'danger and uncertainty argument.'

Secondly, a certain level of distrust between states will predictably see states increase the resources they spend in monitoring treaty compliance making widespread treaty violation less, rather than more, probable. ${ }^{46}$ If states distrust one another, and thus cannot be sure that their treaty partners will comply with their commitments, it is reasonable for them to spend time and resources monitoring the compliance of other states. Of course, such monitoring is costly. It involves time and resources that could be used on other things. Where there are high levels of trust between states, because states routinely comply with their treaties, such monitoring will, most likely, be less prevalent than in situations where there is a high degree of distrust between states. The less monitoring there is, the more tempting opportunistic treaty violation will become as the likelihood of discovery, and subsequent penalisation, diminishes.

Because some states will be tempted to opportunistically violate their treaty commitments, other, distrustful, states will spend time and resources monitoring their treaty partners. As a result many other states, even those already inclined to comply, will

\footnotetext{
${ }^{46} \mathrm{~A}$ similar argument related to interpersonal, rather than interstate, interactions has been made by David Friedman (see 'A Positive Explanation of Virtue', available at http://www.daviddfriedman.com/Libertarian/Virtue1.html , accessed 15/09/2014).
} 
have an additional reason to comply with their treaties, thus avoiding the penalties involved in treaty violation being discovered. If distrust and treaty violation between states increase, we should expect to see more resources devoted to effective monitoring. The more resources are devoted to monitoring, the greater the risk of treaty violations being discovered and appropriate penalties applied. As the amount of monitoring increases treaty violation will become less profitable. In this way it seems unlikely that distrust as a result of treaty violations will become so rampant as to undermine the peace and security of states (unless states have some treaty independent reason to distrust one another, as in the Cold War scenario). Of course, as I note, such monitoring is costly and increasing levels of distrust will increase those costs. ${ }^{47}$ There may be a wrong involved in contributing to such costs but it is not the wrong of undermining the social convention of treaty making or the foundations of peace between states.

So, the kind of consequentialist considerations offered above are not very plausible except, perhaps, in certain circumstances such as German rearmament and Soviet withdrawal from forms of international cooperation. Neither the social convention of treaty making nor the peace and security of states is credibly threatened by individual acts of treaty transgression or violation.

\footnotetext{
${ }^{47}$ As Simon Keller has pointed out to me (personal comm.), at some point the costs of increased monitoring may become prohibitive in which case we are unlikely to see further treaty violations being met with increased surveillance.
} 


\section{Free-riding}

An alternative account of the wrongness of violating the rules of the social convention of treaty making can be adapted from Rawls' account of the wrongness of breaking a promise. Rather than focusing on the bad consequences of treaty violation, this argument focuses on the benefits that parties to the convention obtain from it and the wrong involved in attempting to free-ride on that convention. The idea is that it is unfair to exploit a (just) social convention by making use of its rules without also following those rules. Those who do accept the restrictions on their behaviour imposed by the rules of the convention have a right that others accept those restrictions too (Rawls 1971, 342 $343,112)$. The moral obligation to keep a promise, or comply with a treaty, is thus derived from a more general moral principle of fair dealing (ibid, 344). So, on this account, the problem with Italy's violation of its treaty with Brazil is that Italy attempts to secure the advantages of treaty making without obeying the rules of the convention. Italy receives benefits it does nothing to support. Italy thereby acts unfairly. ${ }^{48}$

\section{Assessing the free-rider argument}

The wrong of free-riding is grounded in a general moral principle: on the Rawlsian account a principle of fairness. Here we need to be careful. The wrong involved in receiving a benefit one does nothing to support is the wrong of avoiding a duty to

\footnotetext{
${ }^{48}$ This line of argument, specifically applied to the relations between states, has been advanced by Thomas Franck. For Franck, states comply with agreements and follow rules that they see as having come into being and as operating in accordance with widely accepted principles of fair and right process (Franck 1990, 24). It is sufficient for Franck's argument that the rules be merely perceived to be fair even if, in fact, they are not.
} 
contribute to the provision of that benefit. But it is not sufficient to point to the receipt of a benefit and an absence of a contribution to identify a wrongful shirking of a duty. As we shall see in a moment, the normative work in the free-rider argument is being done by the claim that a state has a moral responsibility to comply with its treaty commitments. But it is precisely the existence, and extent, of this moral responsibility that we want the free-rider argument to establish.

One way of understanding the unfairness of free-riding is as I have presented it above. It is wrong, and unfair, to profit from some mutually advantageous cooperative scheme by benefiting from the efforts of others without contributing to those efforts. But is it really always morally wrong, or unfair, to benefit from a collaborative scheme without also contributing to it? Not necessarily.

Imagine, for example, someone born with a severe disability. She is unable to support herself, work, or contribute to mutually advantageous collaborative endeavours. She receives but does not contribute towards public healthcare paid for through public taxation. Has she acted unfairly? Perhaps. The answer to this question, however, does not depend on whether she is benefiting from the work of others without contributing but, rather, on whether we think she is eligible for the healthcare independently of her ability to pay anything towards it. ${ }^{49}$ Different answers are, of course, possible. But we can reasonably disagree on the answer even if we are both well aware that she benefits from a scheme to which she does not contribute. If we want to know if she has acted unfairly

\footnotetext{
49 This point was partly inspired by the following blog post: http://branemrys.blogspot.co.nz/2012/03/free-rider-problem.html, accessed 28/08/2014.
} 
in benefitting from a collaborative scheme without contributing to it, we must first establish whether she has a duty to contribute to that collaborative scheme.

It is perfectly possible for individuals to have entitlements under a collaborative scheme even if they do not contribute to it. The severely disabled person in the example above may be such a person. The wrong of free-riding, then, is just the wrong of shirking a responsibility to contribute to some social scheme or other. We must allocate responsibility before invoking the free-rider argument if we want to determine whether an agent acts wrongly in claiming some benefit. 50

What does this mean for Italy's treaty violation? The plausibility of the claim that Italy has acted unfairly in violating its treaty, because it has free-ridden on the convention of treaty making, depends on first determining that Italy has a duty to contribute to the maintenance of the social convention in this (or any other) instance. To claim that Italy has acted unfairly because it gains benefits without contributing to the maintenance of those benefits is to beg the question. To justifiably claim that Italy has acted unfairly, what we first need to know is whether Italy has a moral duty to comply with the rules of treaty making (and keeping).

\footnotetext{
${ }^{50}$ This is recognized in some formulations of the 'free-rider problem'. Richard Arneson, for example, states that "those who contribute their assigned fair share of the costs of the scheme have a right, against the remaining beneficiaries, that they should also pay their fair share" (Arneson 1982, 623 emphasis added). We must be able to assign a fair share before invoking the charge of free-riding against a noncontributor.
} 


\section{Intergenerational free-riding}

An argument very much like the free-rider argument has been made by Janna Thompson with respect to intergenerational treaty commitments. Thompson is concerned with the question of why we, as contemporary citizens of a state, should accept that we are bound by the terms of treaties signed before we were born and why we should consider ourselves bound to make reparations for historic treaty violations. For Thompson, in entering into treaties we commit ourselves to the rules of the practice of treaty making. When we want to bind our own successors (through a treaty) we must accept that we, in turn, are bound by our predecessors' treaty commitments. If we expect our successors to make good on our failures to comply with our treaties, we should accept that we must make good on our predecessors' past failures (Thompson 2002, 15 - 18).

Treaty as Humean Promise seems, on the face of it, to offer an account similar to Thompson's. If we want our own future oriented commitments to be taken seriously by our treaty partners, we need to demonstrate that we take seriously commitments made by our predecessors. However, Thompson rejects the kind of prudential considerations upon which Treaty as Humean Promise is based (ibid, 17). For Thompson, the obligation to honour a treaty must be a moral obligation. Our moral authority to bind our successors, to say that they ought to comply with the agreements we make, comes from accepting the obligation to honour the (morally acceptable) treaty agreements we have inherited. As Thompson puts it, if "you assign...obligations to others, then you have to be prepared to accept the same (or relevantly similar) duties yourself" (ibid, 16).

Now, Thompson does not explicitly state that the wrong of refusing to be bound by past commitments is the wrong of free-riding. Nevertheless her argument is similar and is question-begging in the same way in which the free-rider argument is question-begging. 
On Thompson's account, by violating historic agreements we try to claim the moral authority to bind our successors (thus claiming the benefits) whilst refusing to accept the costs imposed by this practice. Like the free-rider argument, her argument turns upon assumptions about the proper distribution of the responsibility to honour a treaty. She relies upon the assumption that the moral responsibility to honour a treaty falls equally on present and future generations.

As David Miller points out, however, Thompson's justification for a moral responsibility to honour the treaties of our predecessors assumes that our successors have a moral responsibility to honour the treaty commitments we make. But whether our successors have this moral responsibility is precisely what we want to establish (Miller 2007, 143146). Thompson needs an independent argument to successfully allocate the moral responsibility which future generations have to comply with our treaties. Without it she assumes, but does not establish, a moral responsibility incumbent on future generations to honour the treaties of their predecessors. Her argument begs the question.

In both the straightforward free-rider argument, as applied between different states, and Thompson's intergenerational version of it, the real normative work is being done by an independent account of the duty to honour a treaty. Receiving collective benefits without contributing is only morally wrong if it can be shown that, in doing so, the purported freerider is eluding an already established moral duty to contribute.

\section{Distributing duties}

We return, then, to our point of departure. We wanted to know whether there was a moral obligation to comply with a treaty. The 'danger and uncertainty argument' claims that there may be, but only in some, limited circumstances. The free-rider argument, which 
attempts to extend the moral obligation beyond these limited circumstances, presupposes that we can identify a prior moral responsibility to comply with treaties. But it is just this moral responsibility, in the form of a moral obligation, for which we were looking in the first place.

Of course, we may well hold that Italy does shirk a moral responsibility to comply with its treaties when it violates the Agreement on Cooperation in the Field of Tourism. Although 'danger and uncertainty' are very unlikely to result from Italy's violation, not every state can violate its treaty commitments. At least some, perhaps most, states must resist the temptation of violating their treaties on most occasions. But, of course, this does not tell us upon which states the responsibility for treaty compliance must fall. Italy, as we have seen, claims, through its actions, that the responsibility does not fall upon it, at least in this example. But there does not seem to be any reason why it should be Italy, rather than Brazil (or France, or Vietnam, or Canada, or whoever) that should be permitted to violate its treaty.

Rather than the 'danger and uncertainty argument' or the free-rider argument we might here appeal to a 'parity of reasoning argument.' If Italy believes that it is morally permissible to violate its treaties then, by parity of reasoning, Italy must acknowledge that it would be morally permissible for Brazil (or France and so on) to violate its treaties. But if every state violated its treaties the mutual trust between states would deteriorate. In the absence of some relevant difference between Italy and other treaty making entities, it is plausible to think the responsibility to comply with treaties must fall evenly on all treaty makers.

However, if our main concern is to ensure the maintenance of the social convention of treaty making, and mutual trust between states, we might discover that the best way of 
maintaining the social convention may permit some amount of treaty violation. That is, we should not assume that the most appropriate distribution of responsibility for treaty compliance is equally, across all treaty makers. For example, it may make sense to hold larger and more powerful states to higher levels of responsibility than smaller and less powerful states given the amount of damage that the former can do. Alternatively, the responsibility to comply with a treaty may be excused sometimes in order to better preserve the integrity of the conventional rules as a whole or to better realise the purpose served by that convention.

Take, for example, the principle rebus sic stantibus ('things thus standing'). This is a widely accepted principle in international affairs that permits state parties to terminate their treaty commitments when circumstances between the time of signature and the present have changed in some fundamental way. For example, the former East Germany invoked the principle to repudiate its treaty obligations under the Warsaw Pact in 1990. The identity of East Germany was due to change as it reunified with West Germany. The USSR, the main power behind the Pact, was also about to change identity. The military, geopolitical situation had rapidly and fundamentally altered (Waldron 2005168 - 169). In these kinds of circumstances the responsibility to comply with a treaty is plausibly excused.

One way of justifying rebus sic stantibus is as a means of preserving the integrity of the conventional rule that treaties must be kept. This is how the International Law Commission (ILC) understands it. Although they are talking about international law, what the ILC says applies as well to the conventional rules regulating state behaviour. The ILC observed that "if international law provided no way to terminate an unduly burdensome treaty, it is likely that parties would take action outside the law" (ILC quoted in Waldron 
$2005,167)$. In other words, if the rules did not permit violation, states would, most likely, violate burdensome treaties anyway. By permitting states to evade the responsibility to comply with treaties in certain circumstances we might better hope to protect the integrity of the rule requiring general treaty compliance..$^{51}$

With the aim of preserving the integrity of the general rule that treaties must be kept in mind, consider how rebus sic stantibus is stated in Article 62 of the Vienna Convention on the Law of Treaties:

"A fundamental change of circumstances... not foreseen by the parties, may not be invoked as a ground for terminating or withdrawing from the treaty, unless (a) the existence of those circumstances constituted an essential basis of the consent of the parties to be bound by the treaty; and (b) the effect of the change is radically to transform the extent of the obligations still to be performed under the treaty" (cited in Harris 1991, $799-800)$

The language used is negative ("may not be invoked") and the rule is very qualified (Waldron 2005, 168). This makes perfect sense if the aim is to preserve the integrity of the rules (whether conventional, legal, or both) of treaty making and keeping. Some

\footnotetext{
${ }^{51}$ The ILC are understandably careful to limit the exceptions to "unduly burdensome" treaties. The concern is that rebus, although intended to preserve the integrity of the rules requiring treaty compliance, would, in fact, undermine those rules by giving the gloss of legitimacy to attempts to escape from merely inconvenient promises as critics of the exception have long pointed out (see van Bynkershoek 2002, 284; Carty 2003, 832).
} 
states, in some circumstances, then, will be able to justify violation of their treaties. This may be permissible, under the rules, precisely in order to best sustain those rules.

So, on the view sketched above, whether East Germany evaded a responsibility to comply with the Warsaw Pact does not turn upon whether East Germany was a free-rider and only indirectly on the question of whether its actions undermine the useful conventional rules of treaty making. The extent of East Germany's moral responsibility turns upon the answer to the question of which division of responsibilities is best for maintaining the useful conventional rules of treaty making.

\section{The expectations account}

We have just looked at accounts of the wrong of treaty breaking that locate the wrong in the wrong of undermining or free-riding upon a useful social convention. A common criticism of these accounts, when applied to promises between individual persons, is that they locate the wrong of promise breaking in the wrong place. When I break a promise that I have made to you, I seem to wrong you specifically. I do not wrong everyone whose work has built and maintained the useful social convention. It is you to whom I seem to owe an apology. I do not owe an apology to every user of the social convention. Even if others are justified in complaining that I have undermined or free-ridden upon their efforts, this does not seem to capture what is central to what makes promise breaking wrong (see Melden 1977, 89 - 90; Scanlon 1998, 316; Kolodny and Wallace 2003, 125; and Pratt 2007, 559 - 560). According to critics, then, we need to add some account of the wrong done to the promisee specifically.

One way of accounting for the wrong done to the promisee is to claim that in breaking a promise, the promisor wrongfully disappoints the deliberately cultivated expectations of 
the promisee. Promises invite trust and such trust is valuable to the promisee in some way. By breaking a promise, and betraying that trust, a promisor harms the interests of the promisee (Habib 2014, sec. 5.5).

For some philosophers the promisee must experience a palpable harm in order for us to say that a wrong has been committed. For example, imagine I promise to deliver the parts you need for your car by Thursday. As a result you do not buy the parts for your car from an alternate supplier. On Thursday I break my promise. As you need the parts on Thursday you must go to an alternate supplier. But the price of the car parts has risen between the time of my promise and Thursday and you must pay more than you would have done had you not relied upon my promise. I have done a tangible harm to you by leading you to rely, to your detriment, upon my word (ibid; see MacCormick 1972, 62 73).

In contrast, some philosophers hold that the wrong done in inviting and disappointing your trust does not depend upon such palpable harm being done (Habib 2014, sec. 5.5). For these philosophers merely disappointing your expectation, irrespective of any further harm done to your interests, is enough to constitute a wrong. For Scanlon, for example, the value of promises lies in the value to promisees of being assured that something will happen even if they do not incur any costs as a result of their reliance (Scanlon 1998, $302-304)$.

\section{Treaties and expectations}

When a state enters into a treaty it seems to thereby create expectations in its treaty partners and, perhaps, in other groups and individuals. For example, in 1919 the Danish foreign minister assured the Norwegian foreign minister that Denmark would raise no 
objections to any claims Norway might make at the Paris Peace Conference to Spitzbergen in return for Norway not raising any objections to Denmark's claims over Greenland. Denmark claimed that it had been led to form expectations regarding Norway's actions that it was wrong for the latter to disappoint (Harris 1991, 736).

Note that Denmark and Norway did not sign a formal treaty. Nevertheless, Denmark claimed that the wrong was the same as that done by violating a formal treaty agreement. 52 Denmark, moreover, did not claim that Norway owed all states an apology for undermining or free-riding on the convention of treaty making. Denmark's claim was that Norway owed it to Denmark in particular to uphold the agreement. Norway acted wrongly by disappointing Denmark's reasonable expectations.

An expectations account of treaties can also sometimes be used to ground a moral obligation to comply with treaties concluded generations ago. Here, for example, is Will Kymlicka on historic treaties with minority groups:

"Historical agreements signed in good faith give rise to legitimate expectations on the part of citizens, who come to rely on the agreements made by governments, and it is a serious breach of trust to renege on them" (Kymlicka 1995, 119).

\footnotetext{
52 The plausibility of this claim, however, turns upon the extent to which the Norwegian government deliberately acted so as to raise Danish expectations. It is, after all, possible for others to form unreasonable expectations based upon our actions. Where there is a formal treaty there will be very good evidence of an intention by one party to raise the expectations of another. Where such evidence exists it is reasonable to attribute a high degree of responsibility for any harm done as a result of disappointed expectations to the party which violates the treaty. Nevertheless, a formal treaty is not necessary, according to the expectations account, for a moral obligation to be incurred.
} 
Acceptance of some version of the expectations account is not necessarily inconsistent with some form of practice-consequentialism. Here is Vattel again for example:

"He who violates his treaties... disregards the faith of treaties... and, so far as it depends on him, he renders it vain and ineffectual. Doubly guilty, he does an injury to his ally, he does an injury to all nations" (Vattel 2008, bk. 2 chap. 15, sec. 221, emphasis added). ${ }^{53}$

A treaty violator, according to Vattel, does at least two things wrong. He injures every other state and he also injures his treaty partner in particular.

A state might rely upon a treaty being fulfilled, in much the same way that you might rely upon me to deliver parts for your car in the example given above. The Danish government, for example, might complain that as a result of Norway's assurance of support, it did not lobby other states as hard as it otherwise would have done in the absence of the assurance. As a result, Denmark relied to its detriment on Norwegian assurances.

Sometimes, of course, there may be no tangible harm that results from a broken treaty. Parties to a treaty may not come to rely upon that treaty being kept until certain conditions have been met. So, for example, two states entering a treaty of military alliance against a third state may not need to rely upon the treaty being kept until such time as the third state begins to act aggressively. This may be many years, perhaps generations, after the treaty was signed. Perhaps, if they are lucky, they will never need to rely upon the treaty. For some, such as Russell Hardin, this suggests that "no one seriously thinks it wrong to abrogate a treaty if one at least gives timely public notice" (Hardin 2007, 130).

\footnotetext{
${ }^{53}$ Hume, in fact, says much the same though not about treaties specifically (see EPM App 3, 310).
} 
Even if there is no tangible harm resulting from a violated treaty, treaty violation may still constitute harm if we think it is wrong to invite, and subsequently disappoint, the trust of others. The challenge, then, becomes one of identifying the kind of harm that has been done. With respect to treaty violations this is complicated, as we shall see momentarily, by the fact that a whole range of different groups and individuals can come to form expectations as the result of a treaty.

\section{Circularity?}

Expectation accounts of promising are subject to a charge of vicious circularity. What we need to account for is the reason that the promisor gives herself by making a promise. According to expectations accounts, the promisor has a moral reason to keep the promise insofar as she leads the promisee to form the expectation that she will keep the promise. But how is making the promise, as such, supposed to achieve this end? One way is by the promisor successfully expressing her awareness that she has a moral obligation to honour the expectations she generates by making the promise. But she only has this moral obligation insofar as she successfully provides the promisee with the assurance that she will honour those expectations. She does this by expressing her awareness that she has a moral obligation to honour the expectations of the promisee. But, of course, the promisor only has this moral obligation insofar as she provides the promisee with assurance that she will honour the promisee's expectations, and so on (see Scanlon 1998, 307).

One answer to the charge of circularity is to appeal to some independent reason which the promisor has to keep the promise. But it is not clear what that reason might be. In many cases the promisee knows that the promisor lacks a prior reason to act in a certain way. That is why the promisee seeks additional assurance from the promisor in the first 
place. One of the jobs that a promise is supposed to do is to offer assurance, and raise expectations, when other reasons for doing what is promised are lacking (ibid, 322).

However, the circularity concerns are not troubling if we accept the Humean account of promising (and treaty making) outlined in the previous two chapters. The Humean account, as we have seen, suggests that the existence of an independent social convention of promising, and the generation of self-interested reasons to maintain access to that convention, can, at least in many instances, give promisees the assurance that they are after. ${ }^{54}$ With such an account in place we can explain how promises as such can generate expectations in promisees.

Extending the expectations account to treaties, then, there is no reason why we cannot say that the wrong of disappointing the expectations of treaty partners does not give treaty makers some additional moral reason to comply with their treaties. If we accept Treaty as Humean Promise, we need not worry about circularity.

\section{Whose expectations?}

When I make you a promise I raise your expectations that I will do what I have promised. I might also raise other people's expectations insofar as they know that I have promised you that I will act in a certain way. However, I am not usually thought to be responsible for their disappointed expectations although I am responsible for your expectations.

\footnotetext{
${ }^{54}$ This will not be acceptable to everyone who endorses the expectations account. Scanlon, for example, cannot appeal to this because he rejects the claim that social conventions are essential to generating the moral obligation to keep a promise.
} 
When Denmark complains that Norway has disappointed its expectations, whose expectations have been disappointed?

Denmark's complaint against Norway came from the Danish government. So we could say that the expectations of the Danish government have been disappointed by the Norwegian actions. Furthermore, the Danish government acts on behalf of the Danish people and, in order to do this effectively, it must make decisions based upon its assessment of the international circumstances in which Denmark finds itself. By deliberately leading the Danish government to expect that it will do something that it does not do, Norway falsifies the basis upon which the Danish government makes its decisions. ${ }^{55}$

Treaties do not only raise the expectations of foreign governments. They can also raise the expectations of other groups and individuals. Faced with a free-trade agreement companies may alter their business practices in order to take advantage of the terms of the agreement. A treaty whereby a state permits foreign workers to settle and work within its territory may lead individual people to undertake great costs, financial and emotional, to leave their homeland and settle in a new state. Companies and individual people, then, can come to form expectations on the basis of treaty agreements just as much as governments can. Treaty violations can disrupt the plans and lives of businesses and individuals.

\footnotetext{
${ }^{55}$ How important we think that this fact is will depend, in part, on what we make of the autonomy argument, discussed below. The claim that the wrong of promise breaking is the wrong of falsifying the basis upon which the promisee makes her decisions can be found in Dworkin $(2011,306)$.
} 
Insofar as a treaty is made between states, the expectations of companies and individual people, however reasonable, may seem to be analogous to the expectations of third parties regarding the promise that I make to you. A state may be responsible for the expectations of a foreign government, which acts on behalf of a state, but not the expectations of those to whom it did not make a promise. However, there are reasons to think that the expectations of companies, individuals, and other groups should be considered when determining whether or not a state has a moral obligation to comply with a treaty.

Firstly, we can point to the way in which the expectations account grounds the moral obligation to keep a promise. There are, after all, lots of ways in which agents can lead others to form expectations regarding their future behaviour. Those expectations may subsequently be disappointed. What remains an open question is to what extent the agent doing the disappointing can reasonably be held responsible for harm done to those she disappoints.

For example, I might make you a promise knowing full well that other people will also come to rely upon me keeping my promise even though I did not make the promise to them. If I break the promise I disappoint their expectations. The question is, to what extent am I responsible for their disappointed expectations? The answer to this will turn upon the extent to which I intended my promise to lead them to form their expectations, the costs to me of keeping my promise, the steps that they could have taken to avoid disappointment, and so on (Dworkin 2001, 306 - 307).

Now, things seem less clear cut than they do with respect to my responsibility for disappointing your expectations. After all, I made you a promise. Nevertheless, it may, in the circumstances, be reasonable to hold me partly or even fully responsible for the 
disappointed expectations of those to whom I did not make a promise. Likewise, a treaty may give rise to expectations in third parties which it would, in principle, be wrong to disappoint even if the treaty was not made with them directly. That it is reasonable to hold treaty makers responsible for the expectations of other groups and individuals is suggested by what follows.

Secondly, many treaties are intended to affect the decisions, lives, and prospects of individual people and other, non-state, groups. Free-trade agreements, for example, may be intended to make the states involved wealthier but in order to achieve this aim, individuals and companies must take advantage of the opportunities afforded by the agreement. Insofar as treaties regulate much of international affairs - from air travel to international banking - they have an impact on the lives and livelihoods of a wide variety of actors, far more so than most promises between individual persons do. It is reasonable, then, to consider the expectations of more than state parties to a treaty when attributing the moral responsibility to comply with a treaty.

\section{Conflicting expectations and the passage of time}

Treaties are often intended to last for considerable periods of time, perhaps generations. New Zealand's Treaty of Waitangi was signed between the British Crown and Māori chiefs in 1840 for example. Since then there have been a number of cases of treaty violation with land, in particular, being taken from Māori owners and given to settlers (contrary to Article 2). Now, the original Māori owners and, perhaps, their descendants would have formed expectations, as a result of the treaty, which were subsequently disappointed. The expectations account, offered above, can help to explain what was wrong with violations of the Treaty of Waitangi (see Kymlicka 1995, 119). 
Insofar as wrongly appropriated land is still not held by the descendants of the original owners such land seems to be held contrary to the terms of the treaty. The treaty, then, might be used as a basis to decide whether or not land wrongly appropriated in the past should be returned to the descendants of the original owners today.

However, new expectations can form over time. A history of treaty violations may have led descendants of Māori to expect that the Crown would not make good on its treaty commitments in the future. Likewise, the descendants of the settlers who took the land and passed it on (or sold it) through generations, may have formed expectations about the continued ownership of that land (see Waldron 1992, 18 - 19).

My point is not to decide the matter with respect to the situation in New Zealand but, rather, to note that a history of treaty violations can give rise to significant expectations just as much as can entering a treaty in the first place. There may be expectations formed as a result of a treaty but, in certain circumstances at least, there may also be expectations that have formed amongst a variety of agents based upon behaviour by subsequent governments contrary to the terms of the treaty. Where many generations have passed, in particular, we cannot simply assume that the expectations grounded in the treaty will automatically trump the expectations formed as a result of repeated treaty violations. The reasonableness of expectations grounded in a treaty may fade with time.

\section{Treaties without expectations}

Not all treaties will give rise to expectations. Indeed, not all treaties need be intended to give rise to expectations in others. Imagine the following case. The USA enters a treaty with North Korea whereby the latter promises to give up its nuclear ambitions. The USA, however, does not expect North Korea to comply with the treaty. In fact, they expect 
North Korea not to do so and this is why they entered the treaty. They want to show China that North Korea cannot be trusted. The USA is using the treaty for political ends and not to gain assurance about North Korea's future actions. ${ }^{56}$

Now, the USA can use the treaty with North Korea for these purposes partly because North Korea has shown itself to be unreliable in the past. But imagine that North Korea is now sincere about ending its nuclear ambitions, just as South Africa was following the end of Apartheid. No-one expects North Korea to comply with the treaty. According to the expectations account, North Korea seems to lack a moral obligation to comply with a seemingly perfectly good treaty. In cases such as that of North Korea, the expectations account must either say that there is no moral obligation to comply with the treaty or come up with some alternative account of the moral obligation (such as the moral wrong of undermining the convention) (Habib 2014, sec. 5.7).

The expectations account can be used to account for moral reasons to comply with treaties. Treaty as Humean Promise is perfectly compatible with an expectations account and is not subject to the circularity concerns to which such accounts are vulnerable. However, perfectly valid treaties need not give rise to expectations and hence need not create moral obligations grounded in those expectations.

\footnotetext{
${ }^{56}$ Consideration of a similar case can be found in $\operatorname{Raz}(1977,213)$.
} 


\section{The value of political autonomy}

The final way of thinking about the moral obligation to comply with a treaty that I want to explore refers to the value of autonomy. A number of philosophers ground the obligation to keep a promise in the importance of respect for individual autonomy (Fried 1981; Raz 1986; and Shiffrin 2008, 500). By making promises I exercise my autonomy insofar as I freely determine obligations for myself. It is valuable to each of us, on this view, that we be able to transfer some authority over some of our actions to one another if we so wish (see Sheinman 2011c, 22). As Charles Fried puts it;

"In order that I be as free as possible, that my will have the greatest possible range consistent with the similar will of others, it is necessary that there be a way in which I may commit myself. It is necessary that I be able to make nonoptional a course of conduct that would otherwise be optional for me" (Fried 1981, 13).

The promisee has the right to demand performance of my promise (or waive it if she so wishes). To hold me to my self-imposed obligations is, on Fried's view, to show respect for my autonomy, that is, to take seriously my capacity to determine, for myself, my own goals (ibid, 20). In keeping my promise I also show respect for the autonomy of the promisee to whom I have granted temporary authority over some of my actions.

Such an account of the value of promise making is, in principle, quite consistent with the Humean picture of promising and might be added to it. On the Humean picture, recall, the value of promising lies in its ability to facilitate coordination and realise mutually beneficial cooperation. To this, defenders of the autonomy thesis, such as Fried, can add that promising, and promise keeping, is valuable because it also shows proper respect for the autonomy of the agents involved. 


\section{Future options and respect for autonomous choices}

We must distinguish between two claims. The first is that making promises can increase the future options (and thus autonomy) for those that make the promises. In this way, Hume's two farmers may be understood as exchanging promises so as to increase their future options. By helping one another, thus harvesting all of their corn, the farmers plausibly have available a greater range of options for the future than they would have had, had they both failed to harvest their corn. They achieve this, as Fried suggests, by reducing their short-term options for action.

The second claim is that a promisor should keep her promise because she has freely chosen to make it. That is, in making a promise it is her exercise of autonomy that is morally important and which creates the moral obligation. Making a binding promise may or may not also increase her future options for action. If Anita, by exercising her autonomy, promises to help Bob harvest his corn then Anita ought to help Bob harvest his corn even if she subsequently discovers that helping Bob will in fact reduce her future options for action.

\section{Treaties and autonomy: Grotius and Goodin}

We can illustrate the previous two claims by reference to treaty commitments. Take, for example, a disagreement between Hugo Grotius and Robert Goodin about whether treaties of cessation should be considered binding or not. For Grotius, just as individual persons can make binding promises to enslave themselves so, too, can sovereign groups

make binding treaty promises to cede sovereignty in perpetuity (Grotius 2005, bk. 1, 
chap. 3, sec. 8; see Goodin 2000, 318). ${ }^{57}$ If they exercise their autonomy in such a way then we should respect the decision that they have made. ${ }^{58}$

For Goodin, on the other hand, it is precisely because we should respect people's (and peoples') autonomy that we should refuse to accept, or respect, promises that would extinguish that autonomy in perpetuity as binding. It does not matter, on this view, if the decision to make the promise is freely made. It simply closes down too many future autonomous options for action for the agent (Goodin 2000, 321).

Like Grotius, Goodin draws upon an analogy between individual persons (and slavery promises) and sovereign groups (and cessation treaties) although, on the basis of this analogy, he develops very different conclusions. For Grotius we respect the political autonomy of the group ceding sovereignty by holding them to their treaty commitment. For Goodin, on the other hand, this is not to respect their autonomy at all. It closes down too many future options for action. Respect for the political autonomy of the group in question should lead us to consider the treaty non-binding.

\footnotetext{
${ }^{57}$ Grotius says that "as there are several Ways of Living, some better than others, and every one may chuse which he pleases of all those Sorts; so a People may chuse what Form of Government they please" (Grotius 2005 bk. 1, chap. 3, sec. 8). A treaty of cessation entered by a ruler who lacks the proper authority to do so, however, is not considered by Grotius to be binding (ibid, bk. 2, chap. 4, sec. 12.2 and bk. 2, chap. 15, sec. 16).

${ }^{58}$ See, also, Kymlicka's discussion of treaties of cessation in the Canadian context. Political autonomy for certain groups (such as indigenous peoples) can be justified, Kymlicka thinks, by reference to the treaties they chose to enter into (Kymlicka 1995, 117).
} 


\section{The apparent plausibility of the analogy between political and individual}

\section{autonomy}

Notwithstanding such differences, claims about the importance of autonomy seem to translate well into international affairs. We can, and do, talk about the autonomy possessed by states. By this we typically mean something like the political capacity possessed by states to create their own laws and to be independent of other states. Often we refer to the sovereignty of states. Sovereign states, we might say, can set their own domestic policies and pursue their own goals, at least within certain limits (see, for example, Rawls 1999, 38, 61).

Of course, the question of precisely which decisions may rightfully be left to states is disputed. There are plausibly some things that states ought to do, or refrain from doing, irrespective of their treaty commitments. Still, it is plausible to say that there are some policy areas that properly fall within the purview of each state. So, for example, we might say that Canada can rightfully set its own agricultural policy or set tax revenue levels and so on. Nevertheless, these are cases in which states, like Canada, have entered into treaties which seem to limit their sovereign prerogative.

Insofar as treaties limit sovereignty it may sound strange to say that they can also serve to further the autonomy of states. For some theorists, like Georg Jellinek, binding treaties amount to "an unacceptable surrender of sovereignty" (Jellinek, cited in Wehberg 1959, 778). Sometimes decision-makers in states are wary of ratifying treaties precisely because doing so would represent a limit on the exercise of future state sovereignty. For example, the Convention on the Rights of the Child has been adopted by every state except 
Somalia, South Sudan, and the USA. One reason that the US Senate has refused to ratify the Convention is that doing so would limit the sovereignty of the USA. ${ }^{59}$

Most treaties appear to limit state control in some area or another. Take the dispute between the EU and the USA over the former's ban on the importation of hormone treated beef from the latter. The WTO agreement limits the authority claimed by the EU to determine its own agricultural policy. The WTO agreement is, we might say, autonomy reducing from the perspective of the EU with regards to this issue.

We might, of course, hold that the EU ought to comply with its WTO agreements because it freely chose to enter into those agreements. That is, it exercised its autonomy and transferred its authority to decide whether or not hormone treated beef is permitted into the territory of the EU to the USA. The USA can thus choose to exercise this authority (or not) and in so doing respects the autonomous choice of the EU. Furthermore, if the EU fails to comply with the treaty it might be accused of failing to respect the autonomy of the USA by not respecting the authority which it freely granted. Such considerations appear to apply despite any calculations regarding the number of options treaty compliance opens up for the parties involved.

As the disagreement between Grotius and Goodin suggests, the plausibility of considering treaty violation morally objectionable because it violates a right of autonomy belonging to a state is typically understood to rest upon an analogy between individual persons and states. On the basis of this analogy, we should hold the EU to its promises for the same

\footnotetext{
59 'Why won't America ratify the UN convention of children's rights?' The Economist, available at http://www.economist.com/blogs/economist-explains/2013/10/economist-explains-2 (accessed 10/ 09/ 2014).
} 
reasons that individual persons should be held to their promises. That is, it is important to respect the autonomy of agents for its own sake (and irrespective of whether doing so results in a wider range of total options for the agent; at least to a point, such as the slavery promise discussed by Grotius and Goodin). Agents who make promises might be thought to have an autonomy based reason to keep their promises in addition to the kind of prudential considerations noted by Treaty as Humean Promise.

Keeping one's promises is an important part of being an autonomous agent. Nevertheless, however plausible this view is for individual persons and their promises, the analogy between individual and state autonomy is imperfect. State autonomy, I shall suggest, is merely instrumentally valuable in a way in which the autonomy of an individual person, which has intrinsic value, is not. The autonomy account, applied to states, is actually just another way of spelling out the kind of prudential considerations noted by Treaty as Humean Promise.

\section{Individual persons}

In George Eliot's Middlemarch, Dorothea is married to the older and ailing Edward Casaubon. ${ }^{60}$ Casaubon is concerned about Dorothea's feelings for Will Ladislaw, his younger cousin and wants to ensure that Dorothea will continue his life's work after he has died, a project that Dorothea has come to view as pointless. In an attempt to limit Dorothea's future actions after his death, Casaubon tries to get Dorothea to bind herself with a general promise to "carry out [his] wishes... and apply [herself] to do what [he] should desire." Dorothea is, understandably, reluctant to make a promise where she is

\footnotetext{
${ }^{60}$ For a fascinating look at George Eliot's views on promising see Ganz 2008. For a discussion of Dorothea and Edward Casaubon see pages 579 - 580 .
} 
"ignorant what it will bind [her] to" and says that her affection for her husband will be sufficient to lead her to do the right thing. Casaubon, however, wants a stronger commitment than this. He wants her to obey his judgment. Dorothea is torn between the desire to comfort her husband and a fear of committing herself to carry out his unspecified wishes (Eliot 1998, 449 - 451).

Dorothea's concerns about Casaubon's demands are similar to those raised by Goodin with regard to the slavery promise. Her promise may simply close down too many future options for Dorothea to be conscionable. But why does she take the promise so seriously? Why not comfort Casaubon by making the promise (however unreasonable) and then subsequently break it once he dies? One reason is, of course, suggested by the Humean account of promising outlined in previous chapters. Dorothea has some self-interested reason to keep her promise having made it. But this does not seem a very strong reason in this kind of case, at least if Casaubon's demands are as demanding as Dorothea fears they will be. Furthermore, Dorothea knows that the private and taciturn Casaubon would not make public the private promise between the two of them. Dorothea could plausibly 'get away' with breaking her promise.

We can, I think, understand Dorothea's reluctance to promise even though she could reasonably hope to escape the penalty of not being trusted by others in the future. Dorothea's refusal to make a promise is an assertion of her own sense of self and of control over her own life. That is, Dorothea asserts her autonomy. Making the promise to Casaubon threatens this control precisely because promises are one way of exercising that autonomy. As an autonomous agent, Dorothea takes seriously her own past commitments (see ibid, 506 - 507). Her commitments, including her promises, are used to give shape to her life. Dorothea's sense of self is closely connected with her taking 
responsibility for her commitments. As Philip Pettit puts it, to waver in the face of past commitments, to refuse to accept them as hers, is to view her own life as an outsider might (Pettit 2001, 80 -90).

Of course, we might feel that Dorothea's standards are too high in this case. She is, perhaps, too demanding. As Goodin argues, some commitments may just constrain too many options to be considered binding. Nevertheless, Dorothea's sense of conflict makes sense. It is psychologically plausible. Someone who routinely fails to live up to her commitments, or take responsibility for her failures, because she does not accept them as her own, seems to lack an autonomous sense of self persisting through time. Insofar as we have an interest in being autonomous agents we have an interest in being able to make our own commitments to give shape to our own lives and, as Fried claims, an interest in being held to those and expected to live up to them.

\section{The autonomy of states: vicious states}

However plausible such an account is for individual persons like Dorothea, our concern is with certain kinds of groups, in particular states. It might seem clear that autonomy for a state is not the same thing as autonomy for individual persons like Dorothea. It is often urged that the autonomy claimed on behalf of a state can, after all, be used to illegitimately limit the autonomy of individual persons within that state (Beitz 1979, 71 - 83; Teson 1998, 60 - 64). For example, the Chilean state systematically 'disappeared' thousands of

Chileans following Pinochet's coup in 1973. The autonomy of action claimed by the Chilean state was directly opposed to the autonomy of many of its citizens.

On the face of it, such examples need not seriously dissuade someone who wants to argue that the autonomy of states, as such, is closely analogous to the autonomy of individual 
persons. Someone who claims that the autonomy of individual persons is morally important is not committed to the claim that an autonomous person is permitted to act entirely as she pleases. Likewise, we might say, the truly autonomous state is not permitted to act as it pleases and at the expense of its own citizenry. In short, if someone holds that autonomy applies to both individual persons and states alike, they need not be any more embarrassed by the existence of vicious states than they are by the existence of vicious persons. $\underline{61}$

On the other hand, vicious persons can make and keep, and be expected to keep, perfectly good promises. A person who is cruel to his family is reprehensible in many respects but can be punctilious in keeping his promises to others. Likewise, a cruel and vicious government can make and routinely keep its treaties. However, the vicious individual makes promises only on his own behalf (although his promises might, of course, have

\footnotetext{
${ }^{61}$ Here, and elsewhere, I may give the impression that I consider there to be a clear distinction to be drawn between 'vicious' states on the one hand (say, for example, North Korea) and 'virtuous' or 'altruistic' states on the other. Moreover I may give the impression that I think that liberal democracies are the only states which fall into the latter category. I should note that I do not think that the type of regime that a state has (whether liberal or non-liberal) need tell us anything about whether that state is morally good or, indeed, is liable to keep its treaty commitments. I also do not think that the world divides neatly into 'virtuous' and 'vicious' states (liberal or otherwise) although some philosophers do come close to thinking just that (see, for example, Teson $(1998,25)$ ). It is almost certainly true, as one of my examiners pointed out to me, that there are no perfectly 'clean' (or virtuous) states or perfect democracies. My aim in introducing the distinction was to suggest that the analogy between autonomy for individual persons and for states is imperfect even if (which may not actually be the case) we hold there to be a clear-cut distinction between virtuous (liberal) states and vicious (illiberal) states. I would like to thank Lisa Ellis for pointing out that I appear to be endorsing a distinction which I never intended to endorse.
} 
consequences for others). The vicious government claims to speak on behalf of the state, and the present and future citizens of that state. It claims the right to make promises for the state. So, the vicious government might enter, and keep, treaties that will further entrench the power of that government against its own citizens, or enrich individual members of the government or their cronies. But insofar as it maintains its position through the use of coercive force we will feel uneasy about the claim that its promises really are binding on the citizens on whose behalf it claims to speak.

One response to such concerns is to claim that states, and other political societies, must fulfil certain minimal universal moral requirements if they are to legitimately claim the autonomy, and right to enter treaties, which they currently claim. We might require, for example, that the authority claimed by the institutions of the state must rest, in some sense, upon the consent of the governed and respect for individual human rights. For example, Fernando Teson argues that states that do not have functioning democratic systems and do not respect individual human rights have no right to claim that their treaties be honoured by other states (Teson 1998, 46). It is difficult, however, to determine precise and widely acceptable criteria for when a state can legitimately claim to make binding treaties. Teson's focus on functioning democratic systems and respect for human rights rules out states like North Korea but also, most probably, current major powers such as Russia, China, or Iran. To exclude such states from the right to expect to have their treaties honoured threatens the kind of useful, stable, cooperation between states that is part of the purpose of treaty making.

Finding a balance between the rights of political societies to live by their own laws and the obligation on those societies to respect certain universal moral requirements is a hard task. The existence of vicious governments who claim the right to enter treaties on behalf 
of the very people they oppress is troubling. There are, however, many states that seem to meet criteria less demanding than those proposed by Teson. The governments of these states, although illiberal in many ways, do not oppress minority groups. Most citizens of the state accept that the institutions of the state possess the authority to make collective decisions on their behalf (even if they do not agree with every single decision made) (Thompson 2002, 33). Nevertheless, the autonomy claimed by some governments on behalf of their states may, ultimately, be of little or no moral worth. Ultimately, a full account of the value of political autonomy will be parasitic on an account of political legitimacy. In this sense the analogy between individual and state autonomy breaks down.

Let us turn, now, from despotic states to a benign, liberal, and democratic one. If the analogy between the value of autonomy for individual persons and states is problematic with respect to non-liberal states, perhaps it will prove less problematic for liberal and democratic ones.

\section{The autonomy of states: benign, liberal, and democratic}

Take the citizens of an imaginary liberal democratic state, Democratia, who are deciding whether to comply with a treaty requiring them to allow hormone treated beef into their country. Imagine, for the sake of simplicity, that fifty years previously a majority of the citizenry had voted to enter a treaty requiring them to permit hormone treated beef into the country and that, according to their voting procedures, this was sufficient to ratify the treaty. Now, fifty years later, they must decide whether to honour the treaty or not.

The same kind of considerations that led Dorothea to take her commitments seriously may lead the citizens of Democratia to honour the treaty commitments entered into fifty 
years previously. Just as Dorothea sees it as important to own and endorse her earlier commitments, to see them as her commitments, so, too, might the citizens of Democratia endorse their earlier, collective, commitments. Dorothea can honestly say: "I made that commitment". The citizens of Democratia might say: "we made that commitment."

But the composition of Democratia will likely have altered in the fifty years since the commitment was made. Some individual members of Democratia will have died. Many others, too young to vote, or not even born, fifty years previously, will now be entitled to vote. They might question why they should be bound by commitments they did not make. Insofar as the group of citizens has changed it may seem to them reasonable for them to deny that the group, as it exists now, is the same as the group as it existed fifty years prior. Dorothea understood her commitments as binding herself. So long as she understood herself as existing through time, she had reason to respect and honour those commitments and in so doing her status as an autonomous agent. The citizens of Democratia, on the other hand, deny this identity. Their autonomy, they feel, is compromised, rather than enhanced, by considering themselves bound by the commitments of the past.

Now, insofar as citizens of Democratia are members of a well-functioning state they may, without being inconsistent or confused, choose to understand their group of citizens as being the same as the group as it existed fifty years earlier. But why would they choose to view themselves in this way rather than as a new, autonomous citizenry who happen to be members of the same state as their forebears? For Dorothea, we saw, viewing her past commitments as the commitments of someone else struck at her sense of autonomous selfhood and this gave her a reason to keep her promises even when it was inconvenient to do so. But it appears to be open to the citizens of Democratia to reject 
their past commitments without thereby undermining their present sense of identity in a way that did not seem open to Dorothea. For many contemporary members of Democratia, the citizenry of fifty years ago may well seem like a different group altogether.

Following an argument made by Philip Pettit we can note that contemporary members of Democratia do have some reason to view themselves as members of the same group as Democratia fifty years previously and so have reason to honour commitments made in the past. They have reason to want their behaviour as a group to be consistent with the past decisions, actions, and judgments of the group. They have this reason insofar as the group aims at effectively promoting some shared purpose. So a state, as a group, may, in a general sense, aim at the safety and prosperity of its citizens. In order to do this effectively they will enter into treaty commitments with other states. But if, over time, the state shows itself to be inconsistent and unable to live up to past commitments it will be hard for others, individuals and other groups, to take the state seriously (Pettit 2001, 112 - 113). These are, of course, the kinds of considerations noted as important by Treaty as Humean Promise. Insofar as the members of a state want to achieve goals as a group, they have reason to take seriously the past commitments of that group.

For Dorothea, promises are valuable as a way of giving self-imposed structure to her life. By making promises she creates her own commitments. By keeping her promises she endorses those commitments as her own. For the citizenry of a state, treaty commitments can be a way of giving self-imposed structure to a common life, together. By entering treaties a state exercises its autonomy and creates its own commitments. But the burden for keeping these commitments may fall on future generations who do not see them as their own commitments and see no need to live up to them. Insofar as viewing such 
commitments as their own is valuable for the future citizenry of a state it is instrumentally valuable. It is because they want to achieve other things together and because, in order to do this, the group to which they belong needs to be taken seriously as the kind of entity which upholds its commitments that they have reason to take seriously commitments made in their name.

So, although there is a sense in which a concern with their autonomy gives individual persons, like Dorothea, and groups, like states, a reason to honour their commitments, the analogy is not perfect. It is not merely useful for Dorothea to see herself as identical with her past self but, rather, doing so is a crucial part of her agency. In this respect Dorothea has a reason to honour her past commitments that groups have only insofar as doing so is important to achieving their future goals.

\section{Conclusion}

I began this chapter by noting that many people, whether philosophers, politicians, or jurists hold that there is a moral obligation to comply with treaties, at least all else being equal. Treaty as Humean Promise, with its focus on self-interested reasons to comply with a treaty, seems to lack an account of what this moral obligation might consist in.

Of course, that many people have the intuition that there is a moral obligation to comply with treaties does not mean that there actually is such an obligation. In this chapter I have suggested that it is a mistake to think that there is one, simple moral obligation to comply with treaties. To argue this I have discussed three common kinds of account of the moral obligation to comply with a treaty. These are the practice-consequentialist accounts, the expectations account, and the autonomy account. 
With respect to the practice-consequentialist accounts (the 'danger and uncertainty' argument and the free-rider argument), I suggested that some, but not all, treaty violations can be justifiably morally condemned because of the likely consequences of violation. The most plausible examples of such treaty violations are those that occur against a background of hostility and a willingness of parties to use force to back up their claims. The free-rider version of practice-consequentialism, on the other hand, seems to offer an account of the wrong of treaty violation which applies to all acts of treaty violation. However, whether or not treaty violation is wrong depends upon first establishing that the state in question has a responsibility to comply with the treaty. This is what the free-rider argument was supposed to establish.

The expectations account, on the other hand, locates the wrong of treaty violation in the deliberately cultivated, and knowingly disappointed, expectations of other parties to the treaty. However, it is not only the expectations of the (state) parties to the treaty that are morally relevant but, rather, the expectations of a wide variety of individuals and groups.

One apparent problem facing the expectations account is that it seems to be subject to a charge of vicious circularity. However, Treaty as Humean Promise offers a promising way out of this circularity. The expectations account can then be incorporated into a Humean account of treaties. However, not all treaties give rise to expectations in others.

Finally, I looked at arguments that located the value of treaty making, and keeping, in the importance to agents of exercising autonomy. States, like individual persons, might use promises as a way of creating a greater range of future options for action. But some treaties appear to close down such options for action. In the extreme we have the treaties of cessation discussed by Grotius and Goodin. But even less extreme treaties, such as 
those relating to the importation of hormone treated beef, plausibly limit the future autonomy of a state.

Another way of thinking about the value of autonomy, however, is to say that it is valuable for agents to shape their own lives and promising, whether it ultimately cuts down or opens up options, is one way of doing this. This is a plausible claim with respect to individual persons. I illustrated it with respect to the character of Dorothea in George Eliot's Middlemarch. However plausible it is for Dorothea, our concern is with treaty commitments. Although we talk of the autonomy enjoyed by political communities, the analogy between the autonomy of Dorothea and the autonomy of a state (whether vicious or benign) is imperfect. Ultimately, treaty compliance is valuable insofar as members of a group have reason to want their commitments taken seriously by others. Treaty compliance is instrumentally valuable and is so in much the same way that Treaty as Humean Promise claims that it is instrumentally valuable. 


\section{Chapter 4: Contract, Interdependent, and Normative Treaties}

In previous chapters I introduced Hume's story of the two farmers and extended it to international affairs. I then turned to look in more detail at two views I labelled 'Treaty as Promise' and 'Treaty as Humean Promise'. In the last chapter I addressed the apparent absence of moral considerations in the Humean account.

In this chapter I will distinguish between three different types of treaty. These are the contract treaty, the interdependent treaty, and the normative treaty. All three types of treaty come in bilateral or multilateral varieties. The chapter is divided into two parts. In part A I discuss contract treaties and interdependent treaties. In part B I discuss normative treaties. There are reasons to think that interdependent treaties and normative treaties are not really promises (Humean or otherwise). Nevertheless, I think that they are promises and explain why.

\section{Introduction}

This chapter turns to look at specific types of treaty. It distinguishes between three types of treaty. The chapter is divided into two parts. In the first part (A) I discuss contract treaties and interdependent treaties. One objection to Treaty as Humean Promise (and Treaty as Promise) is that many treaties, in particular what I shall call 'conditional contract treaties' and 'interdependent treaties', are, properly speaking, agreements. The objection goes that agreements are not promises and are not, properly speaking, comprised of promises. So, if many treaties are agreements then these treaties are not also promises, Humean or otherwise. I do not disagree that many treaties are agreements 
and that thinking about them as agreements is illuminating. But I suggest that this does not stop them being promises. Treaties and promises are, I suggest, different instances of the same kind of act: the self-imposition of a (self-interested) reason to do that which is promised.

In the second part (B) I discuss a relatively modern form of treaty, the so-called 'lawmaking' or 'normative' treaty. These treaties, roughly speaking, are intended to create general rules for the community of states including for those states that do not consent to the treaty. Such a treaty may not look very much like a promise at all if, as I have suggested, what is important about promises is that they involve self-imposed reasons to do that which is promised. I shall argue that these normative treaties are, indeed, promises. I do so by noting the distinction between different kinds of reason that an agent has to keep a promise. Nevertheless, I finish by suggesting that the treaty instrument may not be the most appropriate means by which to create general rules for the community of states. However, insofar as the treaty is the premier tool we currently possess to realise general rules for the community of states (or create international institutions which can realise the ends intended by those rules) we would do well to remember that promising to do something is not always the only, or even the most, important reason that agents have to do that which is promised. One of the virtues of Treaty as Humean Promise is that it makes this fact clear. 


\section{Sir Gerald Fitzmaurice}

In the 1950s, Sir Gerald Fitzmaurice, a Special Rapporteur for the International Law Commission (ILC), distinguished between three broad types of treaty. ${ }^{62}$ Although Fitzmaurice was concerned with the legal, rather than moral, character of treaties his classification remains a useful starting point for thinking about different kinds of treaties more generally. I set out the three kinds of treaty below. Before doing that I will briefly note the difference between bilateral and multilateral treaties.

\section{Bilateral and multilateral treaties}

Bilateral treaties are treaties that are entered into by two states. Let us take, as an example, a fairly simple bilateral treaty. In 1977 Hungary and the then state of Czechoslovakia concluded a treaty related to the joint utilization of the hydro-electrical potential of the Danube River, which also formed a border between the two countries. The treaty, the Budapest Treaty, required each party to construct a dam, the Hungarians at Nagymaros in Hungary and the Czechoslovakians at Gabčíkovo in Czechoslovakia. A bilateral treaty like this looks very much like the kind of contract, or joint promise, that two companies might enter into to exchange goods or that Hume's two farmers entered into in order to exchange their labour with one another. The two parties, whether

\footnotetext{
${ }^{62}$ Fitzmaurice's discussion can be found in the Second Report on the Law of Treaties (1957). Later, when I discuss normative treaties, I also refer to the Third Report on the Law of Treaties (1958). He sometimes calls 'contract treaties', 'reciprocating treaties.' 'Non-reciprocating treaties' include interdependent treaties and 'integral' treaties (which I call 'normative treaties', below). A good discussion of Fitzmaurice's work on treaties, which prompted me to use that work as a framework for my own discussion, can be found in Brölmann 2005, 383 - 403.
} 
companies, farmers, or states, can best realise some mutually beneficial end by cooperating on a shared project. To do this they reciprocally exchange certain rights or benefits with one another. A treaty may be used to secure this cooperation.

As we shall see later, however, not all bilateral treaties aim at the exchange of reciprocal benefits and rights between just two parties. For example, the Panama Canal Treaty (1977) is a bilateral treaty. The parties to the treaty are the USA and Panama. Although some features of the treaty revolve around the reciprocal exchange of rights between the two parties, the treaty also aims to create rights for third parties. The Canal, according to the treaty, "shall remain open to peaceful transit by the vessels of all nations on terms of entire equality."63

There is also the multilateral treaty. A multilateral treaty has more than two parties. Many modern treaties are like this. For example, the Geneva Conventions (1949) have 191 parties, whilst the International Convention against the Recruitment, Use, Financing, and Training of Mercenaries (1989) has 27.

As we shall see in a moment we can distinguish between three kinds of multilateral treaty although all involve more than two parties. Some multilateral treaties are, really, a compilation of bilateral relationships which, in principle, can exist independently of one another. This, incidentally, is the form that multilateral treaties usually took during the eighteenth century when Hume was writing about treaties. The Peace Treaty of Utrecht (1713), for example, should really be understood as a collection of bilateral peace treaties between the former belligerents. So, for example, Great Britain might enter into a treaty

\footnotetext{
${ }^{63}$ This is, in fact, contained in Article 2 of the 1977 Treaty concerning the Permanent Neutrality and Operation of the Panama Canal which accompanies the main treaty.
} 
of peace with Spain and another treaty, with the same terms, with the Dutch Republic. And the Dutch Republic would enter into another treaty, with the same terms, with Spain. In principle, Spain could violate part of the treaty with the Dutch Republic but maintain its treaty with Great Britain. More recently, Joost Pauwelyn has argued that the 1994 treaty founding the World Trade Organization (WTO) is best understood as a series of bilateral agreements (Pauwelyn 2003).

Not all multilateral treaties are composed of bilateral agreements. A multilateral mutual disarmament treaty, such as that agreed to at the Washington Naval Conference (1921) between USA, Great Britain, and Japan, will not typically comprise a series of different bilateral agreements. Instead all the parties will agree to one set of terms. ${ }^{64}$ Other examples of multilateral treaties that are like this include certain treaties dealing with human rights such as the Convention against Torture and other Degrading Treatment (CTDT) (1984). As we shall see in a moment there are some important differences between multilateral treaties that are a collection of bilateral agreements, multilateral treaties that are like disarmament treaties, and multilateral treaties that are like the CTDT.

Whether a multilateral treaty is comprised of bilateral agreements or involves one undertaking that all parties agree to can be important. We have already seen that one party could violate the Treaty of Utrecht without necessarily jeopardising its treaty

\footnotetext{
${ }^{64}$ The parties may, or may not, be permitted to enter 'reservations' towards certain aspects of the treaty. A reservation is a unilateral statement made by appointed representatives of a state whereby the state purports to alter or even exclude the effect of certain treaty provisions with respect to that state (see Article 2 of the Vienna Convention on the Law of Treaties (1969)).
} 
relationships with other parties. I say more about this kind of case below. It is also worth noting that a multilateral treaty that consists of bilateral agreements can, in principle, be renegotiated more easily than a multilateral treaty that consists of just one agreement between all states. This is because in the latter case the consent of all the current parties to the treaty would be needed as any change affects them all. In the former case two parties can alter the terms of their agreement without thereby affecting the agreement that they have with other parties to the agreement.

\section{Contract treaties, interdependent treaties, and normative treaties}

It is time now to look at Fitzmaurice's classification of different treaties. As we shall see there are, in fact, bilateral and multilateral versions of each type of treaty. The three types of treaty are 'contract' treaties, 'interdependent' treaties, and 'law-making' or 'normative' treaties. I shall begin by saying a little bit about contract treaties and interdependent treaties in Part A, below. In Part B I move on to normative treaties.

\section{A. Contract treaties and interdependent treaties}

\section{Contract treaties}

Contract treaties involve two, or more, parties to the treaty exchanging rights or benefits with one another. Although typically comprised of a number of different promises, contained in various articles, and thus often more complex than promises between individual persons, the contract treaty is closely analogous to the kind of promise made between Hume's two farmers. As with any promise, states may enter into such treaties from a variety of motives. Typically, however, they will be looking to alter the 
expectations regarding their future behaviour that the other party, or parties, to the treaty may have. Peace treaties will often be like this. At least part of the purpose of such treaties is to give the other side reason to believe that one's state will not restart hostilities whenever it is convenient to do so. If this cannot be done then it will be difficult to establish genuinely peaceful relations, rather than a mere temporary cessation of hostilities, between the two (or more) parties. ${ }^{65}$

Such treaties will often be conditional in nature although, as I note below, whether or not a treaty is conditional is up to the parties to the treaty to determine. If the treaty is conditional then this means that continued performance by one party will depend upon continued performance by the other party. If France and Spain, say, agree in a treaty to end hostilities (as they did at the Treaty of Vervins (1598)) and the treaty is conditional, then the resumption of hostile behaviour by Spain will see the resumption of hostile activity by France in return. Spain will have violated the treaty, in this case, and from the French perspective the very purpose of the treaty will have been undermined. Where the treaty in question includes many articles it may be possible to violate one (or more) article(s) of the treaty without, thereby, violating the treaty as a whole. Treaties, unlike the promise between Hume's two farmers, rarely concern the definite performance of

\footnotetext{
${ }^{65}$ Francis Bacon, in his discussion of treaties, tells the story of Iphicrates, the Athenian, who is negotiating a peace treaty with the defeated Spartans (Lacedaimonians). As Bacon tells it: "Finding that the Lacedaimonians were devising and propounding various sanctions and securities and bonds to hold the treaty fast [Iphicrates said] There is only one bond and security...that can hold between you and us:- you must prove that you have yielded so much into our hands that you cannot hurt us if you would" (Bacon 1825). Peace treaties, as Bacon suggests, are usually proposed and negotiated under conditions of mutual distrust and sometimes continued hostility although it may not be the case that one party is in a position to dictate such stringent terms as Iphicrates' Athenians.
} 
one simple task (Hardin 2007, 131). So, to return to the Treaty of Vervin, France may violate the agreement to revoke all sentences rendered against enemy subjects (Article 8). Spain may, as a result, react in kind. However, the failure to revoke all sentences passed against enemy subjects does not undermine the clauses of the treaty putting an end to the state of war between Spain and France (Article 2). Some treaty clauses are more central to the purpose of a treaty than others (see chapter 3). Violating these will typically see the treaty in question terminated. In the previous chapter I noted that a breach of such central terms is often termed a 'material breach'.

Multilateral contract treaties are interesting in the following respect. Take, again, the Treaty of Utrecht (1713) between Spain, Great Britain, and the Dutch Republic. I noted above that Spain could violate the treaty with the Dutch Republic and the Dutch Republic could respond in kind. Nevertheless both Spain and the Dutch Republic can continue to comply with the treaty with respect to Great Britain.

In this respect the Treaty of Vervin and the Treaty of Utrecht are like the promises between Hume's two farmers, Anita and Bob. Anita's promise to help Bob will, most likely, be conditional on Bob helping Anita first. ${ }^{66}$ After all, the point of the promise, for Anita, is to enlist Bob's help. She does not benefit by helping Bob but from Bob helping her. Confusion may arise, however, when the conditional nature of the promise or treaty is not made clear. This is because not all promises are conditional upon someone else keeping a promise in turn. For example, Anita could promise to help Bob with no

\footnotetext{
${ }^{66}$ Hume does not explicitly say this with respect to the two farmers. He does, however, consider cases where non-performance of a promise by a second party releases the first party from her promise in turn. Hume notes that this is the case "in all conditional contracts" $(\mathrm{T} 3.2 .9,550)$.
} 
expectation of Bob helping her in return (perhaps she needs no help). Such a promise would be unconditional in the sense that it does not rely upon Bob doing anything. These kinds of promises are sometimes called 'gratuitous promises'. ${ }^{67}$ When Anita makes a promise to help Bob and Bob makes a promise, in return, to help Anita, it may be that Anita is making an unconditional promise to Bob and Bob is making an unconditional promise to Anita. If Bob breaks his promise to Anita then, if Anita's promise is unconditional in this way, it would seem as though Anita still ought to keep her promise to Bob. The same may be true, at least in principle, of contract treaties too. I will say more about this below.

\section{Interdependent treaties}

The example I have just given of France violating the Treaty of Vervin if Spain first violates the treaty is an example of an interdependent treaty. The compliance of one party to the treaty is dependent upon the continued compliance of all the other parties to the treaty. In the case of the Treaty of Vervin there are only two parties to the treaty so French

\footnotetext{
${ }^{67}$ In principle contracts (at least in the common law tradition) cannot be gratuitous as they require 'consideration' by the other party. This means that both parties to the contract must undertake to do something of value in return. A 'contract' where you undertook to provide me with a yacht but where I offer nothing in return (I offer no consideration) would not be considered a valid contract. Complications arise when something of nominal value (say a peppercorn) is offered in exchange. See Fried 1981, 28 - 39 for a philosophical discussion of consideration. Treaties, like promises more generally, and unlike contracts, do not require consideration to be given. As we shall see below, parties to human rights treaties typically do not require anything in return from their treaty partners (except, of course, a commitment to the treaty).
} 
performance relies upon Spanish performance and Spanish performance relies upon French performance (at least insofar as treaty compliance is conditional on continued compliance by the other party). Bilateral conditional contract treaties are a sub-class of interdependent treaty. But not all contract treaties, whether bilateral or multilateral, are interdependent treaties. ${ }^{68}$

The Treaty of Utrecht, a multilateral treaty, is not an interdependent treaty. The continued compliance of the Dutch Republic does not depend upon the continued compliance of all the other parties to the treaty. The Dutch Republic can violate the treaty with Spain, because Spain has violated the treaty with the Dutch Republic, but continue to comply with the treaty with Great Britain. However, if the treaty were interdependent then the Dutch Republic's continued compliance with the treaty with respect to both Spain and Great Britain would depend upon both Spain and Great Britain continuing to comply with the treaty. Spain's violation of the treaty would see the treaty agreement with Great Britain also come to an end.

Perhaps the most clear-cut example of a multilateral interdependent treaty is a mutual disarmament treaty such as the Washington Naval Conference (WNC) (1921 - 1922). The WNC saw three parties, Great Britain, the USA, and Japan, agree to each reduce their naval power. In this case the failure of one party to comply with the treaty and disarm undermines the purpose of the treaty for all of the other parties. If Japan violates the WNC,

\footnotetext{
${ }^{68}$ This is not made clear in Fitzmaurice's account. For Fitzmaurice it appears that all contract treaties are conditional. The main difference between contract and interdependent treaties lies with the multilateral version of each. A multilateral contract treaty does not depend upon all the parties to the treaty continuing to comply whilst a multilateral interdependent treaty does so depend. I see no reason to think that all bilateral contract treaties are interdependent as Fitzmaurice suggests.
} 
by not disarming, then the USA and Great Britain cannot expect to realise the purpose of the treaty by continuing to disarm themselves solely with respect to one another. In this way the compliance of each party is dependent upon the continued compliance of every other party to the treaty.

\section{Understanding interdependency}

There is, in principle, little that is difficult to grasp about contract and interdependent treaties. Nevertheless, there are some features of conditional contract treaties (but not unconditional contract treaties) and interdependent treaties that distinguish them from unconditional promises (and treaties). I want to briefly point these out. It might be suggested that what I have called conditional contract treaties and interdependent treaties are, really, kinds of agreement and that agreements are, strictly speaking, different from promises. I shall reject this in what follows.

Let me say a little bit more about agreements and, in particular, three requirements that are supposed to jointly distinguish agreements from other forms of promising such as gratuitous promises. I shall make use of Margaret Gilbert's discussion of agreements (Gilbert 1993; and 1996, 313 - 338). If a treaty is an agreement then it seems to need to meet three requirements. Firstly, it must generate reasons to act. This requirement of something counting as an agreement is one that is common to promises in general. Secondly, these reasons must be generated simultaneously (which is not true of all promises). Finally, and most controversially, the reasons generated are interdependent, something which is thought not to be distinctive of promises. For simplicity I will mainly use the example of a bilateral conditional contract treaty by way of illustration in the following discussion. However what I say with regards to that treaty can be applied, 
mutatis mutandis, to multilateral interdependent treaties too. The conditional bilateral treaty I have in mind is a much simplified version of one between Hungary and Czechoslovakia (the 'Budapest Treaty' (1977)). Hungary undertook to build a dam at Nagymaros and Czechoslovakia undertook to build a dam at Gabčíkovo. Hungary attempted to terminate the project due to environmental and economic concerns in 1992. Czechoslovakia continued with a scaled down version of the project until 1993 when the country split and Slovakia continued with the project instead.

\section{The Three Requirements}

\section{3a. The Generation of Performance Reasons}

A treaty seems to generate, for each party to that treaty, some reason to perform some act (or, in some cases, to refrain from performing some act). Gilbert calls this reason the performance obligation (Gilbert 1993, 629 - 630). In previous chapters I offered the Humean account of how promises (and treaties) generate self-interested reasons for action. They may also trigger more general moral obligations not to undermine the social convention of promising and not to knowingly disappoint the expectations of the promisee but, depending upon the promise in question, they may not do so. So, I shall call the reason generated by means of a treaty a 'performance reason', rather than using the stronger term 'obligation'.69 The promisor has this performance reason because, in

\footnotetext{
${ }^{69}$ This does not make much difference to Gilbert's argument. In fact Gilbert notes that there is a sense in which agreements do not generate moral obligations. She does not give an account of what kind of obligations agreements generate as she sees this as not immediately relevant to her concerns (Gilbert 1993, 632 n. 13). I am not the first to talk of 'performance reasons' rather than 'performance obligations' (see Mintoff 2004, 49).
} 
making a promise, she grants to the promisee (and interested third parties) the right to withdraw trust in her in the event of a broken promise (Baier 1985, 178).

By means of the bilateral Budapest Treaty between Hungary and Czechoslovakia, then, Hungary gains a performance reason to build a dam at Nagymaros and Czechoslovakia gains a performance reason to build a dam at Gabčíkovo. Hungary and Czechoslovakia could instead have agreed to build a dam, the same dam, together, as a joint activity. Hungary would have a reason, in such a case, to build a dam with Czechoslovakia and vice versa. Now, in the case of the Budapest Treaty, Hungary, as I noted above, sought to unilaterally terminate the treaty. When they did this Czechoslovakia (later Slovakia) complained that their legitimate expectation of Hungarian performance of the terms of the treaty had been disappointed. In this case Czechoslovakia relied, to their detriment, upon Hungary to build a dam.

According to Treaty as Humean Promise the existence of a treaty between the two countries is good evidence that Hungary must bear a high degree of responsibility for any loss suffered by Czechoslovakia as a result of Hungary not building the dam. However, this does not mean that Hungary was not justified in seeking to terminate the treaty. Hungary might simply be required to give sufficient warning to Czechoslovakia that it intends to terminate the treaty so as to mitigate Czechoslovakian losses and even, perhaps, compensate Czechoslovakia for whatever losses are incurred as a result of its disappointed expectations. Performing these acts, and justifying termination of the treaty, may also succeed in mitigating other states' negative judgments of Hungary's reputation as a treaty violator. But the moral obligation to make good on Czechoslovakia's disappointed expectations, which are the result of the treaty, is not the same as a moral obligation to comply with the treaty just because there is a treaty. 
This feature of treaties is typical of both promises and agreements amongst individual persons as well as states. When I make a promise to mow your lawn, all things being equal, I gain a performance reason to mow your lawn. When we agree that I will supply parts for your car and that you will pay me for those parts I gain a performance reason to supply parts and you gain a performance reason to pay me. Insofar as it is also morally wrong to mislead me about paying me for supplying these parts you also have a moral obligation, triggered by the promise, not to avoid paying me (assuming you get the parts) or to make good on any harm you do me as a result of your failure. The claim that treaties are promises, then, means, at least, that both promises and treaties generate performance reasons, and sometimes also moral obligations, for those agents that make the promise or enter into the treaty.

\section{3b. The Simultaneity Requirement}

To understand the simultaneity requirement ${ }^{70}$ let us return to our two farmers, Anita and Bob. Anita and Bob now run a farm together. The farm's apples and corn need harvesting, both on Tuesday. Imagine that Anita says "someone needs to pick the apples and the corn needs harvesting". Bob responds "If you'll pick the apples then I will harvest the corn", to which Anita replies, “OK, then I will pick the apples". One feature of this exchange is that Bob gains a performance reason to harvest the corn and Anita gains a performance reason to pick the apples. But Bob, we can assume, has no desire to gain an unconditional performance reason to harvest the corn unless Anita gains a corresponding reason to pick the apples (Gilbert 1993, 630). But, unless they both speak at the same time or find some

\footnotetext{
${ }^{70}$ For Gilbert's discussion of the simultaneity requirement see Gilbert 1993, 630 and 1996, 315.
} 
other way of gaining a performance obligation simultaneously, one of them must speak first. But in speaking first s/he seems to thereby generate a performance reason whatever the other party decides. ${ }^{71}$

The way around this problem is to simply say that Bob does not gain his performance reason until Anita has replied (Mintoff 2008, 46 - 47). That is, although one party must speak first, Bob and Anita gain their respective performance reasons at the same time. We can certainly imagine that the Budapest Treaty is like this. Neither party desires to gain a reason to build the dam before the other party has taken on a corresponding reason to do so. Hungary does not want to build a dam on its own and neither does Czechoslovakia. Instead the treaty allows them to take on their respective performance reasons simultaneously. This is a useful feature of treaty making, especially in environments where parties to the treaty do not entirely trust other parties.

However, in multilateral treaties in particular, there can be some period of time between a state signalling commitment to a treaty and that treaty coming into force, as it awaits more signatures. So, for example, the Antarctic Treaty Environmental Protocol (1991) required twenty-six negotiating states to ratify it before it came into force. As a result entry into force was delayed by a full six years (Aust 2007, 174). This, potentially, gives states an opportunity to act in ways that would defeat the object and purpose of the treaty prior to its entry into force. So, if the treaty in question is premised upon a certain state

\footnotetext{
${ }^{71}$ So, for example, Anita might not agree to pick the apples. But Bob has already spoken. Should, on a whim, Anita decide to pick the apples Bob will suddenly have a self-interested reason to harvest the corn. But this is not what Bob wants when he offers the agreement to Anita. He does not want to create a reason to harvest the corn just in case Anita decides to pick the apples. He wants Anita to have a performance reason to pick the apples.
} 
of affairs obtaining then a state may decide to act in ways that would in some way undermine that state of affairs prior to the treaty coming into force. If the simultaneity requirement must be met before an agreement is made and the simultaneity requirement has not been met, then it looks as though the state in question cannot have broken any agreement (and has not, then, violated the treaty). However, I think we should say that the state in question has done something wrong.

For example, imagine that each of the parties to the Washington Naval Conference agreed to reduce their navies by one third. However, between the agreement being reached and entering into force, Great Britain decides to double the size of its navy. Once the WNC enters into force Great Britain will reduce its navy by one-third. But Great Britain's total naval power will still be much larger than the USA and Japan thought that it would be when they made the agreement with Great Britain. However, as the treaty has not, by hypothesis, entered into force, Great Britain has not violated the treaty. But it is has acted in a way that practically defeats the purpose of the treaty and the state of affairs in the world upon which negotiation of the treaty was based. In this case I think that we can clearly say that Great Britain has not acted in good faith. Great Britain has done something wrong, and morally wrong, even though that wrong is not the wrong of having violated the treaty. In this case I think that we should say that Great Britain has given assurances to its treaty partners and has, by knowingly undermining those assurances, wrongfully misled the other parties to the treaty. This is the same kind of wrong that I said that Hungary did to Czechoslovakia in unilaterally violating the Budapest Treaty. It is the wrong of disappointing legitimate expectations. This wrong can be done by violating an agreement or, as in this case, acting so as to undermine an agreement before it has even 
come into force. The wrong of knowingly misleading others, after all, does not only result from broken promises.

Now, some promises do not require another party to also take on a corresponding commitment at all. Gratuitous promises, where there is no expectation of reciprocation, are like this. When only one side gains an obligation by means of a promise then there is no question of performance reasons being gained simultaneously. Treaties can be gratuitous (although contracts cannot). What I shall call 'normative treaties', below, are typically like this. However the treaties I am interested in here involve all parties to the treaty gaining performance reasons as a result of the treaty. This is certainly true of the bilateral treaty between Hungary and Czechoslovakia. These performance reasons are, under normal circumstances, generated simultaneously.

\section{$\underline{\text { 3c. The Interdependency of Performance Reasons }}$}

So, we have seen that contract and interdependent treaties appear to generate performance reasons and that they generate those performance reasons simultaneously. The final feature of agreements, according to Gilbert, is that they create interdependent performance reasons (Gilbert 1993, 630 - 632; and 1996, 291). Two parts to this claim are of interest to us here.

Firstly, should one party to an agreement default on its performance reason(s), the other party (or parties) also ceases to have its performance reason(s) (Gilbert 1996, 317). The agreement simply comes to an end. If Bob defaults on his agreement to harvest the corn then, on this account, Anita ceases to have her performance reason to pick the apples. Likewise if Hungary does not build a dam then Czechoslovakia simply ceases to have a performance reason to build a dam. The party that first broke the agreement may have 
unresolved moral obligations. For example they may need to apologise to the other party or make good on their disappointed expectations. But any moral obligations for the disappointed party with respect to the agreement have ceased to exist with the agreement. They do not owe an explanation or apology to all those who rely upon the social convention of promising or an explanation or apology to the other party who has, in any case, already broken the agreement.

The second part that is of interest here is the claim that agents who make an agreement become, together, what Gilbert calls one "plural subject" and are hence jointly committed to some cooperative action (see Gilbert 1999, 147). Football teams and orchestras, for example, can take on commitments and the individuals who belong to those plural subjects can have obligations with regards to those commitments. Some treaty commitments are like this. The United Nations (UN) is a plural subject in this sense. All of the members of the UN are jointly committed to the cooperative activity appropriate to the UN. As a result each of them has a duty towards the UN to perform certain actions, whatever those actions happen to be. Each and every member of the UN, in other words, has certain obligations which arise as a result of being a part of the $\mathrm{UN}$, a plural subject which is committed to the performance of various activities such as maintaining peace in the world. The UN, furthermore, is something different from the members that constitute it and its commitments may not fully coincide with those of any individual member. Nevertheless it is important to note that each member of the UN has consented to becoming a member.

Some commentators point to the interdependency of the performance obligations generated by agreements to argue that agreements are really not kinds of promises at all. Some go further to claim that if something, say a contract, is in fact a kind of agreement, 
and if agreements are not promises, then contracts are not promises either (Smith 2004, 181). This objection would seem to be applicable to those treaties that are kinds of agreements. I do not think that this is correct for two reasons.

Firstly, like Hanoch Sheinman, I do not accept that reasons to keep the agreement automatically cease to exist when one party to an agreement violates the agreement (Sheinman 2011a, 365 - 395). ${ }^{72}$ They may do, of course, but not in any way that is at odds with our normal conception of promising.

Secondly, I shall suggest that what is important about calling treaties promises, whether Humean or not, is not that treaties are formally identical to promises amongst individual persons in every respect. They are not. Instead, what is important is the claim that treaties are kinds of promises insofar as the reason to comply with a treaty is justified on the same grounds as the reason to comply with promises more generally. Treaties are agreements, but they are particular kinds of agreements, ones that generate their performance reasons through some voluntary act. It is this feature that treaty-making has in common with promising and it is on the plausibility of this claim, rather than the claim that there are some differences between treaties (as agreements) and promises, that Treaty as Humean Promise (or, indeed, Treaty as Promise) will stand or fall.

\footnotetext{
${ }^{72}$ Sheinman presents a more sophisticated version of the argument than I do here.
} 


\section{Treaty as agreement}

Let us begin with the claim that the performance reasons that are generated by an agreement cease to exist when one party is settled on not performing its side of the bargain. The intuition here is that the agreement represents a joint undertaking, one that simply ceases to exist when one of the parties to the joint undertaking does not perform. If you and I agree to go for a walk in Wellington this afternoon, for example, but I later discover that you have instead boarded a plane for Istanbul and cannot possibly make the walk, I no longer seem to have a performance reason to go for a walk. My performance reason was a performance reason to walk with you. We had an agreement. If you break the agreement then it ceases to exist and so, too, do the relevant performance reasons. Although it is still true that you have broken the agreement, I cannot now do so.

This all seems plausible enough when two parties have agreed to do something like go for a walk together. A problem will arise for the claim that agreements are promises if no simple exchange of promises can adequately capture this kind of interdependency. We might think this because promises are normally thought to generate reasons to act that can only expire once either the terms of the promise have been kept (we have been for our walk) or the promisee releases the promisor from her promise (Gilbert 1993, 636). Gilbert argues that even conditional promises, of the form "I promise to (do $\mathrm{x}$ if you do y)", are like this although the condition that triggers performance may never, in fact, be met (Gilbert 1996, 325; see Mintoff 2008, 50).

It does, it is true, seem strange to say that because of our agreement to go for a walk together, which you have broken, I have any kind of residual reason (even a conditional one) to go for a walk because we agreed. It is stranger still to suggest that I have this 
reason until such time as you release me from it. Agreements are not like this, and so escape the problem of the strangeness of residual reasons because they cease to generate performance reasons for both parties. I just do not have a reason to 'go for a walk if you walk with me' that you need to release me from. Nor do I need to do my 'bit' of the walk. Instead the agreement and my performance reason just cease to exist once you have settled on not going for the walk. Likewise, Czechoslovakia appears to cease to have a reason to build a dam once Hungary is set on not keeping its side of the agreement and at least so long as Hungary remains set on not doing so.

However it is not obvious that default by one party of the terms of a treaty, even central and important terms, immediately ends the agreement in question. This is so even in the case of bilateral treaties where there is only one other party to the treaty. Whether the performance obligations generated by an agreement come to an end will depend, at least in part, on the content of the agreement. If Hungary and Czechoslovakia enter into an agreement, by means of a treaty, that:

Hungary is to build a dam and Czechoslovakia is to build a dam, then Hungary and Czechoslovakia have chosen to enter into an agreement whereby their commitments are not mutually conditional (Sheinman 2011a, 368). If Hungary fails to build a dam then Czechoslovakia would still have a reason, thanks to the treaty, to build a dam. Of course, Czechoslovakia could choose not to keep its side of the agreement and, it seems, Hungary would not be in a strong position to complain (ibid). But this is not the same thing as saying that Czechoslovakia ceases to have a reason to build a dam at all. After all they could have chosen to enter into an agreement where: 
Hungary is to (build a dam if Czechoslovakia builds a dam) and Czechoslovakia is to (build a dam if Hungary builds a dam),

This is a different commitment. There is, it seems, nothing about agreements that requires them to have this conditional structure. Further, to treat all agreements as conditional, when they are not, appears to fail to take seriously the agreement that the parties have, in fact, made (ibid, 367 - 368).

As I have noted in previous chapters, the agreements that we are interested in here involve the self-imposition of new performance reasons. Hungary may have some general performance reason to build a dam irrespective of any treaty commitment to do so. This can be distinguished from more general moral obligations not to knowingly mislead others or undermine useful social conventions and from the self-imposed, self-interested reason that Hungary has to comply with the treaty. Once Hungary has voluntarily entered into an agreement, or made a promise, it is that agreement, or promise, itself that generates Hungary's performance reasons and, possibly, triggers other moral obligations to act. An important feature of self-imposed reasons for action is that their imposition on an agent is justified, at least in part, because the agent (Hungary in this case) chose to enter into the agreement in question. Insofar as Hungary's performance reason is justified by some voluntary action that Hungary has taken (such as signing a treaty to that effect), and not, say, by the fact that Hungary has some other reason to build a dam, to take Hungary's commitment seriously is to hold Hungary to the actual content of its agreement, no more and no less. In short, to take Hungary's agreement seriously is to focus on the terms of the agreement itself, those that Hungary voluntarily generated by signing the treaty with Czechoslovakia. It is to not assume the content of that agreement on the grounds that all agreements, as agreements, must have identical features, in this 
case a condition that means that the performance reasons of both parties are automatically rescinded because of prior default by one of those parties (ibid, 369).

Of course, there is still the objection that the conditional contract treaty:

Hungary is to (build a dam if Czechoslovakia builds a dam) and Czechoslovakia is to (build a dam if Hungary builds a dam),

leaves Czechoslovakia with some strange, residual reason to build a dam even if Hungary does not. According to the Humean story, Hungary still has a right, in principle, to punish Czechoslovakia for noncompliance and it is this that generates a performance reason for Czechoslovakia. It is a performance reason that may never, in fact, be triggered because Hungary has already defected from its side of the bargain but it does sound strange to say that this conditional performance reason remains outstanding, as it were, until such time as Hungary releases Czechoslovakia from it. Unless Czechoslovakia has some other reason to build a dam in any case, it seems odd to suggest that it is in Czechoslovakia's interests to be prepared to build a dam (because their reputation depends upon it) unless Hungary releases them from the treaty.

It does, however, seem that the party that has not defaulted on the agreement might, as a result of the breach, have good grounds to justifiably renege on their own side of the agreement. Czechoslovakia, for example, might be saddled with bearing all of the costs and sharing the benefits with Hungary of building a dam on its own. And Czechoslovakia might, reasonably enough, be unwilling to do this. Depending upon the seriousness of the breach the grounds for non-performance may be very good indeed. But our normal concept of promising captures this kind of interdependency. We normally think that promises create performance obligations, all other things being equal. Where default by 
one party to a treaty leaves other parties vulnerable to exploitation or harm in some way were they to fulfil their performance obligations, there seem to be good grounds for claiming that, in fact, all else is not equal. In such a case it is fair to say that the treaty has, indeed, ceased to generate performance reasons.

So I think that it is an open question whether or not one party's defection from a treaty means that each other party to the treaty will also automatically cease to have performance reasons to comply with that treaty. There is not, I think, any very clear distinction to draw between agreements generally, on the one hand, and an exchange of promises, on the other, based upon the claim that the performance reasons of the former are interdependent in a way that the latter are not. In each case we would have to look firstly at what, exactly, the parties to the treaty agreed to. We should take agreements, and treaties, seriously. There may be grounds for the wronged party to cease to have any treaty generated performance reasons but this will not be because of some generic special feature of agreements.

Secondly, with Michael Pratt, we must distinguish between two things that could be meant by saying that treaties are promises (Pratt 2007, 531 - 532). Firstly, a treaty can be thought of as a kind of promise if the reasons that we give for saying that a state is bound by its treaty are the same as, or at least closely similar to, the reasons that we give for saying that a person - Anita, say, or Bob - is bound by her or his promise. In this way, the reasons to keep a treaty are grounded in the same kind of considerations as the reasons to keep a promise. This is the sense in which the view I have called Treaty as Humean Promise understands the claim that treaties are promises. According to this account both treaties and promises generate self-interested reasons for agents to act in virtue of the agent in question self-imposing just such a reason. Further general moral 
obligations can be subsequently triggered by this act (as noted in chapter 3 ). This is also true of the view I called Treaty as Promise whereby the agent directly self-imposes a moral obligation to comply with the treaty in question.

Alternatively, in saying that treaties are promises, one might mean that the act that is involved in entering into a treaty is identical with the act that is involved in making a promise. Now, it is in principle possible to think that the acts which comprise treaty making and promise making are identical without also thinking that the reasons to keep a treaty are grounded in the same kind of considerations as the reasons to keep a promise. So, one might think that the reason to keep a treaty is, primarily, a self-interested reason but that the reason to keep a promise is to build and strengthen morally significant relationships, even though one thinks that the act of treaty making and the act of promising are otherwise formally identical. On the other hand, one could think that the act of treaty making and the act of making a promise are not formally identical perhaps because the former is, strictly speaking, an agreement and because agreements are not identical with promises. Nevertheless, one can consistently think this and think that the reasons to keep a treaty, even if it is an agreement, and the reasons to keep a promise are both justified in the same kind of way (for example, by reference to the self-imposed character of the reason to keep a treaty and a promise). In this case, although promises and treaties differ in certain respects, they are simply different instances of the same kind of act (ibid, 532). This is the view outlined in the previous paragraph.

Treaty as Humean Promise, as we have seen, holds that treaties are promises insofar as the reasons that justify holding an agent to be bound by her promise are the same as those which justify holding a state bound to comply with its treaty. Treaties share with promises, and the kind of agreements looked at above, the characteristic of being self- 
imposed and, also, they generate self-interested reasons to keep the promise, or comply with the treaty, in question..$^{73}$ It is not necessary for treaties and promises to be identical in each and every respect for the claim that treaties are (Humean) promises to be true. We can combine this point with the argument offered above. Whether or not an agreement, or treaty, comes to an end if one or more parties violate the treaty depends upon the content of that treaty. And, for both contract and interdependent treaties, the content of the treaty ultimately depends upon the self-imposed terms of the treaty itself.

\section{B. Normative Treaties}

\section{Normative Treaties}

Normative treaties, or law-making treaties ${ }^{74}$, differ from both contract and interdependent treaties in several important respects. Contract treaties, as we have seen, involve a mutual exchange of benefits between the parties to the treaty and, as a result, various rights and obligations for each party encompassing specific conduct at the hands

\footnotetext{
${ }^{73}$ It is true that promises amongst individual persons may, in some instances at least, do things like strengthen morally important bonds between people. Even if this is true of individual persons and not of states, Treaty as Humean Promise claims that treaties are promises at least in the latter's capacity of being self-interested reason generating instruments.
}

\footnotetext{
${ }^{74}$ Terry Nardin disagrees with the use of the term 'law-making' with respect to treaties. This is because, according to Nardin, there is "no... distinct body that can properly be referred to as a 'legislature"' (Nardin $1983,124)$. Treaties, then, should not be seen as legislative instruments. My concern here is not with the law as such. It is enough, for my purposes, that normative treaties attempt to create rules for the society of states as a whole, whether or not those rules are, strictly speaking, legal rules.
} 
of, and towards, each other party to the treaty individually (Fitzmaurice 1958, Art. 18, para. 2). Multilateral interdependent treaties are a little more complicated but still require specific behaviour by parties to the treaty towards all other parties to the treaty. In addition, interdependent treaties are conditional whilst contract treaties may or may not be. With respect to interdependent treaties, the failure by one party to keep the treaty means that it is permissible for all other parties to the treaty to violate either the treaty as a whole or particular clauses. Normative treaties, on the other hand, are, in the words of the International Court of Justice (ICJ), "concluded for the purpose of establishing new rules for the law of nations" (ICJ Reports 1966, 266). That is, they are intended to create general rules of behaviour for states that go beyond the voluntary relations between states.

Paradigmatic examples of normative treaties include various human rights treaties. Earlier I mentioned the CTDT. Other examples include the Convention on the Prevention and Punishment of the Crime of Genocide (CPPCG) (1948) and the Universal Declaration of Human Rights (UNDHR) (1948). These treaties create various rights for individuals against the state and, also, obligations for states and individuals acting on behalf of the state. Some normative treaties aim to set international standards. So, for example the Minimal Age Convention (1973) aims to set certain minimal international employment standards. All of these treaties are multilateral but not all normative treaties are. Earlier I mentioned the Panama Canal Treaty which is a bilateral treaty. This treaty aims to create certain rights in third parties (in particular ships from states other than the USA and Panama). Finally, some treaties are constitutive of new international organizations. The treaties that founded the United Nations (UN) are like this. Once the organization has been established it can generate new reasons for the members that comprise the 
organization to act that are distinct from the promises that that constituted the organization in the first place. In this way the UN is what Margaret Gilbert calls a 'plural subject' (see Part A, section 3c, above).

Unlike contract treaties and interdependent treaties, violation of a normative treaty by one party does not give any grounds for the other parties to the treaty to violate the treaty either in whole or in part. So, should the USA violate the human rights of its own, or foreign, citizens, contrary to UNDHR, this does not give Great Britain the right to violate UNDHR in turn. One feature of normative treaties, then, is that they are unconditional in the sense that they do not depend upon the continuing compliance of other parties to the treaty in question. This is the sense in which such treaties can be said to create new rules, at least for the signatories to that treaty.

Insofar as they are intended to create general rules of conduct, and insofar as they are unconditional in the sense outlined above, normative treaties may be considered to have an important role in attempting to realise the ends of global justice, especially those that go beyond the interests and intentions of individual states. Indeed, this is how they appear in the work of some philosophers. For example Gillian Brock argues that, to realise global justice, all people must be "adequately positioned to enjoy the prospects for a decent life, such that they are enabled to meet their most basic needs [and] their basic liberties are protected" (Brock 2009, 322). In order to realise these ends Brock proposes a series of practical measures. These include, for example, agreements between states to formulate an "internationally harmonious tax regime" (ibid, 136), the creation of various new international organizations such as the "Vital Interests Protection Organization" (ibid,177), and an international agency to oversee the recruitment of healthcare workers from developing countries (ibid, 202). The purpose of these international agreements is 
to create new rules, or new organizations to enforce new rules, for the society of states as a whole. The actual agreement of states is merely the tool used to realise these ends. Realising these ends, insofar as they are requirements of justice, should be what states are aiming for irrespective of any agreement to do so.

The point of these agreements to create a harmonious tax regime and to found the Vital Interests Protection Organization and so on, is to create those general rules, and institutions to enforce those rules, that are required by the demands of global justice (according to Brock). It might be wondered, however, why treaties are to be used for this task. After all, it might be claimed, promises, and hence treaties, are usually thought only to bind those who make the promise. This is the sense in which they are self-imposed. But when we say that UNDHR embodies certain basic, fundamental human rights, we do not mean that it does so only for those states that have promised to respect those rights. The purpose of UNDHR is to protect the fundamental rights of individual persons wherever they happen to be and whether or not their state has promised not to abuse their human rights. There is some tension, then, between the purpose of a normative treaty (to create rules and standards for all states) and the treaty instrument. This is because, as I have suggested, the treaty instrument is usually and best thought of as a kind of promise and promises are only held to be binding on those who make the promise in question.

The purely pragmatic reason for using treaties to realise the various ends of global justice, and to create rules and regimes for all states more generally, is that there are few viable, or desirable, alternatives to doing so. The General Assembly of the UN, for example, lacks the power to impose general rules on states by process of a majority (or even 
supermajority) vote. ${ }^{75}$ The ICJ can only decide cases between states and its judgement is only binding if the state in question agrees that it is binding (Robertson 2006, 99). In 1961 Arnold McNair noted that the "treaty is the only and sadly overworked instrument with which international society is equipped for the purpose of carrying out its multifarious transactions" (McNair 1961, 739), a statement that is hardly less true today.

\section{Are normative treaties (Humean) promises?}

So, with respect to normative treaties, it might, on the one hand, be thought that they are promises and, as such, are only binding on those who have signed the treaty however much the substance of the treaty seeks to realise certain fundamental principles of justice. This was the view of the ICJ, which I mentioned earlier, which despite claiming that normative treaties are enacted in order to create rules for all states also claimed that normative treaties "bind only signatory States and...do not bind States which are not parties to them" (ICJ Reports 1966, 7). In the pronouncement of the ICJ we see, again, the tension, and possible confusion, between the intended purpose of normative treaties and the use of the treaty instrument, seen as analogous to a promise, to realise that purpose.

On the other hand we might accept that treaties are, as things stand, the best tool available to realise the ends of justice (and the other shared ends of the international community) but say that it is a mistake to think that normative treaties are like promises precisely because promises are binding only on those who actually make the promise in question. This was the view of Judge Alvarez who, in his dissenting opinion regarding the

\footnotetext{
${ }^{75}$ Even if it had this power, the General Assembly would not be representative with Andorra (population 85,000 ) having one vote and India (population 1.2 billion) having one vote.
} 
1951 Genocide Advisory Opinion, claimed that "these conventions [the CPPCG] signed by a great majority of States ought to be binding on the others, even though they have not expressly accepted them: such conventions establish...principles which must be observed by all States by reason of their interdependence” (ICJ Reports 1951, 52 - 53). Judge Alvarez' argument appears to appeal to some kind of majoritarian practice for determining such rules. ${ }^{76}$ But we do not need to accept that fixing such rules should be merely a matter of counting the number of states that happen to comply with them. The important point is that, however we ground them, these are rules that are supposed to be binding on states, and their governments, irrespective of any promise that they might make. ${ }^{77}$

What does Treaty as Humean Promise have to say about normative treaties? I do not think that we need to deny that normative treaties are promises even if we also want to hold, with Judge Alvarez, that they ought also to be binding on non-signatory states. There are often a number of different reasons to do that which is promised. Sometimes there will be a reason to do that which is promised irrespective of a promise having been made.

\footnotetext{
${ }^{76}$ This is a view with which Hume, who appeals to the "practice of the world" to fix international obligations, would likely concur (T 3.2.11, 569).

${ }^{77}$ International lawyers try to account for such principles by appeal to the agreement of states. States, however, may continue to engage in torture and so it might seem strange to say that they have 'agreed' not to torture people. However, these states will often attempt to hide it, supposedly because they know it is wrong. Torture, then, may be considered contrary to the opinio juris, what governments feel they are obliged to do. An opinion juris can become accepted by states as a rule from which no derogation is permitted and this, in international law, goes by the name of jus cogens. This gives rise to what is termed an erga omnes duty - a duty owed to the international community as a whole (Robertson 2006, 94 - 95).
} 
Insofar as states, and those who act on behalf of them, have a general moral obligation not to commit genocide, for example, then this is a reason that they have to act in certain ways whether or not they have also promised to do so. It need cause no particular problem to say that states can also promise not to commit genocide. Promising involves creating an additional reason to do that which is promised. Promises can thus be used to create reasons, where none existed previously, to do something utterly trivial. Alternatively they can be used to create some additional motivating reason to do something vitally important.

\section{Why use treaties? Two reasons.}

Even though there may be a general moral obligation (or some other reason) to act in a certain way irrespective of making a promise to do so, promising can still fulfil two important functions. Firstly, insofar as treaties create reasons to act that do not depend upon an evaluation of the act promised, they can be used to create some additional motivating reason to act in a certain way. ${ }^{78}$ Although a state may be committed to upholding human rights now, for example, it may find itself in circumstances in the future where it may not see those rights as particularly important. In earlier chapters I mentioned that USA was an early, and enthusiastic, adherent to the Geneva Conventions but that, following $9 / 11$ the US government sought to renege on certain provisions of the Geneva Conventions so as better to prosecute the so-called 'War on Terror'. States are not always motivated to do what they believe, or know, to be morally right. Just as individual

\footnotetext{
78 That is, treaties can be used to create reasons to act where the act in question is relatively trivial (like fixing the names of cheeses) or vitally important (like disarming nuclear stockpiles).
} 
persons can attempt to guard against future lapses in commitment by making a public commitment, and incurring costs in the event of failure, so, too, can the government of a state seek to bind its successors by entering into a treaty. So, this is the first way in which a normative treaty can still be thought to be a promise. It is a promise for those that enter into the treaty. This does not alter the fact that there may be other reasons not to, say, engage in torture. ${ }^{79}$

When the USA did attempt to renege on past treaty promises following 9/11 it did not simply come out and deny that the provisions of those treaties applied to it. Instead the USA attempted to circumvent those commitments. So, rather than saying that it simply had a right to torture enemy combatants, it sought to define 'torture' in such a way that it only included acts of interrogation that inflicted that level of pain which would be involved in organ failure or death $\left(0^{\prime}\right.$ Connell 2008,1$)$. Now, the point here is not that the USA still took its promises seriously (or was worried about the effect on its reputation for not doing so), although this may well be true. Instead I want to point to the importance of translating, or specifying, abstract principles, such as 'do not engage in torture', into common rules that are widely understood and shared. If other states, NGOs such as Amnesty International, and individual persons, are to properly hold states to account for

\footnotetext{
${ }^{79}$ Vattel makes a similar argument. He argues that treaties to abstain from harming others "are not necessary, and produce no new right, since every individual already possesses a perfect natural right to be exempt from harm." Nevertheless, he goes on, such treaties are useful amongst "barbarous nations" who think they can behave as they please and even among "nations less savage...who boast of a perfection much superior to the law of nature." Even where rulers "are little solicitous to merit the appellation of virtuous men, and... feel no scruple in silencing the reproaches of conscience", self-interest can step in to fill the motivational gap (Vattel 2008, bk. 2, chap. 12, sec. 171).
} 
their failures to adhere to the demands of justice then it useful for all to share a sense of what, exactly, these demands are and what counts as a failure to realise them.

Natural law theorists, starting with Aquinas, have called this specification the determinatio (Finnis 1986, 284 - 289; Waldron 2011, 55 - 56). The USA, for example, presumably agreed that torture was wrong and immoral but simply denied that what it was doing counted as torturing people. Treaties are often long, detailed, and technical instruments and this is partly because it is important to settle details, ensure that principles are administrable, and to give the parties to the treaty, and individuals and other groups that may have cause to call upon the treaty, reliable, predictable, and stable expectations of what they can and cannot expect from treaty signatories (Waldron 2011, 56). This last point ties in with an earlier claim I made in chapter 3. One of the important things, morally speaking, about promises is that they can give rise to expectations in others that it would be wrong to disappoint.

If we are concerned with realising the principles of global justice then it is important to also consider how they are to be enacted. So, to take an example discussed by Jeremy Waldron, Thomas Hobbes' $15^{\text {th }}$ law of nature is one that directly relates to international affairs. It says that "all men that mediate Peace, be allowed safe Conduct". ${ }^{0}$ But as Waldron points out, the operation of this basic, and abstract, principle in the world importantly depends upon how we fill in the details. Diplomats must typically do their work in a context that includes suspicion, misunderstandings, and sometimes hostility and for this reason there are a number of rules that deal with seemingly technical issues

\footnotetext{
${ }^{80}$ For Hobbes this law is ultimately grounded in prudential, rather than moral, considerations but the appropriate grounds of the rule this need not concern us here.
} 
such as the appropriate degrees of diplomatic rank, diplomatic immunity, the size of diplomatic missions, and so on (ibid). And much of this is contained in the form of a treaty, the 1961 Vienna Convention on Diplomatic Relations which contains 53 Articles and various additional sub-clauses.

Of course, such detailed specification may not always be achieved by means of the treaty document itself. Especially with large, multilateral treaties it can be difficult to settle on specific rules that all the various parties to the treaty can agree upon. Some, or perhaps many, of the negotiating states will be unhappy with at least some parts of the resulting treaty. The greater the detail the more scope there is for such dissatisfaction to arise and threaten the treaty. Nevertheless, the treaty process is not only about creating a reason to do that which is promised. States can also use the treaty process as an opportunity to clarify the meaning or scope of the treaty's provisions. So, for example, the UK agreed to the Rights of the Child Convention (1989). In doing so, however, it sought to clarify which people it understood the term 'parent' to include. Such activity is a useful way of specifying a potentially difficult term in practice (Aust 2007, 127).

So, I do not think that it is misleading to call so-called normative treaties promises. They are promises for the signatories to the treaty in question insofar as they involve the creation of an additional reason (self-interested) to do that which is promised. Insofar as they do this then they can also trigger other, general moral reasons to do that which is promised. I have suggested that they can generate expectations in others, states and individuals alike, which it would be wrong to disappoint. But, of course, all this does not alter the fact that often there is some very good reason to do whatever it is that the treaty is about in any case. There are good moral (and non-moral) reasons not to engage in torture, to allow those that mediate peace safe conduct, and so on. That there is a treaty 
regarding these things is not a reason to think that they only apply to those states that have actually promised to do them. For those states that do make the promise the treaty can serve an additional purpose. As we have seen it can help to specify the content and scope of general moral principles, what the natural law theorists term the determinatio.

Given the current lack of effective legislative institutions at an international level it is the practice of promising, in the form of treaties, that must currently fill the role of taking us further towards the end of securing general rules binding upon all states. The treaty instrument can, I think, serve this task. This is because treaties, like promises, are versatile instruments. However it is important to remember that moral obligations, and general reasons to act, do not begin and end with promises. The USA, for example, ought not to engage in torture whatever promises it has also made not to do so.

\section{Settling for second-best?}

I do not think that it is inappropriate to consider normative treaties as genuine promises. Indeed I have suggested that making a promise to, say, set up a harmonious international tax regime or prohibit the use of torture, can be useful as an additional source of motivation and as a means of translating abstract principles into determinate rules. However, the use of treaties to create rules for members of the international community is, in many ways, a second best option for want, as I noted above, of currently viable alternatives.

The purpose of many normative treaties is to place limits on the actions of states and those, in particular governments, who claim to act on behalf of the state. This is especially true of treaties that aim to protect human rights. Rules that require states to uphold the human rights of their citizens place limits on the exercise of state sovereignty. As we have 
seen, however, the use of treaties to achieve these ends suggests that state consent remains central to realising these rules. Now, I have noted that we need not accept that state consent creates a moral obligation not to abuse human rights. Still, the use of the treaty instrument to realise the goals of global justice means that slow progress will be made. Governments, who are generally assumed to act on behalf of the state, are generally wary of consenting to the imposition of external limits over their behaviour, especially with regard to their behaviour with respect to their own population. In this respect using treaties to make general rules supposedly binding upon all states may seem to concede too much to states, the very entities that those rules seek to control. This is especially true if, as I suggested above, treaties are used to determine the scope and specific content of abstract moral rules. Like the USA with respect to the definition of torture, the use of the treaty instrument appears to favour the interests of states, and those who control them, rather than the interests of those who may, for example, find themselves subject to torture.

If we are serious about realising the ends of global justice, even of a basic kind such as ensuring that fundamental human rights are respected, we may do better to rely less upon treaties and more upon improving and strengthening the institutions of international governance. Leaving the matter to treaties, as promises, gives the impression that upholding human rights, not committing genocide, and so on are in some way optional and this, I think, is a mistake. There are various ways in which the institutions of global governance could be strengthened. For example, if the goal is to uphold human rights it would be appropriate to allow individuals to bring cases against their state to the ICC. Other proposals, some more ambitious than others, have been made and deserve serious consideration. I have already noted Gillian Brock's discussion of the 
creation of various international organizations equipped to uphold the various ends of global justice. However, the irony is that if these kinds of international organizations, and general rules binding on all states, are to be realised beginning from where we find ourselves here and now, they will almost certainly be pursued by means of the very instrument they will be intended to replace; the treaty. In this sense it is important to keep in mind the distinction between the different kinds of reason that an agent has to keep a promise. In this way we can avoid thinking that states only have moral obligations if they consent to those obligations.

\section{Conclusion}

In this chapter I have given a typology of three different kinds of treaty, based upon Fitzmaurice's schema. I have distinguished between contract treaties, interdependent treaties, and normative treaties. I noted that there can be bilateral or multilateral versions of each of these kinds of treaty. I also argued that each of these kinds of treaty can be best thought of as Humean promises, despite some reasons to think otherwise.

The reasons to think otherwise took two forms, depending upon whether the treaty in question is an interdependent treaty or a normative treaty. It might be argued that interdependent treaties are not promises because they are agreements and agreements are not promises. I reject this argument. Although interdependent treaties are agreements, in the sense outlined above, I do not think that this precludes them from also being promises. This is because, ultimately, what determines whether a treaty is interdependent or not is not some generic feature of agreements not to be found in promises but, rather, what the parties to the treaty in question consented to. And this, ultimately, is perfectly consistent with Treaty as (Humean) Promise. 
On the other hand, normative treaties may be considered as not being promises because they are intended to create general rules, and international organizations to enforce those rules, for all states, even those that do not consent to the treaty in question. But promises are typically thought only to bind those that make the promise. This is the sense in which they are self-imposed and this is the sense in which I suggested that interdependent treaties are, ultimately, promises. However, I suggested that there is no particular reason why we should not understand normative treaties as promises. However, in order to do this properly we must remember that there are different kinds of reason that an agent may possess to do whatever it is that she has promised to do. Some of these reasons may have nothing to do with the promise itself.

Treaty as Humean Promise, I suggested, helps us to see this as it distinguishes between the self-imposed, self-interested reasons to keep a promise and other reasons, including moral reasons, to do that which is promised. Although the treaty instrument may not be the most appropriate mechanism for creating general rules for the community of states it is the mechanism that we currently have available to do this. Indeed, insofar as we wish to improve and strengthen the institutions of international governance, this will most likely be done by means of the treaty, at least initially. It is important, then, to remember that although normative treaties are promises, for the signatories to that treaty, that this is not the whole story. There are, usually, other reasons for states (including nonsignatories) to do what the treaty would require them to do. Although treaties are promises, promises do not comprise the whole of morality. 



\section{Chapter 5: Who should comply with a treaty? Treatise 3.2.11}

Chapters 5 and 6 look at Hume's own application of the view I have labelled 'Treaty as Humean Promise'. This view is largely taken from a short chapter of the Treatise called 'Of the Laws of Nations' (T 3.2.11, 567 - 569). In this chapter I briefly address who has responsibility, and of what kind, for complying with a treaty. As we shall see Hume is not clear. I suggest that in some cases moral responsibility, or approbation and disapprobation, should fall properly on the decision makers in the state but that what David Miller calls 'outcome responsibility' should generally fall on the state itself and, by extension, the citizens of that state. In some instances, however, it is appropriate to hold the citizens of a state morally responsible for treaty compliance and violation. On the other hand in some instances it will not be desirable even to attribute outcome responsibility to the citizens of the state. This will normally be where the state in question is a so-called 'failed state'.

\section{Introduction}

In previous chapters I noted that individual persons and states often face similar difficulties when attempting to cooperate. One of these difficulties is that of making credible commitments to one another. Promising appears to offer a means of overcoming this difficulty available to both individual persons and states. I noted that it is a strange way of overcoming these difficulties as it appears to involve creating a reason to do that which is promised simply by communicating an intention to create just such a reason. This has struck many, including Hume, as mysterious and problematic. I think that we can 
give a plausible account of how this problem - and others - can be overcome. This is by means of what I called 'the Humean theory of promising'. Extended to treaties this view I called Treaty as Humean Promise. It is a Humean view of promises (and by extension treaties) because it is based upon Hume's account of promising.

Now, Hume himself explicitly extends his theory of promising (and justice more generally) to international affairs. He does this in the Treatise (T 3.2.11, 567 - 569) and also in the Second Enquiry (EPM 4, 206). Hume argues that the requirement to keep promises applies as much to states as it does to individual persons (T 3.2.11, 567 - 568). Unsurprisingly Hume endorses Treaty as Humean Promise. But in the process of applying his theory of promising to the international realm Hume makes some interesting claims. At least one of these claims is surprising. In fact Hume thinks that "certain philosophers" will find it "shocking" (ibid, 568). I return to this in the next chapter. In this chapter I want to begin looking at Hume's own application of his theory of promising to international affairs in order to see just how Humean Treaty as Humean Promise should be. In what follows I address Hume's use of eight different terms, in two and half pages, to discuss who, exactly, has responsibility for complying with a treaty and making good for any violation of the treaty.

\section{A profusion of terms}

In just two and half pages comprising Hume's discussion 'Of the laws of nations' in the Treatise Hume employs eight different terms to refer to the agents which make (and keep and break) treaties in international affairs. Hume sometimes refers to different kinds of associations of people. So he talks of "different societies", "neighbouring states", the "body politic", "different nations", "independent kingdoms", and "republics" (T 3.2.11, 567 - 
569). Hume seems to treat these as synonymous terms. He has in mind certain kinds of organized political associations which all possess what Hume calls 'civil government' (ibid, 567). Hume also discusses the moral duties of "princes" and of "ministers" (ibid, 567 - 569) which are roles that individual persons may play within a state and which may represent the state in its interactions with other states.

Hume, I think, is using all of these terms interchangeably. ${ }^{81}$ He notes that we are told that a "body politic" should be considered "as one person". He thinks that is an appropriate comparison in some respects but that, in other, unspecified, ways "they are very different" (ibid, 567). Hume is adopting the common idea that states, as such, have responsibilities (for example the responsibility to comply with a treaty) and that these responsibilities are not properly reducible to the responsibilities of the individuals acting on behalf of the state. So a particular government, say the British Conservative government of 1992 - 1997, acting on behalf of the state may incur a large national debt. But members of this government are not held individually answerable for the debt which would, in any case, be beyond their means to repay. Instead the UK, the state, is held to be accountable for that debt. Managing the debt is the concern of the next government (Runciman 2003, 43 - 44). Likewise a treaty commitment to act to prevent genocide is signed by specific individuals. But the signatories themselves do not bear the responsibility of acting to prevent genocide, the state that they represent does (although, as leaders, they have a responsibility to play their part in ensuring that the treaty is complied with).

${ }^{81}$ Hume talks, for example, of "justice among princes and republics" (T 3.2.11, 569). 


\section{Very different in other respects}

Some difficulty may be thought to arise, however, in identifying a sense in which something called 'the state' can actually take such a responsibility. Ultimately, it might be argued, it is not the state that is in control of what it does because, when we look more closely, control lies with the individuals who represent the state. This is because whatever is done by a state must be done by some representative of that state. Where that is the case, it might be held, responsibility properly lies with those individuals (see List and Pettit 2011, 160). We might hold the state accountable, as we do for the national debt for lack of any other agent able to repay that debt. But to hold the state responsible, to apportion blame or praise for example, would be to accept that running up the debt was an action of the state. But it is not, at least according to the view explored here. It is the action of those who represent the state (and, perhaps, those who voted for them). ${ }^{82}$

What does this have to do with treaties? Well, one feature that makes treaties like promises, Humean or otherwise, is that they involve the self-imposition of reasons to act. But according to the argument above a state, as such, lacks control over the decision whether or not to sign a treaty. The control lies with the representatives of the state who

\footnotetext{
${ }^{82}$ For List and Pettit the group agent (say, the USA) is fit to be held responsible for ensuring that some of its members perform in the manner required (say, by doing what is required to comply with a treaty) (163). On this view the group is not responsible for complying with a treaty as such (individuals are) but with designing the group's decision procedures such that the treaty is complied with.
} 
sign (and ratify) the treaty. ${ }^{83}$ This means that those signing the treaty may, as Treaty as Humean Promise claims, have incurred self-imposed reasons to comply with the treaty. Future representatives of the state may also have a (self-interested) reason to comply with the treaty. Whatever this latter reason is, however, it is not self-imposed. It has been imposed by previous representatives.

Such a view has struck some people as highly plausible. This way of understanding treaties was, in fact, common in medieval practice and it had some significant practical consequences. We are used, today, to drawing a distinction between the office, that of a prince for example, and the person who fills that office, the particular man who is the prince. But this distinction has not always been a common one. In medieval practice it was common, for example, for a treaty signed by a prince to require reaffirmation by his successor if it was to remain in force (Brown, Nardin, and Renegger 2002, 251).

As late as the $17^{\text {th }}$ century James VI and I argued that, as King, he was not bound by the promises of his predecessors because he had not made the promise. If he kept the promise it was for other reasons than it being a promise, such as his regal 'goodwill' (MunizFraticelli 2009, 397 - 398). This way of thinking about treaties (and laws and constitutions more generally) took on new life with the rise of modern democracy. In the $18^{\text {th }}$ century Thomas Jefferson argued that because political legitimacy properly rests upon the consent of the governed, future generations could not be properly bound by the actions of their predecessors to which they had never consented. Future generations could choose to reaffirm those commitments, and should get the chance, thought

\footnotetext{
${ }^{83}$ This does not mean that we must always look to find just one individual who is responsible. A politician can act on instructions from a group and, in a democracy at least, this will often be the case. Control here lies with the various members of the group giving the instructions rather than the state itself.
} 
Jefferson, periodically, but if they did not do so then they were not bound by them. They had not self-imposed any reason to comply with that treaty or, indeed, any law passed before they could give consent although they could choose to do so if they wished (ibid, 380 - 383). Jefferson's basic idea, if not his specific proposal for an actual vote roughly every generation, still has its supporters today (Otsuka 2003, 139 - 141).

All this, in itself, does not mean that treaties are not Humean promises for those that make them. King James can still give himself a reason to act in a certain way by signing a treaty and so, on Jefferson's proposal, can a particular generation of a democratic people. But whilst for the successors of the treaty makers there may be good reasons to continue to comply with the treaty these reasons are not self-imposed. Many treaties are intended to last significant periods of time, perhaps generations. Those that do, on this view, may start out as Humean promises but, at some point, cease to be Humean promises properly speaking because the reasons they impose are not self-imposed.

Although accepting such an argument does not entirely undermine Treaty as Humean Promise it does limit its scope. Talk of the reasons that a state has to comply with a treaty is really a short-hand way of referring to the reasons that the people who are members of that state have to comply. Some of these people will have reasons to act because they have made a kind of promise to do so but this will not be true of everyone. In particular it may not be true at all of members of future generations. Let us call this view 'limited scope Treaty as Humean Promise'.

\section{Princes or states?}

Limited scope Treaty as Humean Promise is, I think, a useful way of thinking about some treaties but is actually quite misleading in other instances. In some cases it is appropriate 
to hold that a particular figure or group, such as a government or junta, within a state has made a promise, by signing a treaty, that cannot reasonably be considered a promise made by (or even on behalf of) the state itself or the general population of that state. Some states, for example, possess unstable governments that change rapidly. The formal institutions of such a state, for example the decision making procedures that it has, will often be closely bound up with the particular individual that fills that role at any one time, so much so that we can reasonably doubt that the state does exist beyond those individuals (Erskine 2003, 29). Oliver Cromwell's short lived Protectorate of England (1653 - 1659) was like this as may be contemporary regimes that rely heavily upon charismatic leaders and personality cults. In some cases we do hold individuals to be liable (legally and morally) for actions supposedly taken in the name of the state. For example, Augusto Pinochet was held by many to be personally liable for war crimes committed in the name of the Chilean state. Likewise we may, in certain instances, justifiably hold particular individuals and governments responsible for promises made in the name of the state.

But those instances where we hold individual persons liable for actions taken in the name of the state are typically also instances where we feel that something has gone wrong with the state in question (ibid, 28 - 34). In Hume's terms we might say that they lack proper 'civil government'. In some of these states the exercise of power is personalized, in the form of, say, a dictator, warlord, or a junta. In others there may just be no meaningful institutions in place to deliberate, as a group, on shared courses of action. We sometimes even use terms like 'failed states' to describe these states. But in other states, for example most modern democracies, these features do not exist. For example, although some people hold George W Bush or Donald Rumsfeld liable for war crimes, just as 
Pinochet was, the case is not as clear cut and this is partly because the exercise of political authority in the USA is not as personalized as it was in Pinochet's Chile. Instead the exercise of political authority is abstracted away from the individuals who wield power and hold office at any particular time. It is far more difficult to distinguish the personal acts of a Bush or a Rumsfeld from the acts of the state they represent.

The USA, as a state, may be thought of as an agent in its own right in a way that those states closely identified with a particular leadership cannot. The USA is not simply the conjunction of the identities of the current constituent members of the state. It survives changes in the composition of its membership. Most individual members of the USA understand themselves as belonging to a group that possesses an identity over time, including a shared past and future. The USA also possesses sophisticated decisionmaking procedures. In the form of various agencies, committees, Congress, and a Presidency, the USA is able to access and process a massive amount of information, beyond the scope of any one individual. And, despite this wide array of agencies, committees, Congress, and Presidency, the USA possesses at least some degree of decision making unity (French 1984, 13 - 16; Erskine 2003, 21 - 24). ${ }^{84}$

\footnotetext{
${ }^{84}$ See Peter A French, Collective and Corporate Responsibility (1984), especially chapter 1, for a good discussion of corporate identity, on which I have drawn above. For French the crucial distinction is between what he calls an "aggregate collectivity" which is "merely a collection of people"(5) and a "conglomerate collectivity" where the identity of the collective agent is not exhausted by the conjunction of the individual persons who currently comprise it and where it possess internal, unified decision making procedures $(13-16)$. Conglomerate collectives can include things like Oxfam, Microsoft, West Bromwich Albion Football Club, and the USA. French is mainly concerned with corporate (i.e., business) agents. One difference between, say, Microsoft and the USA is that individual shareholders in Microsoft typically decide whether or not to be a part of Microsoft whilst typically (but not always) individual
} 
There is an important sense, then, in which we can say that the USA and Canada made a promise in 1961 when they signed the Columbia River Treaty. That Dwight Eisenhower and John Diefenbaker have both long left office (indeed have both died) and their respective Senate and Parliaments are both comprised of different people, is not important so far as the promise goes. Trying to understand the promise, and the responsibility to keep that promise, in terms of the actual individuals who made the promise is helpful in some instances but, in other instances, such as the Columbia River Treaty it is misleading to do so. It is misleading because it fails to capture the important kind of collective decision making procedures, and fairly stable identity over time ${ }^{85}$, possessed by both the USA and Canada. It is possible to hold some states responsible for the decisions of particular political leaders, princes or otherwise. To be sure, however, it remains an open question whether any particular state should, in fact, be held responsible in this way. The extent to which is appropriate to assign responsibility to a state, as opposed to certain individuals within the state, will, no doubt, be a matter of degree. As we see below it is also often the case that even within open, democratic, and stable political communities the degree to which it is appropriate to attribute moral responsibility for particular acts undertaken in the name of that community will vary.

Americans do not make such a decision with respect to the USA. For an application of French's position to states see Erskine $(2003,21-24)$.

85 This sense of identity may be grounded upon prudential considerations, such as a desire to be taken seriously as a group, as I discuss in chapter 3. 


\section{Moral, outcome responsibility and Treaty as Humean Promise}

All the above is not to say that those acting in the name of a state like the USA should bear no moral responsibility for the actions they choose to undertake. Even in instances where the group as a whole decides upon some plan, and an individual merely implements that plan, that individual could have refused to play that role. If the decision is one made by the group, say through the deliberative institutions of the state, it is, however, likely that someone would play that role even if it is not that specific individual who, in fact, did so (List and Pettit 2011, 161 - 163).

In other cases leaders and decision makers will act in ways, on a given issue, that do not reflect the will of the population of the state. This can, and does, happen in democratic systems just as in other forms of government. ${ }^{86}$ In most actual cases the degree of control

\footnotetext{
${ }^{86}$ Hume's own judgment, famously, is that, in politics, "every man ought to be supposed a knave, and to have no other end, in all his actions, than private interest" (Hume 1987g, 42). The problem, with respect to treaties, is this. The knave with political power does not necessarily see her reputation tarnished to a significant degree by any single act of treaty violation. The reputational costs incurred are, instead, externalized onto all of the citizens of the state (present and future). In a sense, then, the knavish politician who violates or even enters into a treaty for personal (or political) gain, or on behalf of special interest groups, can reap the (concentrated) benefits of doing so whilst distributing the (reputational) costs across all the citizens of the state. Reputational capital is a public good and the knavish politician free-rides on it. We should keep this in mind, Hume thinks, when we are "contriving any system of government and fixing the several checks and controuls of the constitution" (ibid). In large groups, Hume notes, the reputation based "check is, in a great measure, removed" (ibid, 43).
}

Hume's view is that we cannot hope to remove such knavishness but we can control it by inducing knaves to act so as to further the public good. Hume thinks that a mixed government of checks and balances can 
exercised over the actions of leaders is limited. The population of the USA had greater control over the actions George W Bush who was at least elected than it did over the actions of, say, Henry Kissinger (or Donald Rumsfeld) who was appointed by a particular President.

The extent to which the state as a whole, or the population of that state, is an appropriate subject of moral praise or blame (or in Hume's terms, approbation or disapprobation)

work to achieve this. In particular, the knavishness of one (individual or institution) can be used to counter the knavishness of another. Competing knaves within particular institutions (say, within parliament) will check one another. And different institutions (say, parliament and government) will check one another (ibid, 45). Although we cannot hope to completely align the interests of citizens and rulers we can minimize the degree of disparity between those interests.

One interesting corollary of all this is that whilst Hume is concerned to persuade the sensible knave (an individual) that he should not, in fact, be a knave (EPM 9.2, 282 - 284), in politics, it seems, we need to encourage such knavishness because theories of politics that suppose a "great reformation in the manners of mankind, are plainly imaginary" (Hume 1987f, 514).

Hume's own preference seems to be for the British (or, rather, English) model (a constitutional monarchy where the monarch has some effective powers) which has developed, and evolved, over hundreds of years. Hume tells this story in his voluminous History. (For further discussion of how Hume's History informs his political theory see Sabl (2012)). In this way Hume avoids the problem of having one person (who may himself be a knave) write the constitution. Britain has had this, says, Hume, in the form of Cromwell and that, he notes, did not turn out well at all (Hume 1987h, 52). Although we do not need to accept Hume's apparent conservatism on this matter, it is important to note that Hume was well aware of the problems involved in naively assuming that the government, or some individual, shares the interests of the state, and its citizens, as a whole. 
will vary according to particular circumstances. We may hold the population of a state to be partly blameworthy if, say, they elected a leader who has chosen such a course of action or, alternatively, if they were negligent in holding that leader properly to account. Typically, however, the consequences of actions undertaken in the name of the state are attributed to the state insofar as the burdens and benefits of the actions taken in their name fall upon the state as a whole. We can attribute responsibility in this manner even in cases where we do not also attribute moral responsibility to the state. This is the sense in which the public debt, run up by a particular government, is thought to be the responsibility of the state rather than any specifiable set of individuals even though the government itself may properly be considered morally responsible, that is, the proper subject of moral blame, for that debt. David Miller has called this kind of non-moral responsibility 'outcome responsibility' to distinguish it from full moral responsibility (Miller 2004, 244 - 246). This is an important distinction because, in some instances, we do hive off moral responsibility, as it were, to individual decision makers but nevertheless hold the state, as such, outcome responsible.

Treaty as Humean Promise, I think, does a good job at capturing this distinction between moral responsibility and outcome responsibility in the case of treaties. Remember, the moral reasons that we have to keep promises (and treaties) are, on the Humean account, general moral reasons that we have not to undermine or free-ride on useful practices and not to knowingly mislead others. These reasons are not self-imposed. The promise, or treaty, acts so as to fix the level of moral responsibility for any harm resulting from the violation of these general moral obligations. Typically promises set the bar of responsibility at a high level. We set demanding requirements on the acceptable excuses needed to avoid moral blame for breaking a promise. This goes for treaties too. But, in 
some instances, say where the leadership of the state makes a widely unpopular decision to violate a treaty, or where the violation occurred before the current population of the state were born, we may be less willing to hold the state and its current population morally blameworthy for those actions and with good reason. The state, as such, or the general population of the state, cannot be said to be in control of the actions taken in its name.

According to Treaty as Humean Promise, however, the self-imposed reason to comply with the treaty does not presuppose the existence of moral reasons to comply although, to be sure, moral praise and blame often accompany treaty compliance and violation. The self-imposed reason is a self-interested motivating reason to keep the promise. But the self-interested reason does presuppose outcome responsibility for the state. The consequences of actions taken in the name of the state, say a loss of reputational capital, are attributed to the state as such. This is what happens when we hold a state (outcome) responsible for the debts run up by particular governments acting in the name of the state. Treaty as Humean Promise does allow us to talk about moral responsibility for treaty compliance. However it captures the sense in which a treaty is a promise even in cases where we feel that moral responsibility, praise and blame, is misplaced or inappropriate at least for certain agents. In those cases we can talk of the outcome responsibility to comply with a treaty. The burden of treaty violation typically falls upon the state as such even where moral blame falls properly upon the leadership of that state. 87

\footnotetext{
${ }^{87}$ In some instances - I mentioned Pinochet's Chile or Cromwell's England - we may even be wary of attributing even outcome responsibility to the state. In those cases, insofar as we are justified in holding a
} 
We might say that it is in the interests of the state that it does not default on its debt. I have suggested that this is an acceptable way of talking about the state, as such, where it possesses an identity that it is more than the sum of the identities of its members and where it is capable of purposive action that is not easily attributable to the actions of any specific individuals acting alone. Some people may be uncomfortable with this way of talking about the state. But if we do talk about the state in this way we do not also have to think of the state as a kind of corporate person with interests that we can understand without reference to the interests of individuals that populate that state (Teson 1998, 41). It is in the self-interest of members of the state that the state does not default on its debts once a government leaves office. It is in their interests as members of a particular kind of political association. Although it is tempting in the short-term to default on a debt doing so acts as a deterrent to future investors. Many important projects cannot reasonably be completed within the lifetime of a single generation or the periods of office particular leaders. The USA and Canada entered into the Columbia River Treaty to secure against future flooding and to work together to generate power. These shared plans were made, in part at least, for future benefits and, in order to realise those benefits, Canada and the USA needed to take on long-term commitments. It is in the interests of members of states to accept outcome responsibility for treaties both to reap the benefits of past agreements and also, importantly, to be able to make commitments, and hence increase certainty, for the future.

particular regime outcome responsible for its actions, the view that I called 'limited scope Treaty as Humean Promise' seems to me the correct approach. 


\section{Conclusion}

It is not clear what exactly Hume has in mind when he talks, variously, of the obligations of kingdoms, republics, princes, ministers, and nations. He is certainly aware of the difference between an office and the person who fills that office. And he does explicitly compare and contrast certain groups (in this instance, "nations") with individual persons. But it is less clear whether he thinks such talk of the reasons and obligations of states is, really, just a compendious way of talking about the reasons and obligations of those people who are members of that state (as Jonathan Harrison thinks $(1980,230)$ ).

I think that it is possible, and useful, to talk about certain groups as able to self-impose reasons for action without thereby also referring to the particular individuals who acted on behalf of the group. We can also hold the group itself morally responsible, at least to some extent, and outcome responsible for keeping the promise. In this sense Hume is correct to say that states "resemble individuals". Still, it is an open question in any particular instance whether we are justified in attributing moral responsibility to the group or to those who claim to speak for the group. In some extreme cases, where 'the state' is so closely identified with a particular individual or group, as in Cromwell's England, it may be proper to attribute both moral and outcome responsibility fully to that individual or group rather than to the state itself. In any case properly allocating moral responsibility and, to a lesser extent, outcome responsibility is far less straight forward in international affairs than it is amongst individual persons. This is one difference between the treaty promises of states and the promises made by individual persons. 



\section{Chapter 6: The Shocking Maxim. Treatise 3.2.11 - 3.2.12}

This chapter continues my discussion of Hume's application of 'Treaty as Humean Promise'. It investigates Hume's main argument in T 3.2.11 (and which continues into 3.2.12). Hume aims to defend what he admits will be, to some, the shocking maxim that international morality properly has less force than morality for individual human beings (although it has the same extent). This section of the Treatise has not been widely discussed by commentators. Of the few who do discuss it few endorse Hume's position. In this chapter I attempt to provide what I consider to be the most plausible reading of Hume's argument. In so doing I also defend 'Treaty as Humean Promise' more generally from criticisms made against it by Marshall Cohen. I conclude that although Hume may be wrong to endorse the shocking maxim, whether he is or not turns on empirical questions rather than some deeper flaw in his theory. I finish by pointing to some relevant empirical considerations.

\section{Introduction}

Most of Treatise 3.2.11 is taken up with Hume's rather cryptic discussion of "a maxim very current in the world". The discussion continues into T 3.2.12 which is otherwise devoted to a discussion of female chastity. The maxim is one, we are told, that not many politicians will publicly avow but it is, says Hume, certainly the practice of all ages (T 3.2.11, 568). The maxim is this: 
"that there is a system of morals calculated for princes, much more free than that which ought to govern private persons" (ibid, italics in original).

Hume explains what he takes this maxim to mean. He says that the duty to keep promises (and respect property) applies to states as well as individual persons. This means that the same rules govern the interactions of states as govern the interactions of individual persons. This is because states are like individual persons in certain important respects. In particular they are given to "selfishness and ambition" but, nevertheless, need to find ways to cooperate and coordinate with one another (ibid,567). But what will shock certain philosophers, says Hume, is that these rules have less "force" for states than they do for individual persons. That is, they are in some way less stringent. He explains what he means by saying that they can be "lawfully transgress'd from a more trivial motive" (ibid, 568).

Hume does not take himself to be merely reporting this maxim. He also seems to endorse it. Although it will be shocking to some philosophers he thinks that it will "be easy to defend" by appeal to his general theory of justice and promising (ibid).

Despite the assurance that it will be easy to defend, Hume's defence of the maxim has been mostly rejected by those few commentators who discuss it at all (see section 3, below). Indeed, some commentators, such as Marshall Cohen and to a lesser extent JL Mackie, trace the source of Hume's error back to his conventionalist account of justice and promising. Rather than offering further support for Treaty as Humean Promise, then, Hume's defence of the shocking maxim seems to call it into question. If the shocking maxim follows from the underlying theory, critics suggest, we have some reason to reject the underlying theory. 
My aim in this chapter is to present what I take to be the most plausible reading of Hume's defence of the shocking maxim. In doing so I will defend Treaty as Humean Promise, and Hume's position more generally, from criticisms made of it by Marshall Cohen (sections 4 and 5). I choose Cohen because he presents the clearest attack on the view I have called Treaty as Humean Promise. The shocking maxim, I suggest, is based upon the idea that the moral force possessed by a conventional rule bears some proportionate relation to the importance of the interests protected and promoted by that rule. By an analogy with a conventional rule prohibiting checking a text-message in company, I argue that Hume's position is plausible (section 7). States could survive better than could individual persons if they never had a social convention of promising in the first place. However, Hume does not appear to consider the different interests that states, or individual persons for that matter, can have in particular promises being kept given that a promise has been made.

Whether a state has a strong interest in having a social convention of promising available or a strong interest in seeing particular promises kept is, I suggest, ultimately an empirical question. I finish the chapter by offering some considerations that support the shocking maxim (section 8). I do this with a proviso. What Hume calls the "practice of the world" changes over time and the truth of the shocking maxim will change with it. This is not a problem for Hume. Any problem with the shocking maxim cannot be traced back to some flaw in Treaty as Humean Promise. Instead, insofar as there is a problem with the shocking maxim, as commentators suggest there is, it lies in the different conditions of $18^{\text {th }}$ century and late $20^{\text {th }}$ and early $21^{\text {st }}$ century international affairs. This is the kind of problem that I suspect Hume the empiricist would gladly own. 


\section{What Hume does and does not say and some shocked philosophers}

\section{2a. Hume's reasons}

What reason does Hume give for thinking that the 'system of morals' has less force for princes than it does for states? Hume suggests that the reason why the system of morals has less force is because international relations just do not matter as much as relations amongst individual persons. States, unlike individual persons, can survive without the conventional rules of promising (as well as justice more generally) (T 3.2.11, 568 - 569). This means that states have less of an interest than individuals do in having such conventional rules available to them in the first place. Hume thinks that because this interest is less important for states the moral obligation, which "arises from" this interest, "must partake of its weakness" (ibid, 569). As to how much weaker international morality is than morality for individual persons Hume cannot say precisely. This is because philosophy is not up to this task. Instead we must look to the "practice of the world" for our answer (ibid).

\section{2b. What Hume isn't saying}

Hume is not arguing, as some theorists do, that moral rules do not apply at all to international affairs. ${ }^{88}$ The rules are the same as they are for individual persons. There is also no reason to think that Hume believes that these rules have different criteria of

\footnotetext{
${ }^{88}$ The view that morality does not apply to international affairs, or that different moral rules, apply to international affairs is often associated with so-called political realism. I discuss this view in more detail in chapter 7. Representative of such views is Hans Morgenthau's claim that "[u]niversal moral principles cannot be applied to the actions of states" (Morgenthau 1954, 9). Hume does not agree.
} 
application (Ellin 1988, 119). But Hume clearly differs from those who think that the same moral rules apply with the same force, or stringency, for both princes and individual persons ${ }^{89} \mathrm{He}$ also differs, at least in the Treatise, from those who think that princes may violate moral rules when suitably important matters of state are at issue. ${ }^{90}$

It is important to reiterate one point. Hume does not say that it is morally permissible for princes to violate a treaty on a whim or merely because it is expedient to do so. This fact can be easily overlooked. Marshall Cohen, for example, asks, rhetorically, "surely, Hume cannot think it would be acceptable for a prince to repudiate his obligations under a treaty after the other side has performed?" (Cohen 1984, 337). The answer to Cohen's question is that Hume does not think it would be acceptable. He says that "no one of ever so corrupt morals will approve of a prince, who voluntarily, and of his own accord, breaks his word, or violates any treaty" (T 3.2.11, 568 - 569). Hume's claims about the force of international morality are always comparative. Its force is weaker than morality for individual persons. But this should not be taken to mean that it has no force.

\section{Certain shocked philosophers}

Hume's comments on the laws of nations in the Treatise have not been widely endorsed by commentators. Marshall Cohen, for example, presents a vehement attack on Hume's theory which, he thinks, should simply be rejected as immoral (Cohen 1984, 329 - 330). I return to Cohen below. Jonathan Harrison (1981, sec. xi) and JL Mackie (1980, chap. 6,

${ }^{89}$ This is the view of Marshall Cohen, as we shall see.

${ }^{90}$ Bernard Williams, for example, endorses this view (Williams 1978, 62). In other writings Hume endorses it too (EPM 4, 206; cf. Walzer 1977, 18 - 19 for a discussion of this view in Hume's History). 
sec. 5) both think that Hume is correct that the shocking maxim does reflect the "practice of all ages" but that this is to be regretted. The problem, they think, is that states have less incentive to keep their treaties (and generally obey the rules of justice) than do individual persons. It is not, as Hume thinks, that the interests at stake are less serious. The appropriate remedy for this, according to both Harrison and Mackie, is some kind of strengthening of world government to keep princes in line, although they disagree about just how strong such a world government should be (Harrison 1981, 230; Mackie 1980, 115). Joseph Ellin (1988) is much more sympathetic to Hume's claims. Nevertheless he complains that Hume adopts the perspective of those countries that do not expect to be harmed by violations of the rules of justice and promising, such as the USA now, and wrongly ignores the perspective (and interests) of relatively vulnerable countries that depend upon those rules more heavily (Ellin 1988, 146 -148). Ellin also notes that Hume is wrong to leave the question of the proper force of the prince's duties up to the "practice of the world", given the extent to which princes will seek to manipulate that practice to their own ends (ibid, 149).

In the next section of the Treatise, 3.2.12, Hume does concede that some people may not be convinced by his argument (T 3.2.12, 570). In order to further support his claims Hume draws parallels between his discussion of international affairs and the obligations that women have to be chaste and modest. The obligations that men have to be chaste, Hume thinks, "bear nearly the same proportion to the obligation of women, as the obligations of the law of nations do to those of the law of nature" (ibid, 572). That is, men have the same obligations to be chaste as do women but, Hume says, these obligations have less force for men than women. This is because the social interest in their chastity is not as strong as it is for women and so the moral obligation to be chaste is not as strong. 
Presumably the maxim 'there is a system of sexual morals calculated for men, much more free than that which ought to govern women' would have been considered less shocking, and easier to accept, by Hume's contemporaries than the maxim permitting greater leniency for princes than private persons. However although Hume may still, sadly, be right to point out sexual double standards I suspect that few would be willing to accept the 'practice of the world' in this regard as properly definitive of sexual morality. Hume's argument from analogy is not convincing. Just because princes treat treaties more lightly than individuals treat their promises and just because men want to be sure that they have paternity of the children they raise (ibid, 570) but cannot control themselves sufficiently to achieve this end, it does not follow that princes are justified in their behaviour or that men are justified in imposing restrictive conventions upon the other half of the population.

Hume's defence of the shocking maxim, then, looks to be in some difficulty. It is rejected by most of those philosophers who bother to discuss it at all. ${ }^{91}$ And the appeal to a similar maxim with respect to female chastity is less than convincing. In order to begin the task

\footnotetext{
${ }^{91}$ As I note above Joseph Ellin gives a largely sympathetic reading of Hume's argument much of which I am in agreement with. More recently Russell Hardin has defended Hume (Hardin 2007, 130 - 132). If anything, however, Hardin attempts to defend too much. Like Cohen, Hardin thinks that Hume is saying that "promises between national leaders - treaties - are violated with impunity" (ibid 130). As I note above Hume just does not think that the maxim authorizes this or that this is a good description of what actually happens. I have already offered one quotation to support this. Here is another; no one, says Hume, "will...be so extravagant as to assert, that the most solemn treaties have no force among princes"
} (T 3.2.11, 568). 
of presenting a plausible reading of Hume's defence of the shocking maxim I will focus in the first instance on the arguments made by Marshall Cohen.

\section{Marshall Cohen's rejection of Treaty as Humean Promise}

Marshall Cohen criticises Hume's views on international affairs in his paper Moral Skepticism and international Relations. Hume's position, which Cohen terms "moderate skepticism", should, Cohen argues, be condemned as immoral. Morality applies "with equal force to princes and private persons" (Cohen 1984, 329 - 330). What, then, are Cohen's criticisms of Hume's theory?

Firstly, Cohen rejects the idea that social conventions are essential for promises to be made. Cohen says that he agrees with TM Scanlon and also John Locke that binding promises can be made in the absence of a shared social convention of promising. Because Hume does not recognize this his "entire project" is dismissed as "misguided" (Cohen 1984, 333). I have already discussed the reasons for thinking, with Hume, that social conventions are essential to promise making. Of course, this theory of promising might be rejected. But even if it is it is hard to see how Cohen's criticism has much to do with Hume's claim about the supposed relative weakness of the prince's obligation to keep a promise when compared to the individual person's. Hume is simply not denying that princes can make promises. It is not clear how the details of the theory of promising we endorse alter this. Or, at least, Cohen does not make this clear.

Secondly, Cohen criticises Hume for limiting his definition of justice to matters relating to personal property and the stability of external possessions. As we have seen, Hume's main example of a promise is an exchange of labour. His other examples include borrowing money, buying the contents of a house, and purchasing wine. Cohen argues 
that questions of justice arise over a much broader set of issues than Hume recognizes. Cohen offers the examples of "coerced sex, forced labor, and unprovoked and unnecessary killing" which are all "unjust (or morally unacceptable in some other way) even in the state of nature" (ibid, 332, emphasis added).

Let me briefly reject Cohen's invocation of the 'state of nature' in this context. Unlike Hobbes or Locke, Hume does not think that the state of nature is marked by an absence of a government able to enforce common rules (Ellin 1988, 137). For Hume the state of nature, which probably never existed, is marked by an absence of conventional rules that actors reliably follow. Given that Hume thinks that the same rules apply in international affairs as amongst individual persons and that princes can be relied upon to "perform their part" (T 3.2.11, 568), Cohen's point about the status of morality in the state of nature is ultimately neither here nor there so far as Hume is concerned.

Of more concern for Hume's theory is the claim that it leaves us no moral grounds upon which to condemn rape, slavery, and murder. It is true that Hume uses a very narrow definition of justice. Cohen seems to take a far more expansive view that whatever is the morally best system, all things considered, should be called 'just' and hence anything that deviates from this, including rape, slavery, and murder, is unjust. Perhaps Cohen's terminology is preferable to Hume's. But we should not assume that Hume thinks that rape, slavery, and murder are not morally unacceptable even though, by his definition, they are not unjust. For Hume rape, slavery and murder are, as Cohen puts it, "morally unacceptable in some other way".

Hume clearly thinks that we can make disinterested, that is, moral, judgments about actions and character traits that have nothing to do with social conventions. Furthermore, he thinks that we can be reliably moved to act in accordance with these moral judgments. 
Now, we do not have to accept Hume's sentimentalist theory of morality and Cohen, preferring Locke's 'natural morality', does not. Nevertheless, Hume concurs with Cohen that "[w]ilful murder" is "vicious" (T 1.3.1, 469) and that slavery is "cruel and oppressive" (Hume 1987b, 383). There are things we should not do (and some things we should do) even in the absence of social conventions and also, presumably, whatever else it is that we have promised to do.

Now, perhaps what Hume thinks is that the moral rules prohibiting rape, enslavement, and murder do not apply with as much force to princes as they do to individual persons. So, for example, Hume might hold that it is more permissible to assassinate a government official from a rival state than it would be to kill someone in the street. Hume does not discuss this kind of case because he seems to only be talking about the rules of social conventions and not our non-conventional moral obligations. Nonetheless it is possible that Hume might have agreed that assassinating a government official is more permissible than killing someone in the street. This would be a provocative position to hold but it does not have anything to do with Cohen's criticism, which seems to be predicated upon the mistaken belief that Hume thinks that there is just no moral prohibition on wilful murder for princes. But, as we have seen, Hume is not committed to any such view.

Thirdly, Cohen argues that Hume should not think that just because a set of conventional rules operates amongst a group it follows that these rules are morally acceptable. He claims that we will "have to judge the rules that inform these conventions, and ultimately the actions of those who invoke them, by the natural moral requirements Hume refuses to acknowledge" (Cohen 1984, 334). 
Although this may be a general problem for Hume's view, and I return to it below, it does not seem to have much to do with whether the shocking maxim is correct or not. If Hume has mistakenly conflated the social conventional rules as they happen to exist with the requirements of morality, as Cohen charges, then he has done so for both princes and private individuals. This is because Hume thinks that the rules are the same. They have the same domain of application. Again, it is unclear what Cohen's criticism has to do with the shocking maxim. If the social conventional rules are found to be lacking, say by applying Cohen's 'natural moral requirements', then it is hard to see how it is a problem that princes violate those rules more readily than do individual persons except that they both should, presumably, violate them all of the time.

Still, Cohen may be correct to complain that Hume is mistaken to think that social conventions are morally acceptable just because they happen to have been adopted by some group, say princes. Cohen gives an example of an instance where there does seem to be some disparity between the rules of a convention, in this case the treaty making convention, and our considered moral judgments. Cohen notes that it used to be a part of the treaty making convention that treaties were considered valid and binding if they were signed under coercive threats by another party. But, Cohen notes, we no longer think that this is morally acceptable and, indeed, the social convention has now changed to reflect this fact (ibid). Nevertheless, Hume apparently needs to accept that in the past a treaty based upon coercion should, indeed, have been kept just because that was the practice amongst princes at that time. But just because a social convention says that an action is acceptable, goes the complaint, it does not follow that it is. But Hume is apparently committed to just this view. 
Is this a fair complaint? I do not think that it is. Hume does not seem to think that a set of conventional rules are morally acceptable merely because they happen to have been adopted. For example, he criticizes the $18^{\text {th }}$ century social convention of duelling in order to uphold honour. Hume condemns this convention as "pernicious". This is because all the convention of duelling does is to confuse "honour" with morality, or virtue, so that even those with "the most shameful and dangerous vices" are wrongly considered men of honour (Hume 1987c, 626). Hume here engages in moral condemnation of a particular social convention.

Hume's complaint against duelling is not that there has not been some genuine wrong done that has occasioned the duel or that the desire to uphold one's honour is not, in some way at least, noble. The complaint is, rather, that the convention of duelling is not an appropriate means of realising the very purpose the duel is supposed to achieve, upholding (genuine) honour. We can identify this purpose independently of the social convention that is supposed to realise it. In this case Hume thinks that the ends of duelling are, at least in part, moral ends and it is appropriate to evaluate the social convention of duelling according to how well it realises those ends. So, as far as Hume is concerned, I

think that we have some reason to reject Cohen's charge for at least some social conventions. But is what is true of duelling also true of promising?

\section{The deep conventionality of promising}

\section{Deep conventions}

The social convention of promising differs from that of duelling in important respects. The social convention of duelling seems to be arbitrary and historically contingent in a way that the social convention of promising is not. Duelling was closely tied to complex 
notions of nobility and class. Undoubtedly there were some perceived interests, needs, and functions served (badly, thought Hume) by the social convention of duelling but the social convention itself appears to have been a response to contingent aspects of the social world of Europe (and some other places) at a particular point in history (Appiah 2010, chap. 1). But this does not seem to be true of the social convention of promising. Promising seems to be a response to much more deep-seated aspects of our social world, and perhaps human nature, than duelling. ${ }^{92}$ It is easy to imagine a world with or without duelling (after all one is Hume's world and the other is ours) but it is far more difficult, and far more distant from our lived experience, to imagine a world without promising (see Marmor 2009, 138; Sheinman 2011b, 481). ${ }^{93}$ Hume puts the matter as follows. Although he is talking about justice what he says is also true (perhaps more so) of promising:

“Tho' the rules of justice be artificial [i.e., a matter of social convention], they are not arbitrary. Nor is the expression improper to call them Laws of Nature; if by

\footnotetext{
${ }^{92}$ I suspect that what is true of duelling is true of chastity too, although it may not have seemed that way to Hume. The conventional rules concerning chastity seem, with the vantage of history, contingent in a way that I suggest promising is not. Hume is correct, I think, to see chastity as an 'artificial virtue', a matter of social convention. But I do not think that it belongs with the artificial virtues of justice and fidelity to promises which (as I note) do seem to be "inseparable from the species" in a way that is just not true of female chastity.
}

\footnotetext{
${ }^{93}$ Promises, or similar sorts of oaths, seem to be universal. It seems to be central to certain forms of human agency (Marmor 2009, 138; Sheinman 2011b, 481). This is not true of duelling (although upholding personal respect and standing may be).
} 
natural we understand what is common to the species, or...what is inseparable from the species" (T 3.2.2, 484, emphasis in original).

There are degrees of conventionality (see Sheinman 2011b, 484). Andrei Marmor, for example, notes that there are conventional rules of various games. The conventions of playing cricket, which make playing cricket, rather than something else, possible, serve a certain purpose (for example having fun). We can easily imagine some alternative to the conventions that constitute playing cricket and which serves the same basic purpose. You and I could change the rules of cricket in such a way that, at some point, we end up with a different game. $^{94}$ The game of cricket is not 'common to the species' nor is it 'inseparable' from it. However, Marmor suggests that, through playing games like cricket, we indirectly participate in a 'deeper convention'. This is the convention of game playing. We participate in this convention indirectly, by playing particular examples of games, like cricket. 'Game playing' is a deeper convention in that it speaks to more basic human needs. Although we can imagine a world without the particular game of cricket, as impoverished as it would be, or darts, or football, and so on, it is much more difficult to imagine a world (or even society) without any games at all. People in such a world, Marmor suggests, would be very different from us (Marmor 2009, 73).

\footnotetext{
${ }^{94}$ Purists might say, for example, that the ' $20 / 20$ ' format is not an example of the game of cricket at all. Exactly when cricket stops being cricket and becomes a different game is difficult to state with any precision. We could leave this up to the "practice of the world". As with Humean princes, however, we should be wary of the motives of cricket's administrators.
} 
Hume seems to be making much the same point about promising that Marmor makes about games. ${ }^{95}$ Although there may have been some alternative conventional rules that would achieve basically the same needs and purposes as promising, that would allow us to coordinate and cooperate with others by committing ourselves to do just that, the social convention of promising that we have is so closely linked to certain basic needs and interests that it is difficult to imagine quite what this alternative might be or what alternative form it might take (see Sheinman 2011b, 482 - 483). It is easy enough, however, to imagine slightly different conventional ways of going about making different kinds of promises.

Just as one can indirectly participate in the social convention of game-playing by playing a particular game, say cricket or darts, so too can one participate in the social convention of promising in various ways (see ibid, 485). A contract to transfer land may require a symbolic transfer of a handful of earth from that land in one place and just a duly witnessed signature in another, some marriages invoke a deity and some do not, and states can enter into treaties (which are published by the UN) or Memorandums of Understanding (which are not), and so on. The point is that these are different, conventional, instances of the deeper social convention of promising whereby actors selfimpose reasons for action by means of communicating their intention to impose those

\footnotetext{
95 Interestingly, Marmor denies that promising is conventional precisely on the grounds that there seems to be no alternative we could have followed instead, achieving basically the same functions as those achieved by promising. As Hanoch Sheinman notes, however, Marmor thinks that it is possible for some other 'deep convention' to replace the game-playing convention but that it is hard to see what this might be, harder, in fact, than imagining a convention of something like promising that would achieve basically the same purpose as promising (Sheinman 2011b, $479-485$ ).
} 
reasons. It is possible to alter at least some, but not all, of the rules of the game of cricket without thereby ceasing to play a game. It is possible to alter at least some, but not all, of the rules of treaty making without thereby ceasing to make a promise.

Now, some of the particular rules, of cricket, say, or treaty making, may be useless, trivial, or even morally contemptible in some way. Indeed, some rules may be such that they do not achieve the purposes for which the social convention is intended. We saw that Hume thought that the social convention of duelling was like this. Hume also thinks that a conventional rule that would require us to keep our promises even if these were extracted by threat of force, say by an armed robber, is like this. He thinks this even though he also thinks such an instance is, really, not so very different from a case in which someone is, as we might say, coerced by the circumstance of being "dangerously wounded" into promising to pay a doctor a large sum of money to cure him. Hume suggests that the dangerously wounded man should keep his promise whilst the victim of the robbery need not. The difference in these judgments, according to Hume, can be discovered by reflection upon "public interest and convenience" (T 3.2.5, 525). Now, Hume might be wrong to distinguish between different kinds of coercion in this manner. ${ }^{96}$

\footnotetext{
${ }^{96}$ Some people think, for example, that for a promise to be binding it is not enough that the threat of force not be used. It must also be the case that people must not be coerced by a lack of feasible alternatives (as Hume's dangerously wounded person is). Michael Sandel, for example, holds such a view (Sandel 2012).
}

The acceptability of the convention mentioned by Cohen that allowed treaties to be binding even when extracted under the threat of force turns upon two considerations;

Firstly, and most straightforwardly, it may be considered morally acceptable to annihilate one's vanquished opponent after a war. If you think this then there is no more problem with offering a treaty 
And he might be wrong to distinguish between them based upon considerations of the "public interest and convenience". The point is, however, that contra Cohen, there seems to be no need to think that Hume holds that any particular instantiation of the social convention of promising is morally acceptable, or immune to moral criticism, just because it has somehow managed to be adopted. The defender of Treaty as Humean Promise is not committed to such a view either.

than there is, say, in inducing someone to come and work for you by offering them a contract promising them a huge salary, if only they will sign it.

Secondly, one might believe that it is not morally acceptable to annihilate one's vanquished opponent and that a 'treaty' offered in the circumstances is really just a threat. It is a threat because, if the terms of the treaty are not accepted, then the aggressor will leave the vanquished state worse off than they should be. (For a discussion of the appropriate baseline to distinguish offers and threats see Nozick 1969, 444) There may yet still be reasons to hold that such treaties are binding if, for example, one is aware that states are generally so depraved that they will seek to annihilate one another in any case and that allowing treaties extracted by threat to be binding will help to mitigate far worse moral disaster.

If annihilating one's opponent is morally unacceptable (and I think that it is) then the problem lies with general beliefs about ius post bellum rather than treaty making per se. Denying vanquished states the right to enter into binding treaties to ameliorate their situation does not solve the underlying injustice. It merely denies states an effective means of ameliorating a bad situation.

I think that the considerations regarding coerced treaties (and promises) are, in either case, far more complex than Cohen suggests. Hume's discussion in the Treatise seems to me a good place to begin thinking seriously about them. A more recent discussion, arguing that treaties signed under unjust coercion should be considered binding, is offered by Daniel Schwartz $(2012,273$ - 292). 


\section{Back to the shocking maxim}

The idea that some social conventions are 'deep' conventions, in the sense that they seem to realise certain fundamental needs, interests, and purposes of people can, I think, help us to understand the claim that Hume is making when he endorses the shocking maxim. Here is what Hume says when comparing states and individual persons:

"tho' the intercourse of different states be advantageous, and even sometimes necessary, yet it is not so necessary nor so advantageous as that among individuals, without which 'tis utterly impossible for human nature ever to subsist" (T 3.2.11, 569).

Promising, and the rules of justice more generally, are central to "human nature" in a way that, Hume thinks, is not also true of states. Individual persons typically rely upon one another very heavily. We use promises to coordinate and cooperate (as Hume's two farmers do). Promises enable us to make choices which are meaningful and lasting, allowing us to commit ourselves to long-term projects and inter-personal relationships that help to give shape to our lives (see Fried 1981, 20 - 21; Raz 1986, 173 - 176; and Shiffrin 2008, 500).

States can use treaties for similar purposes. I have noted that they can be used to facilitate useful coordination and cooperation in much the same way that Hume's two farmers use a promise to achieve the same ends. As Hume notes, for states in the absence of promises "there can be no leagues or alliances" (or, at least, such leagues and alliances would be much rarer because much harder to achieve) (T 5.3.11, 567). But Hume clearly thinks that states do not depend upon promises as heavily as do individual persons. They are not as central to the life of states, or the citizens of the state, as promises are to individual 
persons. Part of the reason for this is, presumably, that states are, as Hume puts it, "very different" from individual persons in some respects. Marmor's people lacking a social convention of game playing must be very different from us, psychologically and socially (Marmor 2009, 73; Sheinman 2011b, 484). States are, on Hume's account, not as alien from us as Marmor's game-less creatures but, nevertheless, they do differ from us insofar as they are apparently less dependent upon their promises and, hence, the social convention of promising.

Hume claims that this means that because states have less interest in the social convention of promising than do individual persons (in Hume's terms their 'natural obligation' is weaker) that the 'moral obligation', which is derived from it, must be weaker too. Because of this "we must necessarily give a greater indulgence to a prince or minister, who deceives another; than to a private gentleman, who breaks his word of honour" ( $T$ $3.2 .11,569)$.

In order to assess Hume's claim we must answer two questions. Firstly, is Hume correct to say that the moral obligation to follow the rules of a social convention is proportional to the interests that the social convention helps protect or realise? And secondly, if the answer to the first question is 'yes', is Hume correct to say that states do have less interest in treaty making (and compliance) than individuals do in promising?

\section{Hume's principle of proportional obligation}

\section{7a. Proportionality and politeness}

In section 8 of the Second Enquiry Hume discusses a set of social conventions which he calls "the rules of Good Manners or Politeness" (EPM sec. 8, 261 - 267 (quotation at 261)). 
As we have seen, for Hume the social convention of promising, like the conventions of justice more generally, allows us to redirect our self-interest into both socially and individually useful behaviour. The rules of polite behaviour, on the other hand, allow us, when in company with one another, to overcome "the eternal contrarieties...of men's pride and self-conceit...in order to facilitate the intercourse of minds, and an undisturbed commerce and conversation" (ibid). Hume focuses on the importance of appearances to polite behaviour. For Hume the point of the social conventions of polite behaviour is to create the appearance for others that one is not selfish or self-conceited whatever the reality (Buss 1999, 799). JL Mackie has called good manners "minor artificial virtues" for Hume (Mackie 1980, 125) and this is, I think, a good way of summing up Hume's view that displays of bad manners "are nothing but smaller vices" (EPM 8, 266).

Now, the conventions of good manners are a matter of morality insofar as they help to promote and protect certain other-regarding ends. So, for example, we are told that in Spain the owner of a house leaves before his guest whilst, in other countries, he leaves after his guest. Although the convention differs both aim to realise a suitable "deference and regard" for the guest (ibid, 262). Hume's own account of why this counts as moral, and a sign of good character, relies upon his sentimentalist moral theory. The emotional responses we have to certain behaviour that we witness or hear about determine whether those actions are moral or immoral. What enables this to take place at all is our faculty of sympathy, a mechanism which provokes us to share in the emotional responses of others. It is the operation of sympathy, thinks Hume, together with the possibility of adopting a disinterested, generalized perspective which makes the kind of impartial judgment required for genuinely moral judgment (T 3.1.2, 470 - 476). 
Hume tends to explain the interests of persons in terms of their welfare (in particular pleasure, pain, and general 'utility') but we do not necessarily need to limit ourselves in this way to understand Hume's point about good manners. We might think, for example, that the rules about allowing one's guest out first, or last, are a way of showing appropriate respect for the dignity of a person irrespective of considerations of pleasure, pain, or general utility. In other words, to say that rules of good manners (or any other social convention) protect and realise certain interests does not commit us to any particular way of measuring the importance of these interests (Ellin 1988, 143).

Some of the conventional rules of good manners seem to be more minor, morally speaking, than others. Passing the port to the left or using the correct fork for the entree seems far more trivial than, say, expressing fitting sentiments in the appropriate manner to a friend who has suffered bereavement. Typically we make distinctions about the stringency of our moral reasons for action dependent upon the importance of the interests that certain forms of behaviour are supposed to protect or promote. For example, there are social conventions regarding appropriate text-messaging whilst in company. The rule is, in general, not to do so as it shows a lack of proper concern for those one is with. ${ }^{97}$ Nevertheless it does seem to be worse, morally speaking, to respond to a text-message whilst comforting a bereaved friend than it is to do so when out for dinner for with one's friends. One explanation for the difference lies in the interests that the social convention regarding text-messaging during a conversation protects in each

\footnotetext{
${ }^{97}$ See, for example, the $3^{\text {rd }}$ 'Golden Rule' of texting at 'Seven ways to Text with Graciousness and Savvy', http://www.mannersmentor.com/only-at-work/seven-ways-to-text-with-graciousness-and-savvy
} (accessed 05/06/2014). 
instance. To interrupt a bereaved friend in order to check a text message is to take their suffering, and the friendship, inappropriately lightly. Similar considerations apply when checking a text message when out for dinner with friends. Here, however, there is (I am assuming) no suffering to fail to respond to. It is disrespectful to check the text message in both instances but worse, because more upsetting to the bereaved friend, in the former case than the latter. The moral wrong done in violating the convention is proportional to the interests served by that convention. Let us call this Hume's 'principle of proportional obligation'. 98

Now, the social convention of promising differs from the social conventions of good manners in some important respects. For one thing, of course, the social convention of promising is not a 'minor artificial virtue' for Hume. I have already noted that it seems to be the case that the social convention of promising is linked to some fundamental needs and purposes of human beings. The social convention is a deep one although it manifests itself in more localized, and less deep, iterations. One thing that this means is that there are certain features of the social convention of promising that we cannot dispense with if we want to achieve the purpose of promising at all. This does not seem to be the case with the rules of good manners. For all that they can help us to protect morally important interests and realise morally important ends, these ends may, in some circumstances, be better (perhaps only) achieved by flouting the convention in certain instances. The purpose of promising can be achieved, perhaps with some difficulty, without making a

\footnotetext{
98 Some reference to such a principle can be found in Harrison $(1981,235)$ although it is not very clearly stated. A clearer statement of a version of what I call the principle of proportional obligation can be found in Ellin (1988, 128 and 144 - 145). Like Harrison, however, and unlike Ellin, I think that Hume makes an error in failing to properly consider the expectations generated by any individual treaty.
} 
promise. Nevertheless, once the promise has been made, and the social convention invoked, achieving this aim just means keeping the promise.

The point that I want to make is not that some social conventions, say promising, seem much more important than others, for example those relating to good manners, although this is no doubt true. Rather the conventional rules requiring promise keeping are like the conventional rules regarding appropriate text-message checking in an important sense. The rules of text-message checking are the same whether one is talking to a friend at dinner or comforting a bereaved friend: do not check the phone when in company. However, because of the nature of the interests protected, the violation of these rules is more serious in the latter case than the former. We should be more lenient in our moral judgment of someone who checks his phone during a dinner date than we are when he does so whilst comforting a bereaved friend. Looking only at the conventional rules, and not paying attention to the interests at stake, one may miss this distinction (ibid, 146 147). And this, Hume claims, is the case with the social convention of promising. As with the text-message example, the same kinds of interest are at stake when the rules of promising are applied to individual persons as to states. But the interests, Hume thinks, are not as important for states as they are for individual persons. Because of this we should be more lenient in our moral judgment of the prince "who deceives another" than we are of the individual person "who breaks his word of honour" (T 3.2.11, 569). Accordingly, the moral reasons (the moral obligation as Hume puts it) apply with less force, that is, less stringency, for princes. They may be permissibly "transgress'd from a more trivial motive" just as one might justifiably interrupt a dinner date to check one's phone on a more trivial pretext than one could when comforting the bereaved friend. 
This, I think, is the most plausible reading of Hume's claims about the differing strength of our moral obligations relative to the strength of our interests at $\mathrm{T}$ 3.2.11 and $\mathrm{T}$ 3.2.12. And I think that Hume is correct to think that the moral reasons to do something can apply equally to different agents but with different force. Nor is it implausible to say, as Hume does, that the force of the moral reasons depends upon the interest that those rules protect. This I take to be all that Hume means when he says that because the "natural obligation to justice, among different states, is not so strong as among individuals, the moral obligation, which arises from it, must partake of its weakness" (T 3.2.11, 569, emphasis in original). Hume does not think that the force of the moral obligation varies depending upon how willing princes are to follow the rules on each occasion, as both Harrison and Mackie suggest. And he does not think, as Cohen suggests, that whatever it is that princes happen to do must be considered moral.

I want to make one final point before moving on to see if Hume is correct to think that states do have less interest in seeing promises kept than individual persons. I have followed Hume's claim that the social convention of promising is central to promisemaking. This is because I am, of course, trying to explain Hume's position and it is what he thinks. I also think that it is correct. Nevertheless, as we saw, some theorists, such as Marshall Cohen, reject Hume's conventional account of promising. I do not think that this makes much difference to the plausibility of Hume's claim that the strength of one's moral obligations are in proportion to the interests protected, or promoted, by a set of rules. Those rules can be conventional, as Hume thinks (and I agree), or they can be the kind of 'natural' rules of morality endorsed by Cohen. In either case Hume's claim is that the importance of the interests protected, or promoted, by those rules matters in ascertaining 
how strong our moral obligation is to follow those rules. Whether this is correct or not does not stand or fall on the provenance of the rules under consideration.

I have suggested that Hume should be read as making a claim about how the interests protected, or promoted, by a set of conventional rules determine the force of the moral reasons we have to comply with those rules. In order to determine this we must look not only at the rules themselves but also the agents and patients and the interest that those rules protect. Applied to the rules of good manners, and text-message checking, I suggested that Hume's claim is plausible. The same kind of reasoning, I suggested, is applied by Hume to account for the supposed difference in the force of the moral obligation to keep a promise when it is made by an individual person and when it is made, in the form of a treaty, by a state. It is this reasoning that it is at work, I think, when Hume endorses the shocking maxim. But is Hume correct to apply his principle of proportional obligation to the relations between states in the way that he does?

\section{7b. Which interests?}

According to Hume a promisor has a self-interested reason to keep her promise. This, I suggested, is a self-imposed reason to keep the promise. It is what gives the promise whatever credibility it has. The strength of this interest depends upon the importance that the promisor attaches to maintaining her future access to the social convention of promising. One thing that makes this self-interested reason important is that it can help us to explain how we can make a promise, and feel we ought to keep it, even when nothing of value appears to be at stake in doing so. In particular there may be no important interests of the promisee at stake in the promise. For example Hume might make a perfectly good promise to count the blades of grass on Adam Smith's lawn. 
Once the promise has been made, and the promisee has accepted the promise, we are in a position to explain how the promise can be a way of triggering more general moral obligations. I gave two examples that are common in the literature on promising (and are mentioned by Hume) ${ }^{99}$. Firstly, a promise can trigger a general moral obligation not to undermine or free-ride upon a useful social convention. The idea here is that all the users of the social convention of promising have some interest in seeing it maintained and not free-ridden upon and it is wrong to disappoint these interests. Secondly, a promise can generate specific expectations in the promisee, expectations that it would be wrong to disappoint. A promise normally generates a high degree of responsibility for the agent for actions that undermine these expectations and interests. It typically requires a very good excuse to get out of keeping a promise. Hume's claim is that princes do not need such good excuses to permissibly get out of complying with a treaty. This is because the interests and expectations of others are not as important in international affairs as they are amongst private persons.

Now, I think that central to Hume's argument is the interest that he thinks that each of us has in not seeing the social convention of promising undermined. His explanation for why it is in the self-interest of each person to uphold the rules of justice, by not stealing for example, is that "disorder and confusion [would] follow upon every breach of the rules" (T 3.2.2, 499). Each particular violation of the rules has an effect upon the behaviour of others. This, of course, has consequences for each person, including the would-be rule breaker, who is better off having the rules than not having the rules. In this way, Hume thinks, the interest of each of us in having rules of justice also translates into an interest

\footnotetext{
${ }^{99}$ See chapter 3 for a discussion of these general moral obligations. See T 3.2.5 (for Hume's practiceconsequentialism) and EPM App 3, 310 (for Hume's discussion of what I call the 'expectations account').
} 
that each of us has in following these rules on each occasion. Applied to promising this would become the view that the self-interested reasons that we have to keep our promises are the same as the interests that each of us has in maintaining the convention of promising.

I have not relied upon this version of Hume's argument in setting out, and defending, the Humean view of promises. It is not plausible to think that each violation of the conventional rules is such that 'disorder and confusion' would result. In many instances the gains that an agent might expect to make by breaking a promise will outweigh the relatively small amount of damage he will do to the social convention of promising itself. This is the argument of the sensible knave of the Second Enquiry who reasons that "an act of iniquity or infidelity will make a considerable addition to his fortune, without causing any considerable breach in the social union and confederacy" (EPM 9.2, 282). Hume has an answer to the knave which need not detain us here except to say that it is not that each broken promise or act of injustice will undermine the relevant social convention. In explaining the Humean view of promising I have noted Hume's view that we put our reputation on the line each time we make a promise. It is in our self-interest to keep a promise insofar as we want to maintain our own access to the social convention. ${ }^{100}$

Although I do not think that Hume's 'disorder and chaos' argument is plausible it is, I think, the argument that Hume has in mind when he endorses the shocking maxim. Each state, thinks Hume, has less interest in following the conventional rules of promising on

\footnotetext{
${ }^{100}$ It is not clear whether Hume sees any significant difference between this argument and the argument that each instance of promise breaking invites 'disorder and chaos.' They are, however, quite different claims.
} 
each occasion than does each individual person. According to the 'disorder and chaos' argument this is because all of them have less of an interest than do individual persons in having such rules available. It is in this way that the strength of the natural obligation, that is the interest that each state has in following the rules, is linked by Hume directly to the strength of their moral obligation which is based upon the importance of the interest that each state has in having such rules regulate their joint affairs. The reason that the moral obligation to comply with treaties is weaker than the moral obligation that individual persons have to keep promises is because it is not as important that there be any such rules in the former case as the latter in the first place.

Ultimately the close link that Hume attempts to establish between the interest that each state has in having common rules and in following those rules on each occasion is not plausible. In this respect, at least, the sensible knave is correct. It is more plausible to simply suggest that the obligation to follow a set of conventional rules is relatively weak where it does not matter very much whether or not those rules exist in the first place. Insofar as the conventional rules against treaty violation do not protect very serious interests (because states could survive without those rules) it is not a very serious matter if princes break those rules (see Ellin 188, 141). (Remember that this is all relative, for Hume, to the interests of individual persons protected by the conventional rules of promising).

One further problem with Hume's conclusion is noted by Jonathan Harrison. Treaty violations, on this view, are less serious than broken promises by individual persons because collectively the former do less harm than the latter. This is because, as noted above, individual persons seem to rely very heavily on the promising social convention whilst states could survive, albeit in an impoverished manner, without interacting with 
one another at all. But a breach of an individual treaty may be more harmful, in any one instance, than the breach of a given promise amongst individual persons (Harrison 1981, 232 - 233). It seems far more serious for a state to violate a nuclear disarmament treaty, for example, than it does for Hume to break his promise to count the blades of grass on Smith's lawn. The interests at stake are much more serious. This is so notwithstanding the fact that Hume and Smith would, Hume thinks, be more seriously harmed than any state if they did not have available a social convention of promising.

That nuclear disarmament is more serious than counting blades of grass is, I take it, not in serious dispute. We must be careful, however, not to confuse the seriousness of the content of each promise, what the promise is about, with the seriousness of the promise itself. Nuclear disarmament is more serious than counting blades of grass irrespective of any promise made. If all parties to a nuclear disarmament treaty violate that treaty by not disarming then the status quo is maintained. This is a bad state of affairs, and worse than one in which blades of grass go uncounted, but it is not worse because a treaty has been violated.

Now, of course, one party to a nuclear disarmament treaty (A) might disarm, as required by the treaty, whilst the other party (B) does not. In this case the expectations of A have been disappointed and this, I suggested, is another kind of wrong that can be done by breaking a promise. A strong interest in not having one's expectations disappointed is at stake in the example of the nuclear disarmament treaty but it is not at stake in Hume's promise to count the blades of grass on Smith's lawn. This suggests that although Hume may be correct to say that it is not as important for states to have rules of promising as it is for individual persons to have such rules, given that there is a social convention of 
promising in play any single promise, whether by a state or an individual, may generate expectations that it would be wrong to disappoint.

By analogy some of the social conventions of good manners of Regency England, as detailed in the novels of Jane Austen, may be thought of as relatively unimportant. After all, we do not think it a matter of duty for a son to visit his father's new bride immediately, still less would we think a failure to do so a moral failing, but this is exactly how George Knightley sees Frank Churchill's (in)actions in Emma (Austen 1992, 141). It is not "utterly impossible for human nature ever to subsist" without such rules. It is not that important that there be such rules and, from this perspective, $21^{\text {st }}$ century readers may attach little moral blame to Frank Churchill's behaviour. However, as George Knightley's judgment makes clear, for those whose social conventions they are, such conventions are taken very seriously. From this perspective Frank Churchill's father would have reasonably expected an immediate visit from his son. Given that the social convention operates important interests are generated. The interests of the characters in Jane Austen's novels are not completely independent of the social conventions they live by. ${ }^{101}$

\footnotetext{
101 Of course, as with the social conventions of duelling, mentioned earlier, there may be good reasons to reject the social convention in question and for Frank Churchill to ignore it, despite what George Knightley thinks. A rather more critical eye on the conventions at play in Emma is taken by George Knightley's brother, John, a character who inhabits the world of both polite society Highbury and life outside of that world. And, of course, Emma is, in part, about coming to see that the social conventions are not as important as the titular character at first believes. So, our judgment of Frank Churchill's behaviour should, I think, be complex. It depends upon the purpose of the social convention, the importance of the interests protected and promoted by the social convention, how well the social convention achieves its purpose, and also the expectations generated as a result of widespread acceptance of the social convention. One thing is worth noting. The social convention in question is not a deep one, as I suggested
} 
Likewise, that states could survive without a social convention of promising whilst individual persons could not is, from one perspective, reason to think that promise breaking contrary to the rules of the social convention is a more serious matter in the latter than the former case. However, given that states do have the same social convention they can use it to generate expectations that, as in the case of the nuclear disarmament treaty, constitute a significant interest in seeing the treaty complied with. Of course, as with promises amongst individual persons they can also be used to realise trivial ends. This is just a feature of promising. Promises can be used to generate reasons for action even in cases where there were no important prior reasons to act. The important point is that the social convention can be used to generate a strong interest in seeing the promise kept. Hume is correct to say that it is not enough to look at some set of conventional rules and assume that they are equally important to all agents. But we must also look at the particular expectations generated in each instance by the use of those rules and it is these that Hume seems to ignore in T 3.2.11. It is this fact, I think, that generates the sense amongst most commentators that Hume is too soft on international immorality.

\section{The maxim and the world}

\section{8a. The practice of the world}

All of this has been quite abstract. In principle, I suggested, there is some difference between states and individual persons insofar as the interest in having a social convention of promising at all is not as important for the former as the latter. It is this, I suggested, that explains Hume's endorsement of the shocking maxim. But also in

promising is, although it may be one possible way, amongst many others, of achieving morally worthwhile ends such as showing respect to the interests of others, including one's parents. 
principle each individual treaty may generate an important interest in seeing that treaty complied with just as any individual promise by an individual person may do. On the other hand promises, by states and individual persons, can be made that do not generate any important interests in seeing the promise kept.

Now, Hume is not just interested in theoretical claims. His appeal to the authority of "practice of all ages" is not accidental. I do not want to suggest that Hume is uncritical of the "practice of all ages", accepting that whatever it is that princes do is, for that reason, correct. I argued above, in response to Cohen, that there is no reason to think that Hume is committed to such a view. Instead I simply want to note that Hume may well recognize that in theory a treaty could generate important interests in seeing the treaty kept but that, in the actual practice of the world, they do not tend to do so, or, at least, do so to a lesser extent than do most promises amongst individual persons.

\section{8b. The interest in having a social convention at all}

Take, for example, the interest in having a social convention of promising at all. Hume's claim is that states could survive without the social convention at all. Individual persons could not, or, at least, would struggle far more to do so. This is presumably because states, and the citizens of states, would be able to survive even in the absence of treaties with foreign states. Certainly in the $18^{\text {th }}$ century the state, for most individual citizens, would have been distant and barely noticeable in their day-to-day lives and interactions between states more remote still. Hume notes that states, and their citizens, "flourish" through peaceful international interactions, especially those relating to trade. Indeed, he exhorts the "sovereigns and ministers" of Europe to "adopt...enlarged and benevolent sentiments towards each other" (Hume 1987a, 331). It is in this sense that the intercourse of these states would be "advantageous" (T 3.2.11, 569). But although the loss of such 
intercourse would be in many ways regrettable, the consequences of, say, Great Britain, cutting off all foreign commerce would not be as devastating to individual citizens as would be the loss of the ability to make promises with one another. This I suspect was true of the $18^{\text {th }}$ century. Is it still true today?

One interesting feature of Hume's argument is that, if he is correct, it is possible for the rules of a social convention to become more or less important to agents over time. Many states now stand in various close relationships, many governed by treaty, with one another, especially in the economic sphere. Take Europe. When one state, like Greece, threatens to default on its debt this has large-scale effects upon other European countries and, ultimately, on states globally. And this also impacts the lives of ordinary citizens of states to a far greater extent than, say, any financial policies and difficulties faced by Great Britain in the $18^{\text {th }}$ century. Treaty making can become, and probably has become, far more central to the interactions of states and the lives of the citizens of those states over time.

Hume is sensitive, in the Second Enquiry, to the difference that increasingly strong and concrete ties between states can make to the moral obligations of states. He notes, as a part of his discussion of morality in international affairs, that "[i]n a confederated commonwealth, such as...the Swiss Cantons and United Provinces...the conditions of union have a peculiar sacredness and authority, and a violation of them would be regarded as no less, or even as more criminal, than any private injury" (EPM 4, 206). The reason for this is that the Swiss Cantons and United Provinces, and indirectly their citizens, rely upon each other, and the social conventions that regulate their interactions, very heavily. The importance of a social convention, and the interests that the social convention protects and promotes, will depend in part upon the nature of the 
relationship between the states involved. ${ }^{102}$ In this respect at least states can become more like individual persons over time.

\section{8c. The interest in having expectations fulfilled}

What about the expectation interests that states have in having their treaty partners comply with their treaties? For example, do states typically rely less upon other states to comply with treaties than do individual persons upon promises? I suggested, above, that the expectations of a state will depend, in part, upon the importance to them of that treaty being complied with. So, for the state that has already kept its side of a bargain by disarming its nuclear stockpiles, there is going to be a much more significant level of reliance upon the other parties to the treaty reciprocating in kind than, say, upon reciprocal compliance with a treaty requiring two states to exchange materials on tourist information from their respective National Tourist Boards. The question is, however, whether states will tend to rely less heavily upon their treaties, relative to the substance of those treaties, than individual persons do upon their promises.

One reason that states would have to rely less heavily upon their treaty partners complying with a treaty would be if there was little expectation that their treaty partners would actually comply. If two states enter into a nuclear disarmament treaty and neither

\footnotetext{
102 Russell Hardin argues that as states enter into increasingly "thick and manifold" interactions with one another, becoming "more like persons", they will turn away from treaties and look, increasingly, to “institutional arrangements that transcend national governments" (Hardin 2007, 131). Agreements between Hume's Swiss Cantons, for example, are probably best not seen as treaties, on this view, because the different Cantons have given up (or never had) too much of their independent statehood. I am not sure that we can draw a very clear distinction between treaties and, say, articles of confederation. Both, in any case, seem to be instances of promises more generally.
} 
expects the other side to keep their side of the bargain, it is unlikely that either will place itself in the vulnerable position I mentioned above of having unilaterally complied with the treaty. So, Russell Hardin, in support of Hume, notes that whereas the practice of treaty violation is widely known, the same is not true of promises between individual persons. If it were true of promises between individual persons, promises between individuals would be more like treaties between states. No-one would place a great deal of faith, and reliance, in them (Hardin 2007, 130).

The problem with Hardin's argument is that it does not appear to fit Hume's own view of the matter nor, more importantly, the practice of the world. In the first place, and as I have already noted in response to Cohen, Hume does think that states are generally “engage[d]...to perform their part" (T 3.2.11, 568). Secondly, and supporting Hume's claim, treaty violation is actually apparently fairly rare (Chayes and Chayes 1995, $4-9$ ). There is little reason to think that states do not rely upon their treaties as individual persons rely upon their promises because violation is more common in the former than the latter case. So although it may well be true that states would rely upon individual treaties less heavily than individuals rely upon individual promises if the former were much more likely to be violated than the latter, there does not seem much reason to believe that this is the case.

Much more plausible is the claim that states are generally engaged in a wide ranging set of activities at both domestic and international levels. So, a state such as New Zealand may enter into a bilateral free-trade treaty with another state such as China. It may do this in order to support parts of the New Zealand economy, say those related to the production and sale of dairy products. In addition to the free-trade agreement New Zealand is likely to be engaged in a number of other activities that also support the dairy 
industry. In the international sphere it may pursue other bilateral agreements. It may also pursue domestic policies that support the dairy industry in the form of tax incentives, pursuing a monetary policy that supports increased exports, and so on. The success or failure of these policies will not affect the success or failure of the bilateral treaty with China. If the goal is to support the dairy industry, New Zealand, as would any other state, will typically have a number of ventures in place that contribute to realising that end (Guzman 2008, 122 - 124).

Of course, individual persons can pursue their various goals in a variety of ways. In particular, investors in stock markets, seeking to maximize their profits, will typically seek to diversify their risks by purchasing a range of stocks. They will not usually rely entirely upon any one stock option succeeding or failing. Nevertheless, it is plausible to suggest that states, as large, complex organizations, often backed by significant resources, are in a better position than individual persons to pursue their goals, whatever they are, through a wide variety of projects, of which the treaty is just one part. If this is correct, then, even if states generally do comply with treaties, and even though some treaties between states are more important than some promises between individual persons, for any individual treaty between states the level of reliance upon that treaty being kept will be less than the reliance placed by individuals upon a comparable promise.

There are three caveats to this argument however. Firstly, of course, I do not pretend to have established definitively that states are able to diversify their means of achieving their ends in a manner significantly different to individual persons although, as I note, there are reasons to think that this is correct.

Secondly, as I noted with respect to the argument concerning how heavily states rely upon having a social convention of promising, rather than how heavily they rely upon any 
individual promise, the situation is subject to change over time. In particular, as states become increasingly interdependent, the ability of states to realise their domestic policy goals will likely depend more and more heavily upon international cooperation and this will include treaty compliance. It is already the case that certain treaty relations, for example the GATS treaty, significantly constrain the independent pursuit of economic goals by any one state.

Finally, some states rely upon treaties more heavily than do others. Some states, in particular some in the developing world, are formally independent of other states but significantly materially dependent upon other states, and international creditors, for their continued welfare (and the welfare of their citizens). Joseph Ellin complains that Hume does not pay sufficient attention to such states, which Ellin calls "high-risk" states, and this is a reasonable complaint to make (Ellin 1988, 146 - 148). Particular states, it may turn out, will rely more heavily upon promises being kept than do individual persons. ${ }^{103}$

\section{Conclusion}

Hume's discussion and endorsement of the shocking maxim have not met with much support from philosophers. Some, such as Marshall Cohen, reject it is as immoral. Others, whilst more sympathetic to Hume, suggest that Hume's theory of justice (and promising) must be to blame for the unacceptable conclusion that he reaches.

\footnotetext{
${ }^{103}$ As I note in chapter 3, individual persons and sub-state groups can also come to rely heavily on treaty compliance.
} 
I have tried to present the most plausible reading of Hume's argument. In order to do so, I have rejected Cohen's criticisms of Hume's theory. There is room for non-conventional moral judgment in Hume's theory and there is room for non-conventional moral judgment of particular social conventions too. This includes criticism of certain aspects of the treaty making convention. The defender of Treaty as Humean Promise need not be committed to the claim that we must simply acquiesce in whatever form a social convention has taken (whether Hume himself does or does not).

By analogy with the social convention of text-message checking, I argued that it is plausible to claim that the importance of a set of rules will vary depending upon the importance of interests that those rules seek to protect and enhance. The importance of these interests, in turn, will vary depending upon the agents actually covered by those rules. The moral wrong of violating such rules will plausibly depend upon this, as Hume suggests.

Now, Hume seems to have in mind the interest that states have in having rules of promising in the first place. Counterfactually, thinks Hume, they could survive far better than could individual persons without such rules. However plausible this is it does seem to ignore the interests that a state may have in seeing a particular treaty complied with, given that the treaty has been made. That is, Hume does not seem to consider the expectation interests that states may have in a given treaty.

Finally, I turned to look at whether it is plausible in the 'practice of the world', as Hume puts it, to say that states have less interest in seeing promises kept than do individual persons. I suggested that Hume may well be correct to say that states could survive without promises than could individual persons. However, this is subject to change over time and depends upon the particular relationships between states. I also suggested that 
it may even be correct to say that states rely less than do individual persons on any individual promise being kept. I pointed to the diversity of policies typically pursued by states to achieve their goals. Again, however, this is subject to change over time and is surely truer of some states than others.

I have suggested, then, that if there is a problem with Hume's endorsement of the shocking maxim it does not lie with his conventionalist theory of promising (or justice more generally). If there is a problem, as most commentators think that there is, I have suggested that it lies in the empirical claims that Hume's argument seems to presuppose. If this is correct then it is, I think, the sort of problem that Hume the empiricist would be pleased to own. 



\section{Chapter 7: Political Realism}

In previous chapters I have set out the view that I have called 'Treaty as Humean Promise'. I have also looked at Hume's own application of the theory. In chapters 7 and 8 I change focus somewhat. In these chapters I look at a view that is sometimes labelled 'political realism'. It is a view that claims that moral constraints in international affairs (if not more generally) are irrelevant unless it is prudent to observe them. Treaties, on this view, should be kept insofar as doing so is in the 'national interest' but should, equally, be violated whenever doing so is in the national interest. 'Treaty as Humean Promise' may suggest that occasions when violation is in order are rarer than may, at first glance, be supposed but that, ultimately, it is self-interest (or the national interest) that is the central consideration. As we shall see in this chapter, this is what the adherent of political realism says too.

\section{Realism, rationality, and the national interest}

I take as my starting point for the realist account of treaties a claim made by Niccolo Machiavelli. Talking about the promises made by rulers, or 'Princes', Machiavelli makes the following claim. According to Machiavelli, a "prudent ruler cannot keep his word, nor should he, where such fidelity would damage him, and when the reasons that made him promise are no longer relevant" (Machiavelli 1988, chap. 18). Although this claim is open to a number of interpretations these shall not concern me here. I shall assume that Machiavelli is making a realist claim about the status of treaty obligations. What, then, is this realist claim about treaties? 
The realist position can be put roughly as follows. A prudent ruler of a state should adhere to the terms of a treaty wherever it is advantageous for that state that she does so. She should violate the treaty wherever keeping the treaty would be disadvantageous to the state of which she is the ruler. But what does it mean for treaty-keeping to be disadvantageous? An act, I shall assume following David Gauthier, is disadvantageous to an agent when it is an act that, in the context of performance, would be less advantageous to the agent, given what the agent wants to achieve, than some other act open to that agent in the circumstances (Gauthier 1970,168). They are acts such that the agent can say that it would better for the agent not to perform that act. But there are different ways in which an act can be 'better' for an agent.

One way of understanding what it means for one act to be better than another for an agent is to say something like the following. I act in a way that is disadvantageous to me if, given two feasible choices, $x$ and $y$, and when I prefer doing $x$ to $y$, I nevertheless choose to do $y$. There would be some action open to me, in the circumstances, which would be better for me insofar as it realises my preference for $x$ over $y$. We might say that it is in my interest to avoid doing $y$ and to do $x$ instead. So, for example, I might face a choice between spending \$5 on chocolate ice-cream and spending $\$ 5$ on peach sorbet. I prefer chocolate ice-cream to peach sorbet but, for some reason, choose the sorbet. I could have done better for myself by choosing contrary to the way in which I did choose. I acted in a way that is disadvantageous to me, by my own lights, even if I like peach sorbet and prefer it to having nothing at all.

To act in this way is to fail to act rationally, according to a common way of thinking about rationality. An agent is rational, on this account, if her preference set is formally consistent and, importantly, if she chooses based upon those preferences. The concept of 
rationality used here is purely instrumental. It is the concept of rationality adopted by most realist authors. Many realists take the rationality of states to be central to realist accounts of international relations. ${ }^{104}$ Andrew Kydd, for example, claims that it is the "fundamental assumption behind realism" (Kydd 1997, 120). Furthermore states are assumed to seek to further the so-called 'national interest'. 105 This means that states act rationally to pursue self-interested ends. The analogy to be drawn is with the individual agent, often employed in economics, who single-mindedly seeks to maximize her profits (Waltz 1979, 89; 1996, 55). However, states do not typically aim to maximize monetary profits but rather their geo-political security. Rationality, moreover, is a normative notion. Insofar as they are agents, states, or those who act on their behalf, ought to be rational. It would be wrongheaded, mistaken, or foolish, but not necessarily moral or immoral, to fail to act rationally.

But not every preference that an agent has is better for that agent simply because it is a preference that she happens to have. Likewise, not every conceivable preference will be in the national interest simply because it is preferred. For example, for the USA, 'doing $x^{\prime}$ might be 'donate $\$ 1$ bn to struggling Haitian farmers' whilst 'doing $y$ ' might be 'flood the Haitian market with cheap American agricultural products in order to support the American economy'. The President of the USA might prefer $x$ to $y$, and do $x$ (because he prefers it to $y$ ) but also act in a way that is disadvantageous to the USA. 'Doing $y^{\prime}$ would have been better for the USA. Nevertheless, according to the instrumental conception of

\footnotetext{
${ }^{104}$ See, for example, Morgenthau 1962a, 278; Waltz 1979, 117; Mearsheimer 1994/5, 10; Labs 1997, 7; Kydd 1997, 120.
}

105 See, for example, Osgood and Tucker 1967, 304; Schwarzenberger 1951, 13. 
rationality it would be irrational for the President of the USA to act in the national interest.

Realists who admit that states can have preferences which are contrary to the national interest nevertheless think that they ought not to have such preferences. Kenneth Waltz, for example, admits that states are "free to do any fool thing that they care to" (Waltz 1997, 915). Waltz's language makes clear what he thinks of such states. They behave foolishly, and have foolish or otherwise mistaken preferences, if they fail to act in their own national interest. The reason which is often given for why such preferences are foolish is that international affairs lack an effective government or police force to enforce common rules and standards of behaviour. States must look out for their own interests. John Mearsheimer, for example, claims that "in the final analysis, the system forces states to behave according to the dictates of realism, or risk destruction" (Mearsheimer 1995, 91).

Some realist authors simply claim that preferences which are altruistic and otherregarding are irrational. For example, part of what it means for a government to be rational, according to Felix Oppenheim, is for that government to act in ways that realize the national interest. For Oppenheim the national interest cannot be simply reduced to the aggregated preferences of the citizens of the state or of the ruler (or any other group within the state). Oppenheim claims that saying that a ruler acts in the national interest means that she pursues "the state's territorial integrity, political independence, military security, and the population's collective economic well-being" (Oppenheim 2002, 4).106

\footnotetext{
106 Oppenheim calls these 'primary goods' in the Rawlsian sense. They are, according to Oppenheim, what states need whatever else they want to achieve and whatever else they value. However, Oppenheim does not always seem to be talking about the national interest being primary goods for states per se. He gives
} 
These goods are pursued, according to Oppenheim, because they are supposedly goods that any state would seek to obtain whatever else they wanted. They are, so to speak, primary goods for states (ibid).

There is a great deal more that can, and has, been said on the subject of rationality and the national interest. For the sake of simplicity I shall take the realist to be saying something like the following. A ruler who acts in the national interest prefers choice $x$ to choice $y$ iff she believes that $x$ is strictly better for the state of which she is ruler than is $y$. Rational rulers acting in the national interest always prefer to act in accordance with what they believe is better for the state rather than what they believe is worse (see Hausman and McPherson 2006, 64). This, according to the realist, is how they should act. It does not follow, of course, that the ruler in fact routinely prefers what is better for the state. Indeed, some realist authors complain that some forms of government, such as democracy with its emphasis on "the emotional preferences...of public opinion", often blind rulers to what is in the national interest (Morgenthau 1962b, 106). We could make a further assumption that the ruler of the state possesses full knowledge. If a ruler is rational, seeks to act in the national interest, and has full knowledge, then she will prefer $x$ to $y$ iff $x$ is in fact better for the state of which she is ruler than $y .{ }^{107}$ This, of course, is an

the example of a Dictator who pursues these aims to stay in power (Oppenheim 2002, 5). But these are the interests of a particular government. Why think that this is also the 'national interest'?

${ }^{107}$ In chapter 8 I claim that the assumption of such 'full knowledge' is implausible in international affairs. Without it, however, I suggest that the political realist should endorse, and follow on each occasion, the rule that treaties must be kept (subject to certain qualifying conditions). 
idealisation. But it is useful if only to remind ourselves that what the ruler judges to be in the national interest is not, simply and for that reason, in the national interest.

Treaties sometimes call on states to perform actions which the ruler of that state, acting in the national interest, does not believe serves the national interest. The act required by such a treaty is such that the ruler of the state in question can say that it would be better for the state not to perform the act. If she possesses full knowledge, or just happens to be correct, then what she says will also be true. There will be some action open to the state in the circumstances which would be more advantageous to that state than complying with the treaty. It really would be better for the state not to comply with the treaty in question.

Rather than engage further in discussion about this conception of rationality and the national interest I shall move on to some illustrative examples which, I hope, capture the realist position in an intuitively plausible manner. Later I shall relax this conception of the national interest to include rationally acting in ways that a ruler believes are strictly better for another state (or for the citizens of that state). I suggest that this makes less difference to the realist argument regarding treaty compliance than one might think. Less rests, as a result, on defining what, precisely, is in the 'national interest' than might, at first sight, appear.

Let us turn, then, to the examples. In each case the realist position is that the ruler of a state should not comply with a treaty where doing so is disadvantageous to the state in the sense outlined above. 


\section{Harmony and coordination}

In a moment I am going to look at a couple of cases in which the prudent pursuit of the national interest appears to require treaty violation. However these two cases might give the impression that states acting as the realist says they ought to act will rarely, if ever, cooperate by means of treaty to get things done. This may be true of some treaties. It is not true of all of them. Some agreements are such that, once agreement has been achieved, it is not in the national interest of any state to violate them.

\section{$\underline{\text { 2a. Identical Interests }}$}

In some cases the national interest of two, or more, different states might be entirely aligned. The self-interested behaviour of Australia and New Zealand might simply converge on some issue important to both. Fernando Teson gives an example of two states where each state allows its citizens freedom of information and where, as a result, citizens in the other state receive newspapers, magazines, and books which are also freely allowed in the other state (Teson 1998, 81 - 2). This, for example, is the case with Australia and New Zealand. This, Teson claims, is advantageous for both states. Teson suggests that, in this case, there is no need for a treaty at all because there is already no purpose to be served in violating the agreement (ibid, 82). Still, Australia and New Zealand might want to enter into a treaty recognizing this arrangement because they understand that circumstances might alter such that one party comes to believe, perhaps erroneously, that it would be better to violate the agreement. Or they may simply wish to 
signal to one another a close political relationship or signal to other states the value they attach to freedom of information. ${ }^{108}$

\section{$\underline{2 b .}$ Coordination of standard weights and measures}

Two (or more) states may not have identical interests but nevertheless have an interest in coordinating their actions with one another. That is, both states have a common interest in arriving at some common coordination point. The main obstacle they face is making sure that they aim for the same coordination point in cases where there are at least two options (Lewis 1969, 5 -24). So, for example, two or more states might realise that they will do better by adopting a system of weights and measures common to all than they would do otherwise. ${ }^{109}$ One way of ensuring that these countries adopt standard weights and measures is to negotiate a treaty. Treaty negotiation might be important to ensure that they coordinate on the same weights and measures and also in instances where each state would prefer, most of all, that the other state adopts their own standards. What is important about the treaty, however, is that whichever standard of weights and measures is settled upon, once the states have coordinated with one another no state would do better by unilaterally violating the treaty and returning to the status quo ante. In such cases no-one will benefit from unilateral treaty violation. ${ }^{110}$ It is in the

108 Plenty of states, after all, seem to have come to the conclusion that freedom of information is not in the national interest.

${ }^{109}$ I have in mind the International Bureau of Weights and Measures (BIPM) which was created, by treaty, in 1875 and currently has 51 signatories.

110 In game theoretical language the coordination point is a 'Nash equilibrium'. No party to the treaty can improve its payoff by unilaterally violating the treaty. Some realist authors suggest that even such 
national interest of all states to comply with the treaty. The same is not always true of the treaties to which I turn now.

\section{Intermediate-Range Nuclear Forces Treaty (INF Treaty), 1987}

\section{"I think the inherent right of the government to lie to save itself when faced with $\underline{\text { nuclear disaster is basic }}^{\prime 111}$}

The INF Treaty was a treaty between the USA and the USSR which had the aim of curtailing the nuclear arms race that had developed between the two superpowers. Given the nuclear capabilities possessed by both the USA and USSR each recognized that the outbreak of military hostilities between the two states would most likely be completely, and mutually, disastrous. The USA and USSR thus agreed that it would in the nationalinterest of each to mutually disarm. The INF Treaty would not leave one side weaker than the other but it would help to avoid the undesirable outcome of catastrophic nuclear war. The INF Treaty would be advantageous to both the USA and USSR if both acted as the treaty required. However, it would not be to the advantage of the USA to act, and hence disarm, unilaterally. It would also, of course, not be to the advantage of the USSR to act unilaterally. Unilateral action would be the worst possible outcome to the state that so

coordination treaties are very difficult to accomplish and, when they are accomplished, unstable. This is because states seek relative gains over their treaty partners. They are not simply concerned with how much they get from a treaty but how much more they get from the treaty than their rival gets.

${ }^{111}$ Arthur Sylvester, Deputy Assistant Director of Defense for Public Affairs under US President Kennedy. He was talking about the Cuban Missile Crisis of 1962. 
acted. One of the reasons for entering into the INF Treaty in the first place was for each to avoid just such an outcome whilst ensuring a reduction in nuclear capabilities. Being the only superpower left standing however, by virtue of nuclear capabilities, would be the best outcome possible.

US President Ronald Reagan and his Soviet counterpart Mikhail Gorbachev had to decide whether or not to comply with the treaty and disarm, or violate the treaty and not disarm. Imagine that you are Gorbachev. You do not know whether or not the USA will comply with or violate the treaty. Do you disarm? You might choose to disarm, of course, if Soviet disarmament would, of itself, be advantageous to the USSR. But this is not the case. You do not expect the USSR to benefit because it disarms. You expect to benefit, instead, from the disarmament of the USA (Gauthier 1970, 170 - 171).

If the USSR violates the treaty whilst the USA disarms then Soviet violation of the treaty would be advantageous to the USSR. If, on the other hand, the USSR violates the treaty and the USA violates the treaty then the USSR has successfully avoided the worst outcome of all from the Soviet perspective: unilateral disarmament. Either way, treaty compliance seems to be genuinely disadvantageous in the following sense. There is some other action available in the circumstances, namely violation of the treaty, which is better for the USSR irrespective of how the USA acts. As the same goes for the USA, treaty violation looks to be in the immediate national interest of both parties. ${ }^{112}$ But this represents something of

\footnotetext{
112 In game theoretical terms the full strategic structure of the treaty interaction is known by both parties. This means that both parties are aware that the other party is rational, of the possible actions open to each, of the possible outcomes of any possible interaction, and of the value, expressed in terms of the national interest, which each party places on each possible outcome of the interaction. Furthermore, each party not only knows but also knows that the other party knows the strategic structure of the interaction.
} 
a dilemma. If each chooses to act in the national interest then both parties will find themselves worse off than if they had both complied with the treaty even though they had no idea what the other party intended to do (ibid, 171).

\section{“Trust, but verify"113}

Although treaty violation seems to be in the best interest of both parties this may not be so in all circumstances. I have assumed, for example, that the actions of each side are unknown to, and hence independent of, the other. So, whether the USSR disarms makes no difference to the decision of the USA to disarm. But treaty violation may not be prudent where there are effective verification procedures allowing each side to monitor compliance with the terms of the treaty. Assuming effective monitoring, if the USSR violates the treaty then, let us assume, the USA will know of the violation and adjust its own actions accordingly. As the USA does not want to disarm unilaterally, violation by the USSR would, most likely, lead to counter-violation by the USA. Unless the USSR takes action to redress this situation the purpose of the INF Treaty would be completely undermined. Given these circumstances treaty compliance, rather than violation, seems prudent (ibid, 173).

\footnotetext{
What they do not know is how the other side chooses to act. But each can work this out as we have seen. The USSR's best strategy, it seems, is to violate the treaty through fear of being successfully exploited by the USA and hope of successfully exploiting the USA. In (more) game theoretical terms, treaty violation is a strongly dominant strategy. The realist theory prescribes a course of action for every state.

113 This, apparently, was a favourite quote of President Reagan when negotiating treaties with the USSR. I focus here on the 'verify' part of the quote.
} 
If the rulers of both the USA and the USSR are prudent agents acting in the national interest then each will violate the INF Treaty wherever they can realistically get away with doing so. Perhaps there will, in fact, be no such opportunities to violate the treaty. For the realist, however, it will remain an open question whether or not the USA or USSR should violate the treaty. If they do both comply with the treaty, for whatever reason, then they will each receive the benefits of their treaty bargain, in this case mutual disarmament, even if each could have hoped to have done better. On the other hand both parties will have avoided the maintenance of the status quo ante. Sometimes, however, one side or the other would appear to do better by violating the treaty whatever the other party does.

\section{$\underline{\text { 3a. Star Wars and Changed Circumstances }}$}

Imagine, now, that both sides are complying with the INF Treaty. Both sides are benefitting from the other side disarming its nuclear stockpile. But now imagine that the following event occurs. The USA, subsequent to signing the treaty, develops an effective version of the Strategic Defense Initiative (SDI) (see ibid, 177). The SDI can effectively protect the USA from nuclear missile attack, precisely the weapons the INF Treaty is aimed at disarming.

Should the USA keep its treaty commitments now that the circumstances have altered in this way? The USA now gains little, if any, obvious benefit from Soviet disarmament. Whatever the USSR does, the USA does best, by its own lights, by not disarming. In other words, the USA would not have agreed to the INF Treaty if they had possessed the SDI at the time of treaty negotiation and so should no longer comply with it now that they do. The rational, prudent US President acting in the national interest will not comply with the 
treaty. And nor should he according to the realist. In these circumstances, as Machiavelli puts it, "the reasons that made him promise are no longer relevant". ${ }^{114}$

\section{The Kyoto Protocol, 1997}

So far I have looked at simple treaties involving just two parties. Many treaties, however, are multilateral. This simply means that there are more than two parties to the treaty. Sometimes there are hundreds. The Kyoto Protocol (1997) is an international treaty which has the aim of binding signatories to the reduction of dangerous $\mathrm{CO} 2$ (and other) emissions. The treaty came into force in May 2002 when Iceland ratified the treaty, the $55^{\text {th }}$ state to do so. At the time of writing, 191 countries have ratified the treaty. However Canada has recently renounced the treaty (December 2012) and the USA, one of the major global contributors of $\mathrm{CO} 2$, never ratified the treaty.

\section{4a. Some assumptions}

Let us imagine a slightly different, and simplified, version of the Kyoto Protocol. It is one where every single state has signed and ratified the treaty. Each state has thus committed to reduce its $\mathrm{CO} 2$ emissions by an agreed amount. The aim of the agreement, and the general reduction of $\mathrm{CO} 2$ emissions, is to avoid the effects of dangerous climate change. Let us call the avoidance of dangerous climate change 'the collective good'. The good is collective insofar as the avoidance of dangerous climate change is a good for each and every state. This collective good is non-excludable. This means that the benefits from reducing $\mathrm{CO} 2$ emissions accrue to all states, regardless of whether or not they have

\footnotetext{
${ }^{114}$ Russia, as successor to the Soviet Union, has in fact indicated that it no longer considers the INF Treaty to be in the Russian national interest although, as yet, it has done no more than indicate this (at least openly).
} 
reduced their $\mathrm{CO} 2$ emissions. Nevertheless, each and every state prefers the outcome where the collective good is provided to an alternative outcome where dangerous climate change occurs. This is why they have all signed and ratified the treaty. Unlike in the real world imagine that each state faces a binary choice. Each state can either reduce its $\mathrm{CO} 2$ emissions by the treaty-prescribed amount or it can fail to do so.

A further complication is that there are two ways in which any individual state might contribute to achieving the collective good. Firstly, each state which contributes by reducing its $\mathrm{CO} 2$ emissions might make some beneficial difference, however small, to the achievement of the collective good. Alternatively, it might be the case that an individual state's contribution may not benefit anyone except where it comes at some threshold which makes the difference between the collective good being realised or not (Pettit 1986, 367). Let us assume, for the moment, that each contribution by each state makes some beneficial difference, however small, to the achievement of the collective good.

Let us also assume the following. The collective good cannot be realised if no state reduces its $\mathrm{CO} 2$ emissions by the agreed amount. The collective good can, however, be realised when the group of all states $(\mathrm{N})$ reduce their $\mathrm{CO} 2$ emissions by the agreed amount. The collective good can also be realised, at one of many levels, by a subgroup of members of $\mathrm{N}$, where the number of states forming the subgroup of members number less than $\mathrm{N}$ but more than 1 (ibid, 367 - 368).

As with the real-world Kyoto Protocol it is costly for states to reduce their $\mathrm{CO} 2$ emissions. The benefits accruing to any individual contributor fail to cover the costs that they have to bear in contributing because the collective good cannot be attained by any contributor acting alone. This means that for each individual state the cost of reducing its $\mathrm{CO}_{2}$ emissions always exceeds the value of the amount of the collective good which its own 
actions would bring it. So, no state benefits, all things considered, just because it complies with the treaty. Each state benefits insofar as others keep the treaty. In this respect the Kyoto Protocol is like the INF Treaty.

\section{4b. Should Canada comply?}

Each state must decide whether or not to keep its treaty commitments and reduce its $\mathrm{CO} 2$ emissions by the prescribed amount. Imagine that you are the Prime Minister of Canada. Should Canada keep its treaty commitments and reduce its $\mathrm{CO} 2$ emissions?

I have assumed that each state is better off if every state keeps the treaty than if every state violates the treaty. Thus Canada is better off if every state, including Canada, keeps the treaty then it is in a situation in which every state, including Canada, violates the treaty. Moreover I have assumed that the more states keep the treaty the better the outcome to each state. Nevertheless, no matter how many other states keep the treaty and reduce their $\mathrm{CO} 2$ emissions, all else being equal ${ }^{115}$ Canada is better off violating the treaty. The more states keep the treaty, the more of the collective good is provided irrespective of whether Canada contributes. Furthermore, the costs of keeping the treaty exceed the benefits which Canada's own compliance would bring it. Worries about

115 When might not all else be equal? Well, there may be sanctions imposed by other signatories on those who refuse to comply with the Protocol. The efficacy of such sanctions assumes that other states are willing to bear the costs of punishing Canada (and that they are aware of Canada's violation). The willingness to bear the costs of applying sanctions cannot be simply assumed. Punishment of violation is itself what I have called a collective good. Just as Canada may seek to free ride on the Kyoto Protocol so potential punishers might prefer that some other state take on the unpleasant job of applying sanctions to Canada. Canada might think it worth the risk of no-one being willing to do this. (Brennan and Pettit 2004, $270-274)$ 
contributing when the collective good is not provided and the prospect of not contributing when it is make it prudent for Canada to violate the treaty (ibid, 368).

\section{4c. 'Lumpy' climate change}

I have assumed, so far, that all contributions make a beneficial difference to the provision of the collective good but that the costs to any individual contributor exceed the benefits to be had from its own contribution. But the reduction of $\mathrm{CO} 2$ emissions might not be like this. We can imagine that up to a certain number of treaty compliant states none of the collective good is produced. So, say, if just 54 states reduce their $\mathrm{CO} 2$ emissions damaging climate change will not be avoided. However, imagine that scientists have worked out that when 55 or more states reduce their $\mathrm{CO} 2$ emissions then damaging climate change can be avoided. As it happens 54 states, excluding Canada, have already reduced their CO2 emissions. Assuming, as I did, that Canada prefers the provision of the collective good to a situation in which it is not provided at all then it looks as though Canada should comply with the treaty after all.116

There are, however, still some options open to you if you want Canada to enjoy the collective good without contributing to it. One option is not to comply in the hope that some other state, wanting to reach the magic number of 55, will comply. The risk, of course, is that every other state will reason in the same way and refuse to comply, hoping

\footnotetext{
116 This may not seem like a very plausible scenario with respect to climate change. It is, however, a situation that might be faced by states that are deciding whether or not to comply with the directives of the International Whaling Commission should whale numbers reach critical levels.
} 
some other state will comply. 117 of course, you might try pre-committing Canada to not complying by announcing that Canada is going to violate the treaty whatever any other state does. ${ }^{118}$ The danger, here, however, is that other states will also pre-commit or that they will try to call Canada's bluff. There is, it seems, no straightforward piece of realist advice for the prudent ruler in these circumstances.

\section{$\underline{\text { 4d. Altruistic Canada119 }}$}

How much of the plausibility of the realist case rests upon acceptance of the idea that the ruler of a state should only ever seek to act in national interest, narrowly understood? Can we relax the realist assumption that rulers should always act in the national interest

\footnotetext{
${ }^{117}$ This kind of scenario is often called 'Chicken' in game theory. It is named after the game played in the film Rebel Without a Cause where two drivers drive their cars at one another with the first player to swerve the loser. The loser in the game in the film loses face so it is best for him if the other player swerves first. However it is second best that both swerve, next best that he swerves, and worst of all if no-one swerves at all. This is unlike the nuclear disarmament case, above, where the worst outcome for each is to 'swerve' (violate the treaty) whilst the other side keeps going. It is, however, rather like the situation faced during the Cuban Missile Crisis.
}

${ }^{118}$ Such 'threats' might be effective. Once the USA pulled out of the actual real-world Kyoto Protocol the other participants (in particular the EU) were anxious not to lose Japanese participation. (Japan supposedly having the least to gain from continued participation). Japanese emission reduction targets were reportedly reduced from 6\% to 1\% (Barrett and Stavins 2003, $371-2$ ).

${ }^{119}$ As I note earlier in this thesis, I may give the impression that I think the world divides neatly into 'good' and 'bad' states or selfish and altruistic ones. I do not mean to endorse such a position. My point is, rather, that it does not really matter much what preferences or motivations we attribute to states or their rulers, the same kinds of problems still arise regardless. 
by, for example, imagining a state with altruistic preferences and still plausibly argue that the prudent state should opportunistically violate treaties whenever it can expect to gain by its own - now altruistic- lights from doing so? There are reasons to think we can. It is enough for the realist case to assume that rational rulers aim to satisfy the preferences of the state, however calculated, whether those preferences happen to be self - or otherregarding. ${ }^{120}$ Even where the preferences of a state are not strictly better for that state, nor believed to be strictly better for the state, treaty compliance can no more be guaranteed than if we assume that the state is always self-interested.

Imagine that Canadians consider themselves to be a force for moral good in the world. ('It's the Canadian way!' ${ }^{121}$ ). Canada prefers making the world's worst-off better off than they currently are to only making Canada, and Canadians, better off. So Canada has an

${ }^{120}$ This is not quite correct. A state, like any other agent, might have a preference for keeping its commitments or, more generally, for participating in collective endeavours. If all states had these preferences then treaty making would be a straightforward, if rather uninteresting, business. One problem with such a preference is that it does not seem to distinguish between treaties which have no socially undesirable side-effects on third parties and treaties which do. For example, a coterie of grain producing states could enter into a treaty to ensure that the price of grain was kept artificially high. That is, they could form a kind of international cartel. The same temptations of treaty violation for individual gain, to sell more grain in this case, will face each state just as they did in the case of the INF Treaty. However, unlike the INF Treaty this looks, from the perspective of everyone else, to be a desirable outcome.

${ }^{121}$ It might seem as though the realist pursuit of the national interest should rule out such appeals. Not all realists agree. George Kennan, for example, thinks that the USA can conform to moral standards but only when "they are founded on traditional American principles of justice and propriety" (Kennan 1985/6, 208). 
active program whereby it provides mosquito-nets to people in states where malaria is prevalent. This program, let us assume, is having demonstrable effects in reducing malarial deaths.

Should Canada comply with the Kyoto Protocol? It is costly to do so and these costs could be spent instead on the Canadian anti-malaria program. In other words, compliance with the Kyoto Protocol (as with many other treaties) imposes opportunity costs upon those complying. Resources which could be spent on mosquito nets (or anything else) are instead spent on ensuring compliance with the treaty. Plus, it is still the case that Canadian compliance alone will not make the difference between success and failure to realise the collective good. In other words, it may be just as rational for an altruistic state to violate the Kyoto Protocol as it is for the Machiavellian, realist state to do so. Treaty compliance would still be genuinely disadvantageous to Canada by its own, otherregarding, lights.

\section{Complex calculations and conditional strategies}

I have presented a realist account of treaties by reference to Machiavelli's apparently simple advice to the prudent ruler. What it requires in practice however can be quite complex. A prudent ruler acting in the national interest must calculate the costs and benefits of various courses of action and must be prepared to second guess the behaviour of other states. Sometimes it might be worth trying to get away with violating a treaty despite the existence of monitoring. Many treaties are also intended to last a long time and it is not always possible to foresee the circumstances in which treaty commitments are to operate and calculate the likely future costs of compliance or violation. Sometimes, for example, states commit to actions that fail to lead with certainty to any particular 
outcome. ${ }^{122}$ In other instances, as with the example of CO2 emissions, a state can comply with (or violate) a treaty more or less. Practically speaking, the demands of calculating what is in the national interest, from the set of feasible choices, is daunting. Realism might seem to make more demands of a ruler than she could reasonably expect to fulfil.

Trying to work out the costs and benefits of treaty compliance is not only potentially complex but can also be expensive. Governments must spend resources on policy analysis and decision making. It is even possible that the prudent ruler may spend so much time, and so many resources, through the constant recalculation of advantage and disadvantage as to fail to receive the very advantages that she is after. Under normal circumstances the prudent ruler may do best to presume in favour of treaty compliance. This is sometimes taken to be an argument against the kind of realist view of treaties that I have sketched here (Chayes and Chayes 1995, 4). Sometimes to this argument is added the observation that states can expect to interact with one another, often on the same issue, an indefinite number of times. Where this is the case the rational ruler, acting in the national interest, will do that best by complying with the terms of a treaty whenever the other party complies and violating the treaty whenever they violate. In game-theoretical terms this is called adopting a strategy of Tit-for-Tat (Axelrod 1984, 31-36). This assumes that states can effectively monitor one another's actions over time and so is an iterated version of the argument I presented in section 3, above.

None of these observations is, in fact, damaging to the realist position. In many circumstances compliance with treaties is perfectly rational, prudent, and serves the

\footnotetext{
122 The ruler, here, needs to be able to identify consistent preferences, in line with the national interest, for all possible risks over each of the possible outcomes. Where probabilities are simply unknown things become more complex still.
} 
national interest. All of this can be straightforwardly accommodated by the realist. What we learn from these observations is that the rulers of states, acting in the national interest, may simply adopt the strategy that promises to best realize the national interest given the often complex circumstances, and real restrictions, of actual decision making. ${ }^{123}$ This is precisely how the realist thinks rulers of states should behave. And nothing precludes the possibility that sometimes, say when the stakes are high or the risks of being found out are low, the rational ruler, acting in the national interest, should yet still violate the state's treaty commitments. Whether a treaty should be complied with or violated remains, as it must for the realist, an open question.

\section{Treaty as Promise}

Let us compare the realist view of treaty compliance and violation with the view I have elsewhere called Treaty as Promise. In practice, we have seen, rulers acting in the national interest may in fact do best by complying with treaties. The reason that the realist ruler chooses to comply with a treaty, however, is due to her calculation of the expected payoff to the state of which she is ruler. But the ruler who complies with a treaty for these reasons is not doing so for moral reasons. This is because the rational ruler acting in the national interest never willingly acts in ways contrary to the national interest. But when an agent acts morally she is prepared to act in ways that potentially run contrary to her self-interest or the interests of the institution which she represents.

\footnotetext{
${ }^{123}$ A similar reply is sometimes made by the utilitarian faced with the objection that constant utility calculation by any agent will mean that they fail to maximize utility (Mill 1969, 225).
} 
If I act morally, on this view, then I keep my promises because it is my moral duty to do so and not because I have calculated what is advantageous to me (Teson 1998, 79). I should do this even where I would prefer not to keep my promise. Insofar as treaties are kinds of promises, a moral ruler should comply with the treaty because it is her moral duty to do so and irrespective of calculations of the national interest or, indeed, the satisfaction of any other preferences. She complies with the treaty because it is the right thing to do. Other alternatives for action are, in effect, overridden. Treaty as Promise, then, seems to be much more straightforward in practice than the realist view.

But why is treaty-keeping the right thing to do, morally speaking? One way of answering this question is to say that there is a moral rule that requires treaty-keeping and that this renders treaty violation morally wrongful. In the case of treaties this moral rule is sometimes identified with what is generally thought to be a well-accepted customary rule of international behaviour; pacta sunt servanda ('pacts must be kept') (ibid, 89).124 Whether or not pacta sunt servanda is a customary rule, however, is neither here nor there on this account. What matters is that it is a moral rule, that it is morally wrong to violate it. This moral rule can be justified by appeal to certain moral intuitions we have about promising and the wrong involved in knowingly misleading others. All things being equal it is morally the right thing to do to keep one's word. It is also morally wrong to knowingly mislead others by first getting them to form expectations regarding one's future

\footnotetext{
${ }^{124}$ We can compare the moralised sense of pacta sunt servanda with the sense that the realist might give it. For the realist such a rule is best thought of as a 'rule of thumb', as a way that the rational ruler acting in the national interest can, in normal circumstances, expect to best realise the national interest.
} 
behaviour which one later disappoints. ${ }^{125}$ One way of doing the latter is by making and then breaking a promise. ${ }^{126}$ The analogous act in international affairs is a state entering into, and then violating, a treaty. Let us look, briefly, at what the proponent of such a view of treaties would say that rulers should do, and why, in two of the cases discussed above.

${ }^{125}$ This view is also adopted by Treaty as Humean Promise (see chapter 3). The political realist, it seems, can accept Treaty as Humean Promise's claim that treaties create self-interested reasons to comply with a treaty (which may, or may, not be sufficient to counterbalance the reasons the state has to violate the treaty). The political realist will, however, deny that the moral reasons to comply with the treaty, also identified by Treaty as Humean Promise, are relevant to a state.

126 It might be thought that the wrong of misleading others entirely accounts for the wrong of failing to keep one's word. Some philosophers think this (Mason 2005; Dworkin 2011, 308 -11) but many others think that there must be some additional wrong involved in breaking a promise because we seem to create a new obligation. I do not deal with this question here. 


\section{6a. The INF Treaty}

Firstly let us look at the nuclear disarmament treaty discussed in Section 2, above. Remember that this treaty required the USA and USSR to dismantle their nuclear arsenals in order to avoid catastrophic nuclear war whilst maintaining the balance of power between two historic, and mutually distrustful, enemies. I suggested that the realist would say that each side should violate the treaty wherever its actions are independent of the actions of the other side but comply where each side can monitor the actions of the other and adjust its own behaviour accordingly.

According to Treaty as Promise, having entered into the INF Treaty both the USA and USSR create a moral obligation to disarm. This moral obligation is created by virtue of each party to the treaty making a promise to the other party. The USA and USSR should comply with the treaty when compliance is being monitored. But the USA and USSR should not comply with the treaty simply because their actions are being monitored. They ought to comply with the treaty even if treaty compliance is not being monitored. And they should comply with the treaty because they each have a moral duty to do so. They are each obligated to comply with the treaty even where there is some alternative action available to them in the circumstances which would be more advantageous from their own perspective.

What about our alternative case where the USA has developed an effective Strategic Defense Initiative and where, on the face of it, they do better by violating the treaty than by complying whatever the USSR does? Compliance with the treaty is now costly to the USA because circumstances have altered. But Treaty as Promise holds that states must honour their treaties even when doing so runs contrary to the national interest. Even 
when the reasons that led the USA to enter into the treaty no longer apply, the moral obligation to comply with the treaty persists.

\section{6b. The Kyoto Protocol}

The same reasoning applies to the example of Canada deciding whether or not to violate its treaty commitments under the Kyoto Protocol. It makes no difference how many signatories the treaty in question has. Canada should comply with the treaty for the same reason the USA and USSR should comply with the INF Treaty. Each party to the treaty made a promise to the other parties to the treaty that they would reduce their $\mathrm{CO} 2$ emissions. Again, if all comply with the treaty, including Canada, each does better than they would do if all violated the treaty. But, again, this is not central to the justification of Canada's treaty obligations which would continue to obligate even if this were not the case for any one party.

Moral deliberation and action are supposed to constrain the choices open to an agent rather than simply being reflected in the preference set from which she makes her choices (ibid, 79 - 80). We have seen how this is supposed to work with respect to rulers constraining their pursuit of the national interest by adhering to the moral norm that promises must be kept. Even where treaty violation is advantageous to the state it ought not to be done. But what about the case where Canada violates the Kyoto Protocol in order to act altruistically? Treaty violation by Canada, I assumed, would not make the difference between the success and failure of the treaty to realise the collective good. However, complying with the treaty would impose opportunity costs upon Canada which could be alternatively spent pursuing its anti-malaria policy overseas.

What Treaty as Promise claims is simply that moral commitments, the duty to keep a promise for example, will sometimes conflict with an agent's preferences. It will 
sometimes conflict with those preferences whether they happen to be self-interested or altruistic. Insofar as Canada simply prefers acting altruistically to any other action, the mere fact that it has this preference is neither here nor there when it comes to determining what Canada ought to do morally speaking. Canada has a moral duty to comply with the Kyoto Protocol. Canada has this moral duty because it created this duty by making a promise to all of the other signatories to the treaty. Moral considerations constrain preferences.

\section{The conflicted ruler?}

Sometimes consideration of the national interest will require treaty violation whilst the requirements of morality will require treaty compliance. Realism, as we have seen, tells the ruler that she ought to aim at the national interest of the state of which she is ruler. Treaty as Promise tells the ruler that she ought to comply with treaties because there is a general moral duty to do so. The ruler of a state is faced with two theoretically contradictory normative requirements. Either the ruler should act so as to further the national interest, violating treaties where this achieves this end, or she should comply

with treaties because she has a moral duty to do so irrespective of the costs to the national interest of doing so. In at least some instances, then, the ruler, or other decision maker, in a state will face a conflict between two apparently mutually inconsistent demands of practical reason.

But is the gap between the realist view and Treaty as Promise really so wide? Not necessarily. In the next chapter I turn to look at realism as a consequentialist theory. Like other consequentialist theories, notably utilitarianism, we can distinguish between 'act' and 'rule' variants of realism. The view I call rule realism, I suggest, requires that rulers 
of states comply with their treaty commitments even when they might expect to better serve the national interest by violating those commitments. Moreover I argue that the realist should be a rule realist, at least about treaties. Although some differences remain, for practical purposes the ruler of a state will not be as conflicted as may, at first, appear. I turn to discuss act and rule variants of realism in the next chapter. 



\section{Chapter 8: Act and Rule Realism}

In the previous chapter I outlined a realist account of treaties. It claims that a ruler, concerned with the national interest, should comply with a treaty whenever it is beneficial (from the perspective of the national interest) to do so, but violate whenever doing so would further the national interest. In this chapter I treat political realism as a consequentialist theory and distinguish between act and rule variants of realism. I argue in favour of what I shall label 'rule realism' at least with respect to treaties. States should endorse a rule that treaties must be honoured except when certain conditions are met. I return to the Humean considerations concerning the stability of social conventions over time to suggest that once the rule that treaties must be honoured (pacta sunt servanda) has been endorsed by states that it is stable.

\section{The Condition of Warre}

We have seen that, for the political realist, it is an open question whether for any treaty commitment a ruler ought to honour or violate that commitment. The overriding consideration for the ruler, on this account, ought to be to further the national interest. The realist, in short, agrees with Hobbes' Foole who argues that to "keep, or not keep, covenants (is) not against reason when it conduceth to one's benefit" (Hobbes 1965, chap.15). Now, Hobbes himself is often held up as a paradigmatic realist thinker ${ }^{127}$ and,

\footnotetext{
${ }^{127}$ This is largely down to the following passage: "in all times, kings, and persons of sovereign authority, because of their independency, are in continuous jealousies, and in the state and posture of gladiators; having their weapons pointing, and their eyes fixed on one another; that is, their forts, garrisons, and guns
} 
at times, he does seem to endorse the Foole's position. A joint promise, where one party must trust in the future performance of the other, is in the "condition of Warre of every man against every man...upon any reasonable suspition...Voyd" (ibid, chap.14). ${ }^{128}$ Although Hobbes qualifies his claim with the requirement that a suspicion must be 'reasonable', when it comes to determining what counts as a 'reasonable suspicion' in the 'condition of Warre' everyone "judges of the justnesse of their own fears" because there is no effective higher power to which to appeal. The 'reasonable suspicion' qualifier appears to be rendered effectively meaningless. One who naively trusts in their fellow promisor and keeps their side of the bargain anyway "does but betray himself to his

upon the frontiers of their kingdoms; and continual spies upon their neighbours; which is a posture of war." (Hobbes 1965, chap. 13). The claim that states are in a condition of war is not unique to Hobbes or even the so-called 'realist' tradition. It can be found, too, in Kant for example (Tuck 1999, 208 - 214). Hobbes does go on to say that "[b]ecause [states] uphold thereby, the industry of their subjects; there does not follow from [the posture of war], that misery, which accompanies the liberty of particular men" (Hobbes 1965, chap. 13). As we saw in chapter 6, Hume agrees with this claim and bases the 'shocking maxim' upon it.

${ }^{128}$ By 'war' Hobbes does not mean just a period of actual fighting. As Hobbes puts it; "War consisteth not in battle only, or the act of fighting, but in a tract of time, wherein the will to contend by battle is sufficiently known...the nature of war consisteth not in actual fighting, but in the known disposition thereto during all the time there is no assurance to the contrary." (Hobbes 1965 chap.13). So, for example, the Cold War of (approximately) 1947 - 1991 counts as a condition of war for Hobbes. (It is also the background for the INF Treaty which I discussed earlier). 
enemy" which, Hobbes argues, is contrary to the (non-alienable) right that he has to defend his life..$^{129}$

This situation of war, Hobbes suggests, is what we find when we look at the relationship between states (ibid, chap.13). It is unlike the situation within many states where there is some effective coercive power able to enforce promises and settle disputes and where, Hobbes thinks, promises are not 'Voyd' precisely because each party has assurance, in the form of the power of the state, that the other will do what they promised. Treaties, then, are, on this reading of the Hobbesian view, non-binding. Properly speaking they are not genuine promises at all. ${ }^{130}$

\footnotetext{
${ }^{129}$ Machiavelli offers a similar argument suggesting that "in order to maintain his state [the Prince] is often forced to act in defiance of good faith" (Machiavelli 1988, chap. 18).
}

${ }^{130}$ It might be argued that this 'state of war' does not exist in the relations between all states because some states are so much more powerful than the rest. So, we might wonder why the United States should fear a much smaller state. This seems to be troubling for Hobbes' argument, in particular, as it seems to be based upon the claim that people (or states) are roughly equal in their capacity to harm one another (Hobbes 1965 chap.13). As AP Martinech notes, however, recent military redeployments of US troops, from, say South Korea, to Afghanistan and Iraq weakened the United States because they allowed states hostile to the US to act in ways the US would not have tolerated. (The same is arguably true of some nonhostile states in South America). And this is not to mention the economic clout that can be wielded by some states or even a collection of smaller states (Martinech 2005, 75).

Such an argument would not seem to trouble the Machiavellian realist in the same way. If the USA is more powerful then it just has more opportunities to pursue the national interest as its leadership sees it. Other states, of course, have less room for manoeuvre than the USA in this regard but that need not trouble the Machiavellian who does not base her argument on the rough equality of states in any case. 
This Hobbesian inspired picture of international affairs as a condition of war remains popular amongst realist writers. It often goes by the short-hand name of 'anarchy' and, we are told, that it "fosters competition and conflict" (Grieco 1988, 485), "forces states...to act aggressively toward each other" (Mearsheimer 2001, 3), gives rise to "a state of war...(even) if all states seek only to ensure their own safety" (Waltz 1988, 43-44), and that as a result "states in anarchy cannot afford to be moral... (because) moral behavior rests upon the existence of an effective government" (Art and Waltz 1983, 6). Trusting others to keep their word, and uphold their treaty commitments, just because they have given their word is dangerously imprudent in such circumstances.

Many realists, then, assume an analytical model of international relations that renders international relations war-prone (Beitz 1979, 35). Given this, no state has an interest in constraining its pursuit of the national interest by following moral rules such as a rule requiring treaty compliance. Further, and as a result of the structural features of international relations, appropriate normative principles for rulers to abide by must be justified by appeal to the national interest. As we have seen, this means that states appear to have no general obligation to comply with treaties because it is always possible that the national interest of the state will be best served by violating the treaty in question. This does not mean that states will never do what they say they will do but, on the realist view, they will not, and should not, do it simply because they believe they have an obligation to uphold a promise. They do not. Treaties are not analogous to promises in this way.

Many critics of realism, including those who want to draw very different normative conclusions, are critical of this underlying model of international relations. Such critics point out that, as a matter of fact, the relations between many states are far more peaceful 
and ordered than realists suggest. ${ }^{131}$ These critics may well be correct but I shall not pursue this further. ${ }^{132}$ Notwithstanding these criticisms many realists continue to hold that international affairs represent a hostile environment for states. It will be useful, for the sake of argument, to allow them this. We should expect that the realist's normative prescriptions regarding treaties will be most plausible in these circumstances. If we have reason to doubt the realist arguments about treaties in the condition of war then we will also have good reason to doubt them in more benign conditions, should any exist. I return to this explicitly later when I consider what I shall call the stability of a rule requiring treaty compliance.

I think that we do have reason to doubt the realist view of treaties. Even if we accept that rulers of states operate in a hostile international environment and that they ought to act to further the national interest I think that treaties are, all else being equal, binding on states. Indeed, I think that they are morally binding. As a normative position, the realist position, I suggest, begins to look a lot like Treaty as Promise, though with some important qualifications.

\footnotetext{
${ }^{131}$ See, for example, Charles Beitz's Political Theory and International Relations (1979, 35 - 49).

${ }^{132}$ I think that the realist position seems to have something interesting to say about at least some international interactions. So, for example, it does seem dangerous for the USA or USSR to unilaterally disarm in the example of the INF Treaty. In this instance the Cold War at least approximates to the Hobbesian "condition of Warre". So, the realist's analytical model plausibly holds for at least some states at some times. Even if, as a matter of fact, it does not hold for any states here and now it is still an interesting theoretical position insofar as it suggests that under certain conditions treaties will fail to be binding in the way that promises are.
} 


\section{Realism as a consequentialist theory}

Realism, at least the strand that I have focused upon in this chapter, is a consequentialist theory, although many realists would deny that it is also a moral theory. ${ }^{133}$ (If it is not also a moral theory then it differs, in this respect, from perhaps the most familiar consequentialist theory, utilitarianism).$^{134}$ It is a consequentialist theory because it evaluates the acts of rulers according to the value of the likely outcomes of those acts (see Kavka 1986, 357 - 358). Unlike utilitarian versions of consequentialism the outcomes are not evaluated in terms of the maximization of overall wellbeing but, rather, in terms of the national interest of the state on behalf of which the ruler acts. Faced with two or more possible courses of action the ruler of a state ought to choose that action which, given the

\footnotetext{
${ }^{133}$ Another notable strand of realist thinking discusses the virtues associated with successful statesmanship. Machiavelli is, perhaps, the clearest exponent of such a position although, even here, an account of what counts as a virtue in a ruler is often tied to the value of the (expected) effects of political acts often understood in terms of the 'glory' of the state. More recently CAJ Coady has argued that realist attacks upon morality should properly be understood as attacks upon the vice of moralism (an excessive regard for morality even in areas where it is not appropriate) (Coady 2008, 15 - 49). It is difficult to find examples of deontologically minded realists as it is deontological theories of morality which are often the target of realist attacks (see, for example, Hoffman 1998, 152). However a number of realists do seem to think of the pursuit of the national interest in these terms (see, for example, Osgood and Tucker 1967,
} 304 n71; Morgenthau 1951, 33- 39).

${ }^{134}$ Some similarities between utilitarianism and realism are explored in 'Morality and Pessimism' by Stuart Hampshire (Hampshire 1978, 1-22). 
evidence available to the ruler, is most likely to further the national interest to the greatest extent possible. ${ }^{135}$

\section{The consequences of what?}

I have suggested that normative versions of realist theories can best be understood as versions of a kind of consequentialist theory. Successful political action is action most likely to further the national interest of the state. So far I have assumed that realism evaluates particular acts. So the decision whether or not to violate a treaty should be made by considering which action, violation or compliance, will most likely best further the national interest in the circumstances. This, as we have seen, seems to be the position of Hobbes' Foole and, at least in some places, Hobbes himself. It is also, apparently, the position of Machiavelli when he argues that a prudent ruler should not keep his word whenever doing so is disadvantageous to the state of which he is ruler (Machiavelli 1988, chap. 18). A similar position is at least implied in the work of other realists (Morgenthau $1954,9)$. Evaluating particular acts of rulers in terms of their consequences for the national interest is, in any case, a criterion of rational choice for rulers consistent with the realist position as I have so far explained it. By analogy with a variant of utilitarian consequentialism we can label such a position 'act realism'.

\footnotetext{
${ }^{135}$ Sometimes realists talk as if this is what rulers ought to do morally speaking, usually by appeal to the moral significance of the national interest (see, for example, Morgenthau 1951, 33 - 34) but usually they do not, being generally sceptical of the place of morality in international affairs (see, for example, Morgenthau 1954, 12; Art and Waltz 1983, 6). I leave the question of the moral status of the realist's consequentialist theory to one side for the moment and return to it below.
} 
But realists do not have to focus on particular actions. Just like utilitarian consequentialists they might evaluate rules requiring certain kinds of actions in terms of the expected outcomes of agents following, or sincerely attempting to follow, those rules (Kavka 1986, 358). ${ }^{136}$ So, for example, a rule requiring treaty compliance would be justified, on this view, if a sincere attempt by a ruler to follow that general rule on each occasion would produce the best expected outcomes for the state of which she is ruler compared to any feasible alternative rule. We can label this position 'rule realism'. Some realists do seem to hold something like this view. For example when he is not agreeing with the Foole (who he generally thinks is foolish) Hobbes is a rule realist.

I think that realists should be rule realists, at least about treaties, and will argue this in a moment. There is, however, a condition that must be met if we have any hope of making rule realism acceptable to those who endorse a realist position. This is that the rule must be such that (enough) other rulers can actually be motivated to comply with it most of the time. Following Rawls let us call any rule that meets this qualification 'stable' (Rawls 1971, 454 - 458). Without this qualification being met the rule realist position would seem to be a non-starter from the realist's perspective. A state could follow a general rule requiring treaty compliance. But it is unlikely that doing so will further the national interest of that state where (enough) other states will not do likewise.

The general problem is that states that decide to comply with the rules, such as rules requiring treaty compliance, run the risk of doing so in a world where other states will not reliably follow those rules because they are act realists. Rule followers risk being

\footnotetext{
${ }^{136}$ Note that this is not the same thing as adopting a conditional strategy of following certain rules of thumb noted earlier. Rules of thumb are followed when the likely costs of constant calculation of outcomes will outweigh the anticipated gains of calculation in each instance.
} 
victimized and exploited by act realist rulers and states. We saw Hobbes give a version of this argument, above, and it appears in other realist writing too (see, for example, Mearsheimer 2011, 427 - 430). In such a world it would appear to pay to be an act realist about treaties. So any plausible challenge to act realism, on grounds acceptable to the realist, must at least offer some account of how any purported rule would be stable enough to make it rational to follow that rule.

\section{Why be a rule realist about treaties?}

The two varieties of realism that I have identified, act and rule, are analogous to act and rule variants of utilitarian consequentialism. The literature regarding the various merits of act and rule utilitarianism is large. There is also some discussion of act and rule varieties of egoism (Kavka 1986, 357 - 384). All of this is to say that the reasons I shall give here to prefer rule realism to act realism are by now well-known and I shall not dwell on them long. However, one reason sometimes offered to prefer rule to act utilitarianism is that the latter apparently cannot account for our moral practice of promising, at least not without struggle. This objection need not bother the act realist who, I have suggested, denies that treaties are properly speaking promises in any case. Instead, then, I shall argue that there are good realist reasons to want to have available a practice of promising amongst states. Act realism seems to rule out having such a practice whilst rule realism does not. Act realism is, I suggest, pragmatically self-defeating. ${ }^{137}$

\footnotetext{
${ }^{137}$ Act utilitarianism is sometimes held to be pragmatically self-defeating in much the same way. See, for example, Norcross 2011(220 - 221) for just such an argument. Norcross defends act utilitarian accounts of promising.
} 
The question of which set of rules is most likely to best serve the national interest of states is difficult. In part this is because there is a difference between rule realism as a criterion for selecting rules for each state and the particular rules that arise from application of this criterion in any set of circumstances (see ibid, 359). In principle rule realism as a criterion of choice need not pick out the same rules for every state. Nevertheless it is plausible, for reasons I shall give in a moment, to suggest that there should be a general rule requiring compliance with treaties (unless certain generally accepted excuses for non-compliance are relevant) if such a rule is to be had: that is, if enough states will be reliably motivated to comply with it.

Imagine the following rule: there is a duty for a state to comply with a treaty just in case that state benefits from compliance with that treaty. Although this is a general rule and would plausibly motivate general compliance amongst realist rulers it is extensionally equivalent to the act realist position. We can also imagine a rule which is identical to this rule except that it places no such condition on the duty to comply with a treaty. It is this latter rule which, I suggest, the rule realist (and hence the realist) should endorse.

The main reason why realists should be rule realists of this latter sort is that widespread conformity to such a rule would render treaties binding in much the same way that promises are usually thought to be binding. And the ability to enter into binding promises is extraordinarily beneficial to both promisors and promisees. We have already looked at some instances in which the ends desired by treaty makers are threatened because each side faces great difficulties convincing the other(s) that it would do its part. So, for example, the USA entered into the INF Treaty because Soviet disarmament would be beneficial to the USA. But, given the USSR had the same aim, the USA faced the difficulty of getting the Soviet leadership to believe that it would, indeed, disarm. The INF Treaty is 
an example of a kind of mutually beneficial agreement requiring cooperation over time and such kinds of cooperation are common. The ability to make binding commitments helps to make such cooperation much easier and more efficient than it would otherwise be.

Nor are such issues an outdated feature of the Cold War, of historic interest, perhaps, but hardly of pressing contemporary concern. Consider the case of Iran and the USA. The USA wants Iran to stop its nuclear weapon building program. And Iran wants concessions from the USA both now and continuing into the future. The USA and Iran are in a position where a mutually beneficial agreement is possible. From the Iranian perspective possessing nuclear weapons would give the country some security against foreign intervention. However, building nuclear weapons is expensive and the benefits to Iran of doing so will be indirect. They are unlikely to directly see sanctions lifted and financial, and other, aid paid by other powers. From the US perspective a nuclear Iran is a threat to peace and stability, and American interests, in the Middle East. The USA could offer concessions to Iran now, with a commitment to continue them into the future, in return for an Iranian commitment to dismantle its nuclear program. ${ }^{138}$

\footnotetext{
138 The negotiations with Iran are more complex than I have space to go into here. For a recent news report giving some indication of the current state of the long, drawn out negotiations see Justyna Pawlak and Louis Charbonneau, 'West considers early sanctions moves in troubled Iran talks', Reuters July $18^{\text {th }}$, 2014, available at http://uk.reuters.com/article/2014/07/18/uk-iran-nuclear-sanctions-
} idUKKBN0FM1IS20140718 (accessed 23/07/2014). 
Both sides face a commitment problem. Although there is a deal that would leave both sides better off than they would be if Iran was to continue its nuclear program, without the ability to make credible commitments such a deal looks to be unrealisable. The USA would not want to offer Iran concessions now unless Iran, in turn, dismantles its nuclear weapons program. The problem is that Iran could simply take the concessions now and continue to build its nuclear capabilities in secret. The USA, realising this, has little incentive to offer whatever concessions would be necessary to lead Iran to dismantle its nuclear program. Nevertheless, if the USA does offer immediate concessions, Iran will have no guarantee that the USA will continue to pay those concessions into the future. Iran, after all, knows that the USA would have reason not to do so. Paying concessions is expensive and Iran, by keeping the agreement, would be left with few means to actually enforce the agreement.

Iran's fear will be that if it dismantles its nuclear program now, this will enable the USA to be in a position to effectively stop the concessions in the future. As an alternative to accepting a deal with the US, Iran could pay the upfront costs of nuclear weapon building now and then attempt to exploit this additional power to force the USA to continue giving concessions into the future. This is more attractive from the Iranian perspective than the situation in which it loses both its nuclear capabilities and US concessions. But it is not as attractive as a situation in which it receives US concessions without having to bear the significant upfront costs of nuclear proliferation.

http://williamspaniel.com/2013/02/26/negotiating-with-iran-credible-commitment-problems/ (accessed 24/07/2014). 
A nuclear Iran is worse for the USA than a non-nuclear Iran. The USA could hope to buy off Iran with concessions that are less costly to the USA than the costs they would need to bear when faced with a nuclear Iran in the future. The major problem, as we have seen, is the USA's inability to credibly commit to continue providing concessions in the future once Iran has kept its side of the deal. If the USA could credibly commit in this way then Iran would have no reason to proliferate. But, Iran expects the USA to renege on the concessions, which in turn leads Iran to continue its nuclear proliferation.

The prospects for a mutually beneficial deal between the USA and Iran may yet seem some way off. And we should not expect that having the ability to make promises will result in the immediate amelioration of the situation. Nevertheless, the prospects for a mutually beneficial agreement look bleaker still in a world where credible promising is not an option. And similar agreements have worked in the past. For example, Egypt's nuclear program was dropped after the Camp David Accords in return for the Sinai Peninsula and (still) ongoing financial support to Egypt.

Promising is a versatile tool. Consider again the many uses to which a promise can be put in an individual human being's life. As with Iran and the USA, above, and the USA and the Soviet Union, and the states entering into the Kyoto Protocol to collectively combat devastating climate change, individual human beings can use promises to make the kinds of commitments that overcome the potential conflicts that inhibit mutually beneficial cooperation. This, after all, is the point of Hume's story of the two farmers from chapter 1.

But conflict is not the only problem that states or individual human beings face. Earlier I mentioned that states sometimes simply want to coordinate on some set of common rules or measures. I noted that the International Bureau of Weights and Measures (1871) was 
like this. Although there may still be some source of conflict, if, for example, states want their own preferred standards adopted, it is normally the case that adopting common standards, whatever these are, is preferable to not doing so. A promise, or treaty, is an efficient means of coordinating the expectations of a large group of states. By means of promises states can credibly, and efficiently, commit to a shared course of action.

We can reasonably expect more mutually beneficial cooperation with the ability to selfbind than we can without it. Recognition of a rule requiring treaty compliance, together with awareness that one's treaty partner also endorses the rule, offers one way to secure these benefits so long, at least, as enough others also act according to the same rule. ${ }^{139}$

\footnotetext{
${ }^{139}$ Some contemporary realists may object at this point and argue that I am assuming that rulers acting in the national interest seek absolute gains for their state. A number of contemporary realists argue that states instead pursue 'relative gains' (see Waltz 1979, 105; Grieco 1988; Mearsheimer 1990, 44 - 45; Mastanduno 1991, 78; and Walt 1998, 35). This means that states aim to increase the gap between their wealth and power (or whatever it is that they are pursuing) and the wealth and power (or whatever) of other states. It would be like Hume's two farmers not only seeking to cooperate in order to make the most money each that they possibly can but also seeking to increase the gap between their wealth and the wealth of the other (possibly in order to use that wealth to harm the other in the future). If we accept this then states will have some reason not to want to be able to bind themselves, say by making promises, as this will deny them the flexibility to pursue relative gains.
}

I do not have space here for a full discussion of the realist notion of relative gains. I will note that the attempt to get the most one possibly can out of a bargain relative to the party one is bargaining with is quite normal in negotiation between most agents and not just states. Buyers and sellers in a market will typically compete over the costs of goods but we do not say that they are seeking relative gains. Instead, as Donnelly argues, they are competing over the distribution of the gains in order to maximize their expected returns. In order to do this they rely on promises (and contracts). Realists offer little reason to 
So, the ability to make treaties that are also promises, in that they are self-binding, is advantageous for states. Can a society of states behaving as act realists say they ought to act realise these benefits through treaty-making? On the face of it, it does not look like they can. At least, they cannot do so simply by making promises to one another. Why not? Consider again the example of the INF Treaty. In order to gain the benefit of the INF Treaty, Soviet disarmament, the USA intends to get the USSR to believe that it plans to carry out the terms of the treaty and that it will not fail to do so on the grounds that there is some alternative action which will be better for the USA. If the USSR does not believe this then it has no reason, at least no reason offered by the treaty, to disarm. The treaty itself is supposed to give the USSR this assurance. Imagine, now, that the leadership of the USA is committed to act realism and that the leadership of the USSR knows this to be the case because every state, including the USSR, behaves as the act-realist says they ought to act. In this case the USSR will believe that the USA will only comply with the treaty if there is no alternative course of action open to it which will be a little better for the USA. Now, if it is also the case that the USA knows that the USSR knows this then they will also know that the treaty will fail to get the USSR to believe that they intend to comply with the treaty whenever there is some alternative action which will be better for them. So it looks as though the act realist USA cannot use the treaty to give the USSR the assurance it needs to disarm. Indeed the USA cannot even genuinely intend to get the USSR to believe that it will carry out the terms of the treaty given a chance not to do so (Norcross 2011, 221). The USA cannot make a promise to the USSR. But there seem to be good

think that states are not simply competing over the distribution of absolute gains and that attempting to get more from a deal relative to one's partner is just one way of pursuing that end (Donnelly 2000, 58 $60)$. 
reasons, on realist grounds, to want something at least analogous to the practice of promising. Act realism seems to rule this out.

Of course the act realist can point out that states can give each other the assurance required to realize cooperative benefits in ways other than promising. I have already noted that states can, and do, employ various kinds of monitoring device to determine the compliance of the other party. So the USSR might be able to witness the USA's disarmament and, in turn, disarm itself. And the USA might be able to witness the USSR's disarmament. Although the treaty, as such, does not bind either party, or motivate disarmament, it does signal that both parties believe the purpose of the treaty, mutual disarmament, to be a worthwhile aim and it allows them to focus their attention on monitoring and enforcement mechanisms. ${ }^{140}$

So the act realist can offer genuine alternatives to promising as means of self-binding in order to promote mutually beneficial cooperation over time. Nevertheless achieving cooperative dividends by use of monitoring regimes is likely to be harder, more time consuming, and more costly, in terms of time and resources, than achieving the same ends by promising. In some cases, such as that of Iran and the USA, above, it is not even clear that a monitoring regime would ensure continued compliance especially of the USA's ongoing commitment to future concessions.

\footnotetext{
${ }^{140}$ Historically, rulers would use an exchange of hostages in order to enforce treaties, especially peace treaties. These mechanisms can also be used amongst individuals who have little reason to trust one another although it is more likely to take the form of refundable down payments than the exchange of people.
} 
Prudent act realist rulers must also continue to calculate the likely consequences of treaty compliance versus violation over time and also correctly guess how their treaty partners will calculate the consequences of their various options for action. But such calculation, as well as being difficult, is subject to error particularly under conditions of uncertainty and when the stakes are high. Coordination and cooperation that promotes mutual advantage are greatly aided when all of the relevant agents must act according to the same set of general rules including the rule that treaties must be kept. In short, although assurance can be given on the act realist account there is a more efficient way of doing the same thing and this is by treating treaties as kinds of promises. This is not open to act realists but does appear to be open to rule realists.

If a practice of promising is to be had in international affairs, that is, if such a rule is, or would be, stable, then there are good realist reasons to endorse that rule. A world of states behaving as act realists might be able to gain some of the benefits of promising by other means but, insofar as they can, this comes at additional cost to those states. The rule that treaties should be complied with should appeal to the realist ruler, at least insofar as she is at her rational best, and so long as enough other rulers can be relied upon to act according to the same rule. It is a rule with which she should be willing to comply if that were the cost of everyone else doing the same (Davis 2006, 350).

\section{The Rationality of Rule Realism}

\section{$\underline{5 a .}$ Is rule realism really rational?}

A world of known act realist rulers cannot make promises and this is a loss, on realist terms, for those rulers. The act realist might concede the desirability, in principle, of rulers being able to make binding promises to one another but point out that a canny 
ruler could comply with almost all of her treaty commitments whilst judiciously violating those where the likely benefits of doing so are high and the risk of detection by others is low. If she is really canny she will be able to maintain a reputation for treaty compliance whilst violating treaties. For any given rule, such as the rule that treaties must be kept, it is always possible that a ruler could expect to bring about better consequences, in terms of the national interest, by violating the rule in that particular instance. In any given instance where a ruler can reasonably expect to further the national interest better by treaty violation, blindly following some general rule of conduct would seem to be irrational (Kavka 1986, 378). This represents a serious challenge to the rule realist view insofar as it is defended in terms of its furthering the national interest of states. I think that the rule realist can meet this challenge. In order to do so I shall adapt an argument made by Gregory Kavka, which he attributes to Hobbes, to international affairs (Kavka 1995; see, also, Hobbes 1965, chap. 15).

First we need to distinguish between two kinds of case in which a ruler might expect to better further the national interest through treaty violation. We have already encountered these when we looked at the INF Treaty and the Kyoto Protocol. A ruler might try to obtain for her state some unilateral advantage by violating the treaty. This will normally take the form of trying to cheat or otherwise deceive one's treaty partners so that they comply with the treaty whilst the deceiving ruler's state does not comply. ${ }^{141}$

\footnotetext{
${ }^{141}$ Such violation may take the form of enjoying the cooperation of others without contributing (as in the example of Canada and the Kyoto Protocol) or taking advantage of others' cooperation to make those others worse off than they would be had they not cooperated (as with the INF Treaty). Philip Pettit calls the latter "foul-dealing" (Pettit 1986, 373). Kavka discusses 'offensive' and 'defensive' violations (see, for example, Kavka 1986, 139; and 1995, 8 - 9).
} 
So in my earlier example Canada might violate the Kyoto Protocol whilst expecting (or perhaps even knowing) that enough others will comply with the treaty to enable Canada to gain the benefits of the treaty without bearing its share of the costs. In this case Canada seeks a unilateral advantage over other states. But other rulers, even those who want everyone to comply with their treaties, will be wary of being taken advantage of by unilateral advantage seekers or by other rulers acting irrationally (for example those seeking military glory). And this is the second kind of case. Here rulers violate through fear of suffering significant losses through the violations of others. They do not seek unilateral advantage but simply attempt to minimize the losses that will likely accrue to their state from the violations of others.

I begin by considering the first kind of case. Is it not irrational for a ruler committed to realism to comply with the general rule requiring treaty compliance when some unilateral advantage could be gained in particular instances by an act treaty violation?

A tempting, but misguided, way for the defender of rule realism to respond to this question would be to deny that such opportunistic treaty violations ever really turn out to be more advantageous to the would-be violator than compliance would have been. Take, again, the INF Treaty and imagine that the USSR has unilaterally complied with the treaty but the USA has not. If the USA violated the INF Treaty after the USSR had already disarmed we might try to argue that the advantages gained by the USA through violation - winning the Cold War, dominating the USSR, being the world's sole super-power, and so on - would be really outweighed by the disadvantages of having violated the treaty. Such a response would need to find a way of denying that it would even in principle be possible 
to come out ahead, all things considered, through unilaterally violating a treaty. ${ }^{142}$ Perhaps such an argument could be made but I am doubtful that it could be made plausible in all instances. In any case the defender of rule realism does not need to make the very strong claim that treaty violation never in actual fact pays.

Instead the rule realist can agree that treaty violation in some particular instances will undoubtedly happen to turn out for the best, all things considered, for the violator. A treaty violator might gain through violation. However the would-be violator cannot reliably know at any given moment of decision whether this case, here and now, falls into that category or not. The defender of rule realism can then argue that it is not reasonable for a ruler to take such a risk with the national interest in conditions of such uncertainty, or risk, given the foreseeable costs of erroneous calculation. In other words, the realist

\footnotetext{
${ }^{142}$ This, for example, appears to be the line taken by Hume when he responds to this challenge in the second Enquiry. Hume argues that the violator, or 'sensible knave', may have gained great power or money through his infidelity but that these are really "worthless toys and gewgaws" compared to what he has lost, "the peaceful reflection on (his) own conduct" (EPM 9.2). Applied to rulers the act realist can argue that this response simply begs the question. Whether or not such 'peaceful reflection' properly comes though having faithfully complied with all treaties or from having judiciously violated treaties for the good of the state is what needs to be decided. Besides it is one thing for a ruler (or anyone else) to have an uneasy conscience and it is another thing for them to have good grounds for having an uneasy conscience.
}

I lack the space to discuss the sensible knave at length. For interesting discussions, putting the knave in the context of Hume's moral theory as a whole, see David Gauthier's Artificial Virtues and the Sensible Knave (1992), which is critical of Hume, and Annette Baier's response, Artificial Virtues and the Equally Sensible Non-Knaves: A Response to Gauthier (1992). Hume (unlike Hobbes and Gauthier) is able to draw upon his Sentimentalist moral theory to answer the knave. 
ruler will more reliably further the national interest over time by following general rules, such as the rule that treaties must be kept, than they would by making decisions on a case-by-case basis. As Kavka points out, this seems to be the argument Hobbes adopts against the Foole (Kavka 1995, 7 - 9). Hobbes does not deny that it is rational to unilaterally violate a promise in any instance where the promisor will, after the fact, gain more through the act of violation than she would through the act of conformity. But we cannot know, ex ante, with certainty on any particular occasion whether or not the specific case that we face is one in which we would ultimately gain from unilateral violation or not. Hobbes, like Hume, tells the realist ruler (and, indeed, all of us) that it is rational to play it safe. The rule that treaties must be kept promises better outcomes for a state than does choosing whether to comply or violate on a case-by-case basis. Why?

Hobbes offers the same kind of answer that we earlier saw Hume give. An agent that unilaterally breaks his promise "cannot be received into any Society...but by the errour of them that receive him...which errours a man cannot reasonably reckon upon as a means of his security" (Hobbes 1965, chap. 15). For Hobbes, of course, the stakes are especially high. To lose one's promising power is to leave one without the ability to make useful, and potentially lifesaving, alliances and enter into defensive confederations in the state of nature. It is to condemn one to being alone in the 'condition of Warre'. For Hume, as we have seen, the stakes are not as high as they are for Hobbes. This is because Hume thinks that the state of nature, a period of time "full of war, violence and injustice", is a "mere fiction" (T 3.2.2, 495). Nevertheless, the power to enter into promises remains of central importance to Hume, and the diminution of that power, through a loss of reputational capital, is bad for any agent. Both Hobbes and Hume think that keeping a 
promise is, all else being equal, rational because it helps to ensure the future cooperation of others. The justification is, ultimately, forward looking (Kavka 1995, 21).

But why should rulers not do better by trying to calculate risks on a case-by-case basis as the act realist thinks that they should? Part of the problem for the act realist is that often in international affairs rulers must make decisions whether to comply or violate under conditions of uncertainty (Jarvis 2011,297). This means that rulers either cannot place a subjective probability on any particular outcome occurring or they do not know precisely which probability applies to a specific outcome.

These decisions are made under conditions of uncertainty for a number of reasons. For example, rulers are often not fully informed about the intentions and goals of those with which they enter into treaties (Iida 1993, 431 - 433). In addition, rulers can sometimes lack full information about their own desired payoffs from an agreement because they are uncertain about where the national interest will lie in the future (see ibid, 448 - 451; and Jervis 1976, 54 - 56). Finally, it must be remembered that rulers, like anyone else, are prone to short-sightedness, self-deception, and various other biases and errors (see Jervis 1976, 172 - 191). ${ }^{143}$ Under such conditions it is irrational to risk undesirable, perhaps disastrous, future consequences in order to achieve uncertain payoffs. ${ }^{144}$ So, for

\footnotetext{
${ }^{143}$ Hobbes makes much the same point when he says that people are "by nature provided of notable multiplying glasses, (that is their Passions and Self-love)...but are destitute of those prospective glasses, (namely Morall and Civill Science,) to see farre off the miseries that hang over them" (Hobbes 1965, chap 18). I thank Lisa Ellis for drawing my attention to this quote.
}

\footnotetext{
${ }^{144}$ Of course, we take risks, and deal with uncertainty, often in our everyday lives. As Russell Hardin notes "we take gambles on potentially awful outcomes in order to accomplish even minor purposes". He gives
} 
example, violating a particular treaty places future trust and cooperation from others in jeopardy. Other potential treaty partners may be unwilling to trust a ruler, or state, that has violated previous treaties with others. In extreme cases states with poor reputations are shunned from participation in treaties and other international agreements (Tomz $2007,21-22$ ) or are punished directly with sanctions or other means.

Now, if states rigidly follow the rule that treaties must be kept (all else being equal) then they will no doubt sometimes miss out on chances to violate treaties that would turn out to be advantageous to them (Kavka 1995,26$)$. So, Canada could secretly violate the Kyoto Protocol whilst pretending to comply. If Canada gets away with this it is unlikely to make any difference to the success or failure of the Protocol (unless there is some threshold level at which Canada's participation or non-participation would make the difference), no other state will be aware of the violation, and Canada can use the resources that would have been spent combatting climate change on some other purpose. The problem that Canada faces is one of determining, ex ante, whether or not the Kyoto Protocol is genuinely an instance where violation makes sense and in which it is worth bearing the costs of getting caught violating the treaty (ibid, 27).

The real danger, from the rule realist perspective, and already mentioned above, lies in the tendencies of decision makers to error and miscalculation. This is not just a matter of

an example of driving on the highway to visit a friend for dinner. "The worst outcome" we are told "would be an appallingly bad encounter with an SUV; the best... a very pleasant evening" (Hardin 2007, 161). The point that the rule realist is making, however, is that we are able to mitigate risks and uncertainties partly by following set rules. On the Humean account these rules take the form of social conventions (such as those that tell us which side of the road to drive on). We can and do, in this way, convert uncertainty into manageable risks (Jarvis 2011, 308). 
erroneous calculation on specific occasions, although this, too, is a danger. Instead, the danger lies, as it does for individual persons in their day to day lives, in a tendency to short-sightedness and self-deception.

Take, for example, Hannah Arendt's discussion of the 'Pentagon Papers' which revealed the deception and lies, and attempted manipulation of public opinion, by US decision makers during the Vietnam War. Arendt notes that there was no shortage of reliable information from US intelligence agencies but that, for some reason, this was ignored by decision makers within the US government. She points to the sprawling government bureaucracy and myriad think-tanks, populated by academic "problem-solvers" who, filled with self-confidence and despite knowing all of the relevant facts, "had only to rely on their shared techniques, that is, on the various ways of translating qualities and contents into quantities and numbers with which to calculate outcomes - which then, unaccountably, never came true-in order to eliminate, day in and day out, what they knew to be real" (Arendt 1972, 36). ${ }^{145}$ Despite having extensive resources and a great deal of information available to them, these decision makers routinely overestimated their own capabilities.

Nor, indeed, are problems resulting from miscalculation, human error, and bureaucratic secrecy an especially new phenomenon. The doctrine of raison d'etat, and the idea that secrecy, deception, and the constant calculation of the national interest is key to successful political action in international affairs, was practiced by diplomats and

\footnotetext{
${ }^{145}$ Arendt also attacks the tendency of these 'problem-solvers' to reduce calculations of risk to certain percentages. She notes that this "is a nice outlook for a gambler, not for a statesman, and even the gambler would be better advised to take into account what gain or loss would actually mean for him in daily life" (Arendt 1972, 37).
} 
statesmen, most famously by Cardinal Richelieu, in Seventeenth Century France. But, as Martti Koskenniemi notes, this practice "prevented the emergence of any coherent French foreign policy for most of the seventeenth century" $(2010,312)$.

Of course, there may seem to be opportunities that offer the prospect of significant gains for treaty violation with minimal risk of the kind of bad consequences noted by Hobbes and Hume. The example I offered earlier, of the INF Treaty where the US has an effective 'Strategic Defense Initiative', or SDI, available to it appears to be such a case. The effective SDI, remember, can guarantee US protection against nuclear attack. In this case it may seem that violating the treaty and becoming the world's only superpower would be rational whilst following the rules that treaties should be kept, and disarming, would be irrational. Undoubtedly there will be situations in which it the certainty of 'getting away with it' is very high. It is not clear that violation of the INF Treaty is one of those. As events following the collapse of the Soviet Union have shown, especially since $9 / 11$, being the world's only superpower is not, in itself, protection against terrorist attacks and costly wars. Although tempting opportunities to make massive gains through treaty violation, perhaps without subsequent discovery, will no doubt, from time to time, appear, these opportunities will be rare. The danger, from the rule realist perspective, remains the same as those noted above. Decision makers, caught up in immediate events, will run the risk of short-sightedness and self-deception and misidentify the chances of success (Kavka 1995, 26 n. 50).

It should be noted that such considerations seem more pressing, not less, in the realist's condition of war, for here uncertainty is typically combined with very high stakes indeed. In such conditions those left out of future cooperative endeavours do not merely lose out on useful trade deals or face higher borrowing costs, for example, but also run the more 
significant risk of being ostracised from treaties promising mutual defence. In short a ruler is likely to do better, overall, by following the rule that treaties must be kept than by relying upon case-by-case calculation especially where the payoffs are uncertain, the risks of failure are serious, and the chance of human error high.

\section{5b. Are there any exceptions to the rule?}

Let us turn, now, to the second kind of case. Here the ruler of a state does not seek to gain some unilateral advantage through treaty violation. They are convinced that it is rational to play it safe and follow the rules instead of seeking unilateral advantage on a case-bycase basis. We can also assume that they want every other ruler, and hence every other state, to comply with their treaties. However rule following, and hence treaty compliance, might threaten significant losses in some instances where it is known, or at least reasonably suspected, that the other party or parties to the treaty will violate it for some reason. In this kind of case the mutual advantage expected to accrue from mutual compliance with the treaty is not to be had (unless the violator can be persuaded to comply). The ruler that nevertheless complies with the treaty puts her state at a disadvantage in its relations with others. Might she not reasonably ignore the rule requiring treaty compliance in these circumstances so as to attempt to minimize the losses that will otherwise accrue to her state?

In some instances the kind of reasoning explored in the previous section will be applicable to attempts by states to minimize their expected losses through treaty violation. States, after all, continue to operate under conditions of uncertainty. So a state may be faced with an apparent act of treaty violation by one of its treaty partners. But it can often be difficult to tell whether treaty violation is an act of wilful violation, perhaps to achieve a unilateral advantage, or whether the violation has occurred due to some 
misunderstanding of the requirements of the treaty or some other conditions outside the state's control (see Chayes and Chayes 1995, 1 - 28). If the case is of the latter sort then there may be means available short of treaty violation to avoid incurring losses. However, it is certainly possible for it to be known, or at least reasonably suspected, that the violation of a treaty by one's treaty partner(s) is not innocent. Furthermore, in some instances, where the stakes are sufficiently weighty, it would seem to be prudent to violate the treaty in order to avoid the risk of incurring grave losses.

The INF Treaty is plausibly such a case. Here I asked us to imagine that the USA had not disarmed and the USSR knows this. The USSR must decide whether or not to comply with the treaty and risk unilateral disarmament. Now, the USSR is operating under uncertainty. To illustrate this, let me adapt an example given by Kavka $(1986,143)$. There is some probability (P) that treaty violation by the USSR, and a refusal to disarm, will at some point result in catastrophic nuclear war. There is some probability $\left(\mathrm{P}^{*}\right)$ that compliance with the treaty, and disarmament, will result in losing the Cold War and being dominated by the USA, which is a disaster for the USSR but not nearly as catastrophic as nuclear war would be. Now, the USSR has good grounds to believe that P is much less likely than P* but it does not know how likely either is. What should the USSR do? Even if we know that the best outcome, from the perspective of the national interest, lies in peaceful defeat rather than nuclear war, it is at least plausible to suggest that adopting the course of action that minimizes the probability of the USSR suffering any disaster would be rational and this would be to violate the treaty and refuse to disarm. Here decision making under conditions of uncertainty, with a few minimal, plausible, 
assumptions, suggests the rationality of violating the treaty in order to avoid disaster. ${ }^{146}$ Rigidly following the rule that treaties must be kept would, it appears, be potentially disastrous for the USSR in these circumstances. The USSR would play it safest, it seems, by violating the rule and the treaty and not unilaterally disarming. Rule realism, like Treaty as Promise, seems to require of the USSR a course of action that increases the probability of disaster. This is troubling for rule realism as the relevant rule is justified by its contribution to the national interest.

The obvious rule realist response is to claim that we have misunderstood the relevant rule as requiring compliance with treaties in any circumstances whatsoever. Even if it would be rational to follow such a rule in cases where there is some chance of unilateral advantage, as I have suggested above, it does not seem to be rational in cases in which rulers are most concerned with defending their state against the consequences of treaty

\footnotetext{
${ }^{146}$ On the other hand the worst outcome of unilateral disarmament (losing the Cold War) is not as bad as the worst outcome of failing to disarm and so application of a rival criterion of rational choice under conditions of uncertainty (maximin) would recommend unilateral disarmament. Sometimes, however, maximin will also require treaty violation. For example, the Soviet Union may have broken the Ribbentrop-Molotov Pact with Nazi Germany by preparing for war because it believed (with justification) that Nazi Germany was also preparing to violate the treaty. Here it is plausible to suggest that the worst outcome of treaty violation (fighting) is not as bad as the worst outcome of treaty compliance (being conquered by Nazi Germany). In any case the point is that under conditions of uncertainty, which seemed to argue in favour of rule following rather than unilateral advantage seeking through treaty violation, it is at least plausible to say that defensive treaty violation is rational in order to avoid disaster. In short, whether or not a ruler should violate a treaty in order to defend her state is an open question for the realist. (See Kavka 1986, 143).
} 
violation by another party. Perhaps, then, we should modify the rule to something like the following:

Treaties must be kept except when those with whom the treaty has been made have violated the treaty or where it is reasonably suspected that they will violate and where such violation would be to the disadvantage of the compliant party (or parties). In such cases treaty violation is permitted.

This rule still requires rulers to comply with their treaties but it now has a qualifying clause in the form of a permission to violate a treaty when conditions are such that the qualifying clause is triggered. Where the USA has already violated the INF Treaty in a way too damaging to ignore, the qualifying clause of the rule applies.

The suspicion will be that in qualifying the rule in this way, by allowing an 'escape clause', the defender of rule realism has simply adopted an ad hoc solution in order to salvage the theory and that rule realism is, as a result, practically equivalent to act realism. The claim that rule consequentialism collapses into act consequentialism is based on the idea that rule consequentialists will just keep adding modifications to rules in order to deal with any cases where the consequences of following a rule is predictably worse than the consequences of violating the rule. But if we keep adding rules in this way we seem to end up with the practical equivalence of act consequentialism (Fried 1981, 16). This objection has, I think, been successfully met by adherents of rule utilitarianism who typically point to the costs of agents internalizing, not merely following, the relevant rules, such that internalization costs increase as the complexity of the rules increases (Hooker 2000, sec. 4.2). I see no reason why the rule realist cannot also make such a claim but I will not pursue this further here. Instead I want to briefly note some general points that count in 
favour of accepting a qualifier permitting treaty violations wherever some other party has violated, or is reasonably suspected of planning to violate.

The permission to violate a treaty in certain circumstances finds a familiar analogue in the practice of promising as it exists amongst individual human beings. We typically do think that promises should be kept (the rule) all else being equal (the qualifying exception). Mutual promises, in particular, seem to be dependent upon performance by the other party. An agreement, made by invoking promises to one another, to walk together up Mount Victoria would be rendered pointless if one party failed to keep the promise. (Indeed, strictly speaking, in such a case it would not be possible to do what was agreed). But this is not usually thought of as an ad hoc addition to a rule that mutual promises must be kept. It is, instead, part of what it means to make a mutual promise. The rule that treaties must be kept can simply follow the same pattern.

This consideration can be given further support, in the case of treaties, when we reflect on the realist justification of the rule requiring treaty compliance. On the rule realist account we have seen that the rule is justified by reference to the purpose that treaties fulfil in efficiently binding the parties to the treaty for their mutual advantage. If the USA decides to violate the INF Treaty and this is known to the USSR then in this instance conditions (all things considered) are not as the justification of the relevant rule itself presumes. By acting contrary to the relevant rule the USA has effectively undermined the treaty by undermining the purpose of the treaty. The violation of the treaty by the USA denies the USSR the advantage that the treaty must provide if it is to count as a kind of promise at all and that is the binding of the USA (and USSR) (see Davis 2006, 346). Just as the point of keeping the mutual promise to walk up Mount Victoria ceases to exist if one party intends to break the promise so, too, has the point of complying with the INF Treaty. 
This does not mean that all treaty violations should be met with counter-violations. As we have seen, in some instances it may be possible to salvage a treaty, especially where the initial violation was the result of error rather than malice. On the other hand some violations are potentially too damaging to disregard and any feasible rule must be able to account for this. The rule requiring treaty compliance can do so in a way consistent with its own grounds of justification.

\section{The Morality and Stability of Rule Realism}

We have, then, a rule - comply with treaties (so long as enough others will do likewise) that on the face of it looks very much like Treaty as Promise. If we also think that the practice of promising amongst individual persons typically includes some permission to break promises then the analogy is closer still. In short rule realism appears to offer a reasonable interpretation of the practice of promising as it might appear amongst states.

It might be thought that the rule realist account of treaties is not also an account of promising amongst states because promising is, at least in part, a moral practice. The demands the practice of promising places upon promisors are moral demands. We are not merely imprudent if we break a promise. We also violate a moral obligation. But the rule realist account is prudential - the rule is ultimately justified by its contribution to the national interest of each state that follows the rule (assuming enough others do likewise).

It might also be thought that not enough has been done to show that the rule - 'comply with treaties' - would be stable. Would enough states comply with the rule to make it rational for each ruler to comply with it? Or does the fear of violators - however irrational they are - undermine the trust necessary to maintain the rule over time (if, indeed, it could get started in the first place)? This concern arises acutely when we reflect on the 
qualifying clause of the rule which permits treaty violation in circumstances in which the first party has already violated (at least in a manner damaging to ignore) or where there is a reasonable suspicion that they will do so. As we saw Hobbes argue, what counts as a reasonable suspicion is more or less left up to individual rulers. In situations in which the costs of assuming compliance where none is forthcoming are high, as with the INF Treaty, it would seem to be rational often to invoke the qualifying clause. It is one thing to agree to be bound by normative standards that limit the furtherance of the national interest but another actually to constrain international behaviour. Each ruler might think it desirable for every state to uphold its treaty commitments and recognize that, if enough others do so, it is rational to rigidly follow the rule. However, for the rule to be operative this requires a level of collective action that it is beyond the scope of any one ruler to achieve. The rule 'always comply with treaties' may yet turn out to be unstable and rule realism desirable but, ultimately, unobtainable.

I want to begin by arguing that rule realism should be thought of as a moral system and that the rules it justifies should be thought of as moral rules. Ultimately not too much rests upon such a labelling exercise. Accepting it may reduce resistance to the idea that a commitment to realism is somehow inimical to a commitment to genuine moral restraint in international affairs. It may also remove a remaining doubt that treaties cannot be kinds of promises properly speaking on the realist account. Of course, I should note, the same thing can be said to those who suspect that rule realism is no longer, properly speaking, a form of realism. Although I think that rule realism should be seen as a genuine variety of realism not too much rests, again, on such a labelling exercise.

Even if the claim that rule realism is a moral system is not accepted in its entirety, I shall point to one feature of moral systems that is often raised and that is the role that various 
forms of social sanction typically play in maintaining compliance with moral rules (Kavka 1986, 367). This feature, I suggest, is shared by rule realism and, in particular, the rule that treaties must be complied with. This brings us back to the question of the stability of the rule. Once the rule is put into practice we shall see that it is remarkably resistant to destabilization.

\section{6a. Morality}

We have seen that rule realism evaluates rules requiring types of action in terms of the value, understood as the national interest, of the outcomes of relevant agents endorsing and following rules requiring just those types of action. Each ruler ought to endorse and follow those general rules which, when followed, would be most likely to most further the national interest of the state of which she is ruler. Sometimes the general rules chosen might meet this requirement whatever else any other ruler, or state, does. A rule prohibiting treating one's citizens cruelly might be like this. From the perspective of the ruler seeking to further the national interest it does not matter to Britain if New Zealand treated its citizens cruelly. Britain would not expect to be disadvantaged if New Zealand began treating its citizens cruelly whilst it did not. ${ }^{147}$ But other rules are not like this. They

\footnotetext{
${ }^{147}$ As mentioned previously it is also possible for such a rule to be applicable to some states but not to others. It is possible, in theory, for every state to have its own rules. When it comes to treaty compliance there seems to be little reason for states to accept rules that would favour the interests of other states over their own. Of course, each would prefer a rule that grants them exemptions from following the rule in certain cases. However insofar as the benefits of a rule requiring treaty compliance relies upon others also endorsing, and generally following, the rule then each also has reason to select a rule that others
} 
require that (enough) others also act according to the same rule. Following the rule that treaties must be complied with is beneficial but only when others will reliably do the same. Where this condition is not met, treaty compliance would be a risky business. It would risk putting states at a disadvantage in their relations with other states and this, I assumed, would rarely be in the national interest.

What rule realism aims to do is show that treaty compliance is called for by a general rule, such as 'comply with treaties', that it is rational for each ruler (pursuing the national interest) to endorse. These rules provide appropriate standards for defending and criticizing certain forms of international behaviour. It is reasonable to direct complaints against treaty violators, at least those that violate for unilateral advantage or when lacking reasonable suspicion, and it is hard to see how the violator is in a position to reject those complaints (Narveson 2007, 223). Insofar as these standards, in the form of general rules, apply to all states - and because they will sometimes limit what rulers do in pursuit of the national interest - they look, and behave, very much like moral rules. Rule realism nevertheless remains a realist theory precisely because the relevant rules must be justified in terms of the national interest of states. Rulers do not need to choose between realism and Treaty as Promise after all. In fact rule realism looks to reach almost exactly the same conclusions as Treaty as Promise regarding the binding nature of treaty commitments.

It might still be thought that treaties, as the rule realist understands them, are not really promises because the latter are, at least in part, part of a moral practice and, for all the

could also rationally endorse and follow and this seems to rule out rules that permit individually advantageous exemptions. 
apparent similarity, rule realism is ultimately not a moral theory. For example Charles Beitz argues that realism cannot be understood as a moral theory because it is ultimately based on (state focussed) prudential considerations (although Beitz does not consider a rule based variant of realism) (Beitz 1979, 22 - 23). To delve too deeply into meta-ethical questions here would take us too far off course. But I will note that the rule 'always comply with treaties' is prescriptive, insofar as it involves an imperative ${ }^{148}$, generalizable, insofar as it prescribes the same conduct to all (barring relevant differences in circumstance), and is supposed to take precedence over other, rival principles of action, including the short-term pursuit of gain, three commonly cited formal requirements of a moral system (see Hare 1965, 3- 5; Kavka 1986, 366). ${ }^{149}$ Nevertheless, rule realism's

\footnotetext{
${ }^{148}$ The imperative is, it is true, what Kant calls a hypothetical imperative rather than a categorical imperative. If we think that morality consists in categorical imperatives then the rule realist injunction to comply with treaties would seem not to be a moral requirement. Hypothetical imperatives address themselves only to agents that have the relevant ends (so not everyone is required to learn French, only those who have the relevant end). So, if you have a particular end (be able to speak French) then there is something that you should do (take French lessons) that it would not have been the case that you ought to do should you have failed to have that end. The hypothetical imperatives that rule realism posits make use of ends that are actually given (they are 'assertorial' in Kant's terms rather than 'problematic' or 'technical' (Kant 2012, 28)). The relevant end I have taken to be something like 'the security of the state' following most realist authors. A full rule realist account would ideally include some argument to the effect that such imperatives are not only assertorial but also that they are necessarily so (for rational agents) (see, also, Davis 2006, 344 - 345 n. 6).
}

${ }^{149}$ See Kavka 1986, 366 -368 for a discussion of whether or not 'rule-egoism' is properly a moral theory. My discussion of rule realism follows many of Kavka's arguments and so his discussion of morality is relevant to rule realism too. 
realist focus on the national interest might still be thought, by theorists like Beitz, to disqualify it as a moral theory properly speaking. Ultimately I do not think that it matters too much. Rule realism is a coherent guide to international conduct and it is reasonable for rulers to adopt it (assuming that enough others do likewise). Insofar as it requires of rulers treaty compliance, all else being equal, the practical differences with Treaty as Promise are minimal.

\section{6b. Stability}

There is another criterion of moral systems that I have only briefed touched upon but it speaks directly to the stability of rule realism and the particular rule that requires that states comply with treaties. Earlier I noted the Hobbesian-inspired realist argument that there is no room for morality in international affairs because there is no effective body able to enforce the moral rules. The obvious rejoinder to this is that many moral rules are not formally enforced by police forces and courts but we endorse, and often follow, them as moral rules nonetheless. Contracts are (often but not always) formally enforced in courts of law but most promises are not. Nevertheless the practice of promising, with its rule that promises must be kept, is somehow maintained. One reason for this is that the violation a moral rule is typically subject to social sanction. Violations are met with criticism and sometimes punishments. One may, for example, find oneself ostracised from one's community. And the same sanctions are available in international affairs. Furthermore promising, and by extension treaty making, offer us a nice example of how such enforcement can work.

One place to begin thinking about the stability of rules of conduct is to distinguish between ideal rules and actual, that is socially existent and widely recognized, rules that 
promote the (national) interests of the relevant agents. ${ }^{150}$ So, a ruler might come to think that 'always comply with treaties' would be the ideal rule from a rule realist perspective. But if that rule is not already widely recognized then she may face difficulties in getting other rulers to endorse and follow that rule. There is little, if anything, to be gained, and much potentially to be lost, by being the first to adopt and follow such a rule if the benefits of rule following are to be had because (enough) others also follow the rule (Mearsheimer 2011, 427-430). Furthermore, the benefits of adopting a rule arise when the rule succeeds in placing widely understood restrictions on the discretion of rulers. But rule realism would not be effective, in this sense, if it nevertheless permitted agents the discretion to appeal to ideal (but non-existent) rules. So, there are two problems with ideal, but non-existent, rules. Individual discretion is not effectively limited if we allow each agent to appeal to some supposed set of ideal rules. And even if all agree on an ideal rule (or some theorist discovers the best rule of all) there remains the problem of getting enough states to actually follow the rule to render it viable.

We can hope to get around these problems by pointing to the rationality of following actual (beneficial) rules. We might point to the existing, and widely acknowledged, rule that states must comply with treaties. ${ }^{151}$ We might, of course, still wonder how such a rule could have ever arisen amongst self-interested states in the first place. This is the

\footnotetext{
${ }^{150}$ This distinction is discussed by Kavka. He attributes it to Conrad Johnson (see Kavka 1995, 31).
}

\footnotetext{
${ }^{151}$ This is the legal principle which goes by the name pacta sunt servanda. It is also widely understood as a custom amongst states (that is, in theory, states do follow it) and, indeed, this is often understood the source of its legal standing. It may also be a moral principle.
} 
problem alluded to above, that of understanding how any ruler (in the case of rules in international affairs) could be motivated to risk following such a rule without assurance that others would do likewise. Such an answer may well be fairly speculative. In the case of treaties, for example, it appears that the roots of compliance lie in widely shared religious beliefs and a shared belief in divine sanction for treaty violation. ${ }^{152} \mathrm{~A}$ different question, however, is how the relevant rule can be maintained in the face of many apparent temptations to violate the rule. The advantages of the rule 'comply with treaties' arise when enough rulers can be relied upon to follow the rule even when it looks as though there is something a little better that they could do with respect to the national interest. So, for example, if it is correct that treaty compliance was called for by widespread belief in divine sanction for treaty violation, then we can ask how it was that treaty compliance was maintained (if it was) once people stopped sharing such widespread beliefs. Perhaps, of course, it was not and as a result rulers typically fail to follow the rule. If this was the case then any individual ruler would, indeed, seem to be irrational to follow the rule however desirable it would be if only things were different. ${ }^{153}$

\footnotetext{
${ }^{152}$ Jeremy Waldron $(2011,65$ - 68) suggests that treaty compliance was historically closely linked to religious observance. It does not matter much here whether this suggestion is correct or not. The point is that however the practice got going in the first place we still must account for how it can keep going. The suggestion that divine sanction kept rulers in line works well for my purposes because that sanction has, I take it, ceased to be taken seriously by many.
}

${ }^{153}$ The reason that I gave earlier for avoiding the pursuit of unilateral advantage is of little help here. It would be rational to seek unilateral advantage, at least in some instances, if one knew that others were not going to follow the rule in any case. 
We have already encountered one way in which we might try to account for the stability of various forms of cooperative behaviour over time. In some cases agents can expect to interact with one another an indefinite number of times in the future. This can lead them to forego uncooperative behaviour now in order to secure the cooperation of others in the future. Here the so-called 'shadow of the future', the threat of retaliation by one's treaty partner for treaty violations, can lead rulers to calculate that the costs of losing future cooperation can outweigh immediate gains (Axelrod 1984, 12; Oye 1986, 13 - 14). I noted earlier that this need not concern the realist, now act realist, who can maintain that this is just one more calculation for the rational ruler to take into account. Nevertheless, if there is a relevant rule in place, the prospect of repeat interaction might help to explain why rulers generally comply with treaties and why, if they do, it is rational to do so for the rule realist reasons given earlier.

Treaty compliance can be further strengthened by what is sometimes called issue linkage' (Keohane and Nye 2001, 26 - 27). This simply means that states can enforce treaties by threatening to retaliate in regards to some issue if their treaty partner violates a treaty dealing with a different issue. So, for example, a failure to meet treaty obligations relating to arms control might be met with an imposition of an embargo on trade relations with the violating state. In other words, states can punish violators on issues other than those which initially sparked the dispute. The effectiveness of this mechanism is further strengthened when we consider the effects of the decisions of non-state actors, in addition to state actors, on the national interest. For example, Russia has recently sent troops into the Crimea in apparent violation of a memorandum (also signed by the USA) supporting Ukraine's territorial integrity in return for the latter renouncing their share 
of the old Soviet nuclear arsenal. ${ }^{154}$ This point of conflict is, at the time of writing, ongoing. The USA and certain EU countries have responded with economic sanctions, putting into jeopardy the gas revenue upon which Russia is heavily reliant. ${ }^{155}$ In addition to this issue linkage by other states, the Russian stock market, the RTSI, fell by $12 \%$ as a result of panic selling by individual investors in response to Russia's initial intervention. The Russian central bank needed to raise interest rates to protect the value of the Rouble. When President Putin later announced that there was no need for further military intervention the RTSI recovered by $6 \%$. In short Russia would need to pay a heavy price for any future military involvement threatening the territorial integrity of Ukraine. ${ }^{156}$ This, of course, does not mean that President Putin will not pay that price (or let Russia pay that price). At the time of writing it does look like he will. The point is that there are forces, such as the actions of other states and non-state actors such as investors in international markets, that will tend to punish treaty violation.

\footnotetext{
${ }^{154}$ The relevant agreement is the 1994 Budapest Memorandum on Security Assurances signed by Ukraine, USA, Russia, and the UK.

${ }^{155}$ If the EU placed sanctions on Russia's gas supply then Russia could expect to lose about $\$ 100$ billion in export revenue (about one fifth of its total export revenue). Of course, there are costs to the EU too. The costs of imposing sanctions will fall disproportionately on EU states when compared to the US. This represents a problem of coordinating punishment of Russia which I discuss below.
}

\footnotetext{
${ }^{156}$ See, James. B. Stewart, 'Why Russia Can't Afford Another Cold War', The New York Times, March $7^{\text {th }}$, 2014, available at http://www.nytimes.com/2014/03/08/business/why-russia-cant-afford-anothercold-war.html?hpw\&rref=business (accessed 15/05/2014).
} 
These two mechanisms can work to motivate states to comply with treaties. But there is a problem with them. A would-be treaty violator can hope to minimize the punishment it receives by increasing ties with other states. So, Russia, in response to American and European sanctions may simply respond by forming closer ties with China for example. In addition, in some cases there may be little that other states can feasibly do to punish violation. There may be little that a small state like Luxembourg could realistically do to punish Russia for example. In order to effectively punish treaty violation, Luxembourg would need the collusion of a number of states. But on the act realist account each state can hope that others will bear the costs involved in punishing transgressors whilst they continue to gain from interacting with the violating state in question. So, for example, states might refuse to participate in a trade embargo because they hope to enrich themselves by so doing. In other words, for the rule requiring treaty compliance to be beneficial to states, and hence rational to adhere to, states must first overcome a collective action problem. One way of overcoming this problem is to point to the two forms of punishment discussed above. But for these punishments to be effective states must overcome another collective action problem and collude in the punishment of transgressors. If the act realist doubts that states can overcome the collective action problem required to make a rule requiring treaty compliance work, she is unlikely to be persuaded by a response that requires solving another collective action problem. ${ }^{157}$

\footnotetext{
${ }^{157}$ This problem even has a realist name: buck-passing (Mearsheimer 2001, 157 - 158). Rational rulers will allow others to bear the costs of punishment. It also called the 'enforcement problem' in public choice theory (Brennan and Pettit 2004, 270 - 274). So, for sanctions on Russia to be effective requires a significant number of other states to cooperate on imposing those sanctions. However, the EU has more to lose from trade sanctions with Russia than does the USA.
} 
There is, however, a third consideration that will tend to lead states to comply with treaties. We have encountered it in earlier chapters. The idea is that a practice of treaty making can be enormously beneficial to those states able to make it work. If the practice is working, that is if it gets going in the first place for whatever reason, then rulers acting in the national interest will have reason to want to maintain their ability to make use of this practice now and in the future. The willingness of other rulers to enter into treaties with them will depend, at least in part, upon the beliefs that those rulers have about the resolve, competency, and trustworthiness of those with whom they are interacting. In short, the reputation of a ruler, and her state, matters when it comes to having opportunities to enter into future treaties. When the question of treaty compliance arises, a ruler needs to consider, amongst other things, both her reputation and the reputation of the state she represents.

Now, consideration of her future reputation alone will not necessarily lead a ruler to comply with her state's treaty commitments. Domestic political events, including a change of government, might lead to a very different assessment of where the national interest lies, including a desire to reject agreements made in other circumstances or by her predecessors. When the Bolshevik government came to power in Russia in 1917, for example, they simply repudiated Russia's sovereign debts and refused to pay. Lenders soon began to cease lending to Russia despite previous (Tsarist) rulers having built up a good reputation for repaying debt (Tomz 2007, 22). Treaty commitments can operate in much the same way. Third parties can minimize the risks associated with entering treaties with such states just like would-be creditors minimized their risks with respect 
to Russia. ${ }^{158}$ At the extreme they can ostracise them altogether refusing to enter into treaties with them. In this way the actual practice of treaty making can be maintained in the face of isolated acts of violation. Furthermore each state has an incentive to take notice of the reputation of a would-be treaty partner. There is no need to solve a collective action problem for reputation to work to maintain the rule that rulers must comply with treaties.

Finally, the more that states comply with treaties the more beneficial to states treaty making, and compliance, can become. States can obtain increasing returns from treaty making. Successful treaty making can come to have positive coordination effects as states adapt their practices so as to be able to participate in global life. Over time rulers acting in the national interest can come to expect cooperative, treaty based interactions and, insofar as they are rational, will adjust their strategies so as to fit those expectations. Take, for example, peace treaties. As more conflicts are increasingly peacefully resolved the peaceful settlement of disputes will increasingly be anticipated. When this occurs the level of trust increases and peaceful interaction, in the form of peace treaties (amongst other things), becomes more attainable and, crucially, easier to maintain. ${ }^{159}$ Rulers will

\footnotetext{
${ }^{158}$ This means, of course, that rulers can squander a good reputation built up by previous rulers. It is also possible to improve the reputation of one's state. Reputation is dynamic because it relies, at least in part, on the beliefs and opinions of other parties. If these other parties are rational (as the realist argues that they should be) then they will update their beliefs as they receive new information.
}

159 See, Tyler Cowen, 'Crimea Through a Game-Theory Lens', New York Times, March 15 ${ }^{\text {th }}$, 2014. Available at http://www.nytimes.com/2014/03/16/business/crimea-through-a-game-theory-lens.html (accessed $15 / 05 / 2014)$. 
have less and less incentive to make use of the qualifying clause to the rule requiring treaty compliance. And as peaceful interaction becomes more attainable and easier to maintain more conflicts will be peacefully resolved and the more future peaceful settlement will be anticipated. Those still tempted to violate peace treaties will be further dissuaded from doing so by the mechanisms -the shadow of the future, issue linkage and reputation protection - mentioned above. These mechanisms are further strengthened, moreover, as the expected returns from treaty making and compliance increase. ${ }^{160}$ The realist 'condition of war' is far from inevitable. In the language of game theory there is an 'equilibrium point' that favours treaty compliance.

All of these forces can act to maintain the stability of a rule requiring treaty compliance once it has managed to get started. There are no guarantees, however, and it is at least in principle possible for so few rulers to uphold their state's treaty commitments as to render obedience to the rule requiring treaty compliance irrational on (rule) realist grounds. In an article in The New York Times, Tyler Cowen suggests that this is because although there is an equilibrium point in favour of peaceful settlement and treaty compliance, under certain circumstances the opposite is also true. That is, there may come to be an equilibrium point in favour of conflict. Each event in a conflict, such as the current conflict over Ukraine mentioned earlier, increases the possibility that what was

\footnotetext{
${ }^{160}$ As treaty compliance becomes more and more anticipated by rulers acting in the national interest so they will have increasing opportunities to make use of their good reputation. Having a good reputation as a treaty complier will, then, increase in value. If, as I have argued, entering into a treaty is like making a promise insofar as both create reasons for action and insofar as at least one of those reasons for action is a concern with maintaining one's good reputation then the greater the value that reputation has the stronger is the reason to keep the promise (or comply with the treaty).
} 
once a peaceful situation can begin to become undone. Rulers can begin to rely less and less upon negotiated, treaty based, settlement as distrust increases and conflict becomes increasingly probable. ${ }^{161}$ At some point there is a point at which conflict, rather than peaceful settlement, becomes the expected standard form of behaviour. It is the possibility of this kind of point being reached that seems to lead realists to conclude that international affairs are war prone.

In these circumstances, where conflict, rather than peaceful settlement, is anticipated by rulers is an act realist rather than rule realist approach to treaty compliance rational? Not necessarily. In the first place the fact that there may be a point at which conflict becomes standard does not obviously justify behaving in such a way as to make reaching that point more likely. Hume, for example, argues that the risk of a useful rule being undermined by individual acts of violation of that rule is a further reason to follow the rule even in instances where it looks as though one might benefit more by the act of violation.

One might disagree with Hume's claim on the (act realist) grounds that no individual act of rule violation can plausibly be identified as the act which will push international affairs into a condition of war. ${ }^{162}$ Nevertheless this need not concern the defender of rule realism. The permission to violate a treaty under certain circumstances is, as we have seen, perfectly consistent with a rule realist approach to treaty compliance. In this respect rule realism does not differ from many other moral systems that permit certain divergences from the usual constraints in practice. In the case of rule realism the rule based permission to violate a treaty is justified by reference to the purpose of entering

161 See footnote 159 , above.

${ }^{162}$ See, also, the section entitled 'Practice-Consequentialism' in chapter 3 of this thesis. 
into treaties for rulers seeking to further the national interest. We can imagine a world in which there is no serious danger of any state seeking unilateral advantage or otherwise failing to comply with a perfectly good treaty. In this kind of case the principal clause of the relevant rule, i.e., always comply with treaties, will apply. Rulers ought, as a matter of prudence and, I think, morality, to follow the rule. But we have already imagined circumstances where the qualifying clause, permitting violation of a treaty, and the rule requiring compliance, applies. At the extreme we can imagine a world where the qualifying clause always applies and where treaty violation is always permitted (but not required). Such a world is, I think, highly unlikely to occur for the kinds of reasons canvassed above. However, even if such a world were to come to exist the relevant rule requiring treaty compliance would remain operative with the qualifying clause acting as a (moral) permission. This is so even if the actual behaviour of states might look very much like that which is prescribed by the act realist.

Furthermore, the condition of war, that is the world where peaceful resolution of disputes is not expected, is not necessarily also a world where treaty violation is common. At various points in history, such as the period leading up to the First World War, it is plausible to suggest that the condition of war has come to exist. It may well do again in the future. ${ }^{163}$ This, it is true, might affect the kinds of treaties which states enter into. If one cannot rely upon a treaty to bind another party then one is unlikely to make use of treaties in order to protect against incurring significant costs through the actions of a third party. There is nothing unusual or particularly troubling in this. Typically, individual persons do not rely solely upon the word of another when there is the possibility of

\footnotetext{
${ }^{163}$ Recent tensions between the USA and EU countries with Russia over Ukraine may lead some to suspect that we are heading towards the condition of war now.
} 
significant losses. When we buy a house, for example, we usually make use of contracts that can be enforced. This does not mean that we do not also use non - (legally) enforceable promises in other circumstances. Treaties are not enforced in the same way that contracts typically are, and in this respect they are much more like ordinary promises.

Finally, the dynamic role that reputation plays in how rulers approach potential treaty partners means that the stability of the rule, in practice, is highly resilient to individual acts of treaty violation. This is because it is possible to isolate treaty violators in such a way that rulers can reasonably expect to continue to deal with those who will reliably follow the rule requiring treaty compliance.

\section{Conclusion}

Political realism, I have suggested, can be understood as a kind of consequentialist normative theory. It is a consequentialist theory insofar as it judges acts according to the value of the (likely) outcome of those acts. The value of an act, for the realist, is understood by reference to the 'national interest' of the acting state. As with other consequentialist theories, such as utilitarianism, we can evaluate either specific acts or, alternatively, sets of rules requiring certain types of action. In short we can distinguish between what I called 'act' and 'rule' variants of realism. There are good reasons, I have argued, for realist rulers of states to be rule realists about treaties. This means that rulers acting in the national interest should endorse a rule requiring treaty compliance.

In practice, rule realism about treaties begins to look like the view I called Treaty as Promise. The conflict between realism and Treaty as Promise, identified at the end of chapter 7, may not be as acute as it first appeared. Rule realism also shares much in 
common with Treaty as Humean Promise, especially in its focus on self-interested reasons for treaty compliance. Indeed, I have suggested that the reputational concerns highlighted by Treaty as Humean Promise can be used to add further support to the rule realist position. Rule realism, in turn, can further support the Humean claim that there are self-interested reasons to comply with treaties. However, as we saw in earlier chapters, Treaty as Humean Promise is not necessarily restricted to consideration of the national (or self) interest whilst rule realism is. Although Treaty as Humean Promise should appeal to the realist it may nonetheless be used to demand more of rulers than does rule realism. 


\section{Conclusion}

Treaties are closely analogous to the familiar kinds of promises and contracts that we are used to making in our everyday lives. They are entered into by particular kinds of agents - political communities, usually states - and this means that the analogy is not quite perfect. For example, we generally do not think that vicious individual people cannot make, and be expected to keep, perfectly good promises. But many people are uneasy about vicious governments entering binding treaties. Their uneasiness is not misplaced. Governments, as we have seen, enter treaties on behalf of the state and its citizens. The treaty generally binds that state, and those citizens, and so we are right to be wary of those who claim to speak in this way on behalf of others. We should be especially wary if those who make the claim are likely to be as self-interested as Hume leads us to think they will be.

Treaties are also often intended to last many years, perhaps generations. If I make a promise to my bank repay my mortgage, I might come to regret making that promise and wish I had never made it. In some extreme cases I might distance myself from the person who made the promise. I could say, "I just wasn't myself when I made that promise!" Sometimes I may be justified in making such a claim. It may even be sufficient to excuse me from keeping the promise if, for example, I was not mentally competent to invoke the relevant social convention, or I acted under duress or my bank defrauded me. In other cases, however, a refusal to accept as my own my past commitments comes at a cost. It harms my sense of being an autonomous agent, something I have reason to value. The citizens of a state, too, might complain that a treaty they entered was made under duress or was the result of fraud and, just as with my promise to my bank, they may be excused the obligation to keep the treaty. But the future citizens of a state, those who had no say 
in the negotiation or signing of a treaty, might say "we never entered that treaty. We should not be expected to keep it!" And even if the treaty was not extracted under duress or fraud, they would have a point, at least to a point. They did not enter the treaty. But should they be expected to keep it?

Of course, if it is important to those citizens that they see themselves as a part of an intergenerational community, a state in this example, then renouncing a treaty made by that community may hurt their sense of common identity. It may do so in a way that is analogous to my refusal to take my own past commitments seriously. But there does not seem to be anything incoherent or strange about the current citizens of a state denying that the commitments made by their forebears really are their commitments. Indeed, as we saw in chapter 5 , for some people, like Thomas Jefferson, a democratic people cannot be properly bound by the commitments of their forebears. To hold them to those commitments would be to deny them their autonomy.

Insofar as the promises you or I make have value because they are ways of exercising our autonomy and shaping our own lives, they differ from treaties. But this does not mean that treaties are not like promises in another, perhaps more limited, sense. Treaties are a kind of promise insofar as promises are devices for facilitating coordination and cooperation.

It is as devices for facilitating cooperation and coordination that Hume thinks of promises and the value of the practice, or social convention, of promising. It is in order to retain continued access to the useful social convention of promising that each of us, upon making a promise by deliberately invoking the social convention, creates a new, selfinterested reason to do what we have promised. By means of promises we can signal credible commitments, assure others, and facilitate cooperation. Treaty as Humean 
Promise, which extends this account to treaties, holds that the value of treaty making likewise lies in its ability to facilitate coordination and cooperation. Insofar as members of future generations, and future governments, want to be able to make credible treaties in the future, they have some reason to comply with the treaties of the past even if they themselves did not enter the treaty in question.

\section{Treaties in the future}

Clearly much has altered since Hume wrote about international affairs in the eighteenth century. In chapter 6 I noted that Hume thinks his theory of international morality, and treaty making, will change in certain ways as empirical circumstances alter. It is likely that much will alter in the future. We may see a time in which international institutions, such as the UN or WTO, become much more powerful than individual states. Perhaps we are already seeing this happening. It may be these institutions, and not treaties, at least as Treaty as Humean Promise understands them, which come to determine the basic rules and standards regulating international life. It is unlikely that treaty making will become obsolete any more than promises and contracts between individual persons became obsolete with the advent of organized, and increasingly powerful, municipal governance.

A related but distinct, and more significant, change would see international courts, such as the ICJ, empowered to decide treaty disputes and able to enforce those decisions. Currently, states are only bound by the decision of the ICJ if they agree to be bound. Famously, for example, the USA simply refused to be bound by a decision of the ICJ that they did not like in a dispute with Nicaragua (Robertson 2006, 99).

A court with the recognized authority to settle treaty disputes, and the ability to enforce its decisions if necessary, would have important consequences for the range of penalties 
states would face for treaty violation. In the absence of a system of courts with the authority to assess damages and award compensation the penalties for treaty violation are limited. Parties to a treaty can forfeit their reputation, and treaties operate, according to Treaty as Humean Promise, by those parties placing their reputation in one another's hands. And they can also retaliate by refusing to do what they have promised to do. But such penalties are fairly crude.

With a functioning court system we can add further, subtler, penalties for treaty noncompliance. For example, a state may have the option to comply with the treaty or pay damages. The advantages of having such options are that states would be able to enter treaties even with those they consider untrustworthy. States may also be more willing to take greater risks and make more thorough going agreements when there is a 'get out clause' of paying damages should the costs of continued treaty compliance, perhaps over many years, become too high. Again, we can see the germ of such changes in the dispute resolution mechanisms incorporated into some treaty agreements such as the treaties constituting the WTO. The existence of courts able to assess and reward damages would not fundamentally alter treaty making. They would add to, and not detract from, the account of treaties offered by Treaty as Humean Promise.

No doubt, then, international affairs will continue to change just as it has since Hume's time. It is likely, however, that treaties will continue to be made, kept, and sometimes broken. Perhaps they will become less central to the interactions between states. Or perhaps they will come to be more like contracts in developed legal systems with a wide range of penalties attached to noncompliance. We may even hope for a time when treaty making, at least as we understand it here and now, becomes obsolete. For now, and the 
foreseeable future, however, treaty making looks set to retain its central place in dealing with (and sometimes creating) the world's problems.

\section{The importance of individuals}

Some might express concern that Treaty as Humean Promise does not demand enough of states. We have come across some of these worries at various points in the preceding chapters. For some people thinking of treaties as 'mere' promises or contracts does not do justice to the significance and importance of treaty making. They might point, in this regard, to claims about the apparent 'sanctity' of treaties. Or they might, with Jan Klabbers, regret the fact that thinking of treaties as mere contracts undermines the sense of idealism and hope expressed by some treaties, especially those dealing with human rights issues.

Such concerns, I have suggested, are misplaced. Promising and contract making do not exhaust the moral landscape. That the Genocide Convention is a kind of promise, and that signatory states have self-interested reasons to comply with it, does not mean that these are the only reasons, or even the most pertinent or interesting reasons, that states have to act as that treaty requires. Treaty as Humean Promise allows us to distinguish the different kinds of reason that states have to comply with treaties. Sometimes world leaders, perhaps under pressure from their citizens, do respond to moral reasons, to the idealism and hope to which Klabbers makes reference. But it is important to know that we have something else to appeal to, something less noble and idealistic perhaps, when world leaders are tempted to abuse human rights to better prosecute some other policy or goal. 
There is, however, a danger in focusing so closely upon states and their claims and duties. The danger is that individual people will get forgotten. It is important to keep in mind that as important as treaty making is it is important insofar as it is important to the lives and livelihoods of individual human beings (and, perhaps, some other creatures). States, ultimately, are a kind of organizational resource for collections of people. Treaty violation is morally wrong insofar as it (sometimes) renders international order less certain and insofar as individual people, and the groups that matter to those people, come to rely upon the rules and standards established by those treaties, imperfect as they may sometimes be. By means of treaty making billions of people can cooperate to reduce the use of CFCs and (it is reported as I write this) begin to repair the hole in the ozone layer. ${ }^{164}$ Of course, cooperation is not good for its own sake. It can used to realise great harms as well as great goods.

We should recognize the importance of treaty making and understand how treaties can be used to facilitate cooperation. Treaty as Humean Promise offers us a way of doing this. But, in light of the instrumental value of treaties, and the fact that they can be used to realise harms, it is also important to avoid an overly 'moralized' account of treaty making. The Humean account is an account of how a particular kind of device, the convention of treaty making, comes to be created and is used because it is useful. This does not mean, as we have seen, that we cannot make claims about the morality or immorality of treaty

\footnotetext{
164 See, for example, 'Ozone Layer shows signs of recovery after 1987 ban on damaging gases', The Guardian, $10^{\text {th }}$ September, 2014, available at:
} http://www.theguardian.com/environment/2014/sep/10/ozone-layer-recovery-report-shows (accessed 10/09/2014). 
compliance and violation. Clearly there are moral implications to treaty making, compliance, and violation and Treaty as Humean Promise does not neglect these.

I began the introduction with an account of Joshua's peace treaty, on behalf of Israel, with the city of Gibeon. We have subsequently come across treaties that aim to fix oil prices, disarm nuclear stockpiles, hand over dead Sultans' skulls, found international organizations, free up trade, and fix the names of cheeses, amongst other goals. It may be wondered whether such a wide range of undertakings could really have anything in common. I have claimed that they do. Treaty as Humean Promise, the account of treaties developed in this thesis, gives us a way of making sense of all of these treaties as kinds of promises. 


\section{Bibliography}

Anscombe, G.E.M. 1981. 'Rules, Rights and Promises.' In Collected Philosophical Papers, Mary Geach and Luke Gormally (eds.) Vol. II. Oxford: Blackwell: 97 - 106.

Appiah, Kwame Anthony. 2010. The Honor Code: How Moral Revolutions Happen. New York: W.W. Norton \& Company.

Arendt, Hannah. 1972. 'Lying in Politics'. In Crises of the Republic. New York: Harcourt Brace Jovanovich, Inc.

Arneson, Richard J. 1982. 'The Principle of Fairness and Free-Rider Problems'. Ethics, Vol. 92, No. 4: $616-633$.

Art, Robert J. and Kenneth N. Waltz 1983. 'Technology, Strategy, and the Uses of Force.' In The Use of Force, Robert J. Art and Kenneth N. Waltz (eds.) Lanham, Md: University Press of America.

Atiyah, P.S. 1981. Promises, Morals, and Law. Oxford: Clarendon Press.

Aust, Anthony. 2007. Modern Treaty Law and Practice, $2^{\text {nd }}$ edn. Cambridge: Cambridge University Press.

Austen, Jane. 1992. Emma. Wordsworth Modern Classics.

Axelrod, Robert. 1984. The Evolution of Cooperation. New York: Basic Books.

Bacon, Francis. 1825. 'Styx, Or Leagues.' In The Works of Francis Bacon, Lord Chancellor of England, Vol. III, Basil Montagu (ed.) London: William Pickering. 
Baier, Annette C. 1985. 'Promises, Promises, Promises'. In Postures of the Mind: Essays on Mind and Morals. Minneapolis: University of Minnesota Press. 174 - 206.

- 1992. 'Artificial Virtues and the Equally Sensible Non-Knaves: A Response to Gauthier'. Hume Studies, Vol. 18 No. 2: 429 - 440.

Baron, Marcia. 1982. 'Hume's Noble Lie: An Account of his Artificial Virtues.' Canadian Journal of Philosophy, 12: 539 - 555.

Barrett, Scott. 2012. 'Credible Commitments, Focal Points, and Tipping.' In Climate Change and Common Sense: Essays in Honour of Tom Schelling, Robert W. Hahn and Alistair Ulph (eds.) Oxford: Oxford University Press.

Barrett, Scott and Robert Stavins. 2003. 'Increasing Participation and Compliance in International Climate Change Agreements.' International Environmental Agreements: Politics, Law, and Economics 3: 349 - 376.

Beitz, Charles R. 1979. Political Theory and International Relations. Princeton: Princeton University Press.

Brennan, Geoffrey and Philip Pettit. 2004. The Economy of Esteem. Oxford: Oxford University Press.

Brock, Gillian. 2009. Global Justice: A Cosmopolitan Account. Oxford: Oxford University Press.

Brölmann, Catherine. 2005. 'Law-Making Treaties: Form and Function in International Law.' Nordic Journal of International Law, Vol. 74 No. 3: 383 - 403. 
Brown, Chris, Terry Nardin, and Nicholas Renegger (eds). 2002. International Relations in Political Thought: Texts from the Ancient Greeks to the First World War. Cambridge: Cambridge University Press.

Buss, Sarah. 1999.'Appearing Respectful: The Moral Significance of Manners.' Ethics. Vol. 109, No. 4: $795-826$.

Bynkershoek, Cornelius van. 2002. 'Selections from “On Questions of Public Law”'. In International Relations in Political Thought: Texts from the Ancient Greeks to the First World War, Chris Brown, Terry Nardin, and Nicholas Renegger (eds.) Cambridge: Cambridge University Press.

Carty, Antony. 2003. 'Scandinavian Realism and Phenomenological Approaches to Statehood and General Custom in International Law'. European Journal of International Law. Vol. 14, No. 4: 817 - 841.

Chayes, Abram, and Chayes, Antonia. 1995. The New Sovereignty: Compliance with International Regulatory Agreements. Cambridge: Harvard University Press.

Coady, C.A.J. 2008. Messy Morality: The Challenge of Politics. Oxford: Oxford University Press.

Cohen, Marshall. 1984. 'Moral Skepticism and International Relations.' Philosophy and Public Affairs Vol. 13, No. 4: 299 - 346.

Cohon, Rachel. 2006. 'Hume on Promises and the Peculiar Act of the Mind.' Journal of the History of Philosophy. Vol. 44, No. 1: 25 - 45.

Davies, Michael. 2006. 'Heavenly Philosophy: What Thomas Hobbes Said to Jean Hampton'. Social Theory and Practice Vol. 32, No. 3:341 - 346. 
Donnelly, Jack. 2000. Realism and International Relations. Cambridge: Cambridge University Press.

Doyle, Michael. 1983. 'Kant, Liberal Legacies, and Foreign Affairs, Part 1.' Philosophy and Public Affairs, 12: 205 - 235.

Dworkin, Ronald. 2011. Justice For Hedgehogs. Cambridge, MA: Harvard University Press.

Eliot, George. 1998. Middlemarch. David Carroll (ed.) New York: Oxford University Press. Ellin, Joseph. 1988. 'Hume on the Morality of Princes.' Hume Studies Vol. 14, No. 1: 111 160.

Erskine, Toni. 2003. ' Assigning Responsibilities to Institutional Moral Agents: The Case of States and 'Quasi-States”. In Can Institutions Have Responsibilities? Collective Moral Agency and International Relations, Toni Erskine (ed.). Basingstoke: Palgrave Macmillan.

Fessler, Daniel, and Katinka Quintellier. 2013. 'Suicide Bombers, Weddings, and Prison Tattoos: An Evolutionary Perspective on Subjective Commitment and Objective Commitment'. In Cooperation and its Evolution, Kim Sterelny, Richard Joyce, Brett Calcott, and Ben Fraser (eds.). Cambridge, MA: The MIT Press.

Finnis, John. 1986. Natural Law and Natural Rights. Oxford: Clarendon Press.

Fitzmaurice, Sir Gerald. 1957. Second Report on the Law of Treaties. UN Doc. A/CN.4/107, YILC, Vol. II.

- $\quad$ 1958. Third Report on the Law of Treaties. UN Doc. A/CN.4/115, YILC, Vol. II. 
Franck, Thomas M. 1990. The Power of Legitimacy Among Nations. New York: Oxford University Press.

French, Peter A. 1984. Collective and Corporate Responsibility. New York: Columbia University Press.

Fried, Charles. 1981. Contract as Promise: A Theory of Contractual Obligation. Cambridge, MA: Harvard University Press.

Friedman, David. N.d. 'A Positive Explanation of Virtue'. Available online at http://www.daviddfriedman.com/Libertarian/Virtue1.html (last accessed $15 / 09 / 2014)$.

Ganz, Melissa. 2008. 'Binding the Will: George Eliot and the Practice of Promising'. ELH, Vol. 75, No. 3: $565-602$.

Gauthier, David. 1970. 'Morality and Advantage'. In Morality and Rational Self-interest, David Gauthier (ed.) Englewood Cliffs: Prentice-Hall.

- 1990a. 'The Unity of Reason: A Subversive Reinterpretation of Kant'. In Moral Dealing: Contract, Ethics, and Reason. Ithaca: Cornell University Press.

- 1990b. 'David Hume, Contractarian'. In Moral Dealing: Contract, Ethics, and Reason. Ithaca: Cornell University Press.

- $\quad$ 1992. 'Artificial Virtues and the Sensible Knave'. Hume Studies Vol. 18, No. 2: 401 $-428$.

Gilbert, Margaret. 1993. 'Is an Agreement an Exchange of Promises?' The Journal of Philosophy Vol. 90, No. 12: 627 - 649. 
- 1996. Living Together: Rationality, Sociality, and Obligation. Lanham: Rowman \& Littlefield Publishers, Inc.

- $\quad$ 1999. 'Obligation and Joint Commitment.' Utilitas. Vol. 11 no. 2: 143 - 146.

Goodin, Robert E. 2000. 'Waitangi Tales'. Australasian Journal of Philosophy. Vol. 78, No. 3: $309-333$.

Grieco, Joseph. 1988. 'Anarchy and the Limits of Cooperation: A Realist Critique of the New Liberal Internationalism. International Organization. Vol. 42 No. 3: 485 - 507.

Grotius, Hugo. 2005. The Rights of War and Peace. Richard Tuck (ed.), from the edition by Jean Barbeyrac. Indianapolis: Liberty Fund.

Guzman, Andrew. T. 2008. How International Law Works: A Rational Choice Theory. Oxford: Oxford University Press.

Haakonssen, Knud. 1981. The Science of a Legislator: The Natural Jurisprudence of David Hume and Adam Smith. Cambridge: Cambridge University Press.

Habib, Allen. 2014. 'Promises'. Stanford Encyclopedia of Philosophy. Available online at http://plato.stanford.edu/entries/promises/ (accessed 19/09/2014).

Hampshire, Stuart. 1978. 'Morality and Pessimism.' ' In Public and Private Morality, Stuart Hampshire (ed.) Cambridge: Cambridge University Press.

Hardin, Russell. 2007. David Hume: Moral and Political Theorist. Oxford: Oxford University Press.

Hare, R.M. 1965. Freedom and Reason. Oxford: Clarendon Press. 
Harris, D. J. 1991. Cases and Materials on International Law, $4^{\text {th }}$ edn. London: Sweet and Maxwell.

Harrison, Jonathan. 1981. Hume's Theory of Justice. Oxford: Oxford University Press.

Hausman, Daniel M. and Michael S. McPherson. 2006. Economic Analysis, Moral Philosophy, and Public Policy, $2^{\text {nd }}$ ed. Cambridge: Cambridge University Press.

Heath, Joseph. 2001. The Efficient Society: Why Canada is as close to utopia as it gets. Toronto: Penguin Books.

Hobbes, Thomas. 1965. Leviathan. London: Everyman.

Hoffman, Stanley. 1998. World Disorders: Troubled Peace in the Cold-War Era. Lanham: Rowman \& Littlefield Publishers, Inc.

Holmes, Robert. 1963. 'On Generalization'. The Journal of Philosophy. Vol. 60, No. 12: 317 $-323$.

Hooker, Brad. 2000. Ideal Code, Real World. Oxford: Oxford University Press.

Hume, David. 1983. History of England: From the Invasion of Julius Caesar to the Revolution in 1688, 6 vols. Indianapolis: Liberty Classics.

- $\quad$ 1987. A Treatise of Human Nature, L.A. Selby-Bigge and P.H. Nidditch (eds.), $2^{\text {nd }}$ edn. Oxford: Oxford University Press. Cited in the text as T followed by book, part, section, and page numbers.

- 1987a. 'Of the Jealousy of Trade.' In David Hume: Essays Moral, Political, and Literary, Eugene F. Miller (ed.), revised edn. Indianapolis: Liberty Classics: 327 331. 
- 1987b. 'Of the Populousness of Ancient Nations.' In David Hume: Essays Moral, Political, and Literary, Eugene F. Miller (ed.), revised edn. Liberty Classics: 377 464.

- 1987c. 'Variant Readings to part 1 - Of the Rise and Progress of the Arts and Sciences.' In David Hume: Essays Moral, Political, and Literary, Eugene F. Miller (ed.), revised edn. Indianapolis: Liberty Classics: 623 - 627.

- $\quad$ 1987d. 'Of Some Remarkable Customs.' In David Hume: Essays Moral, Political, and Literary, Eugene F. Miller (ed.), revised edn. Indianapolis: Liberty Classics:366 376.

- 1987e. 'Of Public Credit'. ' In David Hume: Essays Moral, Political, and Literary, Eugene F. Miller (ed.), revised edn. Indianapolis: Liberty Classics: 349 - 365.

- $\quad$ 1987f. 'Idea of a Perfect Commonwealth.' ' In David Hume: Essays Moral, Political, and Literary, Eugene F. Miller (ed.), revised edn. Indianapolis: Liberty Classics: 512 - 529. In David Hume: Essays Moral, Political, and Literary, Eugene F. Miller (ed.), revised edn. Indianapolis: Liberty Classics: $42-46$.

- 1987g. 'Of the Independency of Parliament'. In David Hume: Essays Moral, Political, and Literary, Eugene F. Miller (ed.), revised edn. Indianapolis: Liberty Classics: 42 $-46$.

- 1987h. 'Whether the British Government inclines more to Absolute Monarchy, or to a Republic.' In David Hume: Essays Moral, Political, and Literary, Eugene F. Miller (ed.), revised edn. Indianapolis: Liberty Classics: 47 - 53.

- 1988. An Enquiry Concerning the Principles of Morals. In Hume, Enquiries, L.A. Selby-Bigge and P.H. Nidditch (eds.) 3 $3^{\text {rd }}$ edn. Oxford: Oxford University Press. Cited in the text as EPM followed by section and marginal section numbers. 
Iida, Keisuke. 1993. 'Analytic Uncertainty and International Cooperation: Theory and Application to International Economic Policy Coordination.' International Studies Quarterly. Vol. 37 no. 4: 431 - 457.

Jarvis, Daryl S. L. 2011. 'Theorizing Risk and Uncertainty in International Relations: The Contributions of Frank Knight.' International Relations. 25: 296 - 312.

Jeffery, Renee. 2009. 'Moral Sentiment and the International Thought of David Hume'. In British International Thinkers from Hobbes to Namier, Ian Hall and Lisa Hill (eds.). New York: Palgrave Macmillan.

Jervis, Robert. 1976. Perception and Misperception in International Politics. Princeton: Princeton University Press.

Kant, Immanuel. 1963. 'Perpetual Peace.' In Kant on History, Lewis White Beck (ed. and trans.) Indianapolis: The Bobbs-Merrill Company, Inc. 85 - 128.

- 2012. Groundwork of the Metaphysics of Morals. Mary Gregor and Jens Timmermann (trans.). Cambridge: Cambridge University Press.

Kavka, Gregory S. 1986. Hobbesian Moral and Political Theory. Princeton: Princeton University Press.

- 1995. 'The Rationality of Rule-following: Hobbes's dispute with the Foole.' Law and Philosophy. Vol. 14 no. 1: 5 - 34 .

Kennan, George F. 1985/6. 'Morality and Foreign Policy.' Foreign Affairs 63 (Winter): $205-218$.

Keohane, Robert O. and Joseph S. Nye. 2001. Power and Independence: World Politics In Transition $3^{\text {rd }}$ edn. New York: Longman. 
Kimel, Dori. 2003. From Promise to Contract: Towards a Liberal Theory of Contract. Hart Publishing.

Klabbers, Jans. 1998. The Concept of Treaty in International Law. The Hague: Kluwer Law International.

- 2004. 'On Human Rights Treaties, Contractual Conceptions and Reservations.' In Reservations to Human Rights Treaties and the Vienna Convention Regime: Conflict, Harmony or Reconciliation, Ineta Ziemele (ed.) Leiden: Martinus Nijhoff.

Kolodny, Niko and R. Jay Wallace. 2003. 'Promises and Practices Revisited.' Philosophy and Public Affairs, Vol. 31, No. 2: 119 - 154.

Koskenniemi, Martti. 2010. 'International Law and raison d'etat: Rethinking the Prehistory of International Law'. In The Roman Foundations of the Law of Nations: Alberico Gentili and the Justice of Empire, Benedict Kingsbury and Benjamin Straumann (eds.) Oxford: Oxford University Press.

Kydd, Andrew. 1997. 'Sheep in Sheep's Clothing: Why Security Seekers Do Not Fight Each Other.' Security Studies. 7: $114-154$.

- 2000. 'Trust, Reassurance, and Cooperation.' International Organization. Vol. 54 No. 2: $325-357$.

Kymlicka, Will. 1995. Multicultural Citizenship. Oxford: Oxford University Press.

Labs, Eric J. 1997. 'Beyond Victory: Offensive Realism and the Expansion of War Aims.' Security Studies 6: 1 - 49.

Lewis, David. 1969. Convention: A Philosophical Study. Cambridge, MA: Harvard University Press. 
List, Christian and Philip Pettit. 2011. Group Agency: The Possibility, Design, and Status of Corporate Agents. Oxford: Oxford University Press.

Locke, John. 1764. Two Treaties of Government. Thomas Hill (ed.). London: A. Millar et al. Machiavelli, Niccolo. 1988. The Prince. Quentin Skinner and Russell Price (eds.). Cambridge: Cambridge University Press.

Mackie, J.L. 1980. Hume's Moral Theory. London: Routledge \& Kegan Paul.

MacCormick, Neil. 1972. 'Voluntary Obligations ad Normative Powers I'. Proceedings of the Aristotelian Society (Supplement). Vol.46: 59 - 78.

Marmor, Andrei. 2009. Social Conventions: From Language to Law. New Jersey: Princeton University Press.

Martinech, A.P. 2005. Hobbes. New York: Routledge.

Mason, Elinor. 2005. 'We Make No Promises.' Philosophical Studies. 123: 33 - 46.

Mastanduno, Michael. 1991. ‘Do Relative Gains Matter? America’s Response to Japanese Industrial Policy.' International Security 21 (Spring): 49 - 88.

McNair, Arnold. 1961. The Law of Treaties. Oxford: Oxford University Press.

Mearsheimer, John J. 1990. 'Back to the Future: Instability in Europe After the Cold War.' International Security 15 (Summer): 5 - 56.

- 1994/5. 'The False Promise of International Institutions.' International Security Vol. 19, No. 3: 5 - 49 .

- $\quad$ 1995. 'A Realist Reply'. International Security. Vol. 20, No. 1: 82 - 93.

- 2001. The Tragedy of Great Power Politics. New York: Norton. 
- 2011. 'Realists as Idealists'. Security Studies 20: 424 - 430.

Melden, A.I. 1977. Rights and Persons. Los Angeles: University of California Press.

Mill, John Stuart. 1969. 'Utilitarianism.' In Collected Works of John Stuart Mill, vol. 10, J.M. Robson, ed. Toronto: University of Toronto Press.

Miller, David. 2004. 'Holding Nations Responsible.' Ethics. 114: 240 - 268.

- 2007. National Responsibility and Global Justice. Oxford: Oxford University Press.

Mintoff, Joe. 2004. 'Is an Agreement an Exchange of Intentions?' Pacific Philosophical Quarterly Vol. 85, No. 1: $44-67$.

Morgenthau, Hans. 1951. In Defense of the National Interest: A Critical Examination of American Foreign Policy. New York: Alfred A. Knopf.

- $\quad$ 1954. Politics Among Nations: The Struggle for Power and Peace, $2^{\text {nd }}$ edn. New York: Alfred A. Knopf.

- $\quad$ 1962a. Politics in the Twentieth Century, Vol. I: The Decline of Democratic Politics. Chicago: University of Chicago Press.

- 1962b. Politics in the Twentieth Century, Vol. III: The Restoration of American Politics. Chicago: University of Chicago Press.

Muniz-Fraticelli, Victor. 2009. 'The Problem of a Perpetual Constitution'. In Intergenerational Justice. Axel Gosseries and Lukas H. Meyer (eds.). Oxford: Oxford University Press.

Nardin, Terry. 1983. Law, Morality, and the Relations of States. New Jersey: Princeton University Press. 
Narveson, Jan. 2007. 'Social Contract, Game Theory and Liberty: Responding to my Critics'. In Liberty, Games and Contracts: Jan Narveson and the Defence of Libertarianism, Malcolm Murray, (ed). Aldershot: Ashgate Publishing Limited.

Norcross, Alastair. 2011. 'Act-Utilitarianism and Promissory Obligation'. In Promises and Agreements: Philosophical Essays, Hanoch Sheinman, ed. Oxford: Oxford University Press.

Nozick, Robert. 1969.'Coercion'. In Philosophy, Science, and Method: Essays in Honor of Ernest Nagel, Sidney Morgenbesser, Patrick Suppes, and Morton Whites, eds. New York: St. Martin's Press, $440-472$.

0’Connell, Mary Ellen. 2008. The Power and Purpose of International Law: Insights from the Theory and Practice of Enforcement. Oxford: Oxford University Press.

O’Neill, Onora. 1986. 'Who Can Endeavour Peace?' Canadian Journal of Philosophy, Vol. 16, Special Issue, Supplementary Vol. 12: Nuclear Weapons, Deterrence and Disarmament: $41-73$.

Oppenheim, Felix E. 2002. 'Foreign Policy, Rationality and Morality.' Ratio Juris. Vol. 15. No. $1: 1-15$.

Osgood, Robert E. and Robert W. Tucker. 1967. Force, Order, and Justice. Baltimore: Johns Hopkins University Press.

Otsuka, Michael. 2003. Libertarianism Without Inequality. Oxford: Oxford University Press.

Oye, Kenneth A., ed. 1986. Cooperation Under Anarchy. Princeton: Princeton University Press. 
Pauwelyn, Joost. 2003. 'A Typology of Multilateral Treaty Obligations: Are WTO Obligations Bilateral or Collective in Nature?' EJIL, Vol. 14, No. 5: 907 - 951.

Pettit, Philip. 1986. 'Free Riding and Foul Dealing'. The Journal of Philosophy, Vol. 83, No. $7: 361-379$.

- 2001. A Theory of Freedom: From the Psychology to the Politics of Agency. Oxford: Oxford University Press.

Pink, Thomas. 2009. 'Promising and Obligation'. Philosophical Perspectives, Vol. 23, No. 1: $389-420$.

Pogge, Thomas. 2002. World Poverty and Human Rights. Cambridge: Polity Press.

- 2008. 'Cosmopolitanism and Sovereignty'. In The Global Justice Reader, Thom Brooks (ed.) Malden, MA: Blackwell.

Pratt, Michael G. 2007. 'Promises, Contracts and Voluntary Obligations'. Law and Philosophy 26: $531-574$.

Prichard, H.A. 2002. 'The Obligation to Keep a Promise.' In Moral Writings, J. MacAdam (ed.) Oxford: Clarendon: 257 - 265.

Pufendorf, Samuel. 2005. Of the Law of Nature and Nations, $4^{\text {th }}$ edn. Basil Kennett (trans) and Jean Barbeyrac (ed). The Lawbook Exchange, Ltd.

Rawls, John. 1955. 'Two Concepts of Rules.' The Philosophical Review Vol. 64, No. 1: 3 32.

- 1971. A Theory of Justice. Oxford: Clarendon. 
- 1999. The Law of Peoples with The Idea of Public Reason Revisited. Cambridge, MA: Harvard University Press.

Raz, Joseph. 1972. 'Voluntary Obligations and Normative Powers - II.' Proceedings of the Aristotelian Society, 46 (suppl): $79-102$.

- $\quad$ 1977. 'Promises and Obligations'. In Law, Morality, and Society: Essays in Honour of H.L.A. Hart, P.M.S. Hacker and Joseph Raz (eds.) Oxford: Oxford University Press. - $\quad$ 1982. 'Promises in Morality and Law.' Harvard Law Review, 95: 916 - 938.

- 1986. The Morality of Freedom. Oxford: Oxford University Press.

- 2011. 'Is There a Reason to Keep a Promise?' King's College London Dickson Poon School of Law Legal Studies Research Paper Series. Paper no. 2014 - 5.

Robertson, Geoffrey. 2006. Crimes Against Humanity. London: Penguin Books.

Runciman, David. 2003. 'Moral Responsibility and the Problem of Representing the State'. In Can Institutions Have Responsibilities? Collective Moral Agency and International Relations, Toni Erskine (ed.). Basingstoke: Palgrave Macmillan.

Sabl, Andrew. 2012. Hume's Politics: Coordination and Crises in the History of England. Princeton: Princeton University Press.

Sandel, Michael. 2012. What Money Can't Buy: The Moral Limits of Markets. Farrar, Strauss and Giroux.

Scanlon, T.M. 1998. What We Owe to Each Other. Cambridge, MA: Harvard University Press.

Schelling, T.C. 1960. The Strategy of Conflict. Cambridge, MA: Harvard University Press.

- $\quad$ 1966. Arms and Influence. New Haven: Yale University Press. 
Schwartz, Daniel. 2012. 'The Justice of Peace Treaties'. The Journal of Political Philosophy, Vol. 20, No. 3: 273 - 292.

Schwarzenberger, Georg. 1951. Power Politics: A Study of International Society, $2^{\text {nd }}$ edn. London: J. Cape.

Searle, John R. 2001. Rationality in Action. Cambridge, MA: MIT Press.

Seidler, Michael. 2013. 'Pufendorf's Moral and Political Philosophy'. Stanford Encyclopedia of Philosophy. Available online at http://plato.stanford.edu/entries/pufendorf-moral/, accessed 15/06/2014.

Sheinman, Hanoch. 2008. 'Promise as Practice Reason.' Acta Analytica. Vol. 23 No. 4: 287 $-318$.

- 2011a. 'Agreement as Joint Promise.' In Promising and Agreements: Philosophical Essays, Hanoch Sheinman (ed.). Oxford: Oxford University Press.

- 2011b. 'The Conventionality of Promising: A Defence.' Jurisprudence. Vol. 2 No. 2: $463-492$.

- 2011c. 'Introduction: Promises and Agreements'. In Promising and Agreements: Philosophical Essays, Hanoch Sheinman (ed.). Oxford: Oxford University Press.

Shiffrin, Seana. 2008. 'Promising, Intimate Relationships, and Conventionalism.' Philosophical Review. Vol. 117, No. 4: 481 - 524.

Simmonds, N.E. 2004. 'Review of From Promise to Contract.' Cambridge Law Journal Vol. 63, No. 2: $507-510$.

Skyrms, Brian. 1996. Evolution of the Social Contract. Cambridge: Cambridge University Press. 
- 2010. Signals: Evolution, Learning, and Information. Oxford: Oxford University Press.

Smith, Stephen. 2004. Contract Theory. Oxford: Oxford University Press.

Springford, John, Simon Tilford, and Philip White. 2014. The Economic Consequences of Leaving the EU: The Final Report of the CER Commission on the UK and the EU's Single Market. Centre For European Reform. Available at http://www.cer.org.uk/sites/default/files/publications/attachments/pdf/2014/report _smc_final_report_june2014-9013.pdf.

Teson, Fernando. R. 1998. A Philosophy of International Law. Westview Press.

Tomz, Michael. 2007. Reputation and International Cooperation: Sovereign Debt Across Three Centuries. Princeton: Princeton University Press.

Thompson, Janna. 2002. Taking Responsibility for the Past: Reparation and Historical Injustice. Cambridge: Polity.

Tuck, Richard. 1999. The Rights of War and Peace: Political Thought and the International Order from Grotius to Kant. Oxford: Oxford University Press.

Van de Haar, Edwin. 2008. 'David Hume and International Political Theory: A Reappraisal'. Review of International Studies. Vol. 34, No. 2: 225 - 242.

Vattel, Emer de. 2008. The Law of Nations. B. Kapossy and R. Whatmore (eds.) Indianapolis: Liberty Fund.

Waldron, Jeremy. 1992. 'Superseding Historic Injustice'. Ethics. Vol. 103, No. 1: 4 - 28. 
- 2005. 'The Half-Life of Treaties: Waitangi, Rebus Sic Stantibus'. Otago Law Review. Vol. 11, No. 2: $161-182$.

- 2011. 'A Religious View of the Foundations of International Law'. Public Law \& Legal Theory Research Paper Series, Working Paper No. 11 - 29.

Walt, Stephen M. 1998. 'International Relations: One World, Many Theories.' Foreign Policy 110: $29-46$.

Waltz, Kenneth. 1979. Theory of International Politics. New York: Random House.

- 1988. 'The Origins of War in Neorealist Theory.' The Journal of Interdisciplinary History. Vo. 18 No. 4: $615-628$.

- $\quad$ 1996. 'International Politics is not Foreign Policy.' Security Studies 6: 54 - 57.

- 1997. 'Evaluating theories.' American Political Science Review 91 (Dec): 913 - 917.

Walzer, Michael. 1977. Just and Unjust Wars. New York: Basic Books.

Wehberg. Hans. 1959. 'Pacta sunt servanda'. American Journal of International Law. Vol. 53, No. 4: $775-786$.

Wenger, Andreas, Christian Nuenlist, and Anna Locher (eds.). 2007, Transforming NATO in the Cold War: Challenges beyond deterrence in the 1960s. Abingdon: Routledge.

Whelan, Frederick. 2004. Hume and Machiavelli: Political Realism and Liberal Thought. Lanham: Lexington Books.

Williams, Bernard. 1978. 'Politics and Moral Character.' In Public and Private Morality, Stuart Hampshire (ed.) Cambridge: Cambridge University Press.

The Bible: Authorized King James Version with Apocrypha. 2008. R Carroll and S Prickett (eds.) Oxford: Oxford University Press. 


\section{Reports of the International Court of Justice}

ICJ Reports: South-West Africa Cases (Second Phase), (Ethiopia v. South Africa; Liberia v. South Africa) (1966).

Dissenting Opinion of Judge Alvarez to ICJ Reports: Reservations to the Convention on the Prevention and Punishment of the Crime of Genocide Advisory Opinion (1951). 